\begin{abstract}
UNIVERSIDADE DE SÃO PAULO
ESCOLA DE ENGENHARIA DE SÃO CARLOS

CENTRO DE RECURSOS HÍDRICOS E ESTUDOS AMBIENTAIS

PROGRAMA DE PÓS-GRADUAÇÃO EM CIÊNCIAS DA ENGENHARIA AMBIENTAL
\end{abstract}

PAULO PONCE ARROIO JUNIOR

\title{
APRIMORAMENTO DAS ROTINAS E PARÂMETROS DOS PROCESSOS HIDROLÓGICOS DO MODELO COMPUTACIONAL SOIL AND WATER ASSESSMENT TOOL - SWAT
}

São Carlos - SP

2016 

PAULO PONCE ARROIO JUNIOR

\section{APRIMORAMENTO DAS ROTINAS E PARÂMETROS DOS PROCESSOS HIDROLÓGICOS DO MODELO COMPUTACIONAL SOIL AND WATER ASSESSMENT TOOL - SWAT}

Tese apresentada à Escola de Engenharia de São Carlos, da Universidade de São Paulo, como parte dos requisitos para obtenção do título de doutor em Ciências da Engenharia Ambiental.

Orientador: Prof. Dr. Frederico Fábio Mauad

São Carlos - SP

2016 
AUTORIZO A REPRODUÇÃO TOTAL OU PARCIAL DESTE TRABALHO, POR QUALQUER MEIO CONVENCIONAL OU ELETRÔNICO, PARA FINS DE ESTUDO E PESQUISA, DESDE QUE CITADA A FONTE.

Arroio Junior, Paulo Ponce

Aprimoramento das rotinas e parâmetros dos processos hidrológicos do modelo computacional soil and Water Assessment Tool - SWAT / Paulo Ponce Arroio Junior; orientador Frederico Fábio Mauad. São Carlos, 2016.

Tese (Doutorado) - Programa de Pós-Graduação e Área de Concentração em Ciências da Engenharia Ambiental -Escola de Engenharia de São Carlos da Universidade de São Paulo, 2016.

1. SWAT. 2. Evapotranspiração. 3. Balanço hídrico. 4. Vazão. I. Título. 


\section{FOLHA DE JULGAMENTO}

Candidato: Engenheiro PAULO PONCE ARROIO JUNIOR.

Título da tese: "Aprimoramento das rotinas e parâmetros dos processos hidrológicos do modelo computacional Soil and Water | Assessment Tool - SWAT".

Data da defesa: 14/12/2016.

Comissão Julgadora:

Prof. Associado Frederico Fábio Mauad

(Orientador)

(Escola de Engenharia de São Carlos/EESC)

Prof. Titular Edson Cezar Wendland

(Escola de Engenharia de São Carlos/EESC)

Dr. Silvio Crestana

(EMBRAPA)

Dr. Julio Cesar Pascale Palhares

(EMBRAPA)

Prof. Dr. Ricardo Tezini Minoti

(Universidade de Brasília/UnB)
Resultado:
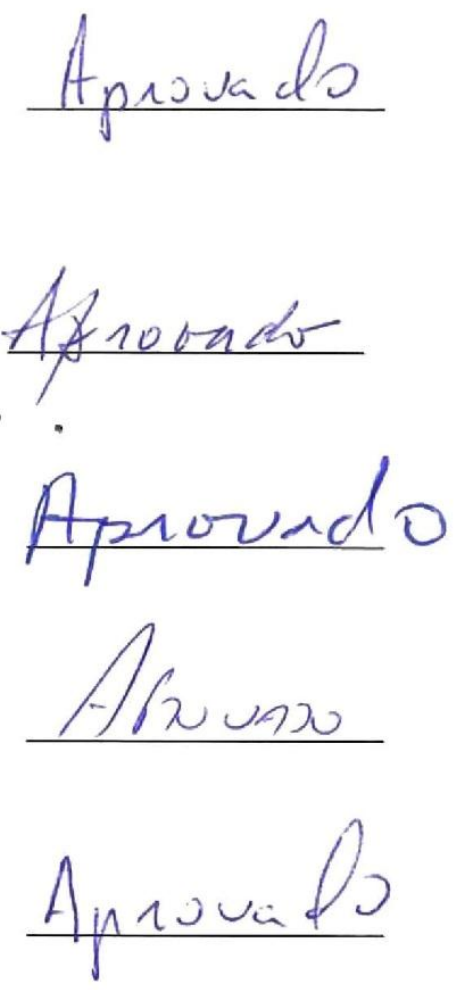

Coordenador do Programa de Pós-Graduação em Ciências da Engenharia Ambiental:

Prof. Associado Frederico Fabio Mauad

Presidente da Comissão de Pós-Graduação:

Prof. Associado Luis Fernando Costa Alberto 

Dedico este trabalho aos meus pais Paulo e Rosimara, que sempre me deram apoio e incentivo em todas as etapas da minha vida. 



\section{AGRADECIMENTOS}

À minha família, pela dedicação, compreensão e paciência que tiveram durante todo este tempo e que, mesmo a distância, sempre me apoiou em todos os caminhos e decisões.

Ao Prof. Dr. Frederico Fábio Mauad, pela orientação.

À Coordenação de Aperfeiçoamento de Pessoal de Nível Superior - CAPES, pela bolsa de doutorado fornecida.

Aos amigos João Villela e Gustavo Scarpinella, pelo fornecimento de mapeamentos e informações necessárias à realização deste trabalho.

Aos companheiros de pesquisa do Núcleo de Hidrometria Renato, Bruno, Dalva, Fran, Cláudio, Ailton, Júlio e Marcus, por todas as dicas, auxílios e momentos divididos durante a realização deste trabalho.

Ao Centro de Recursos Hídricos e Estudos Ambientais (CRHEA), pela oportunidade de realização desta pesquisa e em especial aos funcionários Nelson, Zé Luiz, Cidão, Regina, Betão e Miro, pelo suporte no desenvolvimento das atividades.

A todas as outras pessoas que não foram citadas aqui, mas que de alguma forma colaboraram com este trabalho. 



\section{RESUMO}

ARROIO JUNIOR, P. P. Aprimoramento das rotinas e parâmetros dos processos hidrológicos do modelo computacional Soil and Water Assessment Tool - SWAT. 152 p. Tese (Doutorado em Ciências da Engenharia Ambiental) - Escola de Engenharia de São Carlos, Universidade de São Paulo, São Carlos, 2016.

O modelo Soil and Water Assessment Tool (SWAT) tem sido utilizado para avaliar os impactos do uso e manejo da terra nos recursos hídricos, sedimentos e agroquímicos em diversas escalas e condições ambientais em todo o mundo. Entretanto, pelo fato de ter sido desenvolvido em centros de pesquisa norte-americanos, alguns parâmetros e rotinas de simulação não refletem adequadamente determinados processos de bacias localizadas em regiões tropicais. Nesse sentido, o presente trabalho visou aprimorar a modelagem hidrológica do SWAT através da revisão e modificação de processos relacionados à simulação da evapotranspiração. Os procedimentos propostos incluíram a alteração das rotinas de dormência vegetal no código fonte do modelo e a modificação dos cronogramas de operações de manejo e parâmetros do banco de dados de crescimento das plantas, visando reproduzir com maior precisão o ciclo das culturas em bacias tropicais. As modificações foram testadas em cinco bacias localizadas no Estado de São Paulo, com áreas entre 42 e $5.959 \mathrm{~km}^{2}$, sendo comparados os resultados obtidos antes e depois da implementação das mesmas. Com as alterações, a análise do balanço hídrico anual evidenciou um aumento nos valores de evapotranspiração de cerca de $61 \%$ nas bacias, aproximando-se dos totais anuais de evapotranspiração calculados através de métodos empíricos, bem como houve redução significativa do escoamento superficial. Verificou-se uma melhoria da simulação de vazão em todas as bacias, sendo obtidos valores superiores para o Coeficiente de Eficiência de NashSutcliffe (NSE) quando comparados à simulação sem as alterações. A calibração e validação foram realizadas com base na simulação modificada, sendo obtidos valores de NSE mensais entre 0,71 e 0,93 na calibração e 0,53 e 0,88 na validação, enquanto os valores diários de NSE situaramse entre 0,51 e 0,82 na calibração e 0,38 e 0,83 na validação. A calibração a partir de uma simulação na qual as distorções dos processos hidrológicos da bacia estivessem previamente minimizadas resultou em bons resultados sem alteração excessiva dos parâmetros, indicando uma simulação hidrológica de melhor consistência.

Palavras-chave: SWAT, evapotranspiração, balanço hídrico, vazão 



\begin{abstract}
ARROIO JUNIOR, P. P. Improvement of routines and parameters of Soil and Water Assessment Tool hydrological processes. 152 p. Thesis (Doctoral Degree in Environmental Engineering Sciences) - São Carlos School of Engineering, University of São Paulo at São Carlos, 2016.
\end{abstract}

The Soil and Water Assessment Tool (SWAT) has been used to predict the impact of land management practices on water, sediment, and agricultural chemical yields in a wide range of scales and environmental conditions across the globe. However, originally developed in the United States, some parameters and routines are unrealistic for simulating in tropical watersheds. In this sense, this work aims to improve the hydrologic modeling of SWAT model by reviewing and modifying parameters and routines related to evapotranspiration process. In order to adequately represent crop growth in tropical basins, the proposed procedures included changes in dormancy routines of SWAT source code and modifications of scheduled management operations and plant growth database parameters. These modifications were tested in five different basins at São Paulo State, Brazil, with areas ranging from 42 to $5959 \mathrm{~km}^{2}$, by comparing the results before and after their implementation. Annual water balance analysis showed an increase in evapotranspiration about $61 \%$ for basins, approaching the total annual evapotranspiration estimated by empirical methods. Hence, it was observed that surface runoff and base flow components showed a decrease. The modifications resulted in improved flow simulation for all basins, showing better NashSutcliffe Efficiency Coefficient (NSE) values compared to the unchanged simulation. Calibration and validation processes used the modified simulation database, being achieved monthly NSE between $0.71-0.73$ at calibration and $0.53-0.88$ at validation, while daily NSE were $0.51-0.82$ at calibration and $0.38-0.83$ at validation. Overall, minimizing distortions in hydrological processes at pre-calibration step resulted in good estimations without excessive modification of parameters at calibration, attesting a consistent hydrological modeling for the basins analyzed.

Keywords: SWAT, hydrological modelling, water balance, streamflow 



\section{LISTA DE FIGURAS}

Figura 1 - Representação dos processos hidrológicos de uma bacia hidrográfica 7

Figura 2 - Estimativa da evapotranspiração global anual obtida pelo sensor MODIS/AQUAEOS da NASA para o período entre 2000 e 2006

Figura 3 - Localização geográfica das bacias selecionadas neste estudo.

Figura 4 - Caracterização física da bacia do Córrego Cana-do-Reino.

Figura 5 - Caracterização física da bacia do Ribeirão do Feijão.

Figura 6 - Caracterização física da bacia do Ribeirão Mandaguari. 45

Figura 7 - Caracterização física da bacia do Rio Pari. 47

Figura 8 - Caracterização física da bacia do alto Rio Paranapanema.

Figura 9 - Variação na altura do dossel e no índice de área foliar durante o desenvolvimento da planta no modelo SWAT.

Figura 10 - Localização dos postos fluviométricos, pluviométricos e estações meteorológicas utilizadas nas simulações. 78

Figura 11 - Variação anual do índice de área foliar em cinco HRUs de distintos usos da terra da bacia do Ribeirão do Feijão: (a) mata; (b) reflorestamento de eucalipto; (c) pastagem; (d) cana-de-açúcar e (e) culturas agrícolas genéricas.

Figura 12 - Edição do cronograma de operações agrícolas para HRU com cana-de-açúcar.. 85 Figura 13 - Parâmetros relacionados à curva de desenvolvimento do índice de área foliar no SWAT 86

Figura 14 - Janela de edição dos parâmetros do banco de dados de crescimento vegetal ..... 87

Figura 15 - Gráfico comparativo do IAF e da evapotranspiração entre a Simulação Padrão e Modificada em HRU coberta por mata. 100

Figura 16 - Gráfico comparativo do IAF e da evapotranspiração entre a Simulação Padrão e Modificada em HRU coberta por pastagem.

Figura 17 - Gráfico comparativo do IAF e da evapotranspiração entre a Simulação Padrão e Modificada em HRU coberta por plantio de eucalipto. 102

Figura 18 - Gráfico comparativo do IAF e da evapotranspiração entre a Simulação Padrão e Modificada em HRU coberta por cana-de-açúcar. 103

Figura 19 - Gráfico comparativo do IAF e da evapotranspiração entre a Simulação Padrão e Modificada em HRU coberta por cultura agrícola genérica. 104 
Figura 20 - Resposta do índice de área foliar e da evapotranspiração na HRU com cana-deaçúcar: (a) sem a alteração da rotina de dormência vegetal; (b) sem a alteração dos cronogramas de manejo; e (c) sem a alteração dos parâmetros de crescimento vegetal........ 106 Figura 21 - Comparação entre os principais componentes do balanço hídrico anual nas Simulações Padrão e Modificada (precipitação, evapotranspiração real, escoamento superficial, fluxo lateral, recarga para o aquífero raso e fluxo de base) ............................. 108 Figura 22 - Estimativa da evapotranspiração real anual para as cinco bacias obtidas através de métodos empíricos. 109 Figura 23 - Variação sazonal dos valores de evapotranspiração simulados pelo SWAT e estimados empiricamente para a Bacia do Ribeirão do Feijão.

Figura 24 - Comparação entre as estimativas experimentais obtidas para o Ribeirão da Onça e os resultados simulados pelo SWAT para o Ribeirão do Feijão no ano de 2005.

Figura 25 - Vazões observadas e simuladas no posto fluviométrico do Ribeirão do Feijão. (a) Vazão mensal durante a década de 1990. (b) Vazão diária durante o ano de 1995................ 116 Figura 26 - Comparação entre a vazão mensal observada e simulada nos períodos de calibração e validação nos postos: (a) P1, (b) P2, (c) P3, (d) P4-I, (e) P4-II, (f) P5-I, (g) P5-II e (h) P5-III.

Figura 27 - Comparação entre a vazão diária observada e simulada nos períodos de calibração e validação nos postos: (a) P1, (b) P2, (c) P3, (d) P4-I, (e) P4-II, (f) P5-I, (g) P5-II e (h) P5-III. 125 


\section{LISTA DE TABELAS}

Tabela 1 - Comparativo entre as características de alguns modelos hidrológicos aplicáveis em escala de bacia, com a especificação do método de simulação dos principais processos hidrológicos

Tabela 2 - Descrição dos principais arquivos gerais de entrada do modelo SWAT.

Tabela 3 - Recomendações de densidade mínima por tipo de estação para redes

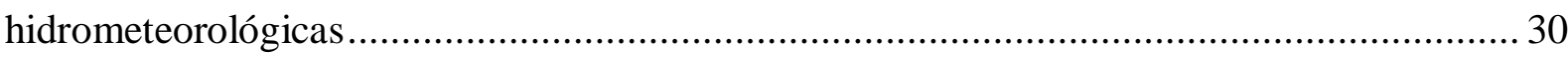

Tabela 4 - Informações gerais sobre as bacias selecionadas neste trabalho. ........................ 40

Tabela 5 - Fontes de obtenção dos dados altimétricos. …............................................... 72

Tabela 6 - Levantamentos pedológicos utilizados nas simulações. ................................... 73

Tabela 7 - Produtos de sensoriamento remoto utilizados. .............................................. 75

Tabela 8 - Associação entre as classes de uso e ocupação do solo da bacia e os tipos de cobertura do solo disponíveis no banco de dados do SWAT. 76

Tabela 9 - Configurações gerais adotadas nas simulações para as bacias de estudo. 79

Tabela 10 - Repartição das séries históricas de vazão coletadas nos postos fluviométricos. . 89

Tabela 11 - Classificação do desempenho para o NSE e PBIAS

Tabela 12 - Alteração dos parâmetros do banco de dados de crescimento das plantas. Entre parênteses encontram-se os valores originais, enquanto os valores logo abaixo indicam o novo valor inserido. 87

Tabela 13 - Valor de K em relação à temperatura média anual........................................ 94

Tabela 14 - Fator de correção $p$ em função da latitude e época do ano ................................97

Tabela 15 - Coeficientes de cultura utilizados na determinação da evapotranspiração real. . 98 Tabela 16 - Estatísticas referentes às simulações de vazão nos postos fluviométricos das bacias obtidos na Simulação Padrão

Tabela 17 - Estatísticas referentes às simulações de vazão nos postos pluviométricos das bacias obtidos na Simulação Modificada

Tabela 18 - Informações gerais sobre o procedimento de calibração das simulações: parâmetros modificados, descrição dos parâmetros, limites máximos e mínimos fixados para alteração e valores ajustados na melhor simulação.

Tabela 19 - Estatísticas de precisão obtidas nos períodos de calibração e validação e classificação do desempenho 
Tabela 20 - Ordenação dos parâmetros utilizados na calibração das cinco bacias em relação

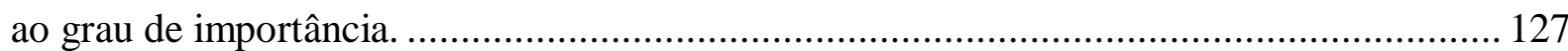

Tabela 21 - Valores de NSE obtidos em simulações de vazão com o SWAT em bacias das regiões sul e sudeste do Brasil. 128 


\section{LISTA DE SÍMBOLOS}

\begin{tabular}{|c|c|}
\hline$A$ & Área da bacia \\
\hline$a_{b c}$ & Coeficiente de ajuste da equação de Blaney-Criddle \\
\hline$a_{t}$ & Coeficiente da equação Thornthwaite \\
\hline$b_{b c}$ & Coeficiente de ajuste da equação de Blaney-Criddle \\
\hline$c l$ & Fator de correção do método da Radiação Solar \\
\hline $\mathrm{CN}$ & Número da curva de escoamento superficial \\
\hline co & Fator de correção do método da Radiação Solar \\
\hline $\operatorname{cov}_{\text {sol }}$ & Índice de cobertura do solo \\
\hline$c_{p}$ & Calor específico do ar úmido numa pressão constante \\
\hline$C V$ & Biomassa e resíduos acima do solo \\
\hline$d$ & Deslocamento do plano zero do perfil do vento \\
\hline$d_{n}$ & Dia juliano ou dia do ano \\
\hline$e$ & Pressão de vapor \\
\hline$E_{0}$ & Fator de correção da excentricidade da órbita da Terra \\
\hline$E_{a}$ & Evapotranspiração real \\
\hline$E_{a}$ & Evapotranspiração real \\
\hline$E_{c a n}$ & Evaporação de água livre dentro do dossel \\
\hline$E L$ & Elevação \\
\hline$e^{o}$ & Pressão de vapor de saturação \\
\hline$E_{o}$ & Evapotranspiração potencial \\
\hline$E_{S}$ & Sublimação máxima/evaporação do solo \\
\hline$E_{\text {soil,z }}$ & Demanda evaporativa na profundidade $z$ \\
\hline$E_{T}$ & Transpiração máxima \\
\hline$F_{C}$ & Fator de correção da equação de Thornthwaite \\
\hline$f r_{g, m x}$ & Fração da condutância estomática máxima \\
\hline$f r_{\text {LAImx }}$ & $\begin{array}{l}\text { Fração do índice máximo da área foliar da planta correspondente a uma fração } \\
\text { atribuída de potenciais unidades de calor para a planta }\end{array}$ \\
\hline$f r_{P H U}$ & $\begin{array}{l}\text { Fração de potenciais unidades de calor acumuladas para a planta em um } \\
\text { determinado dia na fase vegetativa }\end{array}$ \\
\hline$G$ & Densidade do fluxo de calor para o solo \\
\hline$g_{l}$ & Condutância da folha \\
\hline$g_{l, m x}$ & Máxima condutância estomática de uma única folha \\
\hline$H_{0}$ & Irradiação solar extraterrestre \\
\hline$H_{b}$ & Radiação líquida de onda longa \\
\hline$h_{c}$ & Altura média do dossel da planta \\
\hline$h_{c, m x}$ & Altura máxima da copa (dossel) da planta \\
\hline
\end{tabular}




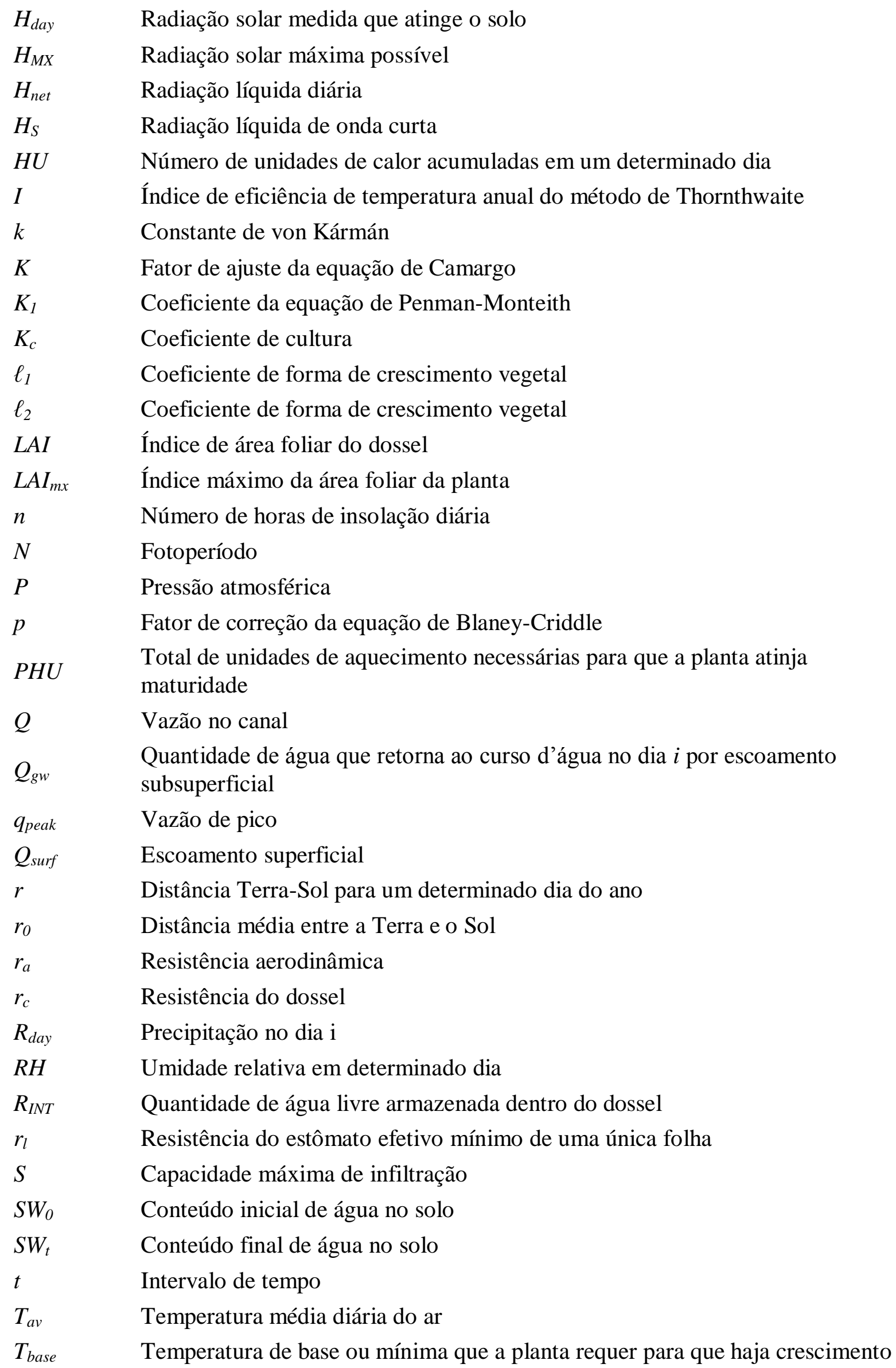




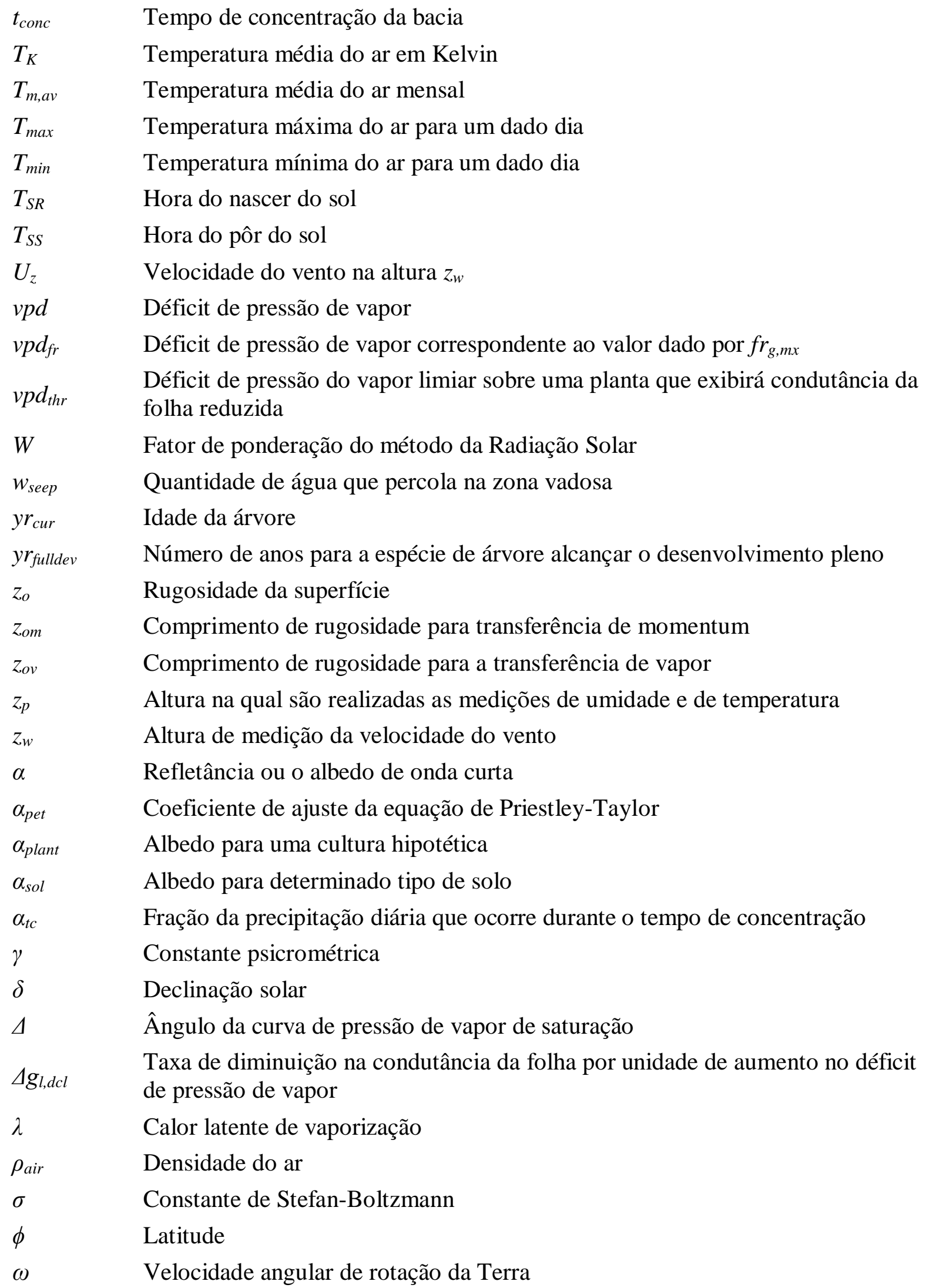




\section{LISTA DE SIGLAS E ABREVIATURAS}

$\begin{array}{ll}\text { AGNPS } & \text { Agricultural Non-Point Source } \\ \text { ANA } & \text { Agência Nacional de Águas } \\ \text { AnnAGNPS } & \text { Annualized Agricultural Non-Point Source } \\ \text { ANSWERS } & \text { Areal Nonpoint Source Watershed Enviroment Response Simulation } \\ \text { BDMEP } & \text { Banco de Dados Meteorológicos para Ensino e Pesquisa } \\ \text { BPM } & \text { Best management practices } \\ \text { CBERS } & \text { Satélite Sino-Brasileiro de Recursos Terrestres } \\ \text { CEAP } & \text { Conservation Effects Assessment Project } \\ \text { CFSR } & \text { Climate Forecast System Reanalysis } \\ \text { CREAMS } & \text { Chemicals, Runoff, and Erosion from Agricultural Management Systems } \\ \text { DAEE } & \text { Departamento de Águas e Energia Elétrica do Estado de São Paulo } \\ \text { EMBRAPA } & \text { Empresa Brasileira de Pesquisa Agropecuária } \\ \text { EMPLASA } & \text { Empresa Paulista de Planejamento Metropolitano } \\ \text { EOS } & \text { Earth Observing System } \\ \text { EPIC } & \text { Erosion Productivity Impact Calculator } \\ \text { ESRI } & \text { Environmental Systems Research Institute } \\ \text { ETo } & \text { Evapotranspiração de referência } \\ \text { ETp } & \text { Evapotranspiração real } \\ \text { ETr } & \text { Evapotranspiração potencial } \\ \text { FAO } & \text { Organização das Nações Unidas para Agricultura e Alimentação } \\ \text { GCM } & \text { Modelos de Circulação Geral } \\ \text { GLEAMS } & \text { Groundwater Loading Effects of Agricultural Management Systems } \\ \text { GLUE } & \text { Generalized Likelihood Uncertainty Estimation } \\ \text { HRU } & \text { Hydrologic Response Units } \\ \text { HUMUS } & \text { Hydrologic Unit Modeling of the United States } \\ \text { IAC } & \text { Instituto Agronômico de Campinas } \\ \text { IAF } & \text { Índice de área foliar } \\ \text { IBGE } & \text { Instituto Brasileiro de Geografia e Estatística } \\ \text { IGC } & \text { Instituto Geográfico e Cartográfico de São Paulo } \\ \text { INMET } & \text { Instituto Nacional de Meteorologia } \\ \text { INPE } & \text { Instituto Nacional de Pesquisas Espaciais } \\ \text { IPCC } & \text { Painel Intergovernamental sobre Mudanças Climáticas } \\ & \end{array}$


IPT Instituto de Pesquisas Tecnológicas

MCMC Markov chain Monte Carlo

MDE Modelo Digital de Elevação

METRIC Mapping EvapoTranspiration at high Resolution with Internalized Calibration

MGB Modelo de Grandes Bacias

MODIS Moderate-Resolution Imaging Spectroradiometer

NASA National Aeronautics and Space Administration

NSE Coeficiente de Eficiência de Nash-Sutcliffe

OMM Organização Mundial de Meteorologia

ParaSol Parameter Solution

PBIAS Percentual de Tendência

$\mathrm{PCH} \quad$ Pequena central hidrelétrica

PSO Particle Swarm Optimization

SCS Serviço de Conservação de Solos

SEBAL Surface Energy Balance Algorithms for Land

SHE Systeme Hydrologique European

SIG Sistema de Informação Geográfica

SRTM Shuttle Radar Topography Mission

SSURGO Soil Survey Geographic

STATSGO State Soil Geographic

SUFI-2 Sequential Uncertainty Fitting Version 2

SWAT Soil and Water Assessment Tool

SWAT-CUP SWAT Calibration and Uncertainty Procedures

SWRRB Simulator for Water Resources in Rural Basins

TIN Triangulated Irregular Network

TOPMODEL Topography-Based Hydrological Model

TOPODATA Banco de Dados Geomorfométricos do Brasil

UA Unidade astronômica

UGRHI Unidade de Gerenciamento de Recursos Hídricos

USDA Departamento de Agricultura dos Estados Unidos

USGS Serviço Geológico dos Estados Unidos 


\section{DESIGINAÇÃO DOS PARÂMETROS DO MODELO SWAT}

ALAI_MIN Índice de área foliar mínimo no período de dormência

ALPHA_BF Fator alfa de recessão do fluxo de base

ALPHA_BNK Fator alpha do fluxo de base para o armazenamento marginal

ANION_EXCL Porosidade do solo

BLAI Índice de área foliar máximo para a planta

CANMX Armazenamento máximo de água no dossel vegetativo

CH_K2 Condutividade hidráulica do canal principal

CH_N2 Coeficiente de Manning para o canal principal

CLAY Porcentagem de argila

CN2 Valor da curva número para a condição de umidade II

DLAI

ESCO Fator de compensação de evaporação do solo

FRGRW1 Fração da fase vegetativa correspondente ao $1^{\circ}$ ponto na curva de desenvolvimento da área foliar

FRGRW2 Fração da fase vegetativa correspondente ao $2^{\circ}$ ponto da curva de desenvolvimento ideal da área foliar

GW_DELAY Intervalo de tempo para recarga do aquífero raso

GW_REVAP Coeficiente de re-evaporação da água do aquífero raso para a zona insaturada

GWQMN Profundidade limite de água no aquífero raso para ocorrer fluxo de retorno no canal

HYDGRP Grupo hidrológico do solo

IGRO Código de status de cobertura do solo

LAI_INIT Índice de área foliar do dossel para espécies transplantadas

LAIMX1 Fração do índice máximo da área foliar da planta correspondente ao $1^{\circ}$ ponto na curva de desenvolvimento ideal da área foliar

LAIMX2 Fração do índice máximo da área foliar da planta correspondente ao $2^{\circ}$ ponto na curva de desenvolvimento ideal da área foliar

LAT_TTIME Tempo para o fluxo lateral atingir o canal

NLAYERS Número de camadas do perfil

REVAPMN Profundidade de água limite no aquífero raso para que ocorra "revap" para a zona insaturada

ROCK Porcentagem de cascalho

SAND Porcentagem de areia 
SILT Porcentagem de silte

SLSUBBSN Comprimento do declive médio

SOL_ALB Albedo do solo

SOL_AWC Capacidade de água disponível no solo

SOL_BD Densidade do solo

SOL_CBN Teor de carbono orgânico

SOL_K Condutividade hidráulica saturada

SOL_Z Profundidade de cada camada do solo

SOL_ZMX Profundidade máxima da raiz no solo

SURLAG Coeficiente de retardo do escoamento superficial

USLE_K Fator K da USLE

W_STRS Número de dias de estresse hídrico 


\section{SUMÁRIO}

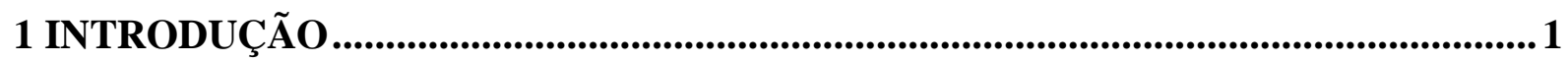

2 OBJETIVOS _.............................................................................................................................

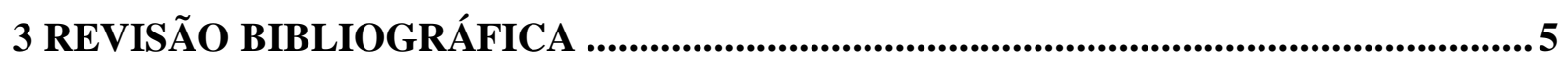

3.1 Balanço hídrico em bacias hidrográficas ............................................................ 5

3.2 Modelos hidrológicos em escala de bacia hidrográfica ........................................ 16

3.3 O modelo SWAT: principais características e panorama geral das aplicações .............21

3.4 O uso do SWAT no Brasil: principais dificuldades e limitações................................. 28

3.4.1 Considerações sobre a disponibilidade, precisão e escala dos dados de entrada

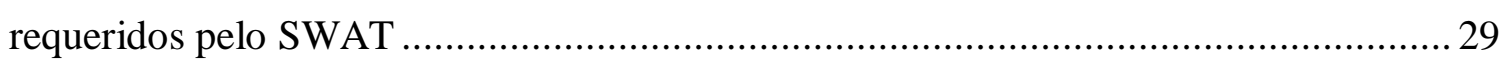

3.4.2 Considerações sobre a disponibilidade de dados para calibração e validação do

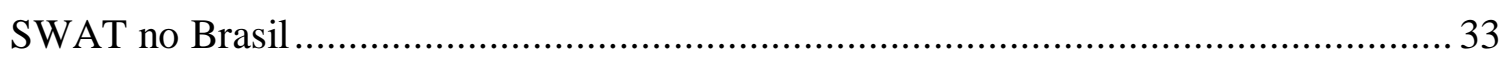

3.4.3 Limitações em alguns dos algoritmos do SWAT para uso em bacias brasileiras ... 34

4 PROCEDIMENTOS METODOLÓGICOS.................................................................... 39

4.1 Descrição das bacias selecionadas para simulação no SWAT ................................... 39

4.2 Descrição geral das rotinas de simulação hidrológica do modelo SWAT .....................50

4.2.1 Evapotranspiração potencial pelo método de Penman-Monteith .......................... 53

4.2.2 Equações relacionadas ao crescimento da planta ............................................. 64

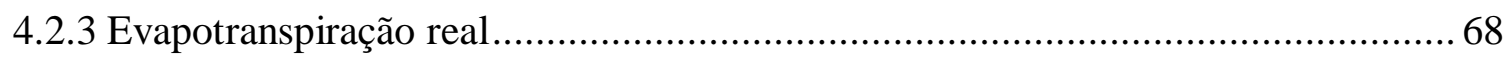

4.3 Dados de entrada e configurações adotadas nas simulações iniciais ......................... 70

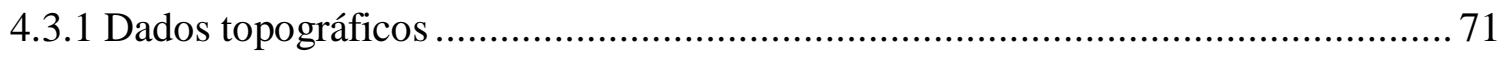

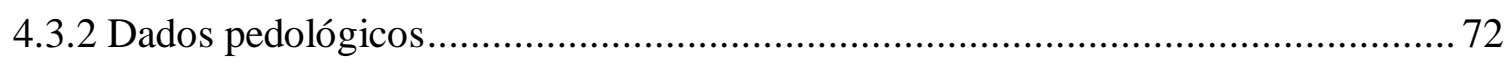

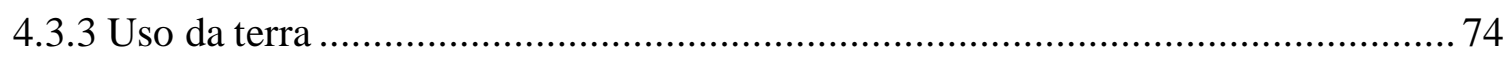

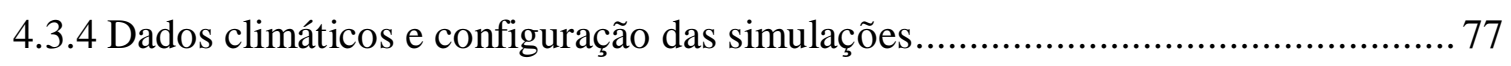

4.4 Modificações visando à melhoria da simulação hidrológica ..................................... 80

4.4.1 Alteração das rotinas de dormência no código fonte do SWAT …….................... 80 
4.4.2 Alteração das operações de manejo 83

4.4.3 Alteração de parâmetros do banco de dados de crescimento das plantas..... 85

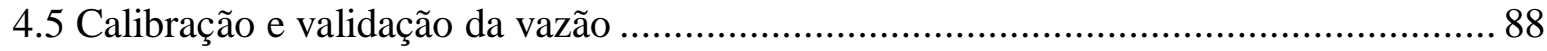

4.6 Métodos empíricos de cálculo da evapotranspiração ............................................. 91

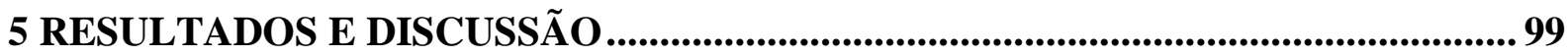

5.1 Evapotranspiração e índice de área foliar nas HRUs ............................................ 99

5.2 Análise dos componentes do balanço hídrico ................................................ 107

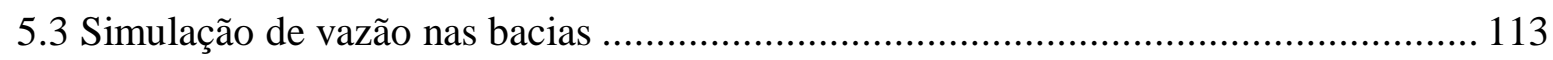

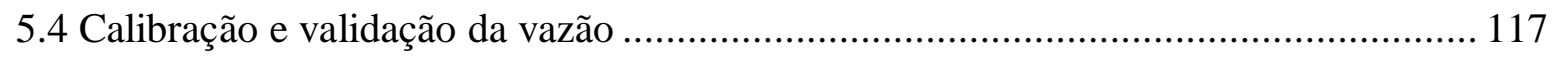

6 CONCLUSÕES E RECOMENDAÇÕES ....................................................... 130

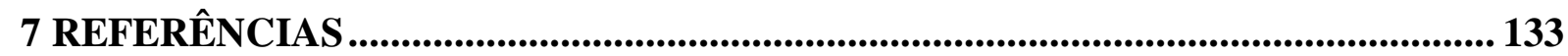

ANEXO I - Modificação das rotinas de dormência no código fonte do SWAT ............. 151 



\section{INTRODUÇÃO}

A caracterização, quantificação e monitoramento dos processos hidrológicos que ocorrem nas bacias hidrográficas é etapa fundamental e imprescindível para compatibilizar a disponibilidade dos recursos hídricos e suas demandas, tanto atuais quanto futuras. A correta compreensão dos componentes do balanço hídrico, bem como dos processos que regem o movimento da água e os impactos decorrentes do uso da terra em termos quali-quantitativos são essenciais para que o gerenciamento dos recursos hídricos seja realizado de maneira integrada. Entretanto, a aquisição de dados e informações hidrológicas em campo muitas vezes requer a implementação de infraestrutura adequada, equipamentos e mão de obra, demandando tempo e recursos financeiros. No caso de um país com dimensões continentais como o Brasil, onde a rede hidrográfica é densa e vasta, tais limitações relativas ao levantamento de dados e informações hidrológicas são ainda mais evidentes.

Diante deste contexto, os modelos hidrológicos se consagraram como importantes ferramentas de análise ambiental, visto que auxiliam não somente o entendimento dos processos ocorrentes nas bacias hidrográficas, mas também as inter-relações existentes entre os mesmos. Dessa maneira, foram desenvolvidas ferramentas para um amplo espectro de finalidades, escalas de aplicação e variados passos de tempo, abrangendo desde modelos simplificados voltados à simulação de processos específicos até modelos de base física altamente complexos que regem, além do fluxo da água, a influência das atividades antrópicas sobre os componentes da bacia.

Dentre a grande variedade de modelos existentes, o Soil and Water Assessment Tool (SWAT), desenvolvido pelo Departamento de Agricultura dos Estados Unidos (USDA) em parceria com a Universidade Texas A\&M, é considerado uma ferramenta bastante difundida e eficaz para avaliação dos recursos hídricos e predição de impactos de fontes não pontuais, sendo aplicado a uma ampla gama de escalas e condições ambientais em todo o mundo (ARNOLD et al., 2012a).

No Brasil as aplicações do SWAT tiveram início no final dos anos 90 e se consolidaram durante a década seguinte com a publicação de trabalhos em várias regiões do país. Grande parte destas aplicações visa avaliar a capacidade do modelo em representar adequadamente determinados componentes das bacias hidrográficas brasileiras, tendo como 
foco principal as simulações de vazão, sedimentos, e, com menor frequência, nutrientes e outros parâmetros de qualidade da água (GARBOSSA et al., 2011).

Desenvolvido em agências governamentais e universidades norte-americanas, o SWAT reúne em sua estrutura uma série de rotinas e algoritmos provenientes de observações e experimentos de campo conduzidos nos países do hemisfério norte, sendo, portanto, representativos das condições típicas daquelas localidades. Além disso, os parâmetros e configurações originais do modelo relacionados aos solos, clima, usos da terra, crescimento vegetal, operações de manejo, dentre outros, foram compilados a partir de estudos realizados nos Estados Unidos e Europa, retratando valores tipicamente observados em regiões temperadas.

Conforme aponta Caiado (2005), as bacias hidrográficas situadas na zona tropical e na região equatorial diferem das localizadas nas regiões temperadas em uma série de aspectos, incluindo a predominância de maiores temperaturas, uma menor variação do fotoperíodo ao longo do ano, ocorrência de chuvas de maior intensidade, diferenças nas técnicas de manejo do solo e ciclos de cultivo, diferenças na mineralogia e na microbiota do solo, dentre outros. Portanto, a aplicação do SWAT em bacias com condições distintas das quais o modelo foi originalmente criado deve ser precedida de uma análise crítica avaliando as representações envolvidas no processo de modelagem.

Ainda que um grande número de trabalhos realizados no Brasil apresente simulações com calibrações consideradas boas ou satisfatórias para a vazão e/ou sedimentos, tais resultados não garantem necessariamente que os demais processos internos ocorrentes na bacia hidrográfica estejam sendo simulados corretamente (STRAUCH; VOLK, 2013). Conforme aponta Van Griensven et al. (2012), a avaliação do desempenho de um modelo hidrológico deve ir além da análise do ajuste entre dados observados e simulados, sendo fundamental verificar se os processos hidrológicos envolvidos (isto é, o escoamento superficial, infiltração, evapotranspiração, recarga subterrânea, dentre outros) estão sendo adequadamente representados pelo modelo. Desse modo, tais processos, assim como os valores dos parâmetros relacionados a eles, devem ser compatíveis com observações e medições realizadas em campo.

Nesse sentido, vários trabalhos realizados no Brasil utilizando o SWAT relatam a simulação de valores de evapotranspiração considerados inferiores ao que seria usualmente esperado em regiões tropicais, o que sugere uma possível limitação dos algoritmos utilizados no modelo em quantificar adequadamente tal componente do ciclo hidrológico (SOUSA, 2010; BONUMÁ, 2011; BONUMÁ et al., 2013; CASTRO, 2013; MELO NETO, 2013; 
SILVA, 2013; SANTOS, 2014). Além disso, constatações semelhantes são também reportadas em simulações realizadas em bacias localizadas no Quênia (VAN LOON; DROOGERS, 2007), no sul da Índia (WAGNER et al., 2011) e em Mali e na Costa do Marfim (BEGOU et al., 2016), todas localizadas na zona tropical da Terra.

Alguns trabalhos internacionais salientam ainda que as rotinas de simulação do crescimento vegetal utilizadas pelo SWAT foram desenvolvidas para regiões temperadas, abrangendo processos como a indução de dormência a cada ciclo vegetativo, não sendo, portanto, adequadas para aplicação em climas tropicais ou de monção (WAGNER et al., 2011; STRAUCH; VOLK, 2013, VAN GRIENSVEN; MAHARJAN; ALEMAYEHU, 2014). Tal fato é de extrema relevância e deve ser ponderado quando da aplicação do SWAT em bacias tropicais, visto que processos como a evapotranspiração, escoamento superficial e infiltração são fortemente influenciados pela vegetação.

Baseando-se neste contexto, o presente trabalho parte da premissa de que alguns algoritmos do modelo SWAT não são apropriados para representar determinados processos dos sistemas tropicais. Tal premissa pode ser ainda estendida aos valores dos parâmetros utilizados na alimentação destes algoritmos, indicando um campo em potencial para implementação de melhorias no processo de modelagem. Nesse sentido, este estudo dedicouse a investigar a adequabilidade dos métodos relacionados à determinação da evapotranspiração pelo modelo SWAT de modo a propor modificações que resultem em uma representação hidrológica coerente com os valores usualmente observados nas bacias de regiões tropicais.

O estudo foi realizado partindo-se da análise dos resultados simulados pelo modelo com suas configurações originais, onde identificaram-se lacunas e deficiências no processo de simulação e foram propostas alterações tanto em rotinas de simulação quanto em parâmetros específicos. Após as mudanças uma nova simulação foi realizada para averiguar as respostas do modelo, utilizando-se uma abordagem comparativa para avaliação dos resultados das simulações. Ademais, procurou-se realizar os procedimentos aqui propostos para cinco bacias hidrográficas do estado de São Paulo, de modo a avaliar sua aplicabilidade em áreas com diferentes escalas e características fisiográficas distintas, bem como sinalizar a possibilidade de aplicação dos procedimentos em outras localidades. 


\section{OBJETIVOS}

O objetivo principal deste trabalho consiste em realizar o aprimoramento da modelagem hidrológica do modelo SWAT através de modificações nos métodos de determinação da evapotranspiração e demais processos relacionados.

Os objetivos específicos deste trabalho consistem em:

- Revisar as rotinas de simulação e parâmetros envolvendo o cálculo da evapotranspiração e demais processos relacionados, identificando possíveis elementos não apropriados à simulação em bacias brasileiras;

- Realizar as devidas alterações em rotinas de simulação e parâmetros de forma a obter uma melhor representação dos processos;

- Avaliar as respostas do modelo em relação às modificações propostas em diferentes níveis, desde as menores unidades de simulação até a bacia hidrográfica em sua totalidade;

- Avaliar o desempenho do modelo na estimativa da vazão através da comparação entre a simulação com as configurações originais e a simulação com as modificações propostas. 


\section{REVISÃO BIBLIOGRÁFICA}

\subsection{Balanço hídrico em bacias hidrográficas}

A água pode ser encontrada em praticamente todo o planeta, seja na atmosfera, na superfície dos continentes, mares e oceanos, no subsolo e nos seres vivos, ocorrendo em permanente circulação sob a forma de diferentes estados físicos. O conjunto de processos que envolvem o movimento ou transferência das massas de água, tanto de um ponto do planeta a outro, como entre seus diferentes estados, é denominado ciclo hidrológico.

Segundo Silveira (2009), o ciclo hidrológico é impulsionado fundamentalmente pela energia solar associada à gravidade e à rotação terrestre. O movimento da água tem sua origem na chegada contínua da energia solar, que faz com que as águas superficiais evaporem, sejam transportadas pelo vento por grandes distâncias e, sob condições apropriadas, condensem e precipitem. Ao atingir o solo, a água precipitada move-se pela ação da gravidade para os pontos mais baixos do terreno até chegar aos rios e oceanos. Parte da água que precipitou sobre solos permeáveis infiltra-se e atinge os lençóis subterrâneos, enquanto outra parte é absorvida pelos vegetais, sendo eliminada posteriormente sob a forma de vapor d'água (PORTO; BRANCO; LUCA, 1991).

O ciclo hidrológico, se considerado de maneira global, pode ser visto como um sistema fechado, uma vez que a quantidade total da água existente em nosso planeta se mantém constante. Segundo Silveira (2009), à medida que se consideram áreas menores de drenagem, o ciclo hidrológico passa a ser melhor caracterizado como um ciclo aberto ao nível local. Nesse sentido, as bacias hidrográficas traduzem-se como uma escala espacial de uso bastante consagrado na hidrologia, pois compreendem sistemas naturais abertos bem definidos que estão em constante troca de energia e matéria com o meio externo (LIMA, 1996).

De acordo com Righetto (1998), qualquer sistema hidrológico pode ser analisado a partir da quantificação das entradas (vazões ou volumes afluentes) e saídas de água (vazões ou volumes efluentes), através de processos físicos determinísticos ou probabilísticos expressos matematicamente por uma ou mais funções de transferência. Dessa maneira, através da aplicação do princípio da conservação das massas em uma bacia hidrográfica ou em um sistema hídrico particular, torna-se possível traduzir quantitativamente o conceito de ciclo 
hidrológico sob a forma de uma relação matemática denominada equação hidrológica ou equação do balanço hídrico.

Para a elaboração do balanço hídrico é fundamental que se defina o espaço físico onde este será realizado, bem como o intervalo de tempo e quais os processos a serem considerados. Segundo Freire e Omena (2013), em estudos de disponibilidade hídrica, o balanço deve ser elaborado para longos intervalos de tempo, considerando-se os processos sob a forma de totais mensais. Processos que se desenvolvem a intervalos curtos, a exemplo da infiltração, não têm interesse direto ao balanço, sendo considerados apenas processos como a precipitação, a evapotranspiração, o escoamento superficial e os armazenamentos superficial e subterrâneo, analisados sob a forma de totais. Já em estudos hidrológicos visando à estimativa de vazões de cheia ou descargas de projeto são considerados os processos de precipitação, infiltração e o escoamento superficial, sendo estes analisados sob a forma de taxas de ocorrência a curtos intervalos de tempo (minutos, horas ou dias).

Nas aplicações da equação do balanço hídrico em que o volume de controle é a bacia hidrográfica, o volume da água precipitada corresponde à quantidade de entrada, enquanto a quantidade de saída é geralmente dada pela soma do volume de água escoado pela seção exutória com os volumes correspondentes às perdas intermediárias, decorrentes da evaporação e transpiração. Ainda, dependendo da aplicação que se faz, as quantidades infiltradas profundamente podem ser tratadas como perdas (saídas) ou incorporadas no termo de armazenamento. Um exemplo de tal representação pode ser observado na Figura 1, na qual os processos hidrológicos de uma bacia hidrográfica são retratados através de uma seção transversal do canal.

No sistema apresentado, uma parcela da precipitação é interceptada pela vegetação e evaporada, enquanto outra parcela atinge o solo. Dependendo da capacidade de infiltração, parte da água que chega ao solo sofre infiltração e percola no perfil, ao passo que outra parte escoa superficialmente. A água infiltrada percola através da zona insaturada e recarrega o reservatório subterrâneo superficial, enquanto outra parte escoa lateralmente no perfil e contribui para o fluxo do rio na forma de escoamento subsuperficial. A água armazenada no solo pode ainda ser ainda absorvida pelas plantas e eliminada para a atmosfera na forma de transpiração estomatal ou sofrer ascensão capilar em direção à superfície e ser evaporada. Por fim, parte da água que adentra o aquífero superficial alimenta o canal através do fluxo de base, enquanto outra parte percola para camadas mais profundas. 


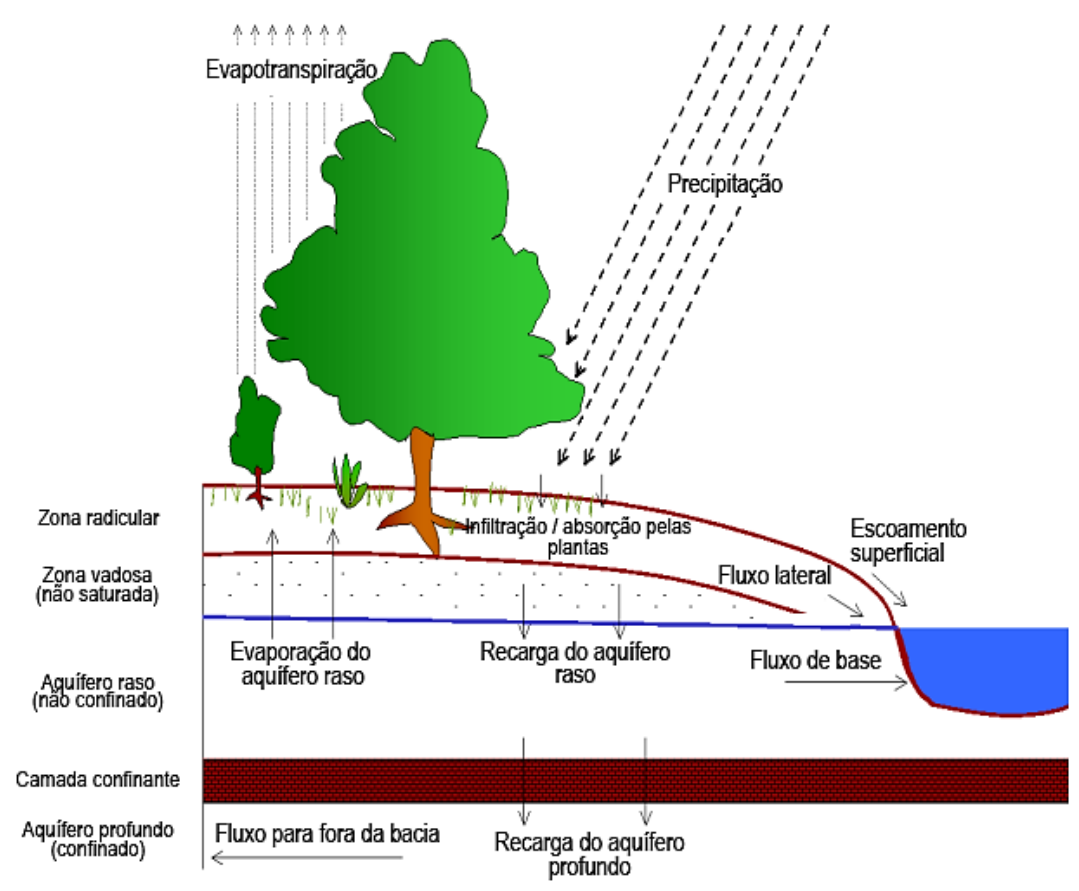

Figura 1 - Representação esquemática dos processos hidrológicos de uma bacia hidrográfica (adaptado de NEITSCH et al., 2011).

De forma simplificada, para um dado período de tempo (dias, meses ou ano), a equação do balanço hídrico para um volume de controle que inclui a superfície e o perfil de solo será dada conforme a equação 3.1, onde seus termos são expressos em mm por unidade de tempo.

$$
R=\Delta S W+Q_{\text {surf }}+E_{a}+w_{\text {seep }}+Q_{g w}
$$

Onde $R$ é a precipitação $(\mathrm{mm}), \Delta S W$ é a variação do armazenamento da água do solo $(\mathrm{mm}), Q_{\text {surf }}$ é o escoamento superficial $(\mathrm{mm}), E_{a}$ é a evapotranspiração $(\mathrm{mm})$, $w_{\text {seep }}$ é a quantidade de água que percola na zona vadosa $(\mathrm{mm})$ e $Q_{g w}$ é a quantidade de água que retorna ao curso d'água por escoamento subsuperficial (mm).

Considerando-se uma bacia hidrográfica ideal, isto é, onde todos os fluxos positivos e negativos possam estar sob controle experimental e não ocorram vazamentos e nem perdas por percolação profunda, a equação acima pode ser simplificada de acordo com:

$$
R-E_{a}-Q \pm \Delta S W=0
$$


Em que, após o ajuste das unidades, $R$ é a precipitação $\left(\mathrm{m}^{3} . \mathrm{s}^{-1}\right), E_{a}$ é a evapotranspiração $\left(\mathrm{m}^{3} \cdot \mathrm{s}^{-1}\right), Q$ é a vazão do canal $\left(\mathrm{m}^{3} \cdot \mathrm{s}^{-1}\right)$ e $\Delta S W$ é a variação do armazenamento da água na bacia $\left(\mathrm{m}^{3} \cdot \mathrm{s}^{-1}\right)$.

Teoricamente, a aplicação do balanço hídrico é possível para qualquer tipo de região, embora esteja condicionada à quantificação dos termos individuais da equação, o que delimita sua aplicabilidade em um senso prático (EMÍDIO, 2008). A determinação destes termos envolve o levantamento de dados observados ou de expressões que representem os processos físicos adequadamente, os quais nem sempre se encontram disponíveis, além do fato de algumas variáveis serem de quantificação bastante complexa e dependerem de métodos analíticos pouco precisos.

Nas seções seguintes será realizada uma rápida abordagem sobre os componentes utilizados com maior frequência em estudos de aplicação do balanço hídrico em bacias, sendo apresentados os principais métodos de obtenção destas variáveis.

\section{Precipitação}

A precipitação é entendida como toda água proveniente do meio atmosférico que atinge a superfície terrestre, seja na forma de chuva, neblina, granizo, orvalho, geada ou neve. As principais grandezas utilizadas para caracterização das precipitações são a altura pluviométrica, ou seja, a lâmina d'água que se formaria sobre o solo como resultado de uma certa chuva, o tempo de duração do evento e a intensidade (BERTONI; TUCCI, 2009; COLLISCHONN; TASSI, 2008).

Devido à sua aleatoriedade no tempo e em magnitude, a precipitação é o elemento mais sensível para garantir a qualidade e confiabilidade de um balanço hídrico nas aplicações práticas. Sua medida deve ser representativa e correta, de modo que registre efetivamente a distribuição da quantidade de chuva em uma determinada área com o mínimo de erro (TROVATI, 2007).

A determinação da precipitação pode ser realizada tanto por métodos diretos como indiretos. Para as condições climáticas do Brasil, onde a absoluta maioria da precipitação cai sob a forma de chuva, a medição direta é realizada pontualmente por meio de pluviômetros e pluviógrafos (SANTOS et al., 2001). Dentre os métodos indiretos, pode-se citar a utilização de radares meteorológicos, os quais emitem pulsos de radiação eletromagnética que são refletidos pelas partículas de chuva na atmosfera, sendo este sinal correlacionado à intensidade de chuva que está caindo em uma região. Também é possível obter estimativas da 
precipitação a partir de imagens obtidas por sensores instalados em satélites, onde a temperatura do topo das nuvens é correlacionada com a precipitação (COLLISCHONN; TASSI, 2008). Segundo Santos et al. (2001), a principal vantagem destes métodos é a geração de medidas em um contínuo espacial, porém apresentam erros relativamente grandes, sendo pouco úteis em estudos que requerem quantificações exatas.

Conforme apontado por Keller Filho et al. (2006), a chuva é uma variável meteorológica de grande variação espacial e temporal, sendo influenciada diretamente por fatores como latitude, altitude, continentalidade, disposição e orientação do relevo, dentre outros. No estado de São Paulo, por exemplo, onde há predominância de climas tropicais e subtropicais, a pluviosidade anual varia entre 1200 e $2500 \mathrm{~mm}$, com os maiores totais ocorrendo ao longo da Serra do Mar e decrescendo em direção ao interior do estado (SANT'ANNA NETO, 2005). Já em áreas de clima equatorial, como na região da bacia amazônica, a precipitação média anual pode ultrapassar $3000 \mathrm{~mm}$ de chuva, chegando a até 3500 mm (CORREIA et al., 2007).

\section{Evapotranspiração}

O termo evapotranspiração é utilizado para designar o processo total de conversão de água do sistema solo-planta para a forma de vapor, bem como sua transferência para a atmosfera. Tal transferência ocorre fisicamente nas formas de difusão molecular e turbulenta, sendo controlada por fatores como a disponibilidade de energia, pela demanda atmosférica e pela disponibilidade de água no solo.

Existem conceitos distintos de evapotranspiração utilizados na literatura, os quais refletem as diferentes condições experimentais em que são realizados estes estudos. Thornthwaite (1948) introduziu o conceito de evaporação potencial (ETp) como sendo a perda máxima de água em determinada unidade de tempo de uma superfície de dimensões suficientemente grandes, de modo a minimizar os efeitos de energia advectiva local, completamente coberta de vegetação em fase de crescimento ativo e sob condições ótimas de umidade do solo. Tal definição de ETp é semelhante a de Penman (1948), o qual acrescenta que a vegetação deveria ser rasteira e com altura uniforme. Sob estas condições de contorno, e considerando-as invariáveis no tempo e espaço, a evapotranspiração ocorre como função apenas do balanço vertical de energia, ou seja, das condições atmosféricas sobre a vegetação, sem interferências advectivas (CARVALHO et al., 2011). Fora de tais condições, ou seja, em situação de restrição hídrica do solo e demais configurações de cobertura vegetal, tem-se a 
evapotranspiração real (ETr), a qual é sempre igual ou inferior à ETp (CAMARGO; CAMARGO, 2000).

$\mathrm{Na}$ maioria dos estudos relacionados à evapotranspiração geralmente adota-se a grama como cultura padrão, e, em determinados tipos de clima, a alfafa (CARVALHO et al., 2011). Devido às diferenças entre as culturas utilizadas, mesmo se tratando de variedades de grama, verificou-se com o passar do tempo a necessidade de padronização e atualização do procedimento de cálculo da evapotranspiração potencial. Nesse sentido, a Organização das Nações Unidas para Agricultura e Alimentação (FAO) estabeleceu o conceito de evapotranspiração de referência (ETo), sendo definido como a evapotranspiração de uma extensa superfície com vegetação rasteira (gramado) em crescimento ativo, cobrindo totalmente o solo, sem restrição hídrica e com ampla área de bordadura para evitar a advecção de calor sensível de áreas adjacentes. A cultura de referência utilizada é uma cultura hipotética com valores fixos de albedo de 0,23 , altura de $0,12 \mathrm{~m}$ e resistência do dossel de 70 s.m ${ }^{-1}$ (ALLEN; SMITH; PERRIER, 1994).

Apesar da proposição da FAO, ainda é bastante comum o uso dos termos ETp e ETo como sinônimos. Segundo Carvalho et al. (2011), o termo ETp é mais utilizado em estudos climatológicos, estando relacionado à análise do potencial hídrico de uma região, enquanto o termo ETo é bastante empregado em estudos de planejamento agrícola.

A evapotranspiração pode ser mensurada a partir de medidas diretas ou estimada por meio de métodos teóricos e empíricos. A determinação direta é realizada a partir de lisímetros, definidos por Aboukhaled, Alfaro e Smith (1982) como equipamentos constituídos de uma caixa impermeável localizada no campo, sendo a mesma preenchida com solo e vegetação característicos dos quais se deseja medir a evapotranspiração, mantendo a mesma sequência de horizontes do solo original. O isolamento deste volume de solo vegetado permite que todas as entradas e saídas de água deste sistema sejam controladas (SENTELHAS, 1998). Quando adequadamente preenchidos, os lisímetros apresentam valores de evapotranspiração representativos da área circundante (PRUITT; ANGUS, 1960; HOWELL; SCHNEIDER; JENSEN, 1991).

Segundo Medeiros (2002), os lisímetros podem ser classificados em dois tipos principais conforme seu funcionamento: os de pesagem e os de não pesagem. Os lisímetros de pesagem envolvem vários princípios e dispositivos de medição, como pesagem mecânica com balanças, pesagem eletrônica com células indicadoras de esforço ou, ainda, sistemas de pesagem hidráulica. Estes aparelhos permitem conhecer, dia a dia, a variação no peso do solo que, desprezando-se o acréscimo diário de peso das plantas, será o valor da evapotranspiração 
(SENTELHAS, 1998). Os demais tipos de lisímetro têm como princípio a medição volumétrica, permitindo obter a evapotranspiração de uma cultura nele implantada através do balanço dos volumes d'água.

Segundo Lima (2010), a medição direta da evapotranspiração real em grandes áreas consome muito tempo e recursos. Por isso, adota-se como prática geral simular a ETr com base na estimativa da ETo, a qual pode ser obtida a partir de modelos baseados em leis físicas e relações empíricas, geralmente necessitando de dados climático-fisiológicos para a sua aplicação (CRUZ, 2005). Dentre os métodos mais utilizados, quer pela simplicidade ou pelo grau de confiabilidade, destacam-se os de Penman-Monteith-FAO (ALLEN; SMITH; PERRIER, 1994), Thornthwaite (THORNTHWAITE, 1948), Priestley-Taylor (PRIESTLEY; TAYLOR, 1972) e Penman Modificado (DOORENBOS; PRUITT, 1977). Muitos destes métodos possuem variantes devido a ajustes e calibrações locais, elevando ainda mais a quantidade de métodos disponíveis (CARVALHO et al., 2011).

\section{Escoamento superficial}

O escoamento superficial, também denominado escorrimento superficial, deflúvio superficial ou escoamento rápido, é a fase do ciclo hidrológico que resulta do excedente das águas precipitadas que não se infiltraram, as quais acabam escoando pelos declives em direção a depressões, lagos, cursos d'água e mares (PRUSKI; BRANDÃO; SILVA, 2003). Para muitos autores, o escoamento superficial abrange desde o excesso de precipitação que se desloca pela superfície após uma chuva de longa duração até o escoamento que ocorre no leito de um curso d'água (RIGHETTO, 1998; TUCCI, 2009). Entretanto, para fins de definição, neste trabalho será considerado como escoamento superficial apenas a parte terrestre do processo, sem considerar o escoamento nos canais fluviais.

Segundo Pruski, Brandão e Silva (2003), a geração do escoamento superficial tem início quando a capacidade de infiltração do solo é excedida, ocasionando o empoçamento da água nas depressões existentes na superfície do solo. A partir desse momento, a magnitude do escoamento passa a depender da intensidade da chuva, ocasionando escoamentos de superfície distribuídos espacialmente em pequenas áreas. Esses escoamentos representam contribuições laterais aos canais existentes na bacia, os quais transportam as águas pluviais para o sistema fluvial (RIGHETTO, 1998). De acordo com Tucci (2009), em pequenas bacias o escoamento ocorre predominantemente sobre a superfície do solo, em drenos com perdas hidráulicas maiores, mas com maior declividade. Já em bacias de grande porte, o processo 
predominante é o deslocamento da onda de cheia por um canal definido, de menor declividade, mas com perda de carga menor.

A medição direta do escoamento superficial em campo é realizada através da montagem de parcelas experimentais, bastante utilizadas em estudos de erosão do solo. Nestas parcelas são feitos tratamentos variados implantando-se diferentes tipos de cobertura e de culturas agrícolas. Após cada evento chuvoso, a água escoada é direcionada para um reservatório instalado na parte mais baixa das parcelas, sendo quantificada a partir de linígrafos instalados nos vertedouros de cada parcela (LELIS et al., 2012).

Como as medições de escoamento superficial em campo são trabalhosas e demandam tempo, são comuns as estimativas através de métodos empíricos. Dentre os mais utilizados, destaca-se o Método do Número da Curva, proposto pelo Serviço de Conservação de Solos do Departamento de Agricultura dos Estados Unidos (SCS-USDA). Tal método é bastante preciso e de fácil aplicação, permitindo determinar a quantidade aproximada de escoamento superficial direto gerado numa área específica em resposta a um evento de precipitação. $\mathrm{O}$ método tem como principal variável o número da curva de escoamento superficial, $C N$, o qual é pré-determinado com base nas informações de cobertura do solo, do tipo de solo e das condições de umidade antecedentes (USDA, 1986).

O cálculo do escoamento por este método é efetuado pela seguinte equação:

$$
Q_{\text {surf }}=\frac{\left(R_{\text {day }}-0,2 S\right)^{2}}{R_{\text {day }}+0,8 S}
$$

Em que $\mathrm{Q}_{\text {surf }}$ é o escoamento superficial produzido em determinada chuva (mm), $R_{\text {day }}$ é a precipitação acumulada $(\mathrm{mm})$ e $S$ é a capacidade máxima de infiltração $(\mathrm{mm})$. A capacidade máxima de infiltração, $S$, relaciona-se com o parâmetro $C N$ a partir da equação:

$$
S=\left(\frac{25400}{C N}\right)-254
$$

Onde $C N$ é o número da curva, um valor tabelado que define o complexo hidrológico solo-vegetação, e os demais valores numéricos são coeficientes para ajuste de unidades. Os valores de $C N$ resultaram da análise empírica de dados obtidos por observação do processo de geração de escoamento superficial em bacias hidrográficas e em parcelas experimentais monitoradas pelo SCS-USDA. Tal parâmetro compreende valores entre 30 e 100, onde 
números mais baixos indicam um menor potencial de geração de escoamento, enquanto números maiores são indicadores de maior potencial.

\section{Infiltração}

Infiltração é o processo de passagem de água da superfície para o interior do solo. Tal processo depende fundamentalmente da água disponível para infiltrar, da natureza do solo, do estado da sua superfície e das quantidades de água e ar inicialmente presentes no seu interior (TUCCI, 2009). À medida que a água infiltra, as camadas superiores do solo vão umedecendo de cima para baixo e vão atingindo a saturação, condição em que todos os poros estão ocupados por água. Este movimento de redistribuição da água dentro do perfil é comumente referido como percolação (LIMA, 2008).

Segundo Bernardo, Soares e Mantovani (2006), a capacidade de infiltração é uma propriedade do solo que representa a velocidade (ou taxa) máxima que o solo em dada condição pode absorver a água da chuva. A velocidade de infiltração é máxima no início do evento chuvoso e decresce rapidamente de acordo com as condições do solo, se aproximando gradualmente de um valor mínimo constante, sendo essa condição estável denominada velocidade de infiltração básica ou infiltrabilidade básica.

A medição da infiltração em campo pode ser realizada pelo emprego de diferentes métodos, sendo bastante comum a utilização de infiltrômetros ou anéis concêntricos. Tal aparelho consiste basicamente de dois cilindros concêntricos que devem ser cravados no solo e preenchidos com água, cujo nível deve ser medido em intervalos de tempo pré-determinados de modo a obter a infiltração vertical neste período (COELHO; MIRANDA; DUARTE, 2000). Outras técnicas utilizadas consistem no uso de simuladores de chuva em parcelas experimentais (ALVES SOBRINHO; FERREIRA; PRUSKI, 2002) e o método do perfil instantâneo (HILLEL; KRENTOS; STYLIANOU, 1972; BARROS et al., 2014).

Existe um grande número de modelos teóricos e empíricos criados com a finalidade de quantificar e descrever o processo de infiltração da água no solo. Os modelos de base física foram desenvolvidos a partir de fundamentos relacionados à lei da conservação da massa e à teoria do escoamento em meios porosos (Lei de Darcy), a exemplo dos modelos de Philip (1957) e Green e Ampt (1911). Segundo Cecílio et al. (2003), o modelo de Green e Ampt exprime a infiltração em função da condutividade hidráulica do solo saturado, do potencial matricial na frente de umedecimento e das umidades inicial e de saturação. É um dos modelos 
que apresentam maior potencial de utilização, devido à sua simplicidade e por estar fundamentado no processo físico da infiltração.

Já os modelos empíricos são baseados em dados derivados de experimentos de campo ou laboratório, a exemplo dos modelos de Horton (1940), Kostiakov (1932) e o Método do Número da Curva (USDA; SCS, 1972). Segundo Netto (2011), tais modelos têm as vantagens de permitir relacionar seus parâmetros às características do solo sem que estes obrigatoriamente tenham significado físico, além de englobar na determinação de suas constantes alguns fatores que são de difícil consideração nos modelos teóricos, como por exemplo a heterogeneidade do solo. A principal limitação dos modelos empíricos é o fato de os dados ajustados serem válidos apenas para as condições de solo próximas a aquelas em que foram determinados, não podendo ser extrapolados para condições significativamente diferentes (BRANDÃO; PRUSKI; SILVA, 2003).

\section{Escoamento subsuperficial ou fluxo lateral}

O escoamento subsuperficial, também denominado fluxo lateral ou escoamento hipodérmico, corresponde ao fluxo de água que escoa em subsuperfície, originado de água que percolou o solo e penetrou por uma descontinuidade com menor permeabilidade. Segundo Salemi (2009), tal escoamento ocorre quando há um decréscimo na condutividade hidráulica do solo em condição de saturação nas camadas de maior profundidade, ocasionando um acúmulo de água na subsuperfície que passa a fluir em direção à declividade do terreno. Tal fluxo desloca-se lateralmente em direção à rede de drenagem em velocidade semelhante ao escoamento superficial, porém sem conectar-se ao escoamento subterrâneo.

De acordo com Atkinson (1978), a forma mais comum de ocorrência do escoamento subsuperficial se manifesta através de um fluxo disperso laminar bem distribuído no terreno, porém tal forma de escoamento também pode ocorrer concentrada em estruturas denominadas pipes $^{1}$, apresentando fluxo hidráulico turbulento. O escoamento subsuperficial ainda pode, eventualmente, aflorar e incorporar-se ao escoamento superficial em seu percurso.

\footnotetext{
${ }^{1}$ Denominação dada aos macroporos ou dutos associados aos processos de erosão interna do solo. A origem desses grandes poros horizontais pode ser atribuída à ação da biota (túneis de raízes decompostas ou mesmo de animais fossoriais), à eluviação de material mineral para horizontes mais profundos do perfil de solo e aos processos de expansão e contração de argilominerais (OLIVEIRA, 1999).
} 
Segundo Castany (1967), a importância do escoamento de subsuperfície varia de acordo com as características dos solos, podendo atingir até $80 \%$ da vazão total escoada em encostas florestadas contendo espessa camada de húmus. A determinação de tal parcela em campo é bastante trabalhosa e pouco difundida, podendo-se citar técnicas como a construção de trincheiras para monitoramento do escoamento na vertente (SCHERRER et al., 2007) e o uso de traçadores geoquímicos (SCHLADOW; CLARK, 2008).

\section{Recarga subterrânea}

A recarga das águas subterrâneas é definida como o fluxo de água que alcança o aquífero, constituindo uma adição ao reservatório de água subterrânea. Tal fluxo chega à zona saturada principalmente a partir da percolação vertical proveniente da zona vadosa, mas também pode ter origem no escoamento lateral a partir das fronteiras do sistema (DE VRIES; SIMMERS, 2002). Segundo Barreto (2006), quando o fluxo provém diretamente da zona vadosa para o aquífero raso, a recarga é denominada como direta. Quando a água percolada segue linhas de fluxo que não surgem nos cursos d'água da bacia hidrográfica, atingindo, portanto, camadas mais profundas do aquífero, a recarga é denominada profunda.

Segundo Melo et al. (2005), a recarga pode acontecer de maneira natural, pela precipitação, pelos rios e canais e ainda por fenômenos artificiais introduzidos pelo homem, como técnicas de irrigação e urbanização. As taxas de recarga são limitadas, em grande parte, pela água disponível na superfície do terreno, sendo controladas por fatores climáticos, como a precipitação e evapotranspiração e pelas características geomorfológicas superficiais (topografia, solo e cobertura vegetal) (MAZIERO; WENDLAND, 2008).

A estimativa da recarga pode ser realizada a partir de medição direta por meio de lisímetros, tal como os utilizados em estudos de evapotranspiração. Quando estes são utilizados para estimar a recarga, determina-se o volume infiltrado a partir da zona de raízes, obtendo-se, portanto, a recarga potencial (KINZELBACH, 2002). Em relação aos métodos indiretos, destacam-se as técnicas baseadas no balanço hídrico, onde os processos hidrológicos são considerados como entradas e saídas de um balanço volumétrico. Durante o período de tempo analisado, a diferença entre o total de entradas e saídas deve ser igual à mudança da quantidade de água armazenada, permitindo-se estimar a recarga com base nos demais componentes (WAHNFRIED; HIRATA, 2005). A recarga também pode ser estimada utilizando-se traçadores, a partir das concentrações de substâncias na água, ou das proporções entre concentrações dessas substâncias (BARRETO, 2006). 


\section{Escoamento de base ou fluxo de base}

O escoamento de base ou fluxo de base é a parte do escoamento cuja origem provém do aquífero raso, também chamado de aquífero não confinado ou livre (SALEMI, 2009). Durante os eventos de chuva é grande a quantidade de água que atinge os aquíferos, especialmente o aquífero raso, ocasionando a elevação do nível da água subterrânea. Nos períodos secos, esta água armazenada no subsolo vai sendo lentamente descarregada para as nascentes dos rios e o nível da água subterrânea diminui (COLLISCHONN; TASSI, 2008).

De acordo com Fetter (1988), o volume do fluxo de base é diretamente proporcional ao gradiente hidráulico em direção ao rio e ocorre quando a superfície potenciométrica (ou nível do lençol freático) encontra-se acima do nível do canal, situação que caracteriza o rio como efluente (COSTA, 2005). No período sem chuvas, conforme há a depleção do nível freático, ocorre também uma diminuição da quantidade de água descarregada como fluxo de base. Tal declínio do fluxo basal de um corpo hídrico devido à ausência de precipitação é denominado recessão, e sua curva pode ser aproximada a uma equação exponencial decrescente (DOMENICO; SCHWARTZ, 1990).

A quantificação da contribuição do fluxo basal para a vazão total de um corpo d'água é geralmente realizada a partir de técnicas de separação de escoamento por meio do hidrograma. Em campo, podem ser aplicadas técnicas de maior complexidade utilizando isótopos ou análises químicas, de modo a identificar as diferentes origens da água que escoam num rio a cada momento (COLLISCHONN; TASSI, 2008).

\subsection{Modelos hidrológicos em escala de bacia hidrográfica}

A aplicação de modelos em estudos hidrológicos tem se mostrado como ferramenta essencial para a compreensão dos processos naturais que ocorrem na escala de bacia hidrográfica, haja vista a complexidade e as dificuldades envolvidas na quantificação direta de muitos destes componentes.

Diferentemente dos modelos com enfoque em processos individuais, ou mesmo dos modelos que simulam múltiplos processos, porém adotando escala de campo, os modelos concebidos em escala de bacia permitem simular os componentes hidrológicos através de uma abordagem holística, procurando compreender não somente os fenômenos na sua totalidade, mas também as inter-relações existentes entre eles (DANIEL et al., 2011). Em vista disso, tais 
modelos são cada vez mais utilizados na previsão de vazões e da qualidade da água, para prevenção de cheias e inundações, na operação de reservatórios, no manejo integrado de águas superficiais e subterrâneas, na avaliação da disponibilidade hídrica, em estudos de impactos do uso da terra e mudanças do clima, transporte de poluentes, dentre outras análises relacionadas ao gerenciamento dos recursos hídricos (SINGH; WOOLHISER, 2002; DHAMI; PANDEY, 2013).

Segundo Paiva (2003) os modelos podem ser classificados, quanto à sua estrutura, em empíricos e conceituais. Os modelos empíricos utilizam relações matemáticas baseadas em observações, sendo mais simples e pouco robustos, uma vez que são concebidos a partir de condições específicas. Desse modo, não permitem realizar simulações em condições para os quais o modelo não previu, tais como, chuvas extremamente altas e mudança de uso do solo (RENNÓ; SOARES, 2000). Já os modelos conceituais são baseados em processos físicos, procurando descrever as etapas que envolvem determinado fenômeno estudado. São modelos mais complexos, geralmente aplicados na escala de bacia hidrográfica ou de campo, requerendo uma maior quantidade de dados de entrada.

Os modelos podem também ser classificados em relação à escala temporal em que operam, sendo agrupados em contínuos ou discretos: os primeiros buscam representar longos períodos da série, muitas vezes contemplando épocas de comportamentos hidrológicos diferentes, enquanto os segundos objetivam modelar períodos e eventos isolados (BREDA, 2008). Além disso, os modelos ainda podem ser classificados em concentrados ou distribuídos. No primeiro caso, os parâmetros variam somente em função do tempo e são representados por equações com uma variável independente, sendo únicos para toda a área, enquanto no segundo podem variar também em relação ao espaço geográfico, utilizando-se para sua representação equações com mais de uma variável independente (MORO, 2005).

Os primeiros modelos hidrológicos surgiram há mais de um século, a partir do equacionamento de alguns processos hidrológicos simples, como, por exemplo, o Método Racional, proposto por Mulvany por volta de 1850 (MARINHO FILHO et al., 2012). Entretanto, apenas a partir de 1950, com o advento dos computadores, houve o desenvolvimento de modelos baseados em conceitos físicos, sendo uma alternativa para os modelos estocásticos utilizados até então (TUCCI, 2005). Nas décadas seguintes diversas agências governamentais de países desenvolvidos começaram a implementar programas de pesquisa hidrológica, resultando em modelos de abordagem espacial distribuída voltados a diversas finalidades. No final da década de 80, a partir de novas demandas dos hidrólogos com relação à representação digital do terreno, passou a ocorrer a integração entre modelos 
hidrológicos e Sistemas de Informação Geográfica (SIG), permitindo a criação de modelos de maior complexidade (SINGH; FIORENTINO, 1996).

A maior parte dos modelos descrevem apenas alguns dos processos que ocorrem numa bacia hidrográfica, haja vista a grande dificuldade de se representar tais processos por meio de equações. Entretanto, o avanço das técnicas computacionais permitiu o desenvolvimento de modelos de maior complexidade, capazes de simular não apenas um grande número de processos hidrológicos, mas também integrar outros componentes como o transporte de sedimentos, agroquímicos e simular aspectos qualitativos.

Conforme apontam Dhami e Pandey (2013), os modelos existentes apresentam uma ampla diversidade de características e singularidades, variando em relação às escalas de aplicação espacial e temporal, quanto aos processos modelados, em relação à base relacional dos processos e ao algoritmo utilizado na determinação destes. Na Tabela 1 são apresentadas as principais características de alguns dos modelos hidrológicos reportados com maior frequência pela literatura, sendo dada a seguir uma breve descrição sobre cada um deles.

O modelo TOPMODEL (Topography-Based Hydrological Model) incorpora um conjunto de conceitos hidrológicos para determinação da relação chuva-vazão desenvolvido por Beven e Kirkby (1979). Requer como dado de entrada na forma geoespacial apenas a altimetria na forma de Modelo Digital de Elevação (MDE), enquanto os demais parâmetros são constantes para toda a bacia. Segundo Franchini et al. (1996), dois componentes principais podem ser identificados em sua formulação: o primeiro representa o balanço hídrico no solo e o segundo a propagação do escoamento até o exutório da bacia. O modelo é baseado no conceito de área variável de contribuição, ou seja, o escoamento superficial é dependente da quantidade de área saturada na bacia, podendo esta variar a cada intervalo da simulação. Além disso, é constituído em sua estrutura por reservatórios interligados com diferentes tempos de armazenamento (SILVA; KOBIYAMA, 2007).

O modelo ANSWERS (Areal Nonpoint Source Watershed Enviroment Response Simulation) é composto de dois módulos principais, um destinado a processos hidrológicos e outro a processos erosivos. É aplicado a bacias pequenas e de médio porte com predominância de processos hidrológicos de superfície, podendo ser utilizado com SIG (BEASLEY; HUGGINS, 1980). No processo de modelagem a bacia é subdividida em várias células de tamanho regular e para cada unidade são obtidos valores homogêneos referentes ao relevo, precipitação, solo e cobertura do solo. Tem como foco principal a simulação do comportamento de bacias agrícolas durante e imediatamente após a precipitação, sendo útil no 
Tabela 1 - Comparativo entre as características de alguns modelos hidrológicos aplicáveis em escala de bacia, com a especificação do método de simulação dos principais processos hidrológicos (adaptado de DHAMI; PANDEY, 2013; DANIEL et al., 2011, BORAH; BERA, 2003).

\begin{tabular}{|c|c|c|c|c|c|c|c|c|c|}
\hline \multirow{2}{*}{ Modelo } & \multirow{2}{*}{$\begin{array}{l}\text { Principais componentes } \\
\text { simulados }\end{array}$} & \multirow{2}{*}{$\begin{array}{c}\text { Escala } \\
\text { temporal }\end{array}$} & \multirow{2}{*}{$\begin{array}{l}\text { Escala } \\
\text { espacial }\end{array}$} & \multirow{2}{*}{$\begin{array}{l}\text { Representação } \\
\text { da bacia }\end{array}$} & \multicolumn{5}{|c|}{ Representação dos processos hidrológicos } \\
\hline & & & & & Intercepção & Evapotranspiração & Esc. superficial & Infiltração & Esc. subterrâneo \\
\hline TOPMODEL & $\begin{array}{c}\text { Armazenamentos e } \\
\text { fluxos na zona não } \\
\text { saturada, saturada e } \\
\text { propagação do fluxo na } \\
\text { sub-bacia. } \\
\end{array}$ & $\begin{array}{c}\text { Único } \\
\text { evento } \\
\text { (simula de } \\
1 \text { a } 24 \\
\text { horas) } \\
\end{array}$ & $\begin{array}{c}\text { Semi- } \\
\text { distribuído }\end{array}$ & HRU & Não simulado & Não simulado & $\begin{array}{l}\text { Baseado no } \\
\text { índice } \\
\text { topográfico de } \\
\text { umidade }\end{array}$ & Não simulado & $\begin{array}{c}\text { Baseado no índice } \\
\text { topográfico de } \\
\text { umidade }\end{array}$ \\
\hline ANSWERS & $\begin{array}{l}\text { Intercepção, escoamento, } \\
\text { infiltração, drenagem } \\
\text { subsuperficial, erosão e } \\
\text { transporte de sedimentos }\end{array}$ & $\begin{array}{l}\text { Único } \\
\text { evento }\end{array}$ & Distribuído & Grade/células & $\begin{array}{c}\text { Volume de } \\
\text { intercepção } \\
\text { potencial } \\
\text { (BEASLEY; } \\
\text { HUGGINS, 1980) } \\
\end{array}$ & Não simulado & $\begin{array}{l}\text { Equações de } \\
\text { Manning e da } \\
\text { continuidade }\end{array}$ & $\begin{array}{l}\text { Relação Holton } \\
\text { (1961) e Overton } \\
\text { (1965) modificada }\end{array}$ & Equação de Darcy \\
\hline AGNPS & $\begin{array}{l}\text { Escoamento, infiltração, } \\
\text { erosão e transporte de } \\
\text { sedimentos }\end{array}$ & $\begin{array}{l}\text { Único } \\
\text { evento }\end{array}$ & Distribuído & Grade/células & Não simulado & Não simulado & $\begin{array}{l}\text { Método da Curva } \\
\text { Número (1972) }\end{array}$ & $\begin{array}{l}\text { Método da Curva } \\
\text { Número (1972) }\end{array}$ & Não simulado \\
\hline AnnAGNPS & $\begin{array}{l}\text { Hidrologia, transporte de } \\
\text { sedimentos, nutrientes e } \\
\text { pesticidas }\end{array}$ & $\begin{array}{l}\text { Contínuo } \\
\text { (passo } \\
\text { diário) }\end{array}$ & Distribuído & Grade/células & $\begin{array}{l}\text { Armazenamento } \\
\text { no dossel (VAN } \\
\text { DIJK et al., 2001) }\end{array}$ & $\begin{array}{l}\text { Método de Penman } \\
\text { Modificado } \\
\text { (PENMAN, 1948) }\end{array}$ & $\begin{array}{l}\text { Método da Curva } \\
\text { Número (1972) }\end{array}$ & $\begin{array}{l}\text { Método da Curva } \\
\text { Número (1972) }\end{array}$ & Equação de Darcy \\
\hline MGB-IPH & $\begin{array}{l}\text { Balanço de água no solo, } \\
\text { evapotranspiração, } \\
\text { escoamentos: superficial, } \\
\text { sub-superficial e } \\
\text { subterrâneo, escoamento } \\
\text { na rede de drenagem. }\end{array}$ & & Distribuído & HRU & $\begin{array}{l}\text { Dependente } \\
\text { da cobertura do } \\
\text { solo, expressa } \\
\text { em função do } \\
\text { IAF }\end{array}$ & $\begin{array}{l}\text { Método de Penman- } \\
\text { Monteith } \\
\text { (MONTEITH, 1965) }\end{array}$ & $\begin{array}{l}\text { Relação entre o } \\
\text { estado de } \\
\text { armazenamento e } \\
\text { a porcentagem de } \\
\text { área saturada } \\
\text { (TODINI, 1996) }\end{array}$ & Não especificado & Não especificado \\
\hline MIKE SHE & $\begin{array}{l}\text { Hidrologia, derretimento } \\
\text { da neve; interação entre } \\
\text { rios e aquíferos, } \\
\text { dispersão de solutos, } \\
\text { processos geoquímicos, } \\
\text { crescimento das plantas, } \\
\text { erosão e irrigação }\end{array}$ & $\begin{array}{l}\text { Contínuo } \\
\text { ou único } \\
\text { evento } \\
\text { (passo de } \\
\text { tempo } \\
\text { variável) }\end{array}$ & Distribuído & Grade/células & $\begin{array}{c}\text { Método } \\
\text { modificado de } \\
\text { Rutter } \\
\text { (KRISTENSEN; } \\
\text { JENSEN, 1975) }\end{array}$ & $\begin{array}{c}\text { Método de } \\
\text { Kristensen e Jensen } \\
\text { (KRISTENSEN; } \\
\text { JENSEN, 1975) e } \\
\text { Método do Balanço } \\
\text { Hídrico em Duas } \\
\text { Camadas } \\
\end{array}$ & $\begin{array}{c}\text { Método de } \\
\text { diferenças finitas } \\
\text { com onda } \\
\text { difusiva em 2D }\end{array}$ & $\begin{array}{l}\text { Equação de } \\
\text { Richards } \\
\text { (RICHARDS, 1931) }\end{array}$ & $\begin{array}{c}\text { Equação } \\
\text { diferencial parcial } \\
\text { do fluxo de águas } \\
\text { subterrâneas em } \\
\text { 3D }\end{array}$ \\
\hline SWAT & $\begin{array}{l}\text { Hidrologia, sedimentos, } \\
\text { propriedades do solo, } \\
\text { crescimento de culturas, } \\
\text { nutrientes, pesticidas, } \\
\text { manejo agrícola, } \\
\text { transporte nos canais }\end{array}$ & $\begin{array}{l}\text { Contínuo } \\
\text { (passo } \\
\text { diário) }\end{array}$ & $\begin{array}{c}\text { Semi- } \\
\text { distribuído }\end{array}$ & HRU & $\begin{array}{l}\text { Armazenamento } \\
\text { no dossel em } \\
\text { função do IAF }\end{array}$ & $\begin{array}{c}\text { Métodos de } \\
\text { Hargreaves (1985), } \\
\text { Priestley-Taylor } \\
\text { (1972) e Penman- } \\
\text { Monteith (1965). }\end{array}$ & $\begin{array}{l}\text { Métodos da } \\
\text { Curva Número } \\
\text { (1972) e Green \& } \\
\text { Ampt (1911) }\end{array}$ & $\begin{array}{c}\text { Método de } \\
\text { infiltração de } \\
\text { Green \& Ampt } \\
\text { (1911) }\end{array}$ & $\begin{array}{l}\text { Modelo de } \\
\text { armazenamento } \\
\text { cinemático } \\
\text { (SLOAN } \text { et al.,1983) }\end{array}$ \\
\hline
\end{tabular}


planejamento e na avaliação de estratégias para controlar a poluição de áreas intensamente cultivadas (ROO et al., 1989; DANIEL et al., 2011).

O modelo AnnAGNPS (Annualized Agricultural Non-Point Source) foi desenvolvido com o objetivo de avaliar as respostas das bacias hidrográficas em relação às praticas de manejo conservacionistas (BINGNER; THEURER, 2005). É um modelo de simulação contínua e passo de tempo diário capaz de representar elementos hidrológicos, sedimentos e cargas poluidoras em bacias com elevada atividade agrícola. Os parâmetros de entrada são considerados de forma distribuída, com a subdivisão da bacia em pequenas células com características homogêneas de manejo, tipo de solo e cobertura, sendo tal divisão condicionada aos limites hidrológicos definidos através da interface SIG. A partir destas células individuais, são determinados os escoamentos, sedimentos e produtos químicos associados ao movimento da água pela bacia, a qual pode provir de eventos de precipitação, irrigação ou na forma de neve derretida (YUAN et al., 2010). O AnnAGNPS foi concebido a partir do modelo de evento único AGNPS (YOUNG et al, 1989), a partir do qual foram incluídas melhorias significativas em sua modulação original.

Desenvolvido no Brasil, o modelo MGB-IPH (Modelo de Grandes Bacias) tem como foco a simulação do processo de transformação da chuva em vazão em grandes bacias hidrográficas (com áreas superiores a $10000 \mathrm{~km}^{2}$ ). Trata-se de um modelo distribuído no qual há divisão da área em minibacias e discretização em HRUs, requerendo como dados de entrada espaciais o mapa de solos, uso da terra e o MDE, além de dados climáticos e fluviométricos (FAN; COLLISCHONN, 2014). O modelo é composto de módulos para o cálculo do balanço de água no solo, evapotranspiração, escoamentos superficial, subsuperficial e subterrâneo e escoamento na rede de drenagem (TUCCI; COLLISCHONN, 2001). O principal resultado gerado pelo MGB-IPH é a vazão nas minibacias que compõem a área simulada, além de informações como o balanço de água no solo, evapotranspiração diária e precipitação diária.

O Mike SHE (Systeme Hydrologique European) é um modelo de base física, determinístico e distribuído que requer um grande número de parâmetros de entrada. $\mathrm{O}$ modelo compreende um grande número de processos do ciclo hidrológico em sua estrutura, como a evapotranspiração, interceptação, deflúvio, fluxo nas zonas insaturada e saturada, dentre outros. Pode simular o movimento das águas superficiais e subterrâneas e suas interações, além do transporte de sedimentos, nutrientes, pesticidas, e poluentes hídricos, sendo aplicável em diferentes escalas (GAYATHRI; GANASRI; DWARAKISH, 2015). As características da bacia são representadas através da discretização horizontal e vertical dentro 
de uma rede ortogonal de grades. Desta maneira, a variabilidade espacial dos parâmetros como elevação, tipo de solo (parâmetros hidráulicos do solo), cobertura do solo, precipitação e evapotranspiração potencial podem ser adequadamente representados (LUCAS, 2009).

Com relação ao modelo SWAT (Soil and Water Assessment Tool), por ser a ferramenta utilizada neste trabalho, será apresentado um maior detalhamento de suas características na próxima seção.

\subsection{O modelo SWAT: principais características e panorama geral das aplicações}

O modelo SWAT, acrônimo de Soil and Water Assessment Tool, foi desenvolvido pelo Departamento de Agricultura dos Estados Unidos (USDA) em parceria com a Universidade Texas A\&M (NEITSCH et al., 2011). A primeira versão do SWAT foi implementada no início da década de 90, surgindo como um aprimoramento do modelo SWRRB (Simulator for Water Resources in Rural Basins), desenvolvido por Williams, Nicks e Arnold (1985). Outros modelos que contribuíram significativamente para o seu desenvolvimento foram o CREAMS (Chemicals, Runoff, and Erosion from Agricultural Management Systems) (KNISEL, 1980), o GLEAMS (Groundwater Loading Effects of Agricultural Management Systems) (LEONARD; KNISEL; STILL, 1987) e o EPIC (Erosion Productivity Impact Calculator) (WILLIAMS; JONES; DYKE, 1984).

O SWAT é um modelo matemático de parâmetros semi-distribuídos desenvolvido com a finalidade de predizer o impacto de práticas de manejo do solo em relação à água, sedimento e produção química agrícola em bacias hidrográficas complexas não instrumentadas sobre longos períodos de tempo (NEITSCH et al., 2011). É considerado um modelo de base física, ou seja, ao invés de incorporar equações de regressão para descrever a relação entre as variáveis de entrada e saída, os processos associados ao ciclo hidrológico, ao movimento de sedimentos, crescimento das plantas, ciclo de nutrientes, dentre outros, são modelados utilizando os dados de entrada disponíveis.

Outra característica importante do modelo é a sua continuidade temporal, a qual permite a simulação dos processos físicos sequencialmente num intervalo de tempo delimitado pelo usuário, de modo a fornecer séries temporais como dado de saída (TIM, 1996). Tal característica permite que possam ser simulados impactos de longo prazo nos componentes do meio natural, como o aumento gradual dos poluentes nos solos e o impacto nos corpos d’água (NEITSCH et al., 2011). Por outro lado, os mesmos autores ressaltam que 
o SWAT não é um modelo concebido para simular detalhadamente eventos únicos, como cálculos de propagação de cheias, por exemplo.

Em sua concepção, o modelo SWAT foi implementado como uma ferramenta de linha de comando na qual as entradas e saídas eram arquivos do tipo texto. Com o aprimoramento das técnicas de geoprocessamento e a popularização dos Sistemas de Informação Geográfica (SIG), foram desenvolvidas ferramentas que permitiram a integração do SWAT com as operações espaciais disponíveis nestes softwares. Dentre tais ferramentas, destaca-se pela sua utilização em larga escala a extensão ArcSWAT, a qual possibilita a inserção de dados de entrada do modelo através da interface gráfica do software ArcGIS, desenvolvido pela ESRI (Environmental Systems Research Institute). Segundo Tucci (2005), este tipo de integração, além de facilitar a manipulação pelo usuário, ainda auxilia na aquisição de dados físicos, principalmente em modelos semi-distribuídos, em que é grande a quantidade de dados espaciais envolvidos.

A associação do modelo com a tecnologia SIG fornece ainda uma plataforma integrada para gerenciar, analisar e apresentar diferentes tipos de dados, podendo facilitar a compilação de informações e a visualização dos parâmetros envolvidos. Além disso, também possibilita a calibração do modelo de uma forma intuitiva e auxilia no pós-processamento dos resultados através de sua tabulação e mapeamento, sintetizando as informações para a tomada de decisão (TSOU; WHITTEMOREZ, 2001).

Segundo Bian et al. (1996), dada a complexidade do modelo SWAT e do ArcGIS, a integração entre estas ferramentas é realizada através de uma arquitetura multi-componente onde ambos são tratados como dois componentes mestre independentes. O projeto conceitual do sistema de integração inclui uma interface gráfica de usuário e, internamente, uma base de dados compartilhada para acoplar os dois sistemas. A interface gráfica do SIG permite ao usuário introduzir e modificar os arquivos de entrada do modelo, tanto espaciais como não espaciais, de maneira intuitiva e amigável. Já a base de dados interna é responsável por armazenar as entradas e as converter para um formato compatível com o SWAT, permitindo a execução das operações.

O SWAT baseia-se em uma estrutura de comandos para propagar o escoamento, sedimentos e agroquímicos pela bacia hidrográfica. Tal propagação é realizada através da determinação de parâmetros hidrológicos por meio da análise topográfica do terreno e das características da cobertura do solo. No processo de modelagem, a bacia é subdividida em sub-bacias menores conforme a necessidade do usuário, tendo como base a topografia do terreno. Por sua vez, cada sub-bacia é parametrizada através das Unidades de Resposta 
Hidrológica (Hydrologic Response Units - HRU’s), que compreendem uma única combinação de tipo de solo, uso da terra e declividade (NEITSCH et al., 2011). Subdividir a bacia em áreas contendo combinações únicas possibilita ao modelo refletir diferenças na evapotranspiração e outras condições hidrológicas para diferentes usos e solos. Desse modo, o escoamento, sedimentos e agroquímicos são calculados para cada HRU e propagados para obter os totais para cada sub-bacia. Tal processo aumenta a precisão das predições e fornece uma melhor descrição física dos componentes estudados, principalmente em casos onde a bacia possui alta heterogeneidade espacial (ARNOLD et al., 1998).

Independentemente do tipo de estudo realizado com o SWAT (vazão, sedimento, parâmetros de qualidade da água, agroquímicos, etc), o balanço hídrico é a força motora de todos os processos simulados na bacia hidrográfica. Desse modo, para diagnosticar precisamente a movimentação dos pesticidas, sedimentos ou nutrientes, é de fundamental importância que a simulação do ciclo hidrológico pelo modelo seja coerente com os processos ocorrentes na bacia hidrográfica (NEITSCH et al., 2011).

A simulação hidrológica realizada pelo SWAT pode ser separada em duas etapas principais. A primeira etapa corresponde à fase terrestre do ciclo hidrológico, onde se calcula a evapotranspiração potencial e real, o escoamento superficial, o deslocamento da água pelas camadas do solo, o fluxo de base, a produção de sedimentos, entre outros, para cada sub-bacia pré-definida pelo usuário. A segunda parte é denominada como fase de propagação ou roteamento, e está relacionada ao movimento de água e transporte de sedimentos, pesticidas, nutrientes, entre outros, através das vertentes e da rede de drenagem até o exutório da bacia (NEITSCH et al., 2011).

As entradas mínimas requeridas para simulação no SWAT se resumem a dados topográficos (Modelo Digital de Elevação), pedológicos, climáticos e de uso da terra. Os dados pedológicos consistem no mapa de solos e em dados físico-hídricos referentes aos tipos de solos presentes na área. De maneira análoga, os dados de uso e ocupação da terra constituem o mapa de uso da terra e dados referentes aos tipos de coberturas existentes. Já os dados climáticos requeridos são séries diárias de precipitação, temperatura, umidade relativa, velocidade do vento e radiação solar.

Ademais, outras informações adicionais podem ser inseridas no modelo conforme a necessidade do estudo e o grau de detalhamento desejado dos processos ocorrentes na bacia, como por exemplo, informações sobre o funcionamento de reservatórios, eventuais lançamentos nos corpos d'água, retiradas de água, informações sobre manejo de culturas, dentre outros. Tais informações são armazenadas e utilizadas pelo SWAT através de arquivos 
gerais alimentados pela interface ArcSWAT, os quais são gerados na etapa anterior à simulação. A Tabela 2 apresenta alguns destes arquivos gerais de entrada, junto a uma breve descrição das informações contidas nos mesmos. Conforme ressaltado, algumas destas informações são utilizadas para simular peculiaridades que não são comuns a todas as bacias hidrográficas, sendo de preenchimento opcional. Já outras informações são pré-definidas pelo modelo, devendo ser ajustadas pelo usuário com os dados próprios da bacia simulada, a exemplo das características dos solos e parâmetros climáticos.

Tabela 2 - Descrição dos principais arquivos gerais de entrada do modelo SWAT.

\begin{tabular}{ll}
$\begin{array}{l}\text { Designação } \\
\text { do arquivo }\end{array}$ & \multicolumn{1}{c}{ Breve descrição das informações contidas nos arquivos } \\
\hline.$c h m$ & Informações sobre as propriedades químicas do solo (nutrientes e pesticidas) \\
.$g w$ & $\begin{array}{l}\text { Propriedades que regem o movimento da água nos aquíferos raso e profundo } \\
\text { Informações sobre as operações de manejo (plantio, colheita, irrigação, aplicação de } \\
\text { nutrientes, pesticidas) }\end{array}$ \\
.$p n d$ & Propriedades das lagoas e wetlands \\
.$r e s$ & Informações sobre regras de operação de reservatórios \\
.$r t e$ & Características físicas da rede de drenagem relacionadas à propagação e roteamento \\
.$s o l$ & Propriedades físico-hídricas para cada camada do perfil de solo \\
.$w g n$ & Informações estatísticas necessárias para geração de dados climáticos diários \\
.$w u s$ & Informações sobre os usos consuntivos da água (retiradas para irrigação, uso urbano) \\
plant.dat & Informações sobre o crescimento vegetal referentes às coberturas presentes na bacia \\
pest.dat & Informações sobre a mobilidade e degradação dos pesticidas \\
fert.dat & Informações sobre o teor de nutrientes dos fertilizantes e adubos \\
recday.dat & Informações sobre fontes de poluição pontuais (cargas dos lançamentos) \\
\hline
\end{tabular}

Não obstante, o modelo SWAT ainda possui recursos que permitem ao usuário, na simulação dos processos hidrológicos, escolher os métodos de cálculo de acordo com a disponibilidade de dados. Como exemplos, podem ser citados o cálculo do escoamento superficial, que pode ser realizado através do método da Curva Número ou pelo método de Green-Ampt, e o cálculo da evapotranspiração potencial, no qual pode-se utilizar as equações de Hargreaves, Priestley-Taylor ou Penman-Monteith. Um maior detalhamento da parte hidrológica do modelo será apresentado nas próximas seções deste trabalho.

O SWAT vem sendo aplicado satisfatoriamente em bacias de diversas partes do mundo, permitindo a realização múltiplos estudos ambientais e gerando uma vasta literatura envolvendo o uso do modelo. Os trabalhos utilizando o simulador, em princípio, podem ser 
categorizados conforme o objeto central da simulação (vazão, sedimentos, qualidade da água, dentre outros) ou conforme o objetivo da simulação de cenários.

Independentemente do tipo de estudo, a simulação hidrológica é fundamental em todas as aplicações envolvendo o SWAT, visto que todos os demais processos ocorrentes nas bacias têm o ciclo hidrológico como principal força controladora. Em muitos trabalhos a simulação hidrológica é o foco principal do estudo, geralmente sendo acompanhada de metodologias para calibração gráfica e/ou estatística (comumente realizada para a vazão), sendo também relatados resultados de validação (GASSMAN et al., 2007). Um grande número de trabalhos com estas características foi realizado nos Estados Unidos, a exemplo do estudo conduzido por Arnold et al. (1999), que aplicaram o SWAT a 38 bacias com áreas entre $2250 \mathrm{~km}^{2} \mathrm{e}$ $304000 \mathrm{~km}^{2}$ localizadas no estado do Texas, com o objetivo de avaliar a capacidade do modelo em simular a hidrologia de grandes áreas. Cerucci e Conrad (2003) trabalharam em uma bacia de área de $36,8 \mathrm{~km}^{2}$ em Nova York e utilizaram o modelo para avaliar a eficácia de diferentes faixas de vegetação ripária na vazão dos cursos d'água, valendo-se também de técnicas de otimização binária para encontrar a configuração que melhor compatibilizasse custos e proteção ambiental. Green et al. (2006) realizaram simulações em uma bacia agrícola de Iowa $\left(8900 \mathrm{~km}^{2}\right)$, na qual mais de $80 \%$ da área é composta de sistemas de drenagem subsuperficial, com o objetivo de avaliar as predições hidrológicas do modelo em terrenos sob tais técnicas de manejo.

Alguns estudos de simulação hidrológica utilizando o SWAT também realizaram a calibração de outros elementos do ciclo hidrológico, como no trabalho de Kalin e Hantush (2006), em uma bacia de $98,8 \mathrm{~km}^{2}$ na Pensilvânia, onde foi realizada a calibração e validação do modelo para a vazão, escoamento superficial e escoamento de base com o objetivo de avaliar os impactos da urbanização sobre estes componentes. No trabalho de Tripathi et al. (2006) foi realizada a calibração para o escoamento superficial em uma bacia de $90,3 \mathrm{~km}^{2}$ localizada na Índia, com o objetivo de avalizar o efeito da subdivisão da bacia na simulação dos componentes hidrológicos. Já Adeogun et al. (2014) realizaram simulações de vazão e escoamento superficial em uma bacia com $12992 \mathrm{~km}^{2}$ situada no oeste da Nigéria, com o objetivo de avaliar a performance do modelo em gerar longas séries temporais em bacias de clima tropical.

Outras aplicações envolvendo o módulo de simulação hidrológica do SWAT incluem estudos de disponibilidade hídrica, a exemplo do trabalho de Gosain et al. (2005), onde os autores avaliaram os impactos no ciclo hidrológico, em especial no fluxo de retorno, após a introdução de um canal de irrigação em uma bacia no sudeste da Índia. Já Zeng e Cai (2014) 
utilizaram o modelo para simular os efeitos cumulativos do bombeamento de água subterrânea e da retirada de água para irrigação na vazão de uma bacia com extensão de 12690 km², situada nos estados do Colorado e do Kansas, nos Estados Unidos. Outro tipo de aplicação bastante comum em climas frios são as simulações tendo como foco a avaliação de processos relacionados ao degelo da neve, a exemplo dos estudos de Wang e Melesse (2006) e Levesque (2008).

Outra linha de estudos utilizando o SWAT tem se dedicado a predições relacionadas à produção, transporte e propagação de sedimentos pelos canais das bacias hidrográficas. Apesar da maior dificuldade em calibrar e validar estudos envolvendo sedimentos, ocasionada em grande parte devido à indisponibilidade e confiabilidade dos dados, existe na literatura um grande número de trabalhos desta natureza realizados em bacias de diferentes escalas. Mamo e Jain (2013) aplicaram o modelo em uma bacia de 1600 km² localizada na Etiópia visando simular a carga sólida do Rio Gumera, realizando também a simulação para a vazão. Parajuli, Mankin, Barnes (2008) aplicaram o SWAT em uma bacia com $950 \mathrm{~km}^{2}$ situada na região central dos Estados Unidos, com o intuito de avaliar a eficiência de faixas de vegetação marginal na retenção do aporte de sedimentos. Wu e Chen (2012) utilizaram o modelo na bacia do Rio Leste, na China, com o objetivo de simular as taxas de produção de sedimentos e o transporte através de carga sólida, gerando também estimativas a respeito da deposição líquida de sedimentos em alguns trechos do curso principal do Rio Leste.

Também são vários os estudos utilizando o SWAT para simulação de impactos por poluentes, onde os elementos simulados com maior frequência compreendem as diferentes formas de nitrogênio e fósforo, bactérias e alguns tipos de pesticidas. Bouraoui et al. (2005) utilizaram o modelo em uma bacia situada no extremo norte da Tunísia (área de 24000 km²), para simular vazão, sólidos suspensos, nitrato e ortofosfato, tendo como objetivo principal a avaliação dos impactos decorrentes de diferentes cenários de uso e manejo da terra. Gu, Sahu e Jha (2015) utilizaram o modelo com o objetivo de simular os impactos de culturas bioenergéticas na qualidade da água e sedimentos de uma bacia na região central dos Estados Unidos com 492000 km². Vazquez-Amabile, Engel e Flanagan (2006) realizaram aplicações em uma bacia agrícola do centro-leste dos Estados Unidos (área de $2800 \mathrm{~km}^{2}$ ) para avaliar as concentrações do herbicida atrazina na qualidade da água, com o objetivo principal de fomentar informações para futuras análises de risco. 
A simulação de cenários hipotéticos utilizando o SWAT tem se mostrado um método bastante promissor em estudos de avaliação de usos alternativos do solo e de implantação de boas práticas de manejo (BPMs) ${ }^{1}$ (GASSMAN et al., 2007). Santhi et al. (2006) realizaram simulações em uma bacia de área de $4554 \mathrm{~km}^{2}$ situada no norte do Texas, Estados Unidos, visando simular a efetividade da aplicação de BPMs na redução da produção de sedimentos e do aporte de nutrientes nos cursos d'água. A construção de cenários de BPMs foi realizada a partir da alteração de parâmetros e operações do modelo, sendo possível simular técnicas como a adoção de plantio direto, o plantio de culturas de cobertura, a readequação das taxas de aplicação de esterco e de fertilizantes, a inserção de faixas vegetativas, dentre outras. Já Kauffman et al. (2014) utilizaram o modelo para avaliar o efeito de 11 medidas de conservação do solo na disponibilidade de água e nas taxas de erosão de uma bacia do Kenia, tendo como objetivo principal da pesquisa a avaliação de serviços ecossistêmicos e suas relações de custo-benefício.

Outra linha de estudos que tem gerado um grande número de trabalhos nos últimos anos é a simulação dos impactos das mudanças climáticas em bacias hidrográficas. Segundo Gassman et al. (2007), os impactos da mudança do clima podem ser simulados no SWAT através de duas maneiras distintas. A primeira compreende alterações nos parâmetros do modelo relacionados às concentrações de $\mathrm{CO}_{2}$ atmosféricas, bem como seus efeitos no desenvolvimento das plantas e na transpiração. A segunda maneira, mais difundida, consiste na geração de séries climáticas representativas do clima futuro por meio de downscaling ${ }^{2}$ de projeções climáticas geradas por Modelos de Circulação Geral (GCMs), e sua posterior utilização como dado de entrada no SWAT. Van Liew, Feng e Pathak (2012) determinaram os impactos das mudanças climáticas na vazão, nitrogênio, fósforo e na produção de sedimentos em duas bacias do centro-norte dos Estados Unidos, com áreas de 1214 km² e 1990 km², para o período de 2040 a 2059. Para geração de cenários do clima futuro foram utilizados dados provenientes de diferentes GCMs nos cenários de baixas emissões (B1), médias emissões

\footnotetext{
${ }^{1}$ Best management practices (BMPs) é uma expressão amplamente utilizada nos Estados Unidos e Canadá para designar um conjunto de técnicas passíveis de serem implementadas visando à redução da poluição hídrica e à conservação dos solos.

${ }^{2}$ Uma das principais dificuldades dos estudos de mudanças climáticas em bacias hidrográficas deve-se à baixa resolução espacial dos Modelos de Circulação Geral da atmosfera, os quais não conseguem representar adequadamente os aspectos climáticos locais de pequenas áreas. Desse modo, torna-se necessária a realização de procedimentos de downscaling, ou redução de escala, visando o refinamento dos dados e a compatibilização das escalas de trabalho.
} 
(A1B) e altas emissões (A2) estabelecidos pelo Painel Intergovernamental sobre Mudanças Climáticas (IPCC).

Apesar de a maioria dos estudos envolvendo o SWAT serem realizados por instituições de cunho científico, o modelo também é utilizado por agências reguladoras de meio ambiente e órgãos tomadores de decisão, em especial nos Estados Unidos e na Europa. Nos Estados Unidos o modelo foi aplicado por agências estaduais e federais no projeto HUMUS (Hydrologic Unit Modeling of the United States), onde se buscou simular os processos hidrológicos e os impactos na qualidade da água decorrentes de captações para uso agrícola e urbano em 2149 unidades hidrológicas catalogadas pelo Serviço Geológico dos Estados Unidos (USGS) (JAYAKRISHNAN et al., 2005). O modelo também foi utilizado por agências no projeto CEAP (Conservation Effects Assessment Project) com o objetivo de quantificar os impactos ambientais dos programas conservacionistas implementados pelo Departamento de Agricultura dos Estados Unidos, tanto em escala nacional quanto regional (GASSMAN et al., 2007).

Ainda segundo Gassman et al. (2007), na Europa o SWAT tem sido utilizado por várias agências ligadas à Comissão Europeia, contribuindo em estudos de impactos hidrológicos provocados pela mudança climática, estudos de quantificação de nitrogênio e fósforo provindos de fontes de poluição não pontuais em corpos d'água continentais e zonas costeiras e em avaliações da eficiência dos planos integrados para conservação de recursos hídricos.

\subsection{O uso do SWAT no Brasil: principais dificuldades e limitações}

No Brasil, as aplicações do modelo SWAT tiveram início no final dos anos 90 e se consolidaram durante a década seguinte com a publicação de trabalhos em várias regiões do país. Grande parte destas aplicações é realizada em âmbito acadêmico, onde, geralmente, verifica-se a capacidade do modelo em representar adequadamente determinados componentes das bacias hidrográficas brasileiras.

Garbossa et al. (2011) e Bressiani et al. (2015) realizaram uma extensa revisão da literatura nacional envolvendo o simulador SWAT durante o período compreendido entre 1999 e 2015, na qual resultou em uma compilação com 102 trabalhos publicados no período. Os autores constataram que $48 \%$ dos trabalhos nacionais têm como foco principal as simulações de vazão, $36 \%$ tem seu foco em simulações de produção e transporte de 
sedimentos e apenas $9 \%$ em simulações de qualidade da água (nutrientes e/ou pesticidas) e demais componentes.

Entretanto, trabalhos publicados recentemente apontam a utilização do SWAT em novos tipos de estudo, ampliando e diversificando os nichos de aplicação do modelo no Brasil. Como exemplos, podem ser citados estudos de avaliação dos impactos das mudanças climáticas (PERAZZOLI; PINHEIRO; KAUFMANN, 2013; ARROIO JUNIOR; MAUAD, 2015), estudos de análise das alterações relacionadas às mudanças no uso da terra (PEREIRA et al., 2014; RODRIGUES et al., 2015; VILLELA, 2015; SILVA, 2016), de alterações relacionadas à implementação de boas práticas de manejo (ROCHA et al., 2012; STRAUCH et al., 2013), de utilização de dados de evapotranspiração obtidos por sensoriamento remoto (SOUSA et al., 2015), de projeções de disponibilidade hídrica com base em critérios de outorga (BRITTO et al., 2014), dentre outros.

Vários trabalhos nacionais relatam um bom ajuste entre dados observados e dados simulados após a etapa de calibração, indicando a capacidade do SWAT em representar satisfatoriamente alguns aspectos das bacias brasileiras. Entretanto, muitos destes estudos relatam dificuldades e apontam algumas limitações do modelo, dentre as quais podem ser citadas: a relativa dificuldade de obtenção de dados de entrada e de séries observadas para calibração; a complexidade na seleção de parâmetros apropriados para calibrar o modelo e a subjetividade na escolha de valores para estes parâmetros e as deficiências e limitações em alguns dos algoritmos das rotinas de modelagem, as quais se mostram inadequadas para representação de determinados processos em bacias brasileiras. As seções seguintes do texto serão dedicadas à discussão de alguns destes pontos.

\subsubsection{Considerações sobre a disponibilidade, precisão e escala dos dados de entrada requeridos pelo SWAT}

Segundo Bressiani et al. (2015), muitos estudos reportam dificuldades na aplicação do SWAT no Brasil devido à problemas como: indisponibilidade de dados; dificuldade de acesso a determinados acervos de informações, em especial junto à instituições privadas; e problemas relacionados ao processamento e preparação dos dados para sua posterior utilização no modelo. Segundo os autores, grande parte dos dados atualmente disponíveis carece de organização, muitas vezes não sendo acessíveis através de bases de dados centralizadas ou estando disponíveis apenas em formatos que não são facilmente utilizáveis, requerendo tempo 
e esforço do usuário nas etapas de preparação e conversão para os formatos de entrada exigidos pelo modelo.

Um aspecto relevante em relação à disponibilidade de dados para utilização do SWAT no Brasil refere-se à distribuição espacial das informações hidrometeorológicas existentes no país. A Organização Mundial de Meteorologia (OMM) em seu Guia de Instrumentação Meteorológica e Métodos de Observação (WMO, 2008) reúne recomendações quanto às densidades mínimas de redes de estações hidrometeorológicas conforme o tipo de unidade fisiográfica, sendo compiladas na Tabela 3. Tais valores são critérios genéricos, os quais podem ser utilizados como parâmetros de avaliação das redes hidrológicas de determinado território.

Tabela 3 - Recomendações de densidade mínima por tipo de estação para redes hidrometeorológicas $\left(\mathrm{km}^{2}\right.$.estação $\left.{ }^{-1}\right)(\mathrm{WMO}, 2008)$.

\begin{tabular}{|c|c|c|c|c|c|}
\hline \multirow{2}{*}{$\begin{array}{l}\text { Unidades } \\
\text { Fisiográficas }\end{array}$} & \multicolumn{2}{|c|}{ Precipitação } & \multirow{2}{*}{ Vazão } & \multirow{2}{*}{ Sedimentos } & \multirow{2}{*}{$\begin{array}{c}\text { Qualidade } \\
\text { da água }\end{array}$} \\
\hline & Pluviômetro & Pluviógrafo & & & \\
\hline $\begin{array}{l}\text { Litoral / Região } \\
\text { Costeira }\end{array}$ & 900 & 9.000 & 2.750 & 18.300 & 55.000 \\
\hline Montanhas & 250 & 2.500 & 1.000 & 6.700 & 20.000 \\
\hline $\begin{array}{l}\text { Planícies } \\
\text { Interioranas }\end{array}$ & 575 & 5.750 & 1.875 & 12.500 & 37.500 \\
\hline $\begin{array}{l}\text { Ondulada / } \\
\text { Montanhosa }\end{array}$ & 575 & 5.750 & 1.875 & 12.500 & 47.500 \\
\hline Ilhas $\left(<500 \mathrm{~km}^{2}\right)$ & 25 & 250 & 300 & 2.000 & 6.000 \\
\hline Áreas Urbanas & - & 10 a 20 & - & - & - \\
\hline
\end{tabular}

De acordo com o relatório Conjuntura dos Recursos Hídricos no Brasil (ANA, 2013), o país possuía em 2013 um total de 8.627 estações pluviométricas em operação catalogadas na Rede Hidrometeorológica Nacional, a qual engloba tanto as estações operadas pela ANA quanto as operadas pelas unidades federativas. Tal número equivale a uma densidade média nacional de 1 pluviômetro a cada $987 \mathrm{~km}^{2}$, valor fora da densidade mínima de recomendada pela OMM independentemente de qual seja a unidade fisiográfica considerada. Para fins comparativos, os Estados Unidos possuem uma densidade média de 1 pluviômetro a cada 384 km² (USDC-NOAA, 2013), enquanto na França a densidade é de 1 pluviômetro a cada 230 $\mathrm{km}^{2}$ (MOUNIER et al., 2012). 
Ainda de acordo com o relatório da ANA, a análise da densidade de estações pluviométricas por região brasileira revela que existem desigualdades regionais e que as menores densidades situam-se na Região Norte (4.000 km².estação $\left.{ }^{-1}\right)$ e parte da Região Centro-Oeste $\left(2.600 \mathrm{~km}^{2}\right.$.estação $\left.{ }^{-1}\right)$, enquanto no Sudeste ocorre uma densidade próxima de $500 \mathrm{~km}^{2}$.estação ${ }^{-1}$. Tal desigualdade é devida principalmente aos problemas de acessibilidade e ao elevado custo de logística envolvido, como é o caso, por exemplo, das Bacias Amazônica e do Alto Paraguai (ANA, 2013).

Além da questão da distribuição espacial, cumpre ressaltar a importância da existência de séries hidrológicas representativas em termos de sua extensão temporal. Conforme a publicação da Organização Meteorológica Mundial (OMM), séries de dados pluviométricos e fluviométricos são consideradas confiáveis/representativas quando possuem, no mínimo, 30 anos de dados. É evidente, entretanto, que quanto maior o período de registros, mais confiáveis tendem a ser as estimativas geradas a partir destes dados. Segundo a ANA (2013), cerca de $60 \%$ das estações pluviométricas por ela monitoradas apresentam séries com mais de 30 anos de registros, com a extensão das séries variando de uma média de 23 anos para a região Norte a uma média de 54 anos para a região Sudeste.

Outra questão pertinente em relação aos dados de entrada do SWAT é a precisão e o nível de detalhamento das informações espaciais básicas requeridas pelo modelo (MDE, mapa de solos e mapa de uso da terra). É grande o número de trabalhos na literatura, tanto nacional quanto internacional, avaliando os efeitos da variação da resolução espacial destas entradas no processo de modelagem. Em geral, tais estudos reportam que o modelo apresenta uma melhor performance quando são utilizados dados especiais de alta resolução.

A princípio, a resolução espacial do MDE deve ser detalhada o suficiente para representar adequadamente a variabilidade topográfica presente na bacia. Entretanto, pesquisas apontam que em simulações em bacias hidrográficas com índices de pluviosidade anuais superiores a $1200 \mathrm{~mm}$, é aconselhável a utilização de informações espaciais de alta resolução, independentemente da morfologia do terreno (CHAPLOT, 2014). Além disso, estudos relatam que os componentes simulados pelo SWAT possuem diferentes sensibilidades em relação à resolução espacial do MDE. A utilização de grades de baixa resolução não afetou significativamente os resultados de vazão, porém teve grande impacto nas simulações de sedimentos e de qualidade da água, gerando predições subestimadas (CHAPLOT, 2005; LIN et al., 2010; GHAFFARI , 2011).

Atualmente, o mapeamento topográfico sistemático do país, cujas cartas são editadas e publicadas pelo Instituto Brasileiro de Geografia e Estatística (IBGE), possui 99,3\% do 
território nacional mapeado em escala 1:250.000, 67,7\% mapeado na escala de 1:100.000, $13 \%$ na escala 1:50.000 e apenas $1 \%$ em escala 1:25.000. Além de não apresentarem continuidade em todo território nacional, grande parte destas cartas encontram-se desatualizadas, visto que tiveram sua última atualização nas décadas de 1970 e 1980 (CAMBOIN et al., 2008).

Nesse contexto, tendo em vista a escassez de levantamentos topográficos detalhados no país, é grande o número de trabalhos de modelagem hidrológica utilizando dados altimétricos provenientes de sensores orbitais, como os fornecidos pelo projeto Shuttle Radar Topography Mission (SRTM), divulgados na resolução de 3 arco-segundos (90m). Outros trabalhos utilizam os produtos disponibilizados pelo projeto TOPODATA, sob execução do Instituto Nacional de Pesquisas Espaciais (INPE), os quais são elaborados a partir dos dados SRTM e refinados da resolução espacial original de 3 arco-segundos (90m) para a resolução de 1 arco-segundo (30m) por meio de krigagem. Somente a partir do ano de 2014 a NASA passou a disponibilizar os dados SRTM em escala original de $30 \mathrm{~m}$ para todo o território brasileiro, ampliando as possibilidades de trabalho em bacias de menor extensão.

De maneira semelhante aos dados altimétricos, existe no Brasil uma grande carência de mapeamentos detalhados que possam descrever adequadamente a variabilidade dos solos em pequenas extensões, limitando a aplicação dos modelos hidrológicos em pequenas bacias. Cobrindo todo o território, tem-se o mapeamento em nível exploratório do Projeto RADAMBRASIL, em escala 1:1.000.000, bem como mapeamentos estaduais em nível de reconhecimento, com escalas variando entre 1:100.000 e 1:600.000. Apenas cerca de 0,25\% do território nacional conta com mapas em níveis semidetalhado (escala 1:20.000 a 1:100.000) e detalhado (escala $\geq 1: 20.000$ ). Dentre as regiões com levantamentos semidetalhados, destacam-se as quadrículas de alguns setores do Estado de São Paulo levantadas pelo Instituto Agronômico de Campinas (IAC), e levantamentos detalhados executados por instituições de pesquisas, universidades e outras organizações em vários pontos do país (SANTOS; SANTOS, 2007).

A título de comparação, o território dos Estados Unidos é coberto por dois mapeamentos pedológicos distintos, ambos integrados à base de dados do SWAT: o State Soil Geographic (STATSGO), em escala 1:250.000, sendo utilizado em aplicações de grande extensão, e o Soil Survey Geographic (SSURGO), em escalas variando de 1:12.000 a 1:63.000, utilizado em projetos menores. Além disso, a base de dados americana também inclui valores para todos os parâmetros pedológicos necessários pelo simulador, referentes a cada classe pedológica presente nos levantamentos. 
Tal carência de levantamentos pedológicos em grande escala, bem como a ausência de uma base de dados centralizada com valores de referência para os atributos pedológicos dos solos brasileiros, resultam na necessidade de realizar parametrizações teóricas para aplicação do SWAT no Brasil. Conforme aponta Bressiani et al. (2015), um exemplo de tais parametrizações é o uso de funções de pedo-transferência, as quais permitem estimar propriedades hidrodinâmicas dos solos a partir de suas propriedades e parâmetros básicos, os quais são encontrados com maior facilidade nos levantamentos existentes.

\subsubsection{Considerações sobre a disponibilidade de dados para calibração e validação do SWAT no Brasil}

O levantamento realizado por Bressiani et al. (2015) constatou que 66\% dos 102 estudos nacionais utilizando o SWAT realizaram a calibração dos resultados, enquanto apenas 23\% avançaram até a etapa de validação. Dentre estes estudos que apresentaram os resultados referentes à calibração/validação, os autores ainda constataram que mais de $70 \%$ deles utilizaram séries históricas inferiores a cinco anos de dados.

Não existem na literatura diretrizes gerais recomendando um intervalo mínimo de dados necessários para realização das etapas de calibração e validação no SWAT (ARNOLD et al., 2012b). Visando avaliar a sensibilidade das predições de vazão em relação ao tamanho da série utilizada na calibração, Yapo et al. (1996) utilizaram diferentes períodos de dados, constatando que foi necessário um período mínimo de oito anos para obter resultados satisfatórios. Entretanto, deve-se ressaltar que este período é uma especificidade de cada projeto, sendo recomendável que as séries compreendam tanto períodos de seca quanto períodos chuvosos, bem como registrem a ocorrência de eventos extremos e mudanças significativas na bacia.

O número relativamente baixo de estudos reportando a calibração e validação do SWAT no Brasil, bem como a utilização de curtos períodos de tempo em trabalhos que realizam estas etapas, confirma a baixa disponibilidade de dados para estudos em hidrologia e recursos hídricos disponíveis no país, tanto em escala temporal como espacial, conforme discutido anteriormente.

Atualmente, a rede fluviométrica sob responsabilidade da Agência Nacional de Águas (ANA) contém 5.275 estações fluviométricas cadastradas em todo território nacional, o que implica em uma estação fluviométrica a cada 1.614 km². A título de comparação, os Estados Unidos possuem em sua rede fluviométrica operada pelo Serviço Geológico dos Estados 
Unidos (USGS) um total de 9.322 estações fluviométricas, resultando em uma estação a cada $1.057 \mathrm{~km}^{2}$ (HIRSCH; FISHER, 2014). Apesar de possuir uma quantidade razoável de estações fluviométricas, o Brasil ainda carece de informações hidrológicas, visto que a distribuição destas é bastante desigual entre as regiões brasileiras: o Sudeste possui a maior densidade de estações do país, com uma estação a cada $484 \mathrm{~km}^{2}$, enquanto a região Norte apresenta uma estação a cada $8.557 \mathrm{~km}^{2}$.

A dificuldade de obtenção de dados para calibração do modelo é ainda mais acentuada em estudos focados na simulação de sedimentos e qualidade da água. Segundo a publicação Evolução da Rede Hidrometeorológica Nacional (ANA, 2007), o Brasil possuía no referido ano 736 estações sedimentométricas, o que equivale a uma densidade de 1 estação a cada $11.570 \mathrm{~km}^{2}$. Com relação à qualidade da água, totalizavam naquele ano 2.241 estações, indicando uma densidade de 1 estação a cada $3.800 \mathrm{~km}^{2}$. Apesar do número elevado de estações, o monitoramento é feito de forma dispersa e não padronizada. Algumas redes estaduais de monitoramento são bastante abrangentes, com coletas frequentes e medição de diversos parâmetros, enquanto outras apresentam apenas uma coleta no ano e medem poucas variáveis, ocasionando a ausência de séries históricas longas e consistentes (ANA, 2013).

\subsubsection{Limitações em alguns dos algoritmos do SWAT para uso em bacias brasileiras}

As limitações envolvendo o uso do SWAT no Brasil não se restringem apenas à disponibilidade de dados de entrada e dados para calibração do modelo. Vários trabalhos relatam deficiências e limitações intrínsecas às rotinas de modelagem, apontando algoritmos e parâmetros não adequados para representar determinados processos. Conforme sinalizado por Strauch e Volk (2013), ainda que um grande número de estudos apresente simulações com calibrações consideradas boas ou satisfatórias para a vazão e/ou sedimentos, tais resultados não garantem necessariamente que os demais processos ocorrentes na bacia hidrográfica estejam sendo simulados corretamente.

Nesse sentido, vários trabalhos realizados no Brasil expõem imprecisões nas estimativas de alguns componentes-chave do ciclo hidrológico, como evapotranspiração, escoamento superficial e na contribuição subterrânea para o canal. Em geral, é relatada a subestimativa da evapotranspiração anual e a superestimava das parcelas de fluxo lateral e fluxo de retorno, ambas responsáveis pela contribuição subterrânea para o corpo hídrico. Desse modo, observa-se um excesso de água na fase terrestre do ciclo hidrológico devido à 
menor retirada de água por evapotranspiração, o que ocasiona a superestimativa de vazão observada em um grande número de trabalhos, mesmo após a etapa de calibração do modelo.

A evapotranspiração varia em função de elementos meteorológicos como temperatura, umidade relativa do ar, radiação solar e velocidade do vento, além das características e condições de umidade do solo e do estado hídrico da planta (LEMON et al., 1957). Quanto maior a disponibilidade de energia solar, temperatura e velocidade do vento e menor a umidade relativa do ar, maior deverá ser a demanda evaporativa da atmosfera, ocasionando aumento na taxa de evapotranspiração quando a umidade do solo não for fator restritivo (LIMA, 2010). Desse modo, em países com condições climáticas como as do Brasil, parte significativa precipitação pluviométrica é transferida para a atmosfera na forma de vapor, resultando em elevados valores de evapotranspiração. Segundo estimativa realizada por Tucci (2009), em bacias rurais das regiões Sul e Sudeste do Brasil a evapotranspiração corresponde a cerca de $68 \%$ do total anual precipitado.

Na Figura 2 é apresentada uma estimativa da evapotranspiração global anual média para o período entre 2000 e 2006 obtida por sensoriamento remoto a partir do sensor MODIS, a bordo do satélite AQUA, operado pelo programa Earth Observing System (EOS) da NASA. Verifica-se que na região Amazônica encontram-se os maiores valores de evapotranspiração do país, variando entre 1.250 e $1.500 \mathrm{~mm}^{-\mathrm{ano}^{-1}}$, enquanto os menores valores ocorrem no semiárido nordestino e no Planalto Central, variando entre 500 e 750 mm.ano ${ }^{-1}$. Na região Sudeste predominam valores próximos a $1.000 \mathrm{~mm} \cdot \mathrm{ano}^{-1}$.

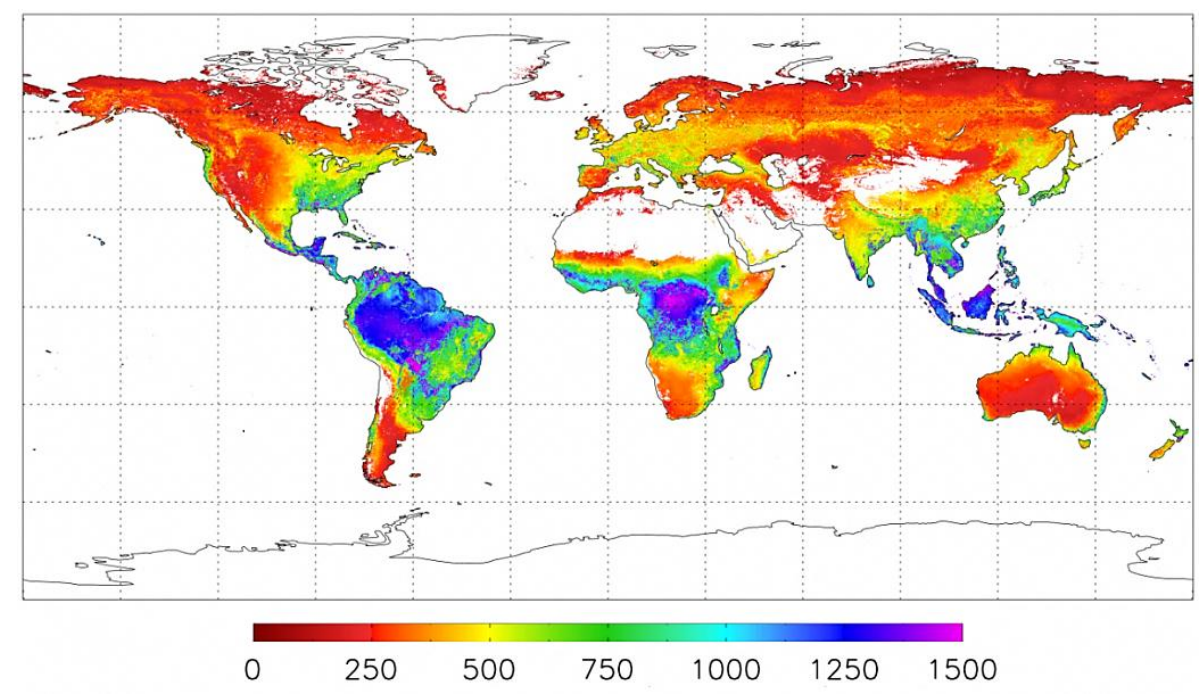

Figura 2 - Estimativa da evapotranspiração global anual obtida pelo sensor MODIS/AQUAEOS da NASA para o período entre 2000 e $2006\left(\mathrm{~mm}_{\mathrm{ano}}{ }^{-1}\right)$. 
Grande parte dos modelos hidrológicos utilizados atualmente, incluindo os predecessores que deram origem ao SWAT, foi desenvolvida em centros de pesquisa localizados nos Estados Unidos e na Europa. Verifica-se que nestas regiões há o predomínio

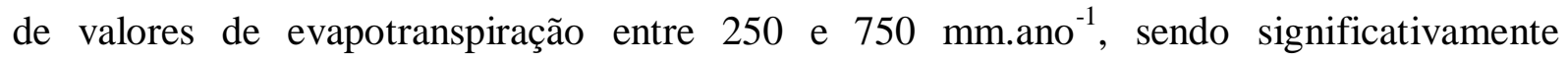
inferiores aos valores ocorrentes nas regiões de menor latitude. Tendo como base estas estimativas globais apresentadas, verifica-se que diversas simulações realizadas em bacias brasileiras geraram valores de evapotranspiração considerados inferiores aos que seriam esperados, sugerindo uma possível limitação dos algoritmos do SWAT em quantificar adequadamente tal parcela do ciclo hidrológico.

No trabalho de Melo Neto (2013) o SWAT foi aplicado a duas bacias localizadas no sul de Minas Gerais, com áreas de $32 \mathrm{~km}^{2}$ e 4,7 km². Visando avaliar os componentes do balanço hídrico, o estudo foi realizado para diferentes discretizações quanto ao número de sub-bacias e número de camadas do perfil de solo. Para avaliação da evapotranspiração, os totais anuais simulados pelo modelo foram comparados com estimativas obtidas por meio de balanço hídrico simples. Em todas as simulações, independentemente do nível de discretização adotado, a evapotranspiração anual simulada pelo SWAT foi subestimada quando comparada com os valores estimados por balanço hídrico simples, com desvios variando entre $-3,8 \%$ e $-38,5 \%$. Segundo o autor, uma possível justificativa para esse fato pode ser a dificuldade que o modelo tem em expressar a retirada de água do solo para atender a demanda evaporativa, promovendo como compensação a redução da evapotranspiração real ocorrida no período.

Na simulação realizada por Castro (2013) o modelo foi aplicado à Bacia do Alto Rio Jardim, a qual possui 105 km² de extensão e localiza-se no Distrito Federal. Dos $1.113 \mathrm{~mm}$ de chuva anuais na bacia, $447 \mathrm{~mm}$ (cerca de $40 \%$ do total precipitado) foram convertidos em evapotranspiração, pouco mais da metade do valor que seria esperado em comparação com valores de referência medidos experimentalmente em outros trabalhos na região. Além disso, os valores simulados superestimaram a parcela de escoamento superficial e subestimaram o fluxo de base. Com os ajustes da calibração, a evapotranspiração passou a $576 \mathrm{~mm}$ (51\% do total precipitado), valor ainda inferior ao obtido experimentalmente em outros estudos na região (cerca de $70 \%$ ).

No trabalho realizado por Bonumá (2011), o SWAT foi aplicado à bacia agrícola do Arroio Lino, situada no Rio Grande do Sul, com área de 4,8 $\mathrm{km}^{2}$. Na avaliação do balanço hídrico gerado pelo modelo durante o período de calibração, dos $1613 \mathrm{~mm}$ anuais de precipitação medidos, 545 foram convertidos em evapotranspiração (cerca de $34 \%$ do total 
precipitado). Já ao considerar-se apenas o período de validação, a evapotranspiração real correspondeu a $41 \%$ da precipitação anual total.

Em simulação realizada na bacia do Rio Preto $\left(1.000 \mathrm{~km}^{2}\right.$ de extensão), localizada no Planalto Norte Catarinense, Bonumá et al. (2013) apresentam estimativas para o balanço hídrico entre os anos de 1990 a 2009 obtidas com o SWAT. Dos 1675 mm anuais de precipitação medida, $769 \mathrm{~mm}$, ou seja, cerca de $46 \%$, são perdidos por evapotranspiração na bacia, havendo forte variação de ano para ano durante o período analisado. Assim como em outros trabalhos, a parcela de escoamento superficial teve grande representatividade no balanço hidrológico.

Santos (2014) realizou simulações em uma sub-bacia do Rio Arapepó, localizada no nordeste do Pará, com área total de 7,68 $\mathrm{km}^{2}$. No trabalho, a autora apresenta os valores simulados para alguns componentes do ciclo hidrológico de uma das sub-bacias após a calibração do modelo. A precipitação média anual entre os anos de 2008 e 2015 totalizou $1.976 \mathrm{~mm}$, dos quais apenas $195 \mathrm{~mm}$, cerca de 10\%, foram convertidos em evapotranspiração. É ressaltado que as estimativas de evapotranspiração mostram maior deficiência nos períodos secos, sendo sugerida a utilização de outros métodos de cálculo.

Diante deste contexto, alguns trabalhos propuseram diferentes abordagens de modo a obter estimativas hidrológicas mais realistas com o SWAT. Sousa (2010) estimou a evapotranspiração a partir de imagens orbitais através do modelo SEBAL/METRIC para ser utilizada como dado de entrada na simulação hidrológica do SWAT, substituindo os métodos de cálculo originalmente presentes no modelo. O estudo foi realizado em uma bacia de 6.000 km² situada no leste da Amazônia legal, entre os anos de 2003 e 2006. A evapotranspiração diária estimada pelo modelo SEBAL/METRIC mostrou concordância com resultados obtidos a partir de medições realizadas em uma torre micrometeorológica situada na área, permitindo sua utilização na simulação hidrológica. Inicialmente, foi realizada uma simulação utilizandose o método de Penman-Monteith do SWAT, o qual gerou uma evapotranspiração acumulada subestimada em 45\% em relação aos dados observados (medidos). Já na aplicação do modelo com assimilação da evapotranspiração obtida por sensoriamento remoto foi obtida uma evapotranspiração acumulada $25 \%$ menor do que o observado, evidenciando uma melhoria na simulação. As modificações no modelo também repercutiram em uma melhoria significativa das simulações de vazão, com uma redução no erro superestimado em $13 \%$ para uma subestimativa de $3 \%$ na vazão diária.

Silva (2013) utilizou o SWAT na avaliação de serviços ecossistêmicos em duas bacias localizadas na porção centro-oeste do Estado de São Paulo, com áreas de 12.400 km² e 12 
$\mathrm{km}^{2}$, de modo a avaliar os efeitos de diferentes cenários de reflorestamento das Áreas de Preservação Permanente. No trabalho, foi implementada diretamente no código fonte do SWAT uma função para prescrever o índice de área foliar (IAF) sazonalmente para diferentes vegetações. Tal índice influencia diretamente o cálculo da evapotranspiração potencial pelo método de Penman-Monteith e a interceptação da precipitação pelo dossel, que posteriormente será evaporada e contabilizada no cálculo da evapotranspiração real. A calibração do modelo modificado foi realizada para a fração evaporativa média nas HRUs e para a vazão, obtendo resultados considerados de satisfatórios a bons. Dentre as melhorias observadas, o autor aponta uma distribuição mais realista dos três componentes responsáveis pela evapotranspiração no modelo (transpiração, evaporação do solo e evaporação da precipitação interceptada no dossel das plantas).

De acordo com Strauch e Volk (2013), uma das principais deficiências da aplicação do SWAT em regiões tropicais diz respeito às rotinas de crescimento das culturas perenes, visto que estas, a princípio, foram desenvolvidas para regiões temperadas. Para determinar os ciclos anuais de crescimento das árvores e das plantas perenes, o modelo baseia-se no período de dormência (período no qual não há crescimento vegetal), o qual não ocorre em regiões tropicais devido à menor amplitude do fotoperíodo ao longo do ano. Visando contornar tal limitação, os autores modificaram as rotinas de simulação referentes ao crescimento vegetal de modo a implementar um limiar de umidade do solo que automaticamente aciona novos ciclos de crescimento para plantas perenes através da transição da estação seca para a estação chuvosa. Visando testar as modificações propostas, os autores realizaram simulações para uma bacia de $234 \mathrm{~km}^{2}$ do bioma Cerrado, localizada no Distrito Federal. Para avaliar as modificações no modelo, foram realizadas calibrações para a evapotranspiração e para o índice de área foliar utilizando-se dados obtidos por sensoriamento remoto. Os resultados obtidos mostraram que as modificações no SWAT conseguiram representar razoavelmente a dinâmica sazonal da bacia, aprimorando não somente a modelagem do crescimento vegetal, mas também o ciclo hidrológico, obtendo estimativas de evapotranspiração mais próximas da realidade da bacia. 


\section{PROCEDIMENTOS METODOLÓGICOS}

Nesta seção é inicialmente apresentada uma breve descrição das características físicas das bacias hidrográficas selecionadas como estudos de caso para realização das simulações com o SWAT (item 4.1). Em seguida, as rotinas de simulação hidrológica do modelo são descritas com maior detalhamento, dando maior ênfase nas estruturas relacionadas à determinação da evapotranspiração e de crescimento vegetal (item 4.2). Nas seções seguintes são descritos os procedimentos de obtenção de dados de entrada e as configurações adotadas nas simulações iniciais, onde mantiveram-se as configurações padrão (default) do SWAT (item 4.3), bem como são descritas as modificações propostas para melhoria da simulação hidrológica (item 4.4). Posteriormente, são apresentados os procedimentos adotados na calibração e validação do modelo para a vazão (item 4.5), bem como são detalhados métodos para estimar a evapotranspiração anual nas bacias estudadas, visando sua comparação com os dados simulados (item 4.6).

\subsection{Descrição das bacias selecionadas para simulação no SWAT}

Foram selecionadas cinco bacias hidrográficas de diferentes tamanhos situadas no estado de São Paulo para realização das simulações propostas neste trabalho. O critério determinante para a escolha destas bacias foi a disponibilidade de dados - não somente climáticos e fluviométricos - mas também em relação à existência de mapeamentos topográficos e pedológicos em níveis de detalhamento compatíveis com as áreas das bacias. Além disso, optou-se por não utilizar bacias adjacentes ou próximas umas às outras, de forma a selecionar áreas com certa singularidade, porém que ainda apresentassem um contexto climático, pedológico e de uso da terra semelhante. Ademais, a seleção de bacias não adjacentes permitiu que os dados e informações de entrada fossem obtidos a partir de fontes distintas, garantindo que as simulações fossem realizadas em diferentes escalas espaciais.

Na Tabela 4 são exibidas informações básicas sobre as bacias selecionadas nesta pesquisa, sendo apresentada a designação adotada no decorrer do texto (B1 a B5), o nome do curso d'água principal, a área da bacia, a Unidade de Gerenciamento de Recursos Hídricos (UGRHI) e os respectivos municípios nas quais se inserem e o período de dados disponíveis para as simulações. 
Tabela 4 - Informações gerais sobre as bacias selecionadas neste trabalho.

\begin{tabular}{|c|c|c|c|c|c|}
\hline $\mathbf{N}^{\circ}$ & Curso principal & $\begin{array}{l}\text { Área } \\
\left(\mathbf{k m}^{2}\right)\end{array}$ & UGRHI & Município(s) & $\begin{array}{c}\text { Período de } \\
\text { dados }\end{array}$ \\
\hline B1 & Córrego Cana-do-Reino & 42 & 18 & Votuporanga & $2002-2014$ \\
\hline B2 & Ribeirão do Feijão & 242 & 13 & São Carlos, Analândia e Itirapina & $1980-2007$ \\
\hline B3 & Ribeirão do Mandaguari & 740 & 21 & $\begin{array}{c}\text { Presidente Prudente, Caiabu, } \\
\text { Indiana, Regente Feijó e } \\
\text { Martinópolis }\end{array}$ & $1995-2009$ \\
\hline B4 & Rio do Pari & 1024 & 17 & $\begin{array}{l}\text { Assis, Echaporã, Platina, } \\
\text { Campos Novos Paulista, } \\
\text { Cândido Mota e Palmital }\end{array}$ & $1994-2013$ \\
\hline B5 & $\begin{array}{l}\text { Rio Paranapanema (Alto } \\
\text { Curso) }\end{array}$ & 5959 & 14 & $\begin{array}{c}\text { Itapetininga, Angatuba, Campina } \\
\text { do Monte Alegre, Buri, Capão } \\
\text { Bonito, Ribeirão Grande, São } \\
\text { Miguel Arcanjo, Sarapuí, Pilar } \\
\text { do Sul, Tapiraí e Piedade }\end{array}$ & $1992-2012$ \\
\hline
\end{tabular}

Na Figura 3 é apresentado o mapa com a localização geográfica destas bacias no estado de São Paulo. Um maior detalhamento sobre a caracterização do meio físico de cada uma delas é exposto a seguir.

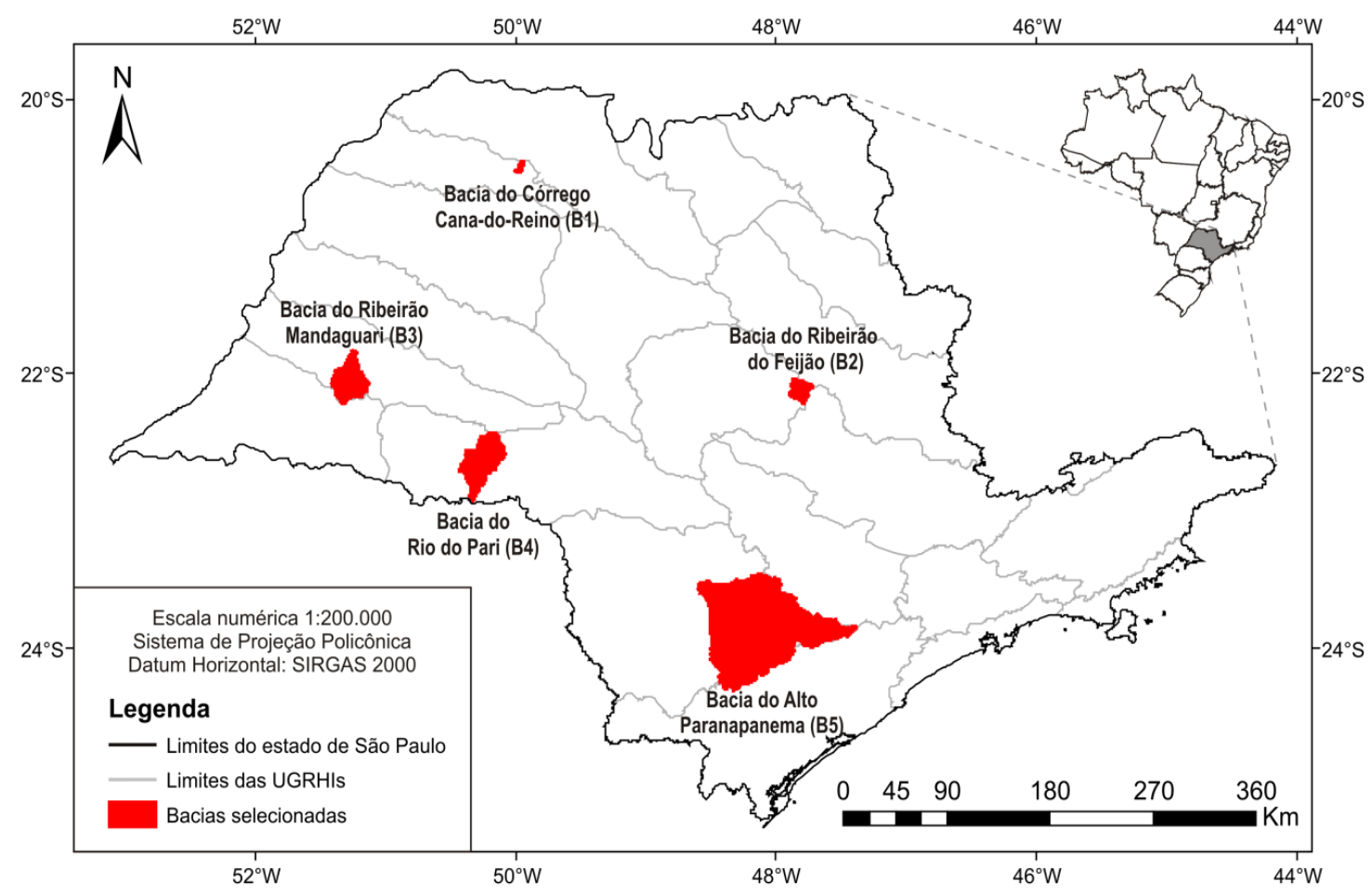

Figura 3 - Localização geográfica das bacias selecionadas neste estudo. 


\section{Bacia B1: Córrego Cana-do-Reino}

Localizada no noroeste do estado de São Paulo, nos domínios do município de Votuporanga, a bacia do Córrego Cana-do-Reino compreende uma área de aproximadamente $42,1 \mathrm{~km}^{2}$. O córrego possui um total de $12,5 \mathrm{~km}$ de extensão, tendo seu deságue no Córrego do Cabrito, o qual por sua vez é afluente da margem direita do Rio São José dos Dourados. Desse modo, a bacia está inserida na Unidade de Gerenciamento de Recursos Hídricos 18 São José dos Dourados.

A bacia do Córrego Cana-do-Reino apresenta uma elevação média de $469 \mathrm{~m}$ e amplitude altimétrica de $135 \mathrm{~m}$, com cotas variando entre 405 e $540 \mathrm{~m}$, conforme apresentado na Figura 4. A declividade média da bacia é de 6,2\%, com mais de $57 \%$ de sua área apresentando declives na faixa de "3 a 8\%", o que permite a classificação do relevo em suaveondulado conforme classificação proposta pela EMBRAPA (1979).

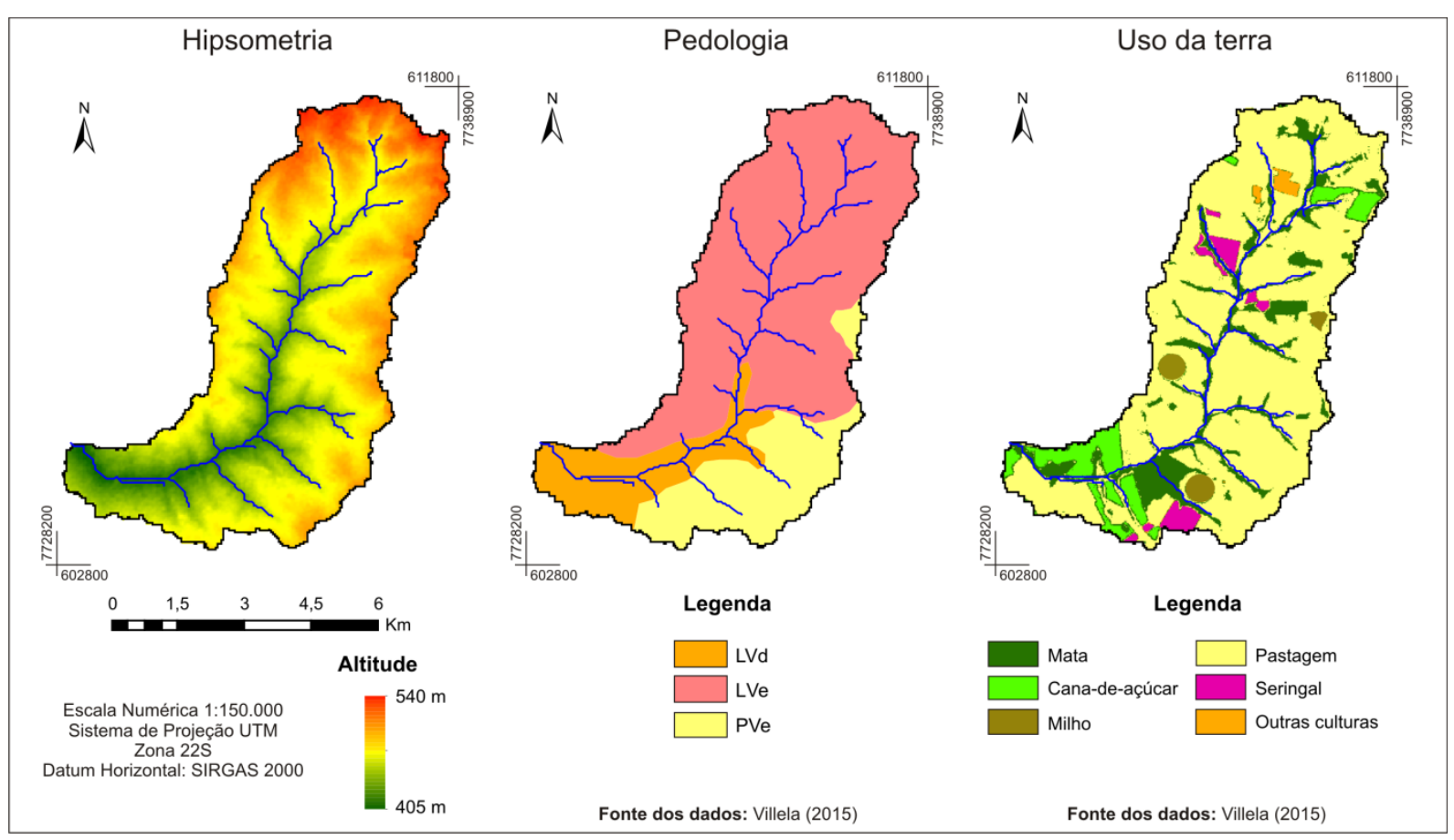

Figura 4 - Caracterização física da bacia do Córrego Cana-do-Reino.

Segundo a subdivisão geomorfológica do Estado de São Paulo proposta por Almeida (1964), a qual divide o estado em cinco grandes províncias geomorfológicas, a região da bacia do Córrego Cana-do-Reino está inserida na província do Planalto Ocidental. Já com relação ao sistema de relevo, a unidade dominante na bacia são as Colinas Médias, possuindo como principais características interflúvios com áreas de 1 a $4 \mathrm{~km}^{2}$, topos aplainados e vertentes 
com perfis convexos a retilíneos. A drenagem apresenta média a baixa densidade, com padrão sub-retangular, os vales são abertos a fechados e há presença de planícies aluviais interiores restritas (IPT, 1981).

Em relação à geologia, de acordo com o levantamento geológico executado por Perrotta et al. (2005), a unidade litoestratigráfica dominante na área corresponde à Formação Vale do Rio do Peixe. Tal formação é composta predominantemente de arenitos muito finos a finos, com coloração marrom, rosa e alaranjada, além de camadas tabulares de siltito maciço, de cores creme e marrom, bem como lentes de arenito conglomerático com intraclastos argilosos ou carbonáticos.

Os solos predominantes na área de estudo, de acordo com o levantamento pedológico detalhado realizado por Villela (2015), apresentado na Figura 4, constituem os Latossolos Vermelhos Eutróficos (LVe), ocorrendo em 65,2\% da área, e Latossolos Vermelhos Distróficos ( $\mathrm{LVd}$ ), aflorando em 14,4\% do território. Há também a ocorrência de uma faixa de Argissolos Vermelhos Eutróficos (PVe) na porção sudeste da bacia, ocupando uma área de cerca de $20,4 \%$.

O uso da terra na bacia é voltado principalmente para pecuária, com a presença de pastagens em 71,2\% da área. As superfícies de vegetação densa, representadas por Áreas de Preservação Permanente e Reserva Legal com a presença de fragmentos de cerrado, ocorrem em 15,9\%. O cultivo de cana-de-açúcar ocupa cerca de 7,7\% da microbacia e está localizado em grande parte na região sul. Com menor representatividade, ainda ocorrem áreas com cultivo de seringueira e de milho, além de culturas isoladas de menor relevância.

De acordo com a classificação de Köppen, o clima predominante na microbacia é o tropical com verão chuvoso e inverno seco (Aw). A pluviosidade média anual é de $1.344 \mathrm{~mm}$, com maior incidência das chuvas no período de outubro a março e menor de abril a setembro, enquanto a temperatura média anual situa-se na faixa dos $22^{\circ} \mathrm{C}$ (PRADO; JORGE; MENK, 1999).

\section{Bacia B2: Ribeirão do Feijão}

A bacia do Ribeirão do Feijão está localizada na região central do Estado de São Paulo e pertence à UGRHI 13 - Tietê/Jacaré, situando-se no alto curso do Rio Jacaré-Guaçu. Com aproximadamente $242 \mathrm{~km}^{2}$ de extensão tal bacia abrange parte dos municípios de São Carlos, Analândia e Itirapina, e tem como curso d'água principal o Ribeirão do Feijão, o qual possui aproximadamente $23,7 \mathrm{~km}$ de comprimento desde sua nascente principal até seu deságue no 
Rio Jacaré-Guaçu. O Ribeirão do Feijão é utilizado como manancial de captação desde a década de 70, tendo grande importância no abastecimento de água de São Carlos, além de ter importância regional por estar situado em área considerada como de recarga direta do Aquífero Guarani.

A bacia apresenta uma elevação média de $814 \mathrm{~m}$ e amplitude altimétrica de $375 \mathrm{~m}$, com cotas variando entre 650 e 1025 m (Figura 5). Em relação à declividade, mais de 40\% da área da apresenta declives na faixa de "3 a 8\%", caracterizando o relevo como suaveondulado segundo a classificação utilizada pela EMBRAPA (1979). Outras classes de declividade de ocorrência significativa é a de valores entre "0 a 3\%" (relevo plano), em 26,1\% da bacia, e "8 a 20\%" (relevo ondulado), em 19,5\%. A declividade média da área é de 7,9\%.

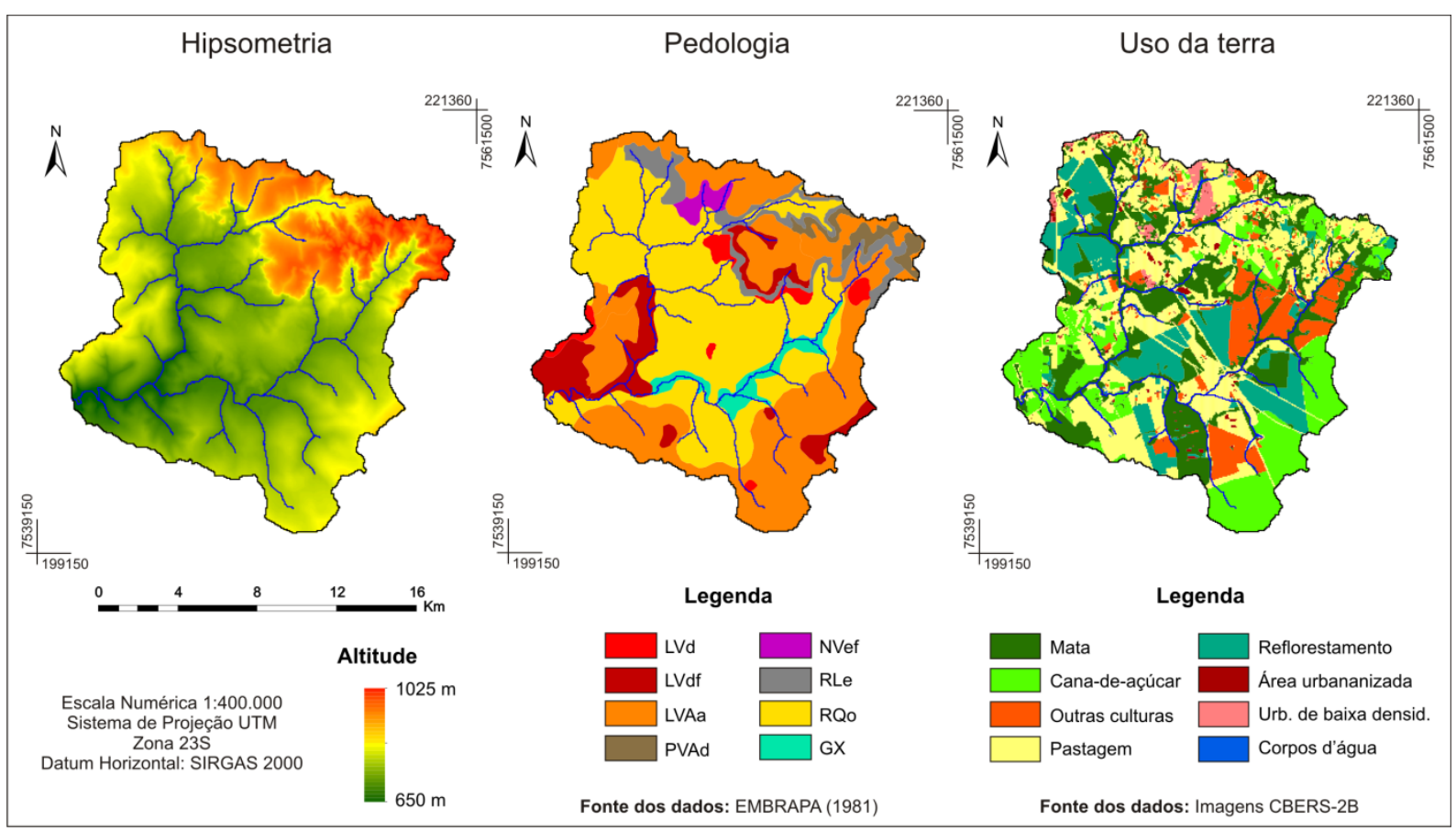

Figura 5 - Caracterização física da bacia do Ribeirão do Feijão.

A região situa-se na província geomorfológica das Cuestas Basálticas, que se caracteriza por apresentar um relevo escarpado nos limites com a Depressão Periférica (ALMEIDA, 1964). O sistema de relevo predominante é o de Colinas Amplas, onde prevalecem interflúvios com área superior a $4 \mathrm{~km}^{2}$, topos extensos e aplainados e vertentes com perfis retilíneos a convexos. A drenagem é de baixa densidade e apresenta padrão subdendrítico, enquanto os vales são abertos com presença de planícies aluviais interiores restritas. Na porção nordeste da bacia ocorre o sistema de Morros Arredondados, constituídos de topos arredondados e localmente achatados e vertentes com perfis convexos a retilíneos, 
localmente ravinados. A drenagem nestes locais é de média densidade, apresentando padrão dendrítico a subdendrítico e os vales são fechados (IPT, 1981).

Em relação à geologia da bacia, segundo Perrotta et al. (2005), afloram na área as unidades litoestratigráficas da Formação Serra Geral, constituída predominantemente por derrames de basaltos toleíticos, e da Formação Botucatu, formada por arenitos eólicos avermelhados de granulação fina a média. Entretanto, a unidade de maior ocorrência corresponde às faixas de depósitos colúvio-eluvionares, caracterizados por deposições recentes, de origem quaternária, constituídos por materiais detríticos localmente remobilizados, em geral compostos por areia, silte e argila.

Segundo o levantamento pedológico semi-detalhado realizado por Oliveira e Prado (1984), exposto na Figura 5, os Neossolos Quartzarênicos órticos (RQo) são os solos predominantes na bacia, ocorrendo em $40,1 \%$ da área. Os Latossolos Vermelho-Amarelos alumínicos (LVAa) perfazem 35,9\%, ocupando locais situados nas maiores altitudes. Em menor escala, ocorrem ainda manchas de Latossolos Vermelhos distroférricos (LVdf) em 8,6\% da bacia, Neossolos Litólicos eutróficos (RLe) nos terrenos de elevada declividade, correspondendo a 6\%, e Gleissolos Háplicos (GX) nas áreas alagadas do Ribeirão do Feijão, totalizando $3,2 \%$, além de outros tipos de solo de menor representatividade.

O uso da terra é voltado primordialmente para atividade agrícola e pecuária, havendo também locais de ocorrência de silvicultura. As áreas de pastagem correspondem a 29,7\% da extensão da bacia, seguidas pelas áreas florestadas, com $26,1 \%$, plantio de cana de açúcar, com 17,4\%, plantações de eucalipto em $13,6 \%$ e culturas agrícolas diversas em $10 \%$, dentre outros usos de menor ocorrência.

O clima da área de estudo é, segundo a classificação climática de Köppen, do tipo Cwa, ou seja, mesotérmico com inverno seco. A precipitação média anual é de $1.515 \mathrm{~mm}$, com mais de $78 \%$ das chuvas ocorrendo na estação chuvosa (outubro a março) e os $22 \%$ restantes no período seco (abril a setembro). Em relação à temperatura, a média anual é de $21,6^{\circ} \mathrm{C}$, onde o mês mais quente é fevereiro, com média mensal de $24,0^{\circ} \mathrm{C}$, e o mês mais frio é junho, com $17,6^{\circ} \mathrm{C}$ (ARROIO JUNIOR, 2013).

\section{Bacia B3: Ribeirão Mandaguari}

Localizada no oeste paulista, tendo parte de seu território em Presidente Prudente e quatro outros municípios, a bacia do Ribeirão Mandaguari possui $740 \mathrm{~km}^{2}$ de extensão. $\mathrm{O}$ Ribeirão Mandaguari tem suas nascentes localizadas na área urbana de Presidente Prudente, 
percorrendo um percurso de $49 \mathrm{~km}$ de comprimento até seu deságue no Rio do Peixe, inserindo-se, portanto, na UGRHI 21 - Peixe.

A elevação média da bacia é de $464 \mathrm{~m}$ e apresenta altitudes entre 300 e $480 \mathrm{~m}$, havendo portanto uma amplitude altimétrica de $180 \mathrm{~m}$ (Figura 6). A declividade média da área é de $6,1 \%$, onde cerca de $43 \%$ da bacia apresenta declives situados na faixa entre " 0 e 3\%", permitindo a classificação do relevo como plano, enquanto 32\% do território apresenta declives entre "8 e 20\%", sendo classificado como ondulado.

Geomorfologicamente, a bacia do Mandaguari localiza-se na província do Planalto Ocidental Paulista (ALMEIDA, 1964). O sistema de relevo dominante em mais de $60 \%$ da área é o de Morrotes Alongados e Espigões, onde predominam interflúvios sem orientação preferencial, topos angulosos a achatados e vertentes com perfis retilíneos e ravinadas. A drenagem possui média a alta densidade, com padrão dendrítico, e os vales são fechados (IPT, 1981). Ocorrem ainda áreas com relevos de Colinas Amplas e Colinas Médias, cujas descrições foram apresentadas nas seções anteriores.

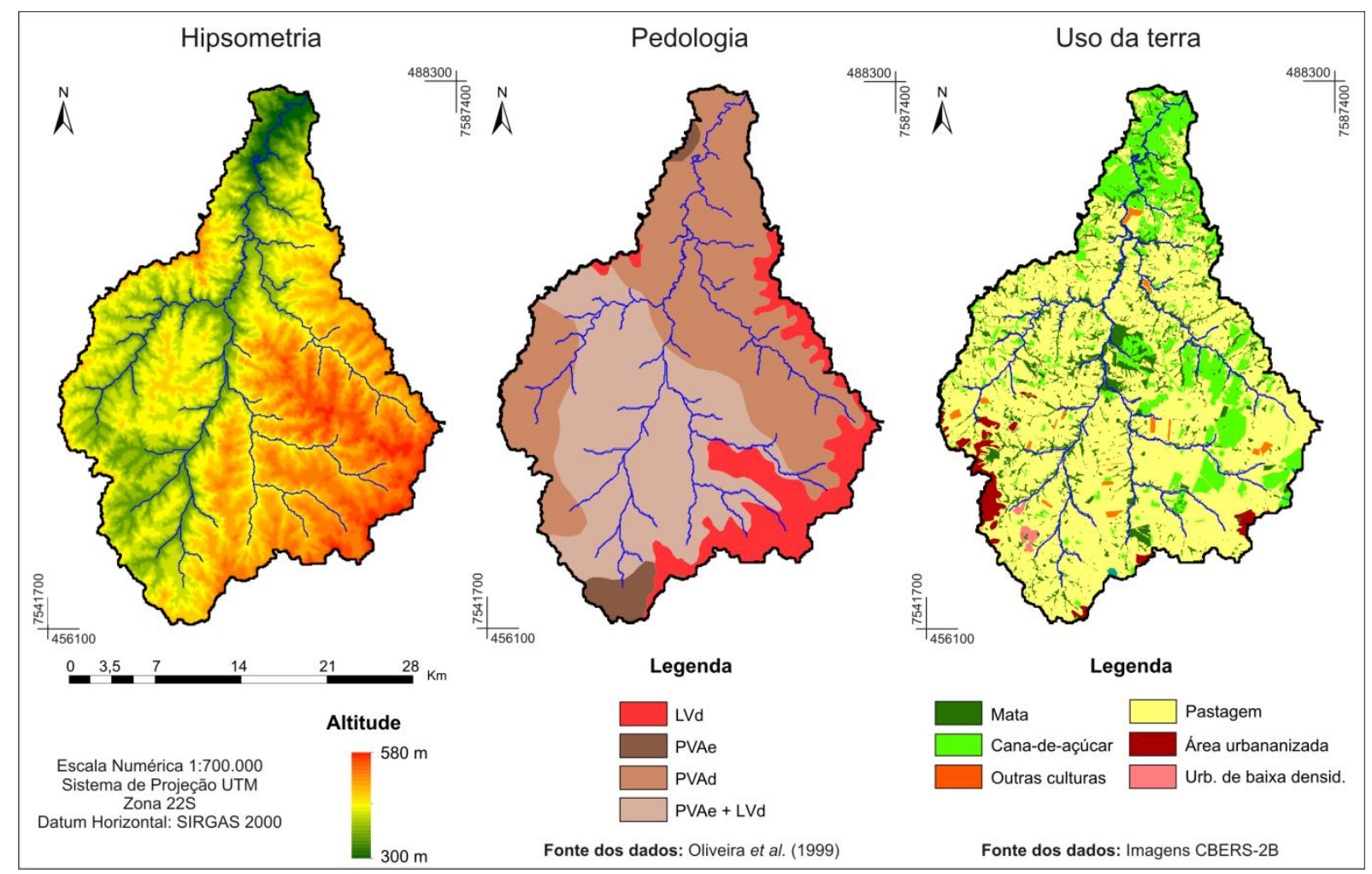

Figura 6 - Caracterização física da bacia do Ribeirão Mandaguari.

Com relação à geologia, ocorrem na bacia formações do Grupo Bauru, de origem cretácea, compostas basicamente de arenitos. A unidade predominante é a Formação 
Presidente Prudente, composta principalmente de arenitos muito finos a finos, de cores marrom avermelhada a bege, moderadamente a mal selecionados, com matriz pelítica e cimentados por calcita, além de lamitos argilosos de cor marrom escuro (PERROTTA et al., 2005). Além disso, ocorrem também extensas áreas da Formação Vale do Rio do Peixe, cuja síntese já foi apresentada na descrição da Bacia B1 - Córrego Cana-do-Reino.

Os solos presentes na bacia, segundo levantamento realizado por Oliveira et al. (1999), compõem-se majoritariamente de Argissolos Vermelho-Amarelos, ocorrendo os subtipos Argissolos Vermelho-Amarelos distróficos (PVAd), em 44,5\% da área, e associação entre Argissolos Vermelho-Amarelos eutróficos e Latossolos Vermelhos distróficos (PVAe + LVd), em 38,5\% da bacia. Ocorrem ainda, nas áreas de maior elevação, faixas de Latossolos Vermelhos distróficos ( $\mathrm{LVd}$ ), em 13,9\%, e uma mancha de Argissolo Vermelho-Amarelo eutrófico (PVAe), perfazendo 2,9\%.

O uso da terra de maior recobrimento na bacia são as pastagens, ocorrendo em $70 \%$ da área. Voltados para pecuária bovina, tais espaços apresentam diversos padrões de crescimento, indicando rodízio no uso. Ao norte, já próximo ao deságue no Rio do Peixe, desenvolvem-se áreas de cultivo de cana-de açúcar, perfazendo 14\% do território. Os espaços de mata densa são escassos e fragmentados, ocorrendo principalmente na forma de Áreas de Preservação Permanente, em 11,5\% da bacia, enquanto áreas com urbanização respondem por $2,2 \%$ de seu total.

Segundo a classificação climática de Köppen, ocorre na bacia o clima Aw, tropical com verão chuvoso e inverno seco, caracterizado por temperaturas médias anuais ligeiramente inferiores a $23^{\circ} \mathrm{C}$, com chuvas típicas de clima tropical de maior ocorrência no verão. A precipitação e a temperatura média anual são de $1.277 \mathrm{~mm}$ e de $22,8^{\circ} \mathrm{C}$, respectivamente.

\section{Bacia B4: Rio do Pari}

A bacia do Rio do Pari possui uma área total de $1024 \mathrm{~km}^{2}$ e situa-se na região do município de Assis, no oeste do estado de São Paulo, integrando a UGRHI 17 - Médio Paranapanema. O Rio do Pari tem suas nascentes no município de Echaporã, percorrendo um trajeto de $62 \mathrm{~km}$ de comprimento até desaguar no Rio Paranapanema pela margem direita, entre os municípios de Palmital e Cândido Mota. Nesse percurso, encontra-se a barragem da PCH Pari-Veado, que conta com uma potência instalada de 1,3MW e um reservatório de 1,8 $\mathrm{km}^{2}$. A bacia apresenta ainda importância ecológica, visto que nela situa-se a Estação 
Ecológica de Assis, a qual abriga fisionomias de cerrado e tem a função de proteger o manancial de abastecimento público da cidade de Assis.

A bacia apresenta uma altitude média de $509 \mathrm{~m}$, com cotas altimétricas variando entre 345 e $705 \mathrm{~m}$, totalizando um desnível altimétrico de $360 \mathrm{~m}$, conforme pode ser observado na Figura 7. Mais de $52 \%$ dos terrenos da bacia situam-se na faixa de declives entre "3 e 8\%", classificando o relevo em suave-ondulado (EMBRAPA, 1979), enquanto 24\% do território apresenta declividades ente "8 e $20 \%$ ", relevo considerado como ondulado. A declividade média da bacia é de $6,1 \%$.

Em relação à geomorfologia, a área localiza-se na grande província geomorfológica do Planalto Ocidental Paulista (ALMEIDA, 1964). O sistema de relevo de Colinas Amplas, já descrito anteriormente, ocorre em toda a extensão da bacia (IPT, 1981).

Já com relação à geologia, ocorrem na área unidades litoestratigráficas datadas do período Cretáceo, notadamente os basaltos da Formação Serra Geral, do Grupo São Bento, e os arenitos da Formação Vale do Rio do Peixe, do Grupo Bauru (PERROTTA et al., 2005), ambos já apresentados na descrição das demais bacias.

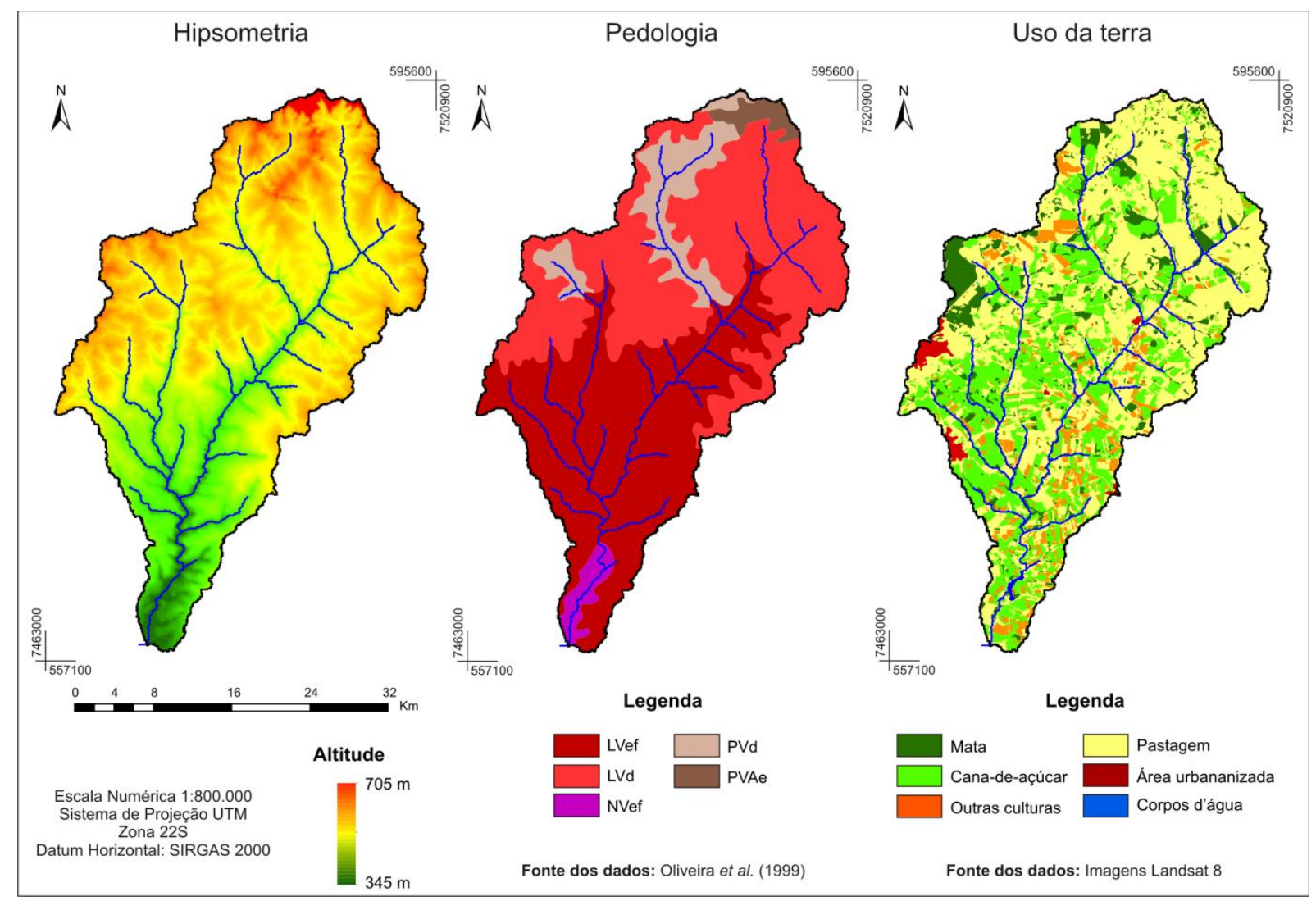

Figura 7 - Caracterização física da bacia do Rio Pari. 
Segundo o levantamento pedológico realizado por Oliveira et al. (1999), o tipo de solo predominante na área são os Latossolos Vermelhos, ocorrendo os subtipos eutroférrico (LVef) em $43 \%$ da área e distrófico ( $\mathrm{LVd}$ ) em $42 \%$ do território (Figura 7). Afloram também nas partes mais altas faixas de Argissolos Vermelho-Amarelos eutróficos (PVAe) e Argissolos Vermelhos distróficos (PVd), perfazendo aproximadamente 9,6\% e 1,8\%, respectivamente. Próximo à foz no Rio Paranapanema, ocorre uma faixa de Nitossolo Vermelho eutroférrico (NVef), a qual corresponde a 2,2\% da área.

O uso da terra predominante na bacia são as pastagens, ocorrendo em $51 \%$ da área, seguido do cultivo de cana-de-açúcar, presente em $29 \%$. Com um total de 10\%, as áreas de mata densa ocorrem principalmente a oeste, nos limites da Estação Ecológica de Assis, e, de forma mais esparsa, sob a forma de Reserva Legal em propriedades rurais. Outros usos agrícolas respondem por aproximadamente $7 \%$ da bacia, enquanto as áreas com urbanização possuem $1,2 \%$ de participação.

Segundo a classificação climática de Köppen, a bacia do Rio Pari está compreendida no clima Am, tropical úmido, onde ocorrem chuvas excessivas e inverno seco (ROLIM et al., 2007) . Nesse tipo de clima, as temperaturas são superiores a $22^{\circ} \mathrm{C}$ no verão e ocorrem mais de $30 \mathrm{~mm}$ de chuva no mês mais seco. A precipitação média anual situa-se em torno de 1.470 mm, e a temperatura média anual é de $22^{\circ} \mathrm{C}$.

\section{Bacia B5: Alto Rio Paranapanema}

A bacia aqui denominada como Alto Rio Paranapanema compreende a parte superior da UGRHI 14 - Alto Paranapanema, abrangendo o trecho que vai desde as nascentes do referido rio, situadas no município de Capão Bonito, até sua confluência com o Rio ApiaíGuaçu, à montante do Reservatório de Jurumirim. Neste percurso, o rio percorre um trecho de aproximadamente $131 \mathrm{~km}$, no qual vai recebendo contribuições dos Rios Turvo, das Almas, Paranapitanga e Itapetininga. Tal compartimento possui uma área aproximada de $5.959 \mathrm{~km}^{2}$, com territórios em 11 municípios sitiados na microrregião de Itapetininga.

A bacia apresenta valores de altitude situados entre 560 e $1.130 \mathrm{~m}$, totalizando um desnível altimétrico de $570 \mathrm{~m}$, além de altitude média de $714 \mathrm{~m}$. Em relação à declividade, esta apresenta em $46 \%$ da sua área declives situados na faixa de "8 a 20\%", o que classifica o relevo em ondulado, conforme definição da EMBRAPA (1979). Em relação às outras classes de declividade, $26 \%$ da bacia apresentam relevo suave-ondulado (declives de "3 a $8 \%$ ") e $17 \%$ forte-ondulado (declives de "20 a 45\%"). 


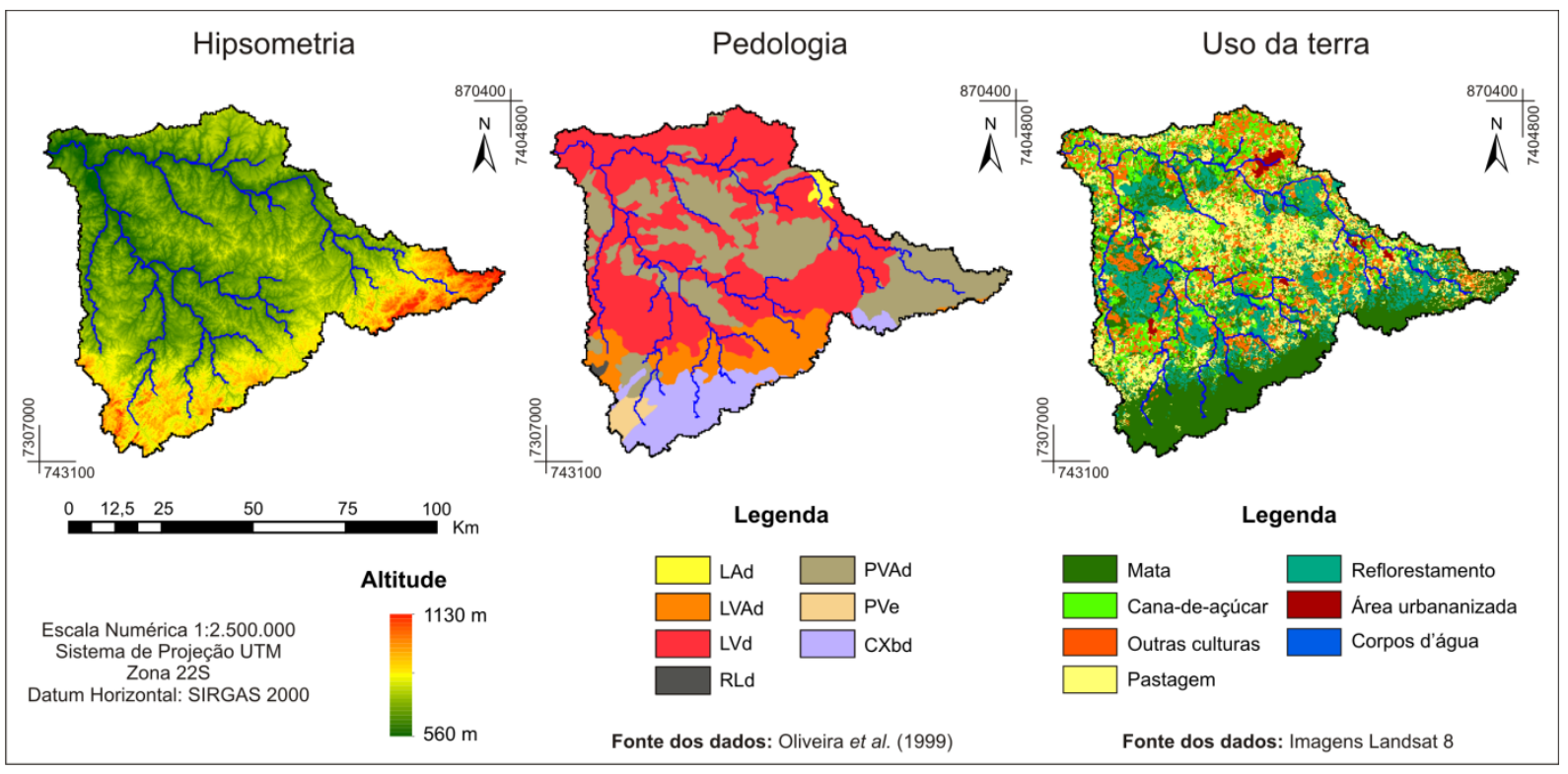

Figura 8 - Caracterização física da bacia do alto Rio Paranapanema.

Em relação à geomorfologia, o Alto Paranapanema situa-se nos limites da província geomorfológica da Depressão Periférica, tendo parte da bacia na província do Planalto Atlântico (ALMEIDA, 1964). Desse modo, ocorrem associados à Depressão Periférica os sistemas de relevo de Colinas Amplas, na maior parte da bacia, de Morrotes Alongados e Espigões, de Colinas Médias e algumas Planícies Aluviais. Já estando associados à Província do Planalto Atlântico, ocorrem os sistemas de Morros Paralelos e Mares de Morros (IPT, 1981).

Com relação à geologia, ocorrem em mais de 50\% da área rochas do Grupo Itararé, do período Permiano, como arenitos, diamictitos, tilitos, siltitos, folhelhos, ritmitos, varvitos, conglomerados e raras camadas de carvão. Ao norte, afloram extensas faixas de argilitos e siltitos das formações Tatuí, Teresina e Irati, também do período Permiano. Já na porção sul e sudeste, nas áreas de maior altitude da bacia, afloram rochas mais antigas, datadas do período Calimiano (Era Mesoproterozóica), a exemplo das unidades terrígena e metavulcanossedimentar, ambas pertencentes ao Grupo Votuverava. Verifica-se também nessas áreas, porém em menor escala, formações graníticas de origem neoproterozóicas (PERROTTA et al., 2005).

Com relação aos solos, segundo o levantamento pedológico de Oliveira et al. (1999), ocorre a predominância de Latossolos Vermelhos distróficos (LVd) em 48,4\% da área, seguido de faixas de Argissolos Vermelhos-Amarelos distróficos (PVAd), em 29,3\%, e Latossolos Vermelhos-Amarelos distróficos (LVAd), em 10,1\%. Nas áreas de relevo 
escarpado ao sul, afloram Cambissolos Háplicos Tb distróficos (CXbd), totalizando 9,5\% da área. Em menor escala, ocorrem ainda Neossolos Litólicos distróficos (RLd), Latossolos Amarelos distróficos (LAd) e Argissolos Vermelhos eutróficos (PVe).

Em relação ao uso da terra, a bacia apresenta grandes extensões de áreas vegetadas, englobando tipos fisionômicos como mata, capoeira, campo, cerradão e cerrado, totalizando $32 \%$ de sua área (CBH-ALPA, 2013). Tais coberturas distribuem-se principalmente nos terrenos de maior elevação ao sul da bacia e em quatro Unidades de Conservação localizadas em seu interior. Outro uso de significância são os reflorestamentos dos tipos Pinus e Eucaliptos, perfazendo $18 \%$ da bacia. Áreas de pastagem e culturas agrícolas diversas, como citrus, café, seringueira e outras frutíferas, ocorrem em $21 \%$ e $15 \%$ da área, respectivamente. Já o plantio de cana-de-açúcar é encontrado em $13 \%$ da bacia.

Segundo a classificação climática de Köppen, a bacia do alto Rio Paranapanema está compreendida no clima temperado úmido, com verão quente (Cfa) (ROLIM et al., 2007). Nesse tipo de clima, as temperaturas são superiores a $22^{\circ} \mathrm{C}$ no verão e ocorrem mais de 30 mm de chuva no mês mais seco. A pluviosidade média anual situa-se em torno de $1446 \mathrm{~mm}$ e a temperatura média anual é de $21,9^{\circ} \mathrm{C}$.

\subsection{Descrição geral das rotinas de simulação hidrológica do modelo SWAT}

Conforme salientado anteriormente, a principal força motriz das simulações envolvendo o SWAT é o balanço hidrológico, sendo sua correta representação uma etapa fundamental para trabalhos envolvendo simulações de sedimentos, agroquímicos e/ou geração de cenários hipotéticos. Nesta seção será apresentada uma descrição sucinta das rotinas de simulação hidrológica utilizadas pelo modelo conforme apresentadas por Neitsch et al. (2011) no manual teórico do SWAT. Para uma descrição mais detalhada das rotinas e operações aqui apresentadas recomenda-se a consulta ao texto integral dos autores.

Os fenômenos simulados pelo SWAT têm como principal fator controlador a equação geral do balanço hídrico aplicada ao perfil de solo, conforme formalizada a seguir:

$$
S W_{t}=S W_{0}+\sum_{i=1}^{t}\left(R_{\text {day }}-Q_{\text {surf }}-E_{a}-w_{\text {seep }}-Q_{g w}\right)
$$

Onde $S W_{t}$ é o conteúdo final de água no solo $(\mathrm{mm}), S W_{0}$ é o conteúdo inicial de água no solo no dia $i(\mathrm{~mm}), t$ é o tempo (dias), $R_{d a y}$ é a precipitação no dia $i(\mathrm{~mm}), Q_{\text {surf }}$ é o 
escoamento superficial no dia $i(\mathrm{~mm}), E_{a}$ é a evapotranspiração no dia $i(\mathrm{~mm}), w_{\text {seep }}$ é a quantidade de água que percola na zona vadosa $(\mathrm{mm})$ e $Q_{g w}$ é a quantidade de água que retorna ao curso d'água no dia $i$ por escoamento subsuperficial ( $\mathrm{mm})$.

O sistema hidrológico simulado pelo SWAT compreende quatro principais componentes: os reservatórios superficiais, os reservatórios subsuperficiais, os reservatórios subterrâneos (aquíferos rasos ou livres) e os reservatórios subterrâneos (aquífero profundo). A contribuição desses reservatórios para o escoamento no canal provém do fluxo lateral a partir do perfil de solo e do fluxo de retorno do aquífero raso. $\mathrm{O}$ volume que percola do reservatório subsuperficial através do perfil de solo representa a recarga do aquífero raso, enquanto a água que percola para o aquífero profundo não retorna para o sistema.

No processo de modelagem, a evapotranspiração é computada considerando-se os processos de maneira distinta: a evaporação de corpos d'água, do solo e das superfícies com vegetação e o processo de transpiração das plantas. As parcelas evaporativas do solo e da água aderida à superfície das plantas são estimadas separadamente, conforme procedimento descrito por Ritchie (1972). A evaporação da água no solo é estimada através de relações exponenciais entre a profundidade do solo e a quantidade de água disponível. Já a transpiração das plantas é calculada em função da evapotranspiração potencial e do índice de área foliar.

A evapotranspiração potencial representa a taxa em que a evapotranspiração poderia ocorrer em uma grande área uniformemente coberta por vegetação e com fornecimento ilimitado de água no solo. O modelo oferece três meios para estimar a evapotranspiração potencial, sendo eles os métodos de Hargreaves (HARGREAVES et al., 1985), PriestleyTaylor (PRIESTLEY; TAYLOR, 1972) e Penman-Monteith (MONTEITH, 1965).

Quando há ocorrência de precipitações na bacia, uma parcela da água pode ser interceptada e aderida à vegetação e outra parte pode cair diretamente na superfície do solo. Dependendo do grau de saturação do solo, parte da água infiltrará através das camadas do perfil ou se movimentará na encosta na forma de escoamento superficial. O escoamento se movimenta de maneira relativamente rápida na direção do canal contribuindo para uma resposta do curso d'água em curto prazo.

O escoamento superficial ou deflúvio ocorre apenas a partir do instante que o volume de água que alcança o solo excede a sua taxa de infiltração ou a sua capacidade de armazenamento. O modelo pode simular o volume de escoamento superficial e as taxas máximas de escoamento para cada HRU utilizando totais de precipitação tanto diários como subdiários, conforme inserido pelo usuário. 
O volume de escoamento superficial é computado utilizando-se a uma modificação do método da Curva Número proposta pelo Soil Conservation Service (USDA; SCS, 1972) ou o método de infiltração de Green \& Ampt (GREEN; AMPT, 1911). No método da Curva Número, o parâmetro Número da Curva varia não linearmente com o teor de umidade do solo. O valor do Número da Curva decresce conforme o solo se aproxima do ponto de murcha e aumenta conforme se aproxima da saturação. Já para a aplicação do método de Green \& Ampt, é necessária a inserção de dados de precipitação subdiários, visto que o cálculo da infiltração é realizado em função do potencial matricial da frente de umidade e da condutividade hidráulica efetiva.

O cálculo da infiltração, ou seja, da quantidade de água que adentra no perfil de solo, está relacionado ao método escolhido para o cálculo do escoamento superficial. Quando se utiliza o método da Curva Número para o escoamento, a infiltração é calculada apenas como a simples diferença entre a quantidade precipitada e a quantidade de escoamento gerado. Isto ocorre porque o método da Curva Número utiliza dados de precipitação em passo diário, tornando-se impossível a modelagem direta da infiltração. Já quando se utiliza o método de Green \& Ampt a infiltração é modelada diretamente, porém, conforme salientado, sua utilização está condicionada ao uso de dados de precipitação subdiários.

Após infiltrar, a água é redistribuída por todas as camadas do perfil de solo devido às diferenças no gradiente de umidade, até apresentar-se de maneira uniforme em todo o perfil, cessando a redistribuição. No SWAT tal processo é representado através de uma técnica de propagação do armazenamento para prever o fluxo por cada camada de solo. Quando a capacidade de retenção de água de uma camada é ultrapassada a água percola para a camada imediatamente abaixo, processo simulado por um modelo de fluxo por fendas existentes no solo, sendo regido pela condutividade hidráulica saturada das camadas do perfil.

O escoamento subsuperficial, também denominado fluxo lateral, é uma contribuição do fluxo d’água que se origina abaixo da superfície, mas acima da zona saturada. Para o seu cálculo, o SWAT utiliza o modelo de armazenamento cinemático desenvolvido por Sloan et al. (1983), baseado na equação de continuidade de massa, no qual se considera o balanço hídrico utilizando todo o segmento da encosta como volume de controle em um fluxo bidimensional.

As previsões das taxas máximas de escoamento superficial são realizadas a partir do Método Racional Modificado. Tal método é fundamentado na suposição de que, se uma chuva de intensidade $i$ inicia instantaneamente e continua indefinidamente, a taxa de escoamento vai 
aumentar até que se atinja o tempo de concentração da bacia, quando toda a sua área estará contribuindo para o fluxo na saída. A equação do Método Racional Modificado é dada por:

$$
q_{\text {peak }}=\frac{\alpha_{t c} \cdot Q_{\text {surf }} \cdot A}{3,6 \cdot t_{\text {conc }}}
$$

Onde $q_{p e a k}$ é a vazão de pico $\left(\mathrm{m}^{3} \cdot \mathrm{s}^{-1}\right), \alpha_{t c}$ é a fração da precipitação diária que ocorre durante o tempo de concentração, $Q_{\text {surf }}$ é o volume de escoamento superficial (mm.ha ${ }^{-1}$ ), $A$ é a área da sub-bacia $\left(\mathrm{km}^{2}\right)$ e $t_{\text {conc }}$ é o tempo de concentração da sub-bacia (h). A fração da precipitação diária que ocorre na sub-bacia durante o tempo de concentração é estimada como uma função do total diário de precipitação, por meio de técnicas estocásticas. O tempo de concentração da sub-bacia é calculado usando a fórmula de Manning, considerando-se tanto o fluxo por via terrestre quanto o fluxo no canal.

Por fim, uma vez que o SWAT determina o acúmulo de água para o canal principal proveniente de cada sub-bacia, os montantes são propagados através da rede de drenagem da bacia hidrográfica até o seu exutório. Tal processo pode-se basear em duas estruturas de comando disponíveis para serem escolhidas pelo usuário, sendo ambas variações do Modelo de Onda Cinemática (CHOW et al., 1988): o Método da Média Variável (WILLIAMS, 1969) e o Método de Muskingum (OVERTON, 1966).

Nas seções seguintes será apresentado um maior detalhamento das rotinas de cálculo do SWAT relacionadas à determinação da evapotranspiração, visto a maior importância deste processo no contexto deste trabalho.

\subsubsection{Evapotranspiração potencial pelo método de Penman-Monteith}

Conforme salientado, o SWAT disponibiliza três métodos distintos para o cálculo da evapotranspiração potencial: os métodos de Hargreaves (HARGREAVES et al., 1985), de Priestley-Taylor (PRIESTLEY; TAYLOR, 1972) e de Penman-Monteith (MONTEITH, 1965). Neste trabalho, será adotado o método de Penman-Monteith, considerado como método padrão para o cálculo da evapotranspiração potencial pela FAO.

A equação de Penman-Monteith combina componentes que avaliam a energia necessária para a ocorrência de evaporação, os mecanismos necessários para remover o vapor de água contido nos vegetais para a atmosfera, um termo relativo à resistência aerodinâmica e 
outro termo referente à resistência foliar à difusão de vapor. A equação de Penman-Monteith utilizada pelo modelo SWAT é dada por:

$$
\lambda E_{t}=\frac{\Delta \cdot\left(H_{n e t}-G\right)+\gamma \cdot K_{1} \cdot\left(0,622 \cdot \lambda \cdot \frac{\rho_{a i r}}{P}\right) \cdot \frac{\left(e_{z}^{o}-e_{z}\right)}{r_{a}}}{\Delta+\gamma \cdot\left(1+\frac{r_{c}}{r_{a}}\right)}
$$

Em que $\lambda$ é o calor latente de vaporização $\left(\mathrm{MJ} \mathrm{kg}^{-1}\right), E_{t}$ é a taxa de transpiração máxima $\left(\mathrm{mm}^{-1} \mathrm{~d}^{-1}\right), \Delta$ é o ângulo da curva de pressão de vapor de saturação $\left(\mathrm{kPa} .{ }^{\circ} \mathrm{C}^{-1}\right), H_{n e t}$ é a radiação líquida diária $\left(\mathrm{MJ} \cdot \mathrm{m}^{-2} \cdot \mathrm{d}^{-1}\right), G$ é a densidade do fluxo de calor para o solo $\left(\mathrm{MJ} \cdot \mathrm{m}^{-2} \cdot \mathrm{d}^{-}\right.$ $\left.{ }^{1}\right), \gamma$ é a constante psicrométrica $\left(\mathrm{kPa} .{ }^{\circ} \mathrm{C}^{-1}\right), \rho_{\text {air }}$ é a densidade do $\operatorname{ar}\left(\mathrm{kg} \cdot \mathrm{m}^{-3}\right), P$ é a pressão atmosférica $(\mathrm{kPa}), e_{z}^{o}$ é a pressão de vapor de saturação de ar na altura $z(\mathrm{kPa}), e_{z}$ é a pressão de vapor na altura $z(\mathrm{kPa}), r_{a}$ é a resistência aerodinâmica $\left(\mathrm{s} . \mathrm{m}^{-1}\right)$ e, por fim, $r_{c}$ é a resistência do dossel $\left(\mathrm{s} . \mathrm{m}^{-1}\right)$. Na equação 4.3 , o termo $K_{l}$ é um coeficiente necessário para assegurar que os dois termos no numerador tenham as mesmas unidades $\left(K_{l}=8,64 \times 10^{4}\right)$.

As formulações utilizadas pelo SWAT para obtenção de cada um dos termos da equação é apresentada nos itens seguintes.

\section{Balanço de radiação solar}

A radiação solar exerce um importante controle na movimentação da água na fase terrestre do ciclo hidrológico, influenciando fortemente o processo de evapotranspiração. No cálculo da radiação líquida diária, $H_{n e t}$, é necessária a determinação de parâmetros básicos relacionados à posição da Terra em relação ao Sol, como o fator de correção de excentricidade da Terra, a declinação solar e a hora do nascer do sol.

A astronomia considera a distância média entre a Terra e o Sol como sendo de aproximadamente $1,49 \times 10^{8} \mathrm{~km}$, sendo tal valor adotado como uma unidade de distância denominada de unidade astronômica (UA). A Terra gira em torno do Sol em uma órbita elíptica onde a distância entre os dois corpos em qualquer dia do ano irá variar de um máximo de 1,017 UA a um mínimo de 0,983 UA. O alcance da radiação solar na superfície da Terra é inversamente proporcional ao quadrado de sua distância do Sol, sendo tal propriedade exprimida através do fator de correção da excentricidade da órbita da Terra $\left(E_{0}\right)$. Para a 
maioria das aplicações de engenharia a simplificação proposta por Duffie (1980) é adequada para calcular tal fator, sendo dada por:

$$
E_{0}=\left(\frac{r_{0}}{r}\right)^{2}=1+0,033 \cos \left(\frac{2 \pi d_{n}}{365}\right)
$$

Em que $r_{0}$ é a distância média entre a Terra e o Sol (1 UA), $r$ é a distância Terra-Sol para um determinado dia do ano (UA) e $d_{n}$ é o dia juliano ou dia do ano, o qual varia sequencialmente de 1 (em $1^{\circ}$ de Janeiro) até 365 (em 31 de Dezembro). Considera-se que o mês de Fevereiro tem sempre 28 dias, fazendo com que a precisão da equação varie devido ao ciclo do ano bissexto.

A declinação solar consiste no ângulo formado entre os raios da luz solar e o plano do equador. A declinação varia anualmente conforme o movimento de translação, sendo nula quando o Sol se encontra exatamente sobre a linha do Equador (equinócios), aproximadamente $+23^{\circ} 27^{\prime}$ no solstício de verão no hemisfério norte (solstício de inverno no hemisfério sul) e aproximadamente $-23^{\circ} 27^{\prime}$ no solstício de inverno no hemisfério norte (e de verão no hemisfério sul). O cálculo da declinação solar é realizado por meio da equação de Perrin de Brichambaut (1975):

$$
\delta=\sin ^{-1}\left\{0,4 \sin \left[\frac{2 \pi}{365}\left(d_{n}-82\right)\right]\right\}
$$

Onde $\delta$ é a declinação solar em radianos e $d_{n}$ é o dia juliano correspondente ao número de dias transcorridos desde o dia $1^{\circ}$ de janeiro.

A determinação da hora do nascer do sol $\left(T_{S R}\right)$ é realizada por meio da equação:

$$
T_{S R}=+\frac{\cos ^{-1}(-\tan \delta \tan \phi)}{\omega}
$$

Em que $\delta$ é a declinação solar (rad), cujo cálculo foi apresentado anteriormente, $\phi$ é a latitude (em radianos) e $\omega$ é a velocidade angular de rotação da Terra (adota-se o valor de $\left.0,2618 \mathrm{rad} \cdot \mathrm{h}^{-1}\right)$.

Quando a radiação solar entra na atmosfera da Terra, uma parcela da energia é atenuada devido aos processos de dispersão e absorção. A quantidade de energia perdida 
depende de fatores como a transmitância da atmosfera, a composição e concentração dos constituintes do ar no local, o percurso que a radiação viaja através da coluna de ar e o comprimento de onda da radiação. Devido à complexidade das variáveis envolvidas nestes processos, o SWAT opera supondo que a perda de energia radiante extraterrestre durante a passagem pela atmosfera é da ordem de $20 \%$. Usando essa suposição, a radiação solar máxima possível, $H_{M X}$, em um determinado local é calculada como:

$$
H_{M X}=30,0 E_{0}\left[\omega T_{S R} \sin \delta \sin \phi+\cos \delta \cos \phi \sin \left(\omega T_{S R}\right)\right]
$$

Onde $H_{M X}$ é a radiação solar máxima possível em um determinado dia de céu limpo $\left(\mathrm{MJ}_{\mathrm{m}} \mathrm{m}^{-2} \cdot \mathrm{d}^{-1}\right), E_{0}$ é o fator de correção de excentricidade da órbita da Terra, $\omega$ é a velocidade angular da rotação da Terra $\left(\right.$ rad. $\left.^{-1}\right), T_{S R}$ é a hora do nascer do sol (h), $\delta$ é a declinação solar (rad) e $\phi$ é a latitude (rad).

Para obtenção da radiação líquida diária é necessária a determinação das parcelas de radiação líquida de onda curta e radiação líquida de onda longa. A radiação líquida de onda curta, ou seja, a quantidade de radiação solar que chega à superfície terrestre e fica disponível para os processos de aquecimento e evaporação da água, é obtida através da equação:

$$
H_{S}=H_{d a y} \cdot(1-\alpha)
$$

Em que é $H_{d a y}$ é a radiação solar de onda curta que atinge o solo em determinado dia $\left(\mathrm{MJ}_{\mathrm{m}} \mathrm{m}^{-2} \cdot \mathrm{d}^{-1}\right)$ e $\alpha$ é a refletância ou o albedo de onda curta. Nas simulações, o SWAT calcula um valor diário para o albedo em função do tipo de solo e da cobertura vegetal. Quando há crescimento vegetal em determinada HRU, o albedo é calculado por:

$$
\alpha=\alpha_{\text {plant }} \cdot\left(1-\operatorname{cov}_{\text {sol }}\right)+\alpha_{\text {sol }} \cdot \operatorname{cov} v_{\text {sol }}
$$

Onde $\alpha_{p l a n t}$ é o albedo para uma cultura hipotética (fixado em 0,23), $\alpha_{\text {sol }}$ é o albedo para o tipo de solo e $c o v_{s o l}$ é o índice de cobertura do solo. O índice de cobertura do solo é calculado por:

$$
\operatorname{cov}_{\text {sol }}=\exp \left(-5,0 \times 10^{-5} \cdot C V\right)
$$


Em que $C V$ é a biomassa e o resíduo acima do solo $\left(\mathrm{kg} \cdot \mathrm{ha}^{-1}\right)$.

O balanço de radiação de onda longa, ou seja, da radiação emitida pela superfície terrestre, é fundamentado com base na lei de emissão eletromagnética de Stefan-Boltzmann. A equação padrão para o cálculo da radiação líquida de onda longa no modelo SWAT utiliza uma forma modificada da Lei de Stefan-Boltzmann, proposta por Jensen, Burman e Allen (1990) e atualizada com valores de coeficientes propostos por Doorenbos e Pruitt (1977):

$$
H_{b}=-\left[0,9 \cdot \frac{H_{d a y}}{H_{M X}}+0,1\right] \cdot[0,34-0,139 \sqrt{e}] \cdot \sigma \cdot T_{K}{ }^{4}
$$

Na equação apresentada, $H_{b}$ é a radiação líquida de onda longa $\left(\mathrm{MJ}^{\mathrm{m}} \mathrm{m}^{-2} \cdot \mathrm{d}^{-1}\right), H_{\text {day }}$ é a radiação solar medida em determinado dia $\left(\mathrm{MJ} . \mathrm{m}^{-2} \cdot \mathrm{d}^{-1}\right), H_{M X}$ é a radiação solar máxima possível em um determinado dia $\left(\mathrm{MJ} \cdot \mathrm{m}^{-2} \cdot \mathrm{d}^{-1}\right)$, e é a pressão de vapor $(\mathrm{kPa})$, cujo cálculo é apresentado na próxima seção, $\sigma$ é a Constante de Stefan-Boltzmann (4,903 x $10^{-9} \mathrm{MJ} \cdot \mathrm{m}^{-2} \cdot \mathrm{K}^{-}$ $\left.{ }^{4} \cdot \mathrm{d}^{-1}\right)$ e $T_{K}$ é a temperatura média do ar em Kelvin $\left(273,15+{ }^{\circ} \mathrm{C}\right)$.

Dessa forma, a partir do balanço de radiação de onda curta e onda longa, calcula-se a radiação líquida diária, $H_{\text {net }}$ :

$$
H_{n e t}=(1-\alpha) \cdot H_{d a y}+H_{b}=H_{s}+H_{b}
$$

Com base nos cálculos apresentados nesta seção, verifica-se que as únicas variáveis de entrada do modelo SWAT diretamente relacionadas ao cálculo da radiação líquida diária são a radiação solar diária, obtida nas estações meteorológicas, e o albedo do solo.

\section{Parâmetros relacionados ao vapor d'água na atmosfera}

Parâmetros relacionados ao vapor d'água na atmosfera, como a pressão de vapor $(e)$ e a constante psicrométrica $(\gamma)$, são necessários na equação de Penman-Monteith. Tais parâmetros são calculados com base nos dados de umidade relativa do ar inseridos pelo usuário.

A umidade relativa é a razão entre a pressão de vapor real de um volume de ar e sua pressão de vapor de saturação, conforme a equação: 


$$
R H=\frac{e}{e^{o}}
$$

Onde $R H$ é a umidade relativa em determinado dia, $e$ é a pressão de vapor real $(\mathrm{kPa})$, e $e^{o}$ é a pressão de vapor de saturação $(\mathrm{kPa})$.

A pressão de vapor de saturação é a pressão de vapor máxima que é estável termodinamicamente e é uma função da temperatura do ar. O modelo SWAT calcula a pressão de vapor de saturação usando a equação de Tetens (1930) e Murray (1967):

$$
e^{o}=\exp \left(\frac{16,78 \cdot T_{a v}-116,9}{T_{a v}+237,3}\right)
$$

Em que em que $e^{o}$ é a pressão de vapor de saturação em um determinado dia $(\mathrm{kPa})$ e $T_{a v}$ é a média da temperatura diária do ar $\left({ }^{\circ} \mathrm{C}\right)$. Quando a umidade relativa é conhecida, a pressão de vapor real pode ser calculada reorganizando-se a equação 4.13:

$$
e=R H \cdot e^{o}
$$

A curva de pressão de vapor de saturação é obtida através da representação gráfica da equação 4.14. Desse modo, o ângulo da curva de pressão de vapor de saturação, $\Delta$, pode ser calculado através da diferenciação desta mesma equação, o que resulta em:

$$
\Delta=\frac{4098 \cdot e^{o}}{\left(T_{a v}+237,3\right)^{2}}
$$

Em que $\Delta$ é o ângulo da curva de pressão de vapor de saturação $\left(\mathrm{kPa} .{ }^{\circ} \mathrm{C}^{-1}\right), e^{o}$ é a pressão de vapor de saturação em um determinado dia $(\mathrm{kPa})$ e $T_{a v}$ é a temperatura média diária do ar $\left({ }^{\circ} \mathrm{C}\right)$.

A taxa de evaporação é proporcional à diferença entre a pressão de vapor da camada superficial e a pressão de vapor do ar sobrejacente. Essa diferença é chamada de déficit de pressão de vapor, $v p d$.

$$
v p d=e^{o}-e
$$


Em que $v p d$ é o déficit de pressão de vapor $(\mathrm{kPa}), e^{o}$ é a pressão de vapor de saturação $(\mathrm{kPa})$, e $e$ é a pressão de vapor real $(\mathrm{kPa})$. Quanto maior o valor de $v p d$, maior será a taxa de evaporação.

O calor latente de vaporização, $\lambda$, é a quantidade de energia calorífica que deve ser absorvida para quebrar as ligações do hidrogênio entre as moléculas de água no estado líquido para convertê-las em gás. O calor latente de vaporização é uma função da temperatura e pode ser calculado com a equação proposta por Harrison (1963):

$$
\lambda=2,501-2,361 \times 10^{-3} \cdot T_{a v}
$$

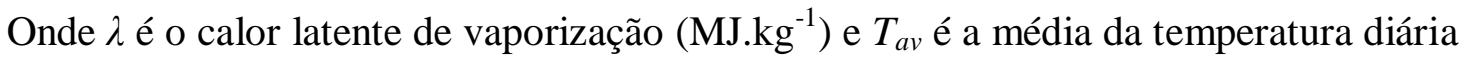
do $\operatorname{ar}\left({ }^{\circ} \mathrm{C}\right)$.

A evaporação envolve a troca de calor latente e calor sensível entre o corpo evaporante e o ar. A constante psicrométrica, $\gamma$, representa um equilíbrio entre o calor sensível ganho através do ar fluindo por um termômetro de bulbo úmido e o calor sensível convertido em calor latente e é calculado pela equação (BRUNT, 1952):

$$
\gamma=\frac{c_{p} \cdot P}{0,622 \cdot \lambda}
$$

Em que $\gamma$ é a constante psicrométrica $\left(\mathrm{kPa}^{\circ} \mathrm{C}^{-1}\right), c_{p}$ é o calor específico de ar úmido numa pressão constante (adotado como $1,013 \times 10^{-3} \mathrm{MJ} \mathrm{kg}^{-1} \cdot{ }^{\circ} \mathrm{C}^{-1}$ ), $P$ é a pressão atmosférica $(\mathrm{kPa})$, e $\lambda$ é o calor latente de vaporização $\left(\mathrm{MJ} \cdot \mathrm{kg}^{-1}\right)$.

O cálculo da constante psicrométrica requer um valor para a pressão atmosférica. $O$ SWAT estima tal valor usando uma equação desenvolvida por Doorenbos e Pruitt (1977) a partir de dados médios de pressão atmosférica em diversos locais da África oriental:

$$
P=101,3-0,01152 \cdot E L+0,544 \times 10^{-6} \cdot E L^{2}
$$

Em que $P$ é a pressão atmosférica $(\mathrm{kPa})$ e $E L$ é a elevação $(\mathrm{m})$. 


\section{Resistência aerodinâmica}

Como uma resistência difusiva, a resistência aerodinâmica pode ser entendida como o tempo decorrido para que uma unidade de volume de ar troque momentum, vapor d'água, calor sensível ou $\mathrm{CO}_{2}$ com uma unidade de área de superfície (MONTEITH, 1965). O cálculo da resistência aerodinâmica no modelo SWAT é dado por:

$$
r_{a}=\frac{\ln \left[\frac{\left(z_{w}-d\right)}{z_{o m}}\right] \ln \left[\frac{\left(z_{p}-d\right)}{z_{o v}}\right]}{k^{2} U_{z}}
$$

Em que $r_{a}$ é a resistência aerodinâmica $\left(\mathrm{s} . \mathrm{m}^{-1}\right), z_{w}$ é a altura de medição da velocidade do vento $(\mathrm{cm}), z_{p}$ é a altura na qual são realizadas as medições de umidade e de temperatura (cm), $d$ é o deslocamento do plano zero do perfil do vento $(\mathrm{cm}), z_{o m}$ é o comprimento de rugosidade para transferência de momentum $(\mathrm{cm}), z_{o v}$ é o comprimento de rugosidade para a transferência de vapor $(\mathrm{cm}), k$ é a constante de von Kármán e $U_{z}$ é a velocidade do vento na altura $z_{w}\left(\mathrm{~m} \cdot \mathrm{s}^{-1}\right)$.

$\mathrm{Na}$ equação 4.21, a altura de medição da velocidade do vento, $z_{w}$, e a altura das medidas de umidade e de temperatura, $z_{p}$, são sempre consideradas como sendo $170 \mathrm{~cm}$, visto que o modelo assume que as informações sobre a velocidade do vento são coletadas de medidores posicionados $1,7 \mathrm{~m}$ acima da superfície do solo.

A altura de deslocamento do plano zero, $d$, é uma correção para a forma do perfil logaritmo do vento próximo à superfície, representando o nível médio de absorção de momentum por uma superfície rugosa. No SWAT é calculada utilizando a seguinte relação (PLATE, 1971; MONTEITH, 1981):

$$
d=2 / 3 \cdot h_{c}
$$

Em que $h_{c}$ é a altura média do dossel da planta $(\mathrm{cm})$. No modelo a altura das plantas é calculada diariamente, tendo como base o ciclo de crescimento vegetal e as condições de manejo adotadas. A obtenção deste parâmetro é abordada nas próximas seções.

Brutsaert (1975) determinou que o parâmetro rugosidade da superfície, $z_{o}$, está relacionado à altura média do dossel da planta, $h_{c}$, pela fórmula $h_{c} / z_{o}=3 e$, em que $e$ é a base 
do logaritmo natural. Baseado nessa relação, o comprimento de rugosidade para transferência de momentum, $z_{o m}$, é calculado como:

$$
\begin{aligned}
& z_{\text {om }}=h_{c} / 8,15=0,123 \cdot h_{c} \quad h_{c} \leq 200 \mathrm{~cm} \\
& z_{\text {om }}=0,058 \cdot\left(h_{c}\right)^{1,19} \quad h_{c}>200 \mathrm{~cm}
\end{aligned}
$$

O conceito de comprimento de rugosidade para a transferência de momentum inclui os efeitos de forças bluff-body ${ }^{1}$. Essas forças não têm nenhum impacto na transferência de calor e vapor, sendo o comprimento de rugosidade para a transferência de vapor, $z_{o v}$, somente uma fração da transferência de momentum. Para estimar $z_{o v}$, Stricker e Brutsaert (1978) propuseram:

$$
z_{o v}=0,1 \cdot z_{o m}
$$

Por fim, o termo $k$ na equação 4.21 refere-se à constante de von Kármán, uma constante adimensional que descreve o perfil de velocidade logarítmica de um fluido submetido a fluxo turbulento. $\mathrm{O}$ valor adotado para esta constante situa-se na faixa de 0,36 a 0,43 (JENSEN; BURMAN; ALLEN, 1990), sendo utilizado no SWAT o valor de 0,41.

Verifica-se que o único parâmetro de entrada utilizado pelo SWAT para o cálculo da resistência aerodinâmica é a velocidade do vento.

\section{Resistência do dossel da planta}

Além da resistência aerodinâmica, o cálculo da evapotranspiração envolve a determinação da resistência foliar à difusão de vapor (resistência do dossel), a qual se traduz em três componentes: a resistência dos espaços intercelulares de ar, a resistência da cutícula e a resistência estomática combinada das folhas da planta. Estudos mostraram que a resistência do dossel para uma safra de referência bem regada pode ser calculada ao dividir a resistência

\footnotetext{
${ }^{1}$ Termo em inglês utilizado para se referir às forças atuantes sobre corpos rombudos. Corpos rombudos ou nãodelgados são corpos que tendem a bloquear o escoamento do fluído no qual se encontram. Geralmente possuem formas cilíndricas ou planas, com grande volume na direção perpendicular à do escoamento, apresentando, em geral, a formação bidimensional de vórtices.
} 
da superfície mínima para uma única folha, $r_{l}$, pela metade do índice da área foliar do dossel, LAI, conforme a equação (JENSEN; BURMAN; ALLEN, 1990):

$$
r_{c}=\frac{r_{l}}{0,5 \cdot L A I}
$$

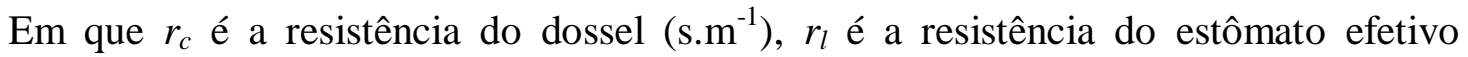
mínimo de uma única folha $\left(\mathrm{s} . \mathrm{m}^{-1}\right)$ e $L A I$ é o índice de área foliar do dossel. O índice de área foliar é definido como sendo a razão entre a área foliar do dossel por unidade de superfície projetada no solo $\left(\mathrm{m}^{2} / \mathrm{m}^{2}\right)$, e seu equacionamento no SWAT é apresentado adiante.

Sabe-se que a condutância de uma determinada folha é definida como o inverso de sua resistência. Assim sendo, a resistência do dossel pode ser representada através da condutância da folha, $g_{l}$, ao invés da resistência da folha, permitindo-se reescrever a equação como:

$$
r_{c}=\left(0,5 \cdot g_{l} \cdot L A I\right)^{-1}
$$

Ao calcular a evapotranspiração real, o termo resistência do dossel é modificado para refletir o impacto do déficit de pressão de vapor limiar na condutância da folha (STOCKLE et al., 1992). Para uma determinada espécie de planta, o déficit de pressão de vapor limiar é definido como o ponto na qual a condutância da folha começa a cair em resposta ao déficit de pressão do vapor. Desse modo, a condutância da folha ajustada é calculada por:

$$
\begin{array}{ll}
g_{l}=g_{l, m x} \cdot\left[1-\Delta g_{l, d c l}\left(v p d-v p d_{t h r}\right)\right\rfloor & \text { se } v p d>v p d_{t h r} \\
g_{l}=g_{l, m x} & \text { se } v p d \leq v p d_{t h r}
\end{array}
$$

Em que $g_{l}$ é a condutância estomática de uma única folha $\left(\mathrm{m} \cdot \mathrm{s}^{-1}\right), g_{l, m x}$ é a máxima condutância estomática de uma única folha $\left(\mathrm{m}^{\mathrm{s}} \mathrm{s}^{-1}\right), \Delta g_{l, d c l}$ é a taxa de diminuição na condutância da folha por unidade de aumento no déficit de pressão de vapor $\left(\mathrm{m}^{-1} \mathrm{~s}^{-1} \cdot \mathrm{kPa}^{-1}\right), v p d$ é o déficit de pressão do vapor (kPa), cujo cálculo foi apresentado na equação 4.17, e $v p d_{t h r}$ é o déficit de pressão do vapor limiar sobre uma planta que exibirá condutância da folha reduzida $(\mathrm{kPa})$. A taxa de diminuição na condutância da folha por unidade que aumenta o déficit de pressão do vapor é calculada pela resolução da equação 4.27 utilizando os valores medidos para a condutância do estômato em dois diferentes déficits de pressão do vapor: 


$$
\Delta g_{l, d c l}=\frac{\left(1-f r_{g, m x}\right)}{\left(v p d_{f r}-v p d_{t h r}\right)}
$$

Em que $\Delta g_{l, d c l}$ é a taxa de diminuição na condutância da folha por unidade de aumento no déficit de pressão no vapor $\left(\mathrm{m}^{-1} \mathrm{~s}^{-1} \cdot \mathrm{kPa}^{-1}\right), f r_{g, m x}$ é a fração da condutância estomática máxima, $g_{l, m x}$, alcançada no déficit de pressão do vapor $v p d_{f r}$, e, por fim, $v p d_{t h r}$ é o déficit de pressão de vapor limiar sobre a qual uma planta exibirá condutância de folha reduzida $(\mathrm{kPa})$. O déficit de pressão de vapor limiar no SWAT é adotado para ser 1,0 kPa para todas as espécies de plantas.

\section{Fluxo de calor do solo}

A liberação ou o armazenamento de calor do solo podem ser significantes em poucas horas, mas são geralmente pequenos de um dia para o outro, visto que o calor armazenado durante as horas de maior insolação é perdido durante a noite. Desse modo, em decorrência da pequena magnitude do fluxo de calor do solo em relação ao saldo de radiação diário, o modelo SWAT supõe que o fluxo de calor diário do solo, $G$, é sempre igual a zero.

\section{Termo combinado}

Finalmente, o termo combinado $K_{l} \cdot 0,622 \cdot \lambda\left(\rho_{\text {air }} / P\right)$ da equação de Penman-Monteith é obtido isolando-se o parâmetro $c_{p}$ na equação 4.19 , onde $K_{l}$ é um coeficiente dimensional necessário para assegurar que os termos tenham a mesma unidade. Os valores deste coeficiente são adotados conforme as unidades de medida da velocidade do vento, sendo 8,64 x $10^{4}$ para $U_{z}$ em m.s ${ }^{-1}$ e $10^{3}$ para $U_{z}$ em km.d $\mathrm{d}^{-1}$.

No SWAT o termo combinado é calculado a partir de sua relação com a temperatura média diária, $T_{a v}$, conforme formulado por Jensen, Burman e Allen (1990):

$$
K_{1} \cdot 0,622 \cdot \lambda \cdot \frac{\rho_{\text {air }}}{P}=1710-6,85 \cdot T_{a v}
$$




\subsubsection{Equações relacionadas ao crescimento da planta}

Conforme visto na seção anterior, o cálculo da evapotranspiração potencial no SWAT envolve a determinação de propriedades relacionadas ao crescimento das plantas, como a altura do dossel, $h_{c}$, e o índice de área foliar, LAI. Normalmente os métodos de cálculo da evapotranspiração utilizam valores médios para essas variáveis conforme o tipo de cultura, sendo tais valores obtidos na literatura. Já na formulação do modelo SWAT, o crescimento potencial da planta é calculado diariamente durante todo o período simulado. Desse modo, tais parâmetros de crescimento são obtidos para cada dia de simulação, variando continuamente conforme as etapas do ciclo de crescimento da cultura e a energia disponível.

Dentre os fatores que regem o crescimento das plantas, a temperatura é um dos mais importantes. Cada espécie vegetal possui uma faixa de temperatura ótima para o crescimento, na qual uma temperatura mínima (denominada temperatura de base) deve ser alcançada para que o crescimento aconteça. Desse modo, para que haja crescimento vegetal é necessário um determinado acúmulo térmico representado pelo somatório da diferença entre as temperaturas médias diárias e a temperatura de base. Tais necessidades térmicas são contabilizadas para cada estágio de desenvolvimento da planta na forma de Unidades de Calor (Heat Units - HU). O acúmulo de unidades de calor em um determinado dia é calculado por:

$$
H U=T_{a v}-T_{b a s e}
$$

Em que $H U$ é o número de unidades de calor acumuladas em um determinado dia, $T_{a v}$ é a temperatura média diária $\left({ }^{\circ} \mathrm{C}\right)$, e $T_{\text {base }}$ é a temperatura de base ou mínima que a planta requer para que haja crescimento $\left({ }^{\circ} \mathrm{C}\right)$. É importante ressaltar que há crescimento apenas quando $T_{a v}>T_{b a s e}$, ou seja, quando a temperatura média diária é superior à temperatura de base. O número total de unidades de aquecimento necessárias para que a planta atinja a maturidade é calculado por:

$$
P H U=\sum_{d=1}^{m} H U
$$

Em que $P H U$ é o total de unidades de aquecimento necessárias para que a planta atinja maturidade, $H U$ é o número de unidades de aquecimento acumuladas no dia $d$, sendo $\mathrm{d}=1$ no 
dia do plantio, e $m$ é o número de dias necessários para que a planta atinja a maturidade. Para a maioria dos cultivos, o número de dias para atingir a maturidade, $m$, bem como o total de unidades de calor necessárias, $P H U$, são conhecidos.

Na Figura 9 é apresentado como se dá a variação da altura do dossel e do índice de área foliar durante o desenvolvimento das plantas anuais e perenes no modelo SWAT. O exemplo em questão é ilustrado usando parâmetros referentes à cultura Alamo Switchgrass ${ }^{1}$.
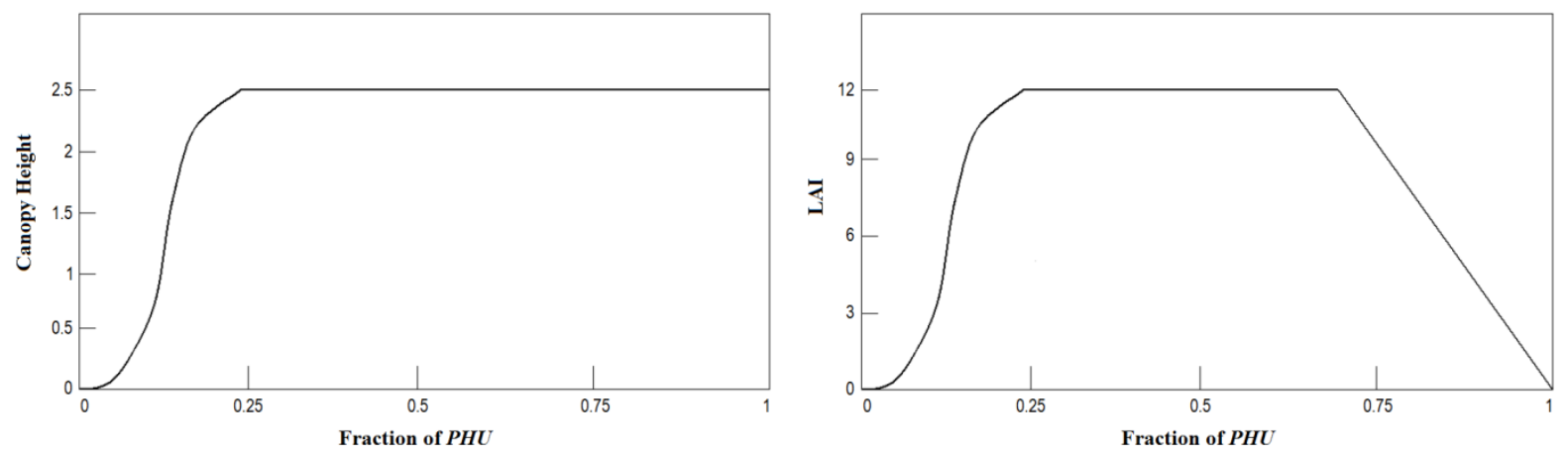

Figura 9 - Variação na altura do dossel (esq.) e no índice de área foliar (dir.) durante o desenvolvimento da planta no modelo SWAT.

No período inicial de crescimento de uma determinada planta, a altura do dossel e o crescimento da área foliar são controlados pela curva de desenvolvimento ideal da área foliar, dada pela equação:

$$
f r_{L A \operatorname{Im} x}=\frac{f r_{P H U}}{f r_{P H U}+\exp \left(\ell_{1}-\ell_{2} . f r_{P H U}\right)}
$$

Na qual $f r_{\text {LAImx }}$ é a fração do índice máximo da área foliar da planta correspondente a uma fração atribuída de potenciais unidades de calor, $f r_{P H U}$ é a fração de potenciais unidades de calor acumuladas para a planta em um determinado dia na fase vegetativa e $\ell_{1}$ e $\ell_{2}$ são coeficientes de forma. A fração de potenciais unidades de calor acumuladas até uma determinada data (dia $d$ ) é calculada por:

\footnotetext{
1 Alamo Switchgrass (Panicum virgatum L.) é uma espécie de capim comumente encontrada nas grandes planícies e pradarias dos Estados Unidos. É uma gramínea perene de verão que possui cerca de 1 a $1,5 \mathrm{~m}$ de altura e tem alto potencial para uso como biocombustível.
} 


$$
f r_{P H U}=\frac{\sum_{i=1}^{d} H U_{i}}{P H U}
$$

Em que $f r_{P H U}$ é a fração de potenciais unidades de calor acumuladas para a planta no dia $d$ na fase vegetativa, $H U$ é a unidade de calor acumulada no dia $i$ (unidades de calor) e $P H U$ é o total de potenciais unidades de calor para a planta (unidades de calor). Os coeficientes de forma $\ell_{1}$ e $\ell_{2}$ são calculados pela solução da equação 4.32 utilizando dois pontos conhecidos $\left(f r_{L A I, 1}, f r_{P H U, 1}\right)$ e $\left(f r_{L A I, 2}, f r_{P H U, 2}\right)$ :

$$
\begin{aligned}
& \ell_{1}=\ln \left(\frac{f r_{P H U, 1}}{f r_{L A I, 1}}-f r_{P H U, 1}\right)+\ell_{2} \cdot f r_{P H U, 1} \\
& \ell_{2}=\frac{\left[\ln \left(\frac{f r_{P H U, 1}}{f r_{L A I, 1}}-f r_{P H U, 1}\right)-\ln \left(\frac{f r_{P H U, 2}}{f r_{L A I, 2}}-f r_{P H U, 2}\right)\right]}{f r_{P H U, 2}-f r_{P H U, 1}}
\end{aligned}
$$

Em que $\ell_{1}$ é o primeiro coeficiente de forma, $\ell_{2}$ é o segundo coeficiente de forma, $f r_{P H U, 1}$ é a fração da fase vegetativa (ou seja, fração das potenciais unidades de calor totais) correspondente ao $1^{\circ}$ ponto na curva ideal do desenvolvimento da área foliar, $f r_{L A l, l}$ é a fração do índice máximo da área foliar da planta (ou seja, fração da $L A I_{m x}$ ) correspondente ao $1^{\circ}$ ponto na curva de desenvolvimento ideal da área foliar, $f r_{P H U, 2}$ é a fração da fase vegetativa correspondente ao $2^{\circ}$ ponto da curva de desenvolvimento ideal da área foliar, $f r_{L A l, 2}$ é a fração do índice máximo da área foliar da planta correspondente ao $2^{\circ}$ ponto na curva de desenvolvimento ideal da área foliar.

Sabendo-se a fração do índice máximo da área foliar correspondente a uma fração atribuída de potenciais unidades de calor para a planta, $f r_{L A I m x}$, a altura da copa da planta em um determinado dia é calculada por:

$$
h_{c}=h_{c, m x} \cdot \sqrt{f r_{L A \operatorname{Im} x}}
$$

$\mathrm{Na}$ qual $h_{c}$ é a altura da copa da árvore em um determinado dia $(\mathrm{m}), h_{c, m x}$ é a altura máxima da copa (dossel) da planta $(\mathrm{m})$, e $f r_{L A I m x}$ é a fração do índice máximo da área foliar 
correspondente a uma fração determinada de potenciais unidades de calor para a planta. Como pode ser visto na Figura 9, uma vez que a altura máxima da copa da árvore é alcançada, $h_{c}$ permanecerá constante até que a planta morra ou seja colhida.

A quantificação do volume do dossel é expressa através do índice de área foliar, o qual é calculado diariamente pelo modelo. Para plantas anuais e perenes, a área foliar adicionada em determinado dia $i$ é calculada por:

$$
\Delta L A I_{i}=\left(f r_{L A I m x, i}-f r_{L A I m x, i-1}\right) \cdot L A I_{m x} \cdot\left\{1-\exp \left[5 \cdot\left(L A I_{i-1}-L A I_{m x}\right)\right]\right\}
$$

Enquanto para as árvores, a área foliar adicionada no dia $i$ é calculada por:

$$
\begin{aligned}
& \Delta L A I_{i}=\left(f r_{L A I m x, i}-f r_{\text {LAImx }, i-1}\right) \cdot\left(\frac{y r_{\text {cur }}}{y r_{\text {fulldev }}}\right) \cdot L A I_{m x} . \\
& \left\{1-\exp \left[5 \cdot\left(L A I_{i-1}-\left(\frac{y r_{\text {cur }}}{y r_{\text {fulldev }}}\right) \cdot L A I_{m x}\right)\right]\right\}
\end{aligned}
$$

O índice de área foliar total em determinado dia $i$, em ambas as situações, é calculado por:

$$
L A I_{i}=L A I_{i-1}+\Delta L A I_{i}
$$

Em que $\triangle L A I_{i}$ é a área foliar adicionada no dia $i, L A I_{i}$, e $L A I_{i-1}$, são os índices da área foliar para o dia $i$ e $i-1$ respectivamente, $f r_{L A I m x, i}$ e $f r_{L A I m x, i-1}$ são as frações do índice máximo da área foliar da planta calculados com a equação 4.32 para o dia $i$ e $i-1, L A I_{m x}$ é o índice de área foliar máximo para a planta, $y r_{c u r}$ é a idade da árvore (anos) e $y r_{\text {fulldev }}$ é o número de anos para a espécie de árvore alcançar o desenvolvimento pleno (anos).

As variáveis $f r_{P H U, 1}, f r_{P H U, 2}, f r_{L A I, 1}, f r_{L A I, 2}$ e $L A I_{m x}$ apresentadas acima são computacionalmente traduzidas na forma dos parâmetros FRGRW1, FRGRW2, LAIMX1, LAIMX2 e BLAI do banco de dados de crescimento vegetal do SWAT (arquivo geral plant.dat). Tais parâmetros possuem valores pré-determinados compilados a partir da literatura norte-americana, porém podem ser editados pelo usuário. 


\subsubsection{Evapotranspiração real}

Depois de determinada a evapotranspiração potencial e definido o estágio de desenvolvimento da planta, a evapotranspiração real pode ser estimada. Em um primeiro momento, o SWAT evapora qualquer precipitação que tenha sido interceptada pelo dossel da planta. Em seguida, o modelo calcula a quantidade máxima de transpiração e a quantidade máxima de evaporação do solo utilizando uma abordagem similar a de Ritchie (1972). Caso haja presença de neve na HRU ocorrerá o processo de sublimação; quando não há ocorrência de neve, ocorrem os processos de evaporação do solo. Tais processos são rapidamente abordados nas seções seguintes.

\section{Evaporação de precipitações interceptadas}

Qualquer quantidade de água livre presente no dossel das plantas está prontamente disponível para ser removida por evapotranspiração. A quantidade de precipitação interceptada que contribui para a evapotranspiração real é bastante significante nas florestas, podendo em alguns casos ser até maior do que a própria transpiração das plantas.

O modelo SWAT remove a maior quantidade possível de água armazenada no dossel ao calcular a evaporação real. Se a evapotranspiração potencial, $E_{O}$, for menor que a umidade armazenada dentro do dossel, $R_{I N T}$, então:

$$
\begin{aligned}
& E_{a}=E_{c a n}=E_{O} \\
& R_{I N T(f)}=R_{I N T(i)}-E_{c a n}
\end{aligned}
$$

Em que $E_{a}$ é a evapotranspiração real que ocorre na bacia hidrográfica em um determinado dia $\left(\mathrm{mm} \mathrm{H}_{2} \mathrm{O}\right), E_{c a n}$ é a quantidade de evaporação de água livre armazenada no dossel em um determinado dia $\left(\mathrm{mm} \mathrm{H}_{2} \mathrm{O}\right), E_{O}$ é a evapotranspiração potencial em um determinado dia $\left(\mathrm{mm} \mathrm{H}_{2} \mathrm{O}\right), R_{I N T(i)}$ é a quantidade inicial de água livre armazenada dentro do dossel em um determinado dia $\left(\mathrm{mm}_{2} \mathrm{O}\right)$ e $R_{I N T(f)}$ é a quantidade final de água livre armazenada dentro do dossel em um determinado dia $\left(\mathrm{mm} \mathrm{H}_{2} \mathrm{O}\right)$. Se a evapotranspiração potencial, $E_{O}$, for maior que a quantidade de água armazenada dentro do dossel, $R_{I N T}$, então: 


$$
\begin{aligned}
& E_{c a n}=R_{I N T(i)} \\
& R_{I N T(f)}=0
\end{aligned}
$$

Uma vez que a quantidade de água livre dentro do dossel foi evaporada, a demanda de água evaporativa restante $\left(E_{O}{ }^{\prime}=E_{O}-E_{c a n}\right)$ é dividida entre a vegetação e o solo.

\section{Transpiração}

A transpiração é calculada pelo SWAT em função do índice de área foliar da planta e da evapotranspiração potencial ajustada, sendo dada por:

$$
\begin{array}{ll}
E_{T}=\frac{E_{O}{ }^{\prime} \cdot L A I}{3,0} & 0 \leq L A I \leq 3,0 \\
E_{T}=E_{O}{ }^{\prime} & L A I>3,0
\end{array}
$$

Em que $E_{T}$ é a transpiração máxima em um determinado dia $(\mathrm{mm} \mathrm{H} 2 \mathrm{O}), E_{O}{ }^{\prime}$ é a evapotranspiração potencial ajustada para a evaporação de água livre do dossel (mm H2O) e LAI é o índice de área foliar. $\mathrm{O}$ valor calculado pelas equações 4.44 e 4.45 é a quantidade de transpiração que ocorrerá em um determinado dia quando a planta está crescendo sob condições ideais. A quantidade real de transpiração pode ser menor devido à falta de água disponível no perfil do solo.

\section{Evaporação da água no solo}

A quantidade de água evaporada a partir do solo será impactada pelo grau de sombreamento ocasionado pela vegetação. A quantidade máxima de evaporação em um determinado dia é calculada como:

$$
E_{S}=E_{O} \cdot \operatorname{cov} v_{\text {sol }}
$$


Em que $E_{S}$ é a evaporação máxima do solo em um determinado dia (mm), $E_{O}{ }^{\prime}$ é a evapotranspiração potencial ajustada para evaporação de água livre dentro dossel (mm), e $\operatorname{cov}_{s o l}$ é o índice de cobertura do solo. O índice de cobertura do solo é obtido conforme a equação 4.10, apresentada anteriormente.

A quantidade máxima de água evaporada do solo é reduzida durante os períodos de elevado uso de água pela planta a partir da relação:

$$
E_{S}{ }^{\prime}=\min \left(E_{S}, \quad \frac{E_{S} \cdot E_{O}{ }^{\prime}}{E_{S}+E_{T}}\right)
$$

Em que $E_{s}{ }^{\prime}$ é a evaporação máxima do solo ajustada para o uso da água pela planta em um determinado dia (mm), Es é a evaporação máxima do solo em um determinado dia (mm), $E o^{\prime}$ é a evapotranspiração potencial ajustada para a evaporação de água livre no dossel (mm) e $E_{T}$ é a transpiração em um determinado dia (mm). Quando $E_{T}$ for baixo, $E_{S}{ }^{\prime} \rightarrow E_{S}$. No entanto, quanto $E_{T}$ aproxima de $E o^{\prime}, E_{S}{ }^{\prime} \rightarrow E_{S} /\left(1+\operatorname{cov}_{s o l}\right)$.

Quando uma demanda de evaporação para a água do solo existe, o SWAT primeiro deve dividir a demanda evaporativa entre as diferentes camadas. A distribuição da profundidade utilizada para determinar a quantidade máxima de água permitida para ser evaporada é:

$$
E_{\text {soil,z }}=E_{s}^{\prime \prime} \cdot \frac{z}{z+\exp (2,374-0,00713 \cdot z)}
$$

Em que $E_{s o i l, z}$ é a demanda evaporativa na profundidade $z(\mathrm{~mm}), E_{s}{ }^{\prime \prime}$ é a evaporação máxima da água do solo em um determinado dia $(\mathrm{mm})$ e $z$ é a profundidade abaixo da superfície. Os coeficientes nessa equação foram selecionados para que 50\% da demanda evaporativa seja extraída dos primeiros $10 \mathrm{~mm}$ de solo e $95 \%$ da demanda evaporativa seja extraída dos primeiros $100 \mathrm{~mm}$ de solo.

\subsection{Dados de entrada e configurações adotadas nas simulações iniciais}

Para as simulações utilizou-se a versão 2012.10.1.15 da extensão ArcSWAT, a qual permite integração com o software ArcGIS 10.1, da ESRI. Visando representar toda a heterogeneidade existente nos sistemas modelados, o SWAT trabalha com uma grande 
quantidade de dados espaciais e não espaciais referentes à topografia, aos tipos de solo, uso da terra, clima, dentre outros. Nas próximas seções serão descritos os procedimentos realizados na aquisição e preparação dos dados de entrada para as simulações nas cinco bacias apresentadas.

\subsubsection{Dados topográficos}

A etapa inicial de simulação no SWAT consiste na delimitação da bacia de drenagem e na sua divisão em sub-bacias, procedimento realizado com base na topografia da área em questão. Para tal, nesta primeira etapa o simulador requer como dado de entrada o Modelo Digital de Elevação (MDE) envolvendo os limites da bacia.

Nas bacias de menor extensão B1 (Córrego Cana-do-Reino), B2 (Ribeirão do Feijão) e B3 (Ribeirão Mandaguari) o MDE foi gerado a partir de mapeamentos topográficos em diferentes escalas, os quais tiveram as feições de suas cartas digitalizadas e vetorizadas. Por meio da extensão 3D Analyst do ArcGIS, as curvas de nível e pontos cotados foram utilizados para a geração da grade TIN (Triangulated Irregular Network), a qual posteriormente foi convertida para o formato raster, gerando o DEM para cada uma das bacias.

Já nas bacias maiores, B4 (Rio do Pari) e B5 (Alto Paranapanema), foram utilizados dados provenientes do projeto Shuttle Radar Topography Mission (SRTM), executado pela NASA e disponibilizado pelo Serviço Geológico dos Estados Unidos (USGS). Foram selecionados os modelos de elevação nos quais se inserem as áreas de estudo, realizando-se o posterior recorte destes. Na Tabela 5 é apresentada a síntese com a descrição de todas as fontes de obtenção dos dados altimétricos utilizados neste trabalho, para cada uma das cinco bacias.

No processo de divisão em sub-bacias, o SWAT adiciona automaticamente os pontos de confluência da rede hidrográfica, os quais passam a representar os exutórios referentes a cada sub-bacia gerada. A partir do DEM, é realizada a determinação da direção do fluxo para cada pixel, permitindo delimitar a área que contribui com escoamento superficial em cada ponto da rede hidrográfica. Nesta etapa, é permitido ao usuário inserir ou remover pontos de interesse em qualquer trecho da rede hidrográfica, podendo desta forma definir o número de sub-bacias a serem geradas, bem como o exutório da bacia principal 
Tabela 5 - Fontes de obtenção dos dados altimétricos.

\begin{tabular}{|c|c|c|}
\hline Bacia & Levantamento utilizado & Articulação das folhas / Identificador das imagens \\
\hline B1 & $\begin{array}{l}\text { Modelo digital de superfície em } \\
\text { escala 1:10.000 executado pelo } \\
\text { Projeto Mapeia São Paulo }\end{array}$ & $\begin{aligned} \text { SF-22-X-A-II-4-SE, } & \text { SF-22-X-A-III-3-SO, SF-22-X-A-VI-1-NO } \\
& \text { e SF-22-X-A-V-2-NE }\end{aligned}$ \\
\hline B2 & $\begin{array}{l}\text { Mapeamento topográfico em escala } \\
\text { 1:10.000 executado pelo Instituto } \\
\text { Geográfico e Cartográfico de São } \\
\text { Paulo (1978). Equidistância de } \\
\text { curvas de nível de } 5 \mathrm{~m} .\end{array}$ & $\begin{array}{l}\text { São Carlos I (SF-23-Y-A-I-1-NO-B); São Carlos II (SF-23-Y-A- } \\
\text { I-1-NE-A); São Carlos IV (SF-23-Y-A-I-1-NO-D); Faz. Capão } \\
\text { de Antas (SF-23-Y-A-I-1-NE-C); Faz. Água Turva (SF-23-Y-A- } \\
\text { I-1-NE-D); Faz. Córrego Seco (SF-23-Y-A-I-2-NO-C); Córr. } \\
\text { Santa Maria (SF-23-Y-A-I-1-NO-F); Est. Conde do Pinhal (SF- } \\
\text { 23-Y-A-I-1-NE-E); Morrinho (SF-23-Y-A-I-1-NE-F); Serra da } \\
\text { Estrela (SF-23-Y-A-I-2-NO-E); Rio Jacaré-Guaçu (SF-23-Y-A-I- } \\
\text { 1-SO-B); Faz. Conde do Pinhal (SF-23-Y-A-I-1-SE-A); Est. } \\
\text { Visconde do Rio Branco (SF-23-Y-A-I-1-SE-B); Rio Corumbataí } \\
\text { (SF-23-Y-A-I-2-SO-A); Represa do Lobo (SF-23-Y-A-I-1-SO- } \\
\text { D); Córrego do Geraldo (SF-23-Y-A-I-1-SE-C); Faz. São José } \\
\text { (SF-23-Y-A-I-1-SE-D); Faz. Mutuca II (SF-23-Y-A-I-1-SE-F) }\end{array}$ \\
\hline B3 & $\begin{array}{c}\text { Mapeamento topográfico em escala } \\
\text { 1:50.000 executado pelo Instituto } \\
\text { Brasileiro de Geografia e Estatística } \\
\text { (1974). Equidistância de curvas de } \\
\text { nível de } 20 \mathrm{~m} \text {. }\end{array}$ & $\begin{array}{l}\text { Alfredo Marcondes (SF-22-V-D-VI-3); Mariápolis (SF-22-V-D- } \\
\text { VI-4); Presidente Prudente (SF-22-Y-B-III-1); Martinópolis (SF- } \\
\text { 22-Y-B-III-2) }\end{array}$ \\
\hline B4 & $\begin{array}{l}\text { Imagem SRTM de resolução } 30 \text { m } \\
\text { (1 arco-segundo), disponibilizada } \\
\text { pelo Serviço Geológico dos Estados } \\
\text { Unidos (USGS) }\end{array}$ & Imagem SRTM1 S23W051V3 \\
\hline B5 & $\begin{array}{l}\text { Imagens SRTM de resolução } 90 \mathrm{~m} \\
\text { (3 arco-segundos), disponibilizadas } \\
\text { pelo Serviço Geológico dos Estados } \\
\text { Unidos (USGS) }\end{array}$ & $\begin{array}{l}\text { Imagens SRTM1 S24W048V3; SRTM1 S24W049V3; SRTM1 } \\
\text { S25W048V3; SRTM1 S25W049V3. }\end{array}$ \\
\hline
\end{tabular}

\subsubsection{Dados pedológicos}

Em relação aos dados de entrada referentes aos solos, o simulador exige tanto dados espaciais, representando a distribuição das unidades pedológicas em uma determinada bacia, quanto dados tabulares, indicativos das características físico-hídricas dos tipos de solo presentes no respectivo mapeamento.

Realizou-se uma compilação de levantamentos pedológicos de forma que as escalas de detalhamento fossem compatíveis com as áreas das bacias, onde os levantamentos selecionados são apresentados na Tabela 6. Para cada um dos levantamentos, foi realizada a vetorização dos limites das classes de solo e a transformação para raster, formato exigido pelo SWAT. 
Tabela 6 - Levantamentos pedológicos utilizados nas simulações.

\begin{tabular}{clc}
\hline Bacia & \multicolumn{1}{c}{ Levantamento pedológico utilizado } & \multicolumn{1}{c}{$\begin{array}{c}\text { Escala de } \\
\text { detalhamento }\end{array}$} \\
\hline B1 & $\begin{array}{l}\text { Levantamento pedológico detalhado da microbacia do Córrego Cana- } \\
\text { do-Reino (VILLELA, 2015) }\end{array}$ & $1: 50.000$ \\
B2 & $\begin{array}{l}\text { Levantamento pedológico semi-detalhado do Estado de São Paulo. } \\
\text { Quadrícula de São Carlos, Folha SF 23-Y-A-I. (OLIVEIRA; PRADO, } \\
\text { 1984) }\end{array}$ & $1: 100.000$ \\
B3 & $\begin{array}{l}\text { Mapa pedológico do Estado de São Paulo. Folha I (OLIVEIRA } \text { et al., } \\
\text { 1999) }\end{array}$ & $1: 500.000$ \\
B4 & $\begin{array}{l}\text { Mapa pedológico do Estado de São Paulo. Folha III (OLIVEIRA et } \\
\text { al., 1999) } \\
\text { Mapa pedológico do Estado de São Paulo. Folha IV (OLIVEIRA et } \\
\text { al., 1999) }\end{array}$ & $1: 500.000$ \\
\hline
\end{tabular}

Visando a padronização taxonômica, foi realizada a conversão da nomenclatura das classes de solo dos mapeamentos antigos para o atual Sistema Brasileiro de Classificação de Solos (EMBRAPA, 2006), sendo considerado até o terceiro nível categórico de classificação. Tal conversão foi realizada em função das características químicas das unidades pedológicas encontradas nas bacias, conforme informações obtidas nos memoriais descritivos referentes aos respectivos levantamentos. Em compartimentos pedológicos onde havia ocorrência de associações de dois ou mais tipos de solo, considerou-se apenas a unidade predominante, conforme apontado na legenda do mapa original.

Os dados tabulares exigidos pelo SWAT compreendem 15 parâmetros físico-hídricos relativos a cada uma das classes de solo existentes nos mapas, sendo tais valores obtidos a partir da literatura ou estimados. Segundo Neitsch et al. (2011), tais parâmetros refletem as características físicas do solo, as quais governam o movimento da água e ar através do perfil e têm importante impacto na circulação da água dentro de uma sub-bacia.

Os parâmetros número de camadas do perfil (NLAYERS), profundidade máxima da raiz no solo (SOL_ZMX), porosidade do solo (ANION_EXCL), profundidade de cada horizonte (SOL_Z), densidade aparente (SOL_BD), teor de carbono orgânico (SOL_CBN) e porcentagens de argila (CLAY), silte (SILT), areia (SAND) e cascalho (ROCK) foram extraídos dos memoriais descritivos referentes aos levantamentos (OLIVEIRA; PRADO, 1984; OLIVEIRA et al., 1999; VILLELA, 2015).

Para o parâmetro grupo hidrológico do solo (HYDGRP), utilizou-se a classificação hidrológica para os solos do estado de São Paulo proposta por Lombardi Neto et al. (1989). 
Os parâmetros capacidade de água disponível (SOL_AWC) e condutividade hidráulica saturada (SOL_K) foram estimados a partir de sua relação com as características texturais e o teor de carbono orgânico, segundo metodologia apresentada por Saxton e Rawls (2006).

O parâmetro Fator K da USLE (USLE_K), referente à suscetibilidade de um determinado solo à erosão, foi calculado através da metodologia proposta por Williams (1995), a qual estima valores de erodibilidade com base nas características texturais e no teor de carbono orgânico. Por fim, o parâmetro albedo do solo (SOL_ALB), indicativo da parcela da radiação solar que é refletida de volta para a atmosfera ao atingir a superfície do solo, foi obtido através do trabalho de Biesbrouck et al. (2002).

\subsubsection{Uso da terra}

De modo semelhante às informações referentes aos solos, os dados referentes aos tipos de uso e cobertura da terra ${ }^{1}$ necessários para alimentação do modelo constituem-se em dados espaciais e tabulares.

A geração dos mapeamentos de uso da terra nas áreas de estudo foi realizada por meio da extração de informações de produtos obtidos por sensoriamento remoto, utilizando-se para tal imagens de satélite e ortofotos. Na Tabela 7 são descritos os tipos de produtos utilizados com a indicação do respectivo sensor de origem, a resolução espacial das imagens, a órbita e ponto das cenas, no caso de imagens obtidas por satélite, e a data de tomada das cenas selecionadas. Tais imagens foram disponibilizadas através dos sites do Instituto Nacional de Pesquisas Espaciais (INPE), no caso das imagens do satélite CBERS, e do United States Geological Survey (USGS), no caso das imagens do satélite Landsat. Já as ortofotos foram obtidas junto ao Projeto Mapeia São Paulo, executado pela Empresa Paulista de Planejamento Metropolitano SA (EMPLASA).

Para a bacia B1, a geração do mapa de uso da terra se deu a partir da interpretação visual e vetorização manual tendo como base a ortofoto, visto que se trata de uma área relativamente pequena. Para as demais bacias, recorreu-se ao processo de classificação supervisionada de imagens multiespectrais obtidas por satélite. Inicialmente realizou-se o

\footnotetext{
${ }^{1}$ Neste trabalho, o termo uso da terra refere-se à forma com que a terra está sendo ocupada pelo ser humano ou às atividades humanas ou funções econômicas associadas com uma parcela da terra. Já o termo cobertura da terra relaciona-se aos tipos de feições e de objetos presentes sobre a superfície, sem estarem necessariamente ligados a atividades humanas.
} 
georreferenciamento e tratamento radiométrico destas imagens no software SPRING 5.1, de forma a possibilitar a classificação das mesmas. Utilizou-se o método de classificação supervisionada por pixel, onde foram indicadas amostras dos tipos de usos e coberturas existentes na bacia, a partir das quais o software detectou, através de algoritmos estatísticos, pixels com assinaturas espectrais semelhantes aos pixels das amostras. Foi utilizado neste processo o classificador por máxima verossimilhança Maxver, com limiar de aceitação de $99 \%$.

Tabela 7 - Produtos de sensoriamento remoto utilizados.

\begin{tabular}{|c|c|c|c|c|}
\hline Bacia & Produtos & $\begin{array}{l}\text { Resolução } \\
\text { espacial }\end{array}$ & $\begin{array}{l}\text { Órbita/Ponto da(s) } \\
\text { cena }(s)\end{array}$ & $\begin{array}{l}\text { Data de tomada } \\
\text { da(s) cena }(s)\end{array}$ \\
\hline B1 & $\begin{array}{c}\text { Ortofoto obtida por câmera } \\
\text { Ultracam Xp }\end{array}$ & $1 \mathrm{~m}$ & Não se aplica & $2010-2011$ \\
\hline B2 & $\begin{array}{l}\text { Imagem CBERS-2B / } \\
\text { Instrumento CCD }\end{array}$ & $20 \mathrm{~m}$ & Órbita 155 / Ponto 125 & $02 / 02 / 2010$ \\
\hline \multirow{2}{*}{ B3 } & \multirow{2}{*}{$\begin{array}{l}\text { Duas imagens CBERS-4 / } \\
\text { Instrumento MUX }\end{array}$} & \multirow{2}{*}{$20 \mathrm{~m}$} & Órbita 160 / Ponto 121 & $19 / 01 / 2015$ \\
\hline & & & Órbita 160 / Ponto 122 & $19 / 01 / 2015$ \\
\hline B4 & $\begin{array}{c}\text { Imagem Landsat } 8 \text { / Instrumento } \\
\text { OLI }\end{array}$ & $30 \mathrm{~m}$ & Órbita 221 / Ponto 076 & $19 / 07 / 2015$ \\
\hline \multirow{2}{*}{ B5 } & \multirow{2}{*}{$\begin{array}{l}\text { Duas imagens Landsat } 8 \text { / } \\
\text { Instrumento OLI }\end{array}$} & \multirow{2}{*}{$30 \mathrm{~m}$} & Órbita 220 / Ponto 076 & $13 / 08 / 2015$ \\
\hline & & & Órbita 220 / Ponto 077 & $13 / 08 / 2015$ \\
\hline
\end{tabular}

As classes de uso e cobertura da terra definidas variaram conforme sua presença em cada uma das bacias, sendo elas: mata, reflorestamento, pastagem, cana-de-açúcar, milho, seringal, culturas genéricas, área urbanizada, área urbanizada de baixa densidade e corpos d'água. Após o processamento das imagens, foi realizado o refinamento e aferição do resultado através de sua comparação visual com imagens de alta resolução disponíveis no software Google Earth, sendo realizada a edição matricial do resultado de forma a corrigir possíveis inconsistências ocorridas durante o processo de classificação.

Em relação aos dados tabulares, o modelo trabalha com uma grande quantidade de informações relacionadas à fisiologia vegetal, ao crescimento das culturas e à ciclagem de nutrientes, bem como parâmetros hidrológicos relacionados ao escoamento e infiltração. Por serem atributos de caracterização complexa e de grande dificuldade de obtenção na literatura, as aplicações do SWAT em bacias brasileiras geralmente utilizam os valores já incluídos no 
banco de dados original do modelo (default), os quais são compilados a partir da literatura norte-americana.

$\mathrm{Na}$ versão 2012 do SWAT tal banco de dados (arquivo plant.dat) possui 127 categorias de usos da terra relacionadas a diversos tipos de culturas agrícolas, feições naturais e coberturas específicas, com valores padrão para os parâmetros referentes a cada categoria de uso da terra. Para as áreas urbanizadas, o simulador também possui 9 categorias distintas relacionadas ao tipo de urbanização (residencial, comercial, industrial, dentre outras) e à densidade de edificações.

Desse modo, para cada um dos tipos de uso e cobertura da terra dos mapas gerados, foram associadas categorias presentes no banco de dados do simulador, tentando-se manter o maior nível de similaridade possível em relação à estrutura e fisionomia das classes. A associação entre os usos da terra existentes nas bacias e as categorias presentes no SWAT é apresentada na Tabela 8. Na mesma tabela também é apresentada a classificação em relação ao tipo de planta considerado pelo modelo, o qual permite diferenciá-las em sete categorias diferentes: leguminosa anual de estação quente, leguminosa anual de estação fria, leguminosa perene, anuais de estação quente, anuais de estação fria, perenes e árvores. Tal diferenciação permite que determinados processos sejam simulados de maneira distinta para cada tipo de planta, a exemplo da fixação de nitrogênio e da indução de dormência.

Tabela 8 - Associação entre as classes de uso e ocupação do solo da bacia e os tipos de cobertura do solo disponíveis no banco de dados do SWAT.

\begin{tabular}{lcc}
\hline $\begin{array}{c}\text { Classes de uso da } \\
\text { terra nas bacias }\end{array}$ & $\begin{array}{c}\text { Classes no banco de dados do } \\
\text { SWAT }\end{array}$ & $\begin{array}{c}\text { Classificação do tipo de } \\
\text { planta no SWAT }\end{array}$ \\
\hline Mata & Forest-Mixed (FRST) & Árvore \\
Eucalipto & Eucalyptus (EUCA) & Árvore \\
Pastagem & Pasture (PAST) & Perene \\
Cana-de-açúcar & Sugarcane (SUGC) & Perene \\
Milho & Corn (CORN) & Anual de estação quente \\
Seringueira & Rubber Trees (RUBR) & Árvore \\
Agricultura genérica & Agricultural Land-Generic (AGRL) & Anual de estação quente \\
$\begin{array}{l}\text { Área urbanizada } \\
\text { Área urbanizada } \\
\text { baixa densidade }\end{array}$ & Residential (URBN) & Não se aplica \\
Corpos d'água & Residential-Low Density (URLD) & Não se aplica \\
\hline
\end{tabular}




\subsubsection{Dados climáticos e configuração das simulações}

A inserção de séries meteorológicas consistentes e representativas é de grande importância no processo de modelagem, visto que os processos hidrológicos são fortemente influenciados por tais componentes.

Os dados climáticos necessários para simulação no SWAT são séries diárias de precipitação $\left(\mathrm{mm} \mathrm{H}_{2} \mathrm{O}\right)$, de temperaturas máxima e mínima $\left({ }^{\circ} \mathrm{C}\right)$, de umidade relativa $(\%)$, de velocidade do vento $(\mathrm{m} / \mathrm{s})$ e de radiação solar $\left(\mathrm{MJ} / \mathrm{m}^{2}\right.$.dia). Tais informações foram compiladas a partir das bases de dados do Sistema de Informações Hidrológicas HidroWeb, da Agência Nacional de Águas (ANA), do Banco de Dados Hidrológicos do Departamento de Águas e Energia Elétrica do Estado de São Paulo (DAEE) e do Banco de Dados Meteorológicos para Ensino e Pesquisa (BDMEP), do Instituto Nacional de Meteorologia (INMET). Na Figura 10 é apresentada a localização espacial dos postos pluviométricos e das estações meteorológicas (compostas por séries diárias de temperatura, umidade relativa do ar, velocidade do vento e radiação solar) utilizadas nas simulações para as cinco bacias estudadas.

Caso alguma das séries diárias não esteja disponível ou ocorram falhas ao longo da série, o SWAT permite que estes dados faltantes sejam simulados a partir do gerador climático WXGEN (SHARPLEY; WILLIAMS, 1990), o qual utiliza parâmetros mensais para simular dados diários. Os parâmetros mensais requeridos para alimentação do gerador climático consistem em dados relacionados à quantificação e frequência da precipitação, temperaturas máxima e mínima, radiação solar, temperatura do ponto de orvalho e velocidade do vento.

A versão 2012 do SWAT traz em seu banco de dados uma compilação de parâmetros mensais abrangendo todo o território dos Estados Unidos. Para outras localidades, é necessário que o usuário insira manualmente os parâmetros relativos a estações localizadas nas proximidades da área em questão. Nas simulações realizadas neste estudo foram utilizados os parâmetros mensais compilados no banco de dados CFSR World Weather Database, o qual é composto de uma grade de valores abrangendo todo o globo terrestre gerada a partir de um modelo de circulação geral oceano-atmosfera. 

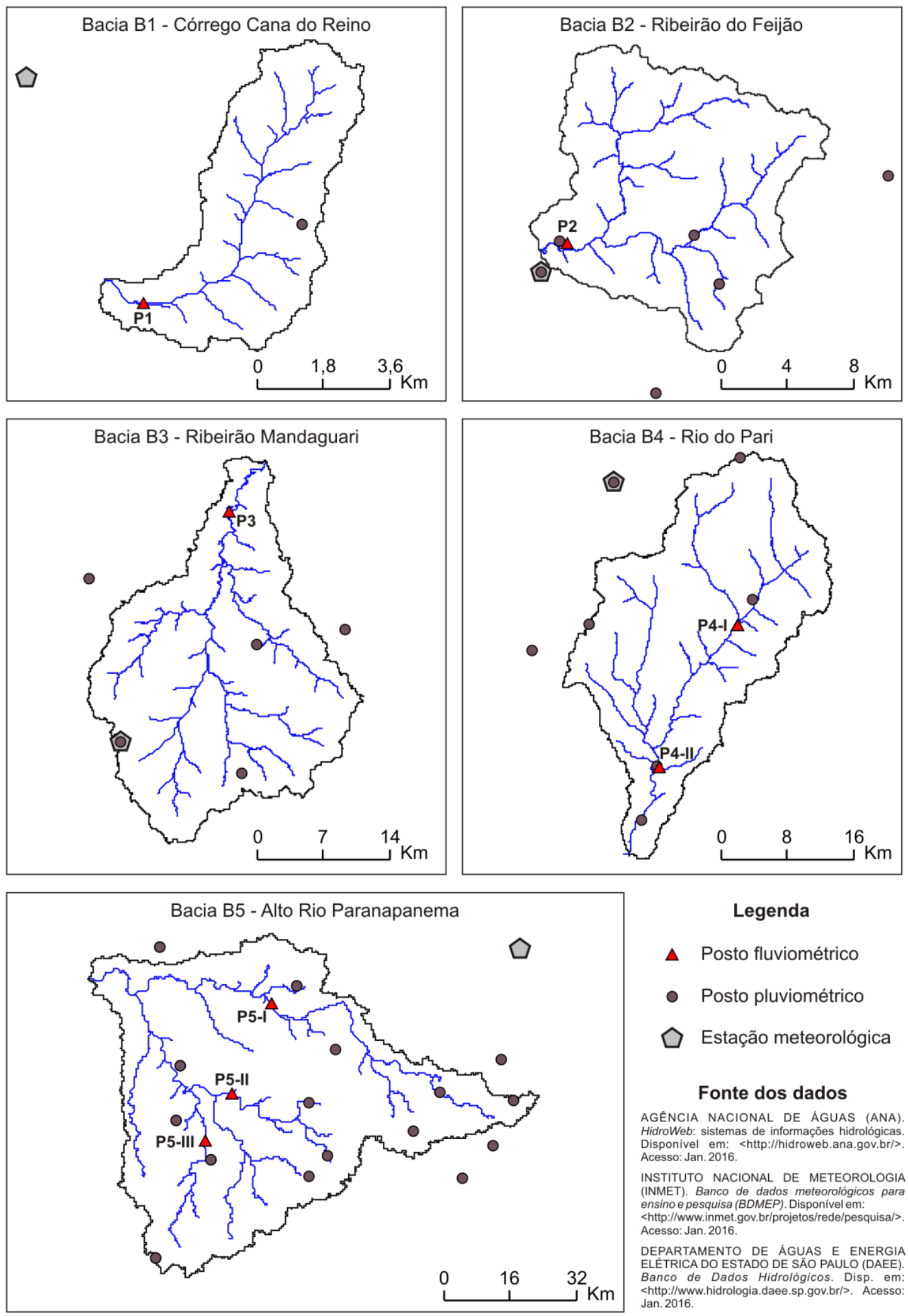

Bacia B4 - Rio do Pari

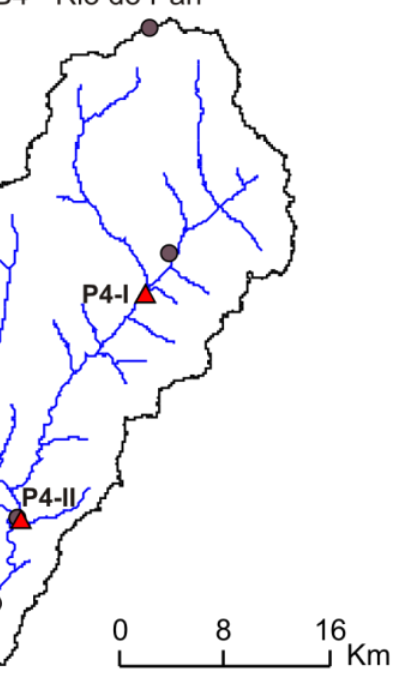

\section{Legenda}

$\Delta$ Posto fluviométrico

- Posto pluviométrico

$\triangle$ Estação meteorológica

\section{Fonte dos dados}

AGÊNCIA NACIONAL DE ÁGUAS (ANA). HišWlat sistemas de informaçoes hidrologicas. Acesso: 2016 -

INSTITUTO NACIONAL DE METEOROLOGIA (INMET). Banco de dados meteorológicos para <http://www.inmet.gov.br/projetos/rede/pesquisa/>. Acesso: Jan. 2016

DEPARTAMENTO DE ÁGUAS E ENERGIA ELÉTRICA DO ESTADO DE SĀO PAULO (DAEE). Banco de Dados Hidrologicos. Disp. em: <http://www.hidrologia.daee.sp.gov.br/>. Acesso:
Jan. 2016 .

Figura 10 - Localização dos postos fluviométricos, pluviométricos e estações meteorológicas utilizadas nas simulações. 
Em relação à definição das Unidades de Resposta Hidrológica (HRU) para as bacias, utilizou-se a opção de múltiplas HRU por sub-bacia, com o intuito de manter um maior detalhamento e evitar perda significativa de informações de entrada. Os limiares inseridos para simplificação das classes de tipo de solo, de uso da terra e de declividade foram recomendados por Winchell et al. (2013) no manual do usuário do SWAT, sendo de 10, 20 e $20 \%$, respectivamente. Desse modo, somente os tipos de solo com área superior a 10\% da sub-bacia foram combinados para formar HRUs, enquanto os tipos com área inferior a esse limiar foram substituídos por classes de maior representatividade. De modo análogo, o mesmo aplica-se para o uso da terra e a declividade, com limiares de $20 \%$ cada. Informações referentes às simulações em cada uma das cinco bacias de estudo, como o número de subbacias, a quantidade de HRUs formadas e o período de cada simulação encontram-se compiladas na Tabela 9.

Tabela 9 - Configurações gerais adotadas nas simulações para as bacias de estudo.

\begin{tabular}{ccccc}
\hline Bacia & $\begin{array}{c}\text { Número de } \\
\text { sub-bacias }\end{array}$ & $\begin{array}{c}\text { Número } \\
\text { de HRUs }\end{array}$ & $\begin{array}{c}\text { Data de início e término } \\
\text { das simulações }\end{array}$ & $\begin{array}{c}\text { Período de } \\
\text { aquecimento }\end{array}$ \\
\hline B1 & 38 & 93 & $\begin{array}{c}01 / 01 / 2002-31 / 12 / 2014 \\
(13 \text { anos })\end{array}$ & 3 anos \\
B2 & 53 & 167 & $\begin{array}{c}01 / 01 / 1980-31 / 12 / 2007 \\
(28 \text { anos })\end{array}$ & 4 anos \\
B3 & 61 & 171 & $\begin{array}{c}01 / 01 / 1995-31 / 12 / 2009 \\
(15 \text { anos })\end{array}$ & 3 anos \\
B4 & 59 & 228 & $\begin{array}{c}01 / 01 / 1994-31 / 12 / 2013 \\
(20 \text { anos })\end{array}$ & 4 anos \\
B5 & 104 & 234 & $01 / 01 / 1992-31 / 12 / 2012$ & 3 anos \\
\hline
\end{tabular}

Outro ponto determinante nas simulações é a definição do período de aquecimento do modelo por parte do usuário. Tal período, também conhecido como warm-up, é necessário devido às incertezas relacionadas às condições iniciais da simulação, principalmente no que se refere aos parâmetros relacionados ao movimento da água no solo. O warm-up adequado pode variar de acordo com o tamanho da bacia hidrográfica, cobertura do solo e com a precipitação anual. Para a maioria das aplicações, um período de dois ou três anos é geralmente ideal para permitir a simulação do ciclo hidrológico de forma operacional (ARNOLD et al., 2012a). Nas 
simulações para as bacias de estudo, foram adotados períodos de três e quatro anos, conforme exposto anteriormente na Tabela 9.

Para a realização das simulações realizadas neste trabalho, foi selecionado o Método de Penman-Monteith para o cálculo da evapotranspiração potencial e o Método da Curva Número para determinação do escoamento superficial. Já a propagação da água pelos canais da bacia foi simulada através do Método da Média Variável.

\subsection{Modificações visando à melhoria da simulação hidrológica}

Além dos procedimentos mínimos requeridos para a simulação no SWAT descritos anteriormente, foram implementadas neste estudo alterações visando o aprimoramento da simulação hidrológica, em especial de processos associados à evapotranspiração. Nesta seção são descritas as modificações realizadas nas rotinas de dormência relacionadas ao crescimento das plantas, as quais foram alteradas diretamente no código fonte do SWAT (item 4.4.1). Também foram realizadas mudanças em configurações ajustáveis do modelo, passíveis de edição pelo usuário através da interface ArcSWAT, a exemplo das operações de manejo (plantio, colheita, dentre outras) (item 4.4.2) e dos parâmetros do banco de dados de crescimento das plantas (item 4.4.3). Estes ajustes foram realizados tendo como base informações obtidas em trabalhos científicos e manuais técnicos publicados no Brasil, em especial na região sudeste.

Para fins comparativos, foram realizadas duas simulações distintas para cada uma das cinco bacias de estudo. Na primeira simulação foram executados os procedimentos descritos no item 4.3, ou seja, realizou-se a inserção de dados topográficos, pedológicos, de uso da terra e climatológicos, mantendo-se os valores padrão para os demais componentes do modelo. Tal simulação no decorrer do texto será nominada como Simulação Padrão. Na segunda simulação, além de realizados os procedimentos básicos descritos até então, foram executadas as modificações adicionais propostas nesta seção, ou seja, adaptações nas rotinas e nos parâmetros relacionados ao crescimento vegetal. No decorrer do texto, esta segunda simulação será denominada Simulação Modificada.

\subsubsection{Alteração das rotinas de dormência no código fonte do SWAT}

O SWAT pressupõe que as árvores, as culturas perenes e as culturas anuais de estação fria, quando sob condições climáticas desfavoráveis entram em estado de dormência, período 
no qual não há crescimento vegetal. O início e o término da dormência são definidos por um limiar de duração do dia, o qual, uma vez atingido durante o outono, interrompe o crescimento da planta, voltando a ocorrer apenas quando o mesmo limiar é novamente superado na primavera.

O mecanismo de dormência possui singularidades de acordo com o tipo de planta considerado pelo modelo. No início da dormência para as árvores uma fração da biomassa vegetal é convertida em resíduo e o índice de área foliar (IAF) atinge o valor mínimo permitido. O índice de área foliar mínimo na dormência é dado pelo parâmetro ALAI_MIN, definido no banco de dados de crescimento vegetal para cada tipo de cultura. Para plantas perenes um valor fixo de $10 \%$ da biomassa é convertido em resíduo e o índice de área foliar é, assim como no caso das árvores, reduzido para o valor mínimo. Já para plantas anuais de estação fria nenhuma parte da biomassa é convertida em resíduo (NEITSCH et al., 2011).

A Figura 11 apresenta graficamente a variação anual do índice de área foliar para cinco HRUs de diferentes usos da terra da bacia do Ribeirão do Feijão (Bacia B2), durante o ano de 2007. Tais resultados foram obtidos a partir da Simulação Padrão, ou seja, sem qualquer alteração das operações de manejo e dos parâmetros do banco de dados de crescimento vegetal. Nas HRUs com mata, eucalipto, pastagem e cana-de-açúcar, verifica-se um decaimento brusco do índice de área foliar ao final da primeira quinzena do mês de junho, ocasionado pelo mecanismo de dormência do modelo. O IAF é reduzido para o valor mínimo permitido, dado pelo parâmetro ALAI_MIN, o qual, por padrão, é de $0,75 \mathrm{~m}^{2} \cdot \mathrm{m}^{-2}$ para mata e zero para os demais usos. Tal redução do índice de área foliar não reflete o ciclo de desenvolvimento de plantas de ambientes tropicais e sub-tropicais, visto que a indução de dormência associada ao fotoperíodo, com a consequente queda das folhas, é característica associada a plantas de regiões frias.

Através de sua interface, o SWAT não possibilita que o usuário altere ou desative o mecanismo de dormência durante as simulações. É possível apenas a modificação de parâmetros relacionados à dormência no banco de dados de crescimento vegetal, como o parâmetro ALAI_MIN, por exemplo, que pode variar de um mínimo de 0 a um máximo de $0,99 \mathrm{~m}^{2} \cdot \mathrm{m}^{-2}$. Entretanto, tal range de valores não é adequado para representar a dinâmica de crescimento vegetal em zonas tropicais, visto que ainda induz a uma redução significativa do índice de área foliar nos meses de menor fotoperíodo. 


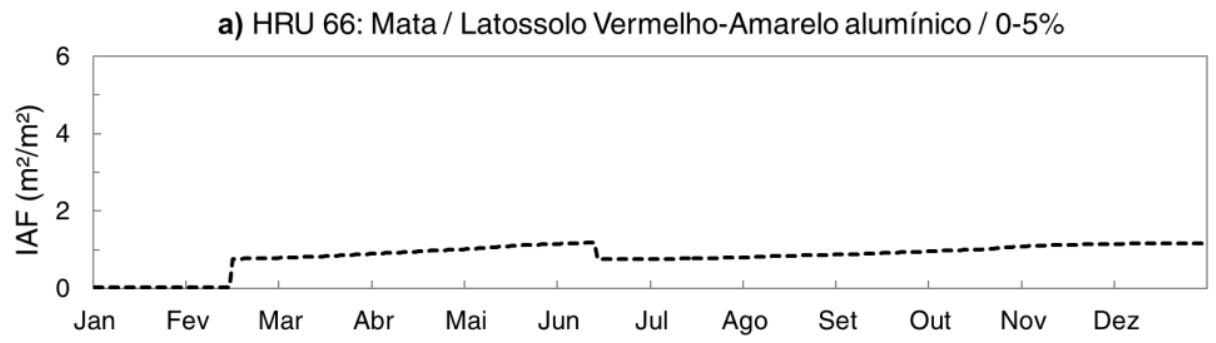

b) HRU 106: Eucalipto / Neossolo Quartzarênico órtico / 5-20\%

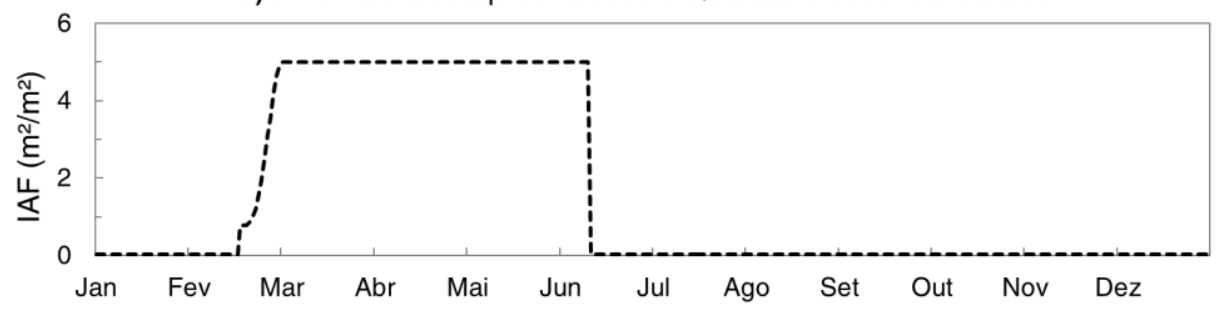

c) HRU 82: Pastagem / Latossolo Vermelho-Amarelo alumínico / 5-20\%

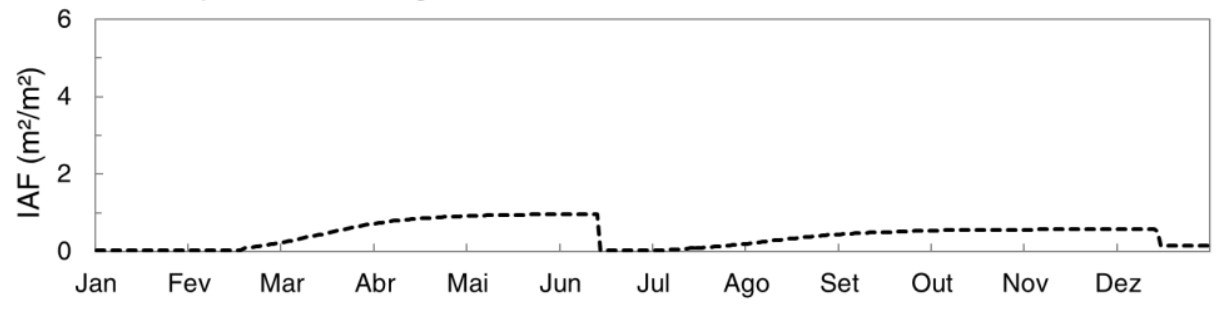

d) HRU 73: Cana-de-açúcar / Latossolo Vermelho-Amarelo alumínico / 5-20\%

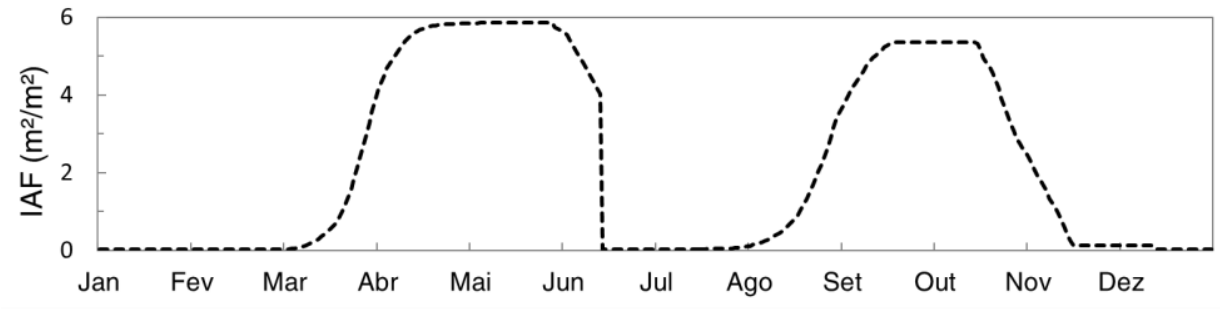

e) HRU 164: Agricultura genérica / Neossolo Quartzarênico órtico / 0-5\%

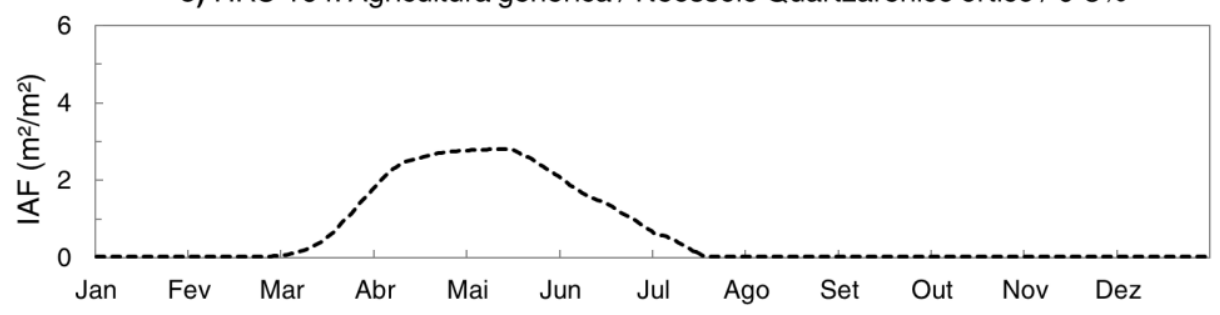

Figura 11 - Variação anual do índice de área foliar em cinco HRUs de distintos usos da terra da bacia do Ribeirão do Feijão: (a) mata; (b) reflorestamento de eucalipto; (c) pastagem; (d) cana-de-açúcar e (e) culturas agrícolas genéricas.

Visando contornar tais limitações, foi realizada a modificação das rotinas de crescimento vegetal no código fonte do modelo, com a desativação do mecanismo de dormência para as árvores, plantas perenes e plantas anuais de estação fria. Tais modificações foram realizadas a partir da versão SWAT 2012 Revisão 637 do código fonte, lançada em 18 
de maio de 2015, cujos arquivos são disponibilizados no site dos desenvolvedores do modelo. A sub-rotina modificada compreende o arquivo dormant.f, responsável pela verificação do estado de dormência dos diferentes tipos de plantas.

O código fonte do SWAT é baseado na linguagem de programação Fortran, e foi recompilado utilizando-se o compilador GFortran juntamente com a plataforma de desenvolvimento Eclipse Parallel Tools 9.0. O compilador utilizado abrange as linguagens Fortran 90 e 95, e integra o MinGW, um conjunto de ferramentas de programação voltado ao desenvolvimento de aplicações para o Windows. Após as alterações das rotinas e posterior recompilação do código modificado, foi gerado um novo executável para o SWAT, o qual foi utilizado na interface ArcSWAT para realização das demais simulações. O código fonte com a rotina dormant.f alterada encontra-se disponível no Anexo I.

\subsubsection{Alteração das operações de manejo}

O SWAT permite que o usuário defina as operações de manejo agrícola a serem executadas em cada HRU. Dentre as operações possíveis de serem programadas, incluem-se ações como plantio, colheita, simulação de pastoreio, colheita seguida de remoção da planta, lavragem, aplicação de fertilizantes, aplicação de pesticidas, irrigação, implantação de sistemas de drenagem subsuperficial, dentre outras.

Na versão 2012 do SWAT os parâmetros referentes às operações de manejo são compilados no arquivo .mgt, o qual é editado através da interface ArcSWAT. A programação das operações a serem executadas nas HRUs pode ser realizada através de frações de unidades de calor (HU), na qual as operações são executadas em função da temperatura ambiente, ou podem ser agendadas por meio de dias julianos.

O SWAT possui um conjunto de cronogramas de operações de manejo predefinidas para diferentes usos da terra, no qual os ciclos anuais das culturas são baseados no sistema de unidades de calor. Por padrão, o número total de unidades de calor necessárias para cada tipo de planta para atingir a maturidade nestes cronogramas é de 1800, valor inadequado para um grande número de culturas.

Na Simulação Padrão realizada na Bacia do Ribeirão do Feijão, realizada a partir dos cronogramas predefinidos, a operação de plantio tem seu início na segunda quinzena de fevereiro, conforme pode ser visto nos cinco usos da terra apresentados na Figura 11. Desse modo, somente há desenvolvimento vegetal e aumento do índice de área foliar após o 
acúmulo de um certo número de unidades de calor necessárias ao início do ciclo, o que acaba por tornar IAF nulo durante o mês de janeiro e parte de fevereiro.

Visando tornar a simulação mais realista e condizente com as práticas agrícolas realizadas nas bacias de estudo, foram realizadas modificações nestas operações de manejo predefinidas. Para as HRUs cobertas por mata foi habilitada a opção de desenvolvimento inicial das plantas (Initial Plant Growth), a qual indica a ocorrência de uso da terra já em crescimento na HRU no início da simulação. Através desta opção, os ciclos de manejo anuais deixam de ser executados e as condições iniciais são mantidas durante todo o período simulado. Desse modo, o código de status do uso da terra (parâmetro IGRO do modelo) foi alterado de modo a indicar a presença de uso da terra em crescimento (IGRO $=1$ ) e foi assumido um índice de área foliar inicial de valor 6 (LAI_INIT $=6 \mathrm{~m}^{2} . \mathrm{m}^{-2}$ ), mantendo-se constante durante todo o período simulado. Para as HRUs cobertas com pastagem, foi realizado o mesmo tratamento aplicado às áreas de mata. $\mathrm{O}$ código de status do uso da terra foi alterado de modo a indicar a presença de cobertura em crescimento avançado (IGRO =1) e o índice de área foliar inicial foi configurado com o valor 3 (LAI_INIT $=3 \mathrm{~m}^{2} \cdot \mathrm{m}^{-2}$ ).

Nas HRUs com cultivo de cana-de-açúcar, foi estabelecido um cronograma de operações visando representar o cultivo da cana no centro-sul do Brasil. Barbieri e Villa Nova (1977) descrevem que o plantio da referida cultura é realizado em dois sistemas distintos, conhecidos como plantio de "cana de ano" e plantio de "cana de ano e meio". O plantio feito de agosto a novembro com colheita após 11 a 14 meses (setembro a outubro do ano seguinte) é conhecido como "cana de ano". Já o plantio feito de janeiro a fevereiro com colheita após 15 a 20 meses é conhecido como "cana de ano e meio", apresentando uma produtividade maior do que o sistema de ano. No cronograma modificado, considerou-se o sistema de "cana de ano", com plantio em $1^{\circ}$ de outubro (operação Plant/begin growing season) com 2000 unidades de calor necessárias para maturação e colheita em 15 de setembro do ano seguinte (operação Harvest only). A Figura 12 ilustra a inserção destas informações na interface do ArcSWAT.

As HRUs com uso da terra denominado como culturas genéricas representam cultivos de verão, como por exemplo, feijão e soja. Na simulação visou-se representar um sistema de sucessão de culturas com o plantio de uma cultura de inverno nos meses mais frios. Desse modo, foi estipulado o plantio em $1^{\circ}$ de outubro (Plant/begin growing season), com 1200 unidades de calor para atingir a maturação, e colheita em 15 de março (Harvest and kill). A sucessão com a cultura de inverno foi simulada com um novo plantio em $1^{\circ}$ de abril 
(Plant/begin growing season), também com 1200 unidades de calor para maturação e colheita em 15 de setembro (Harvest and kill).

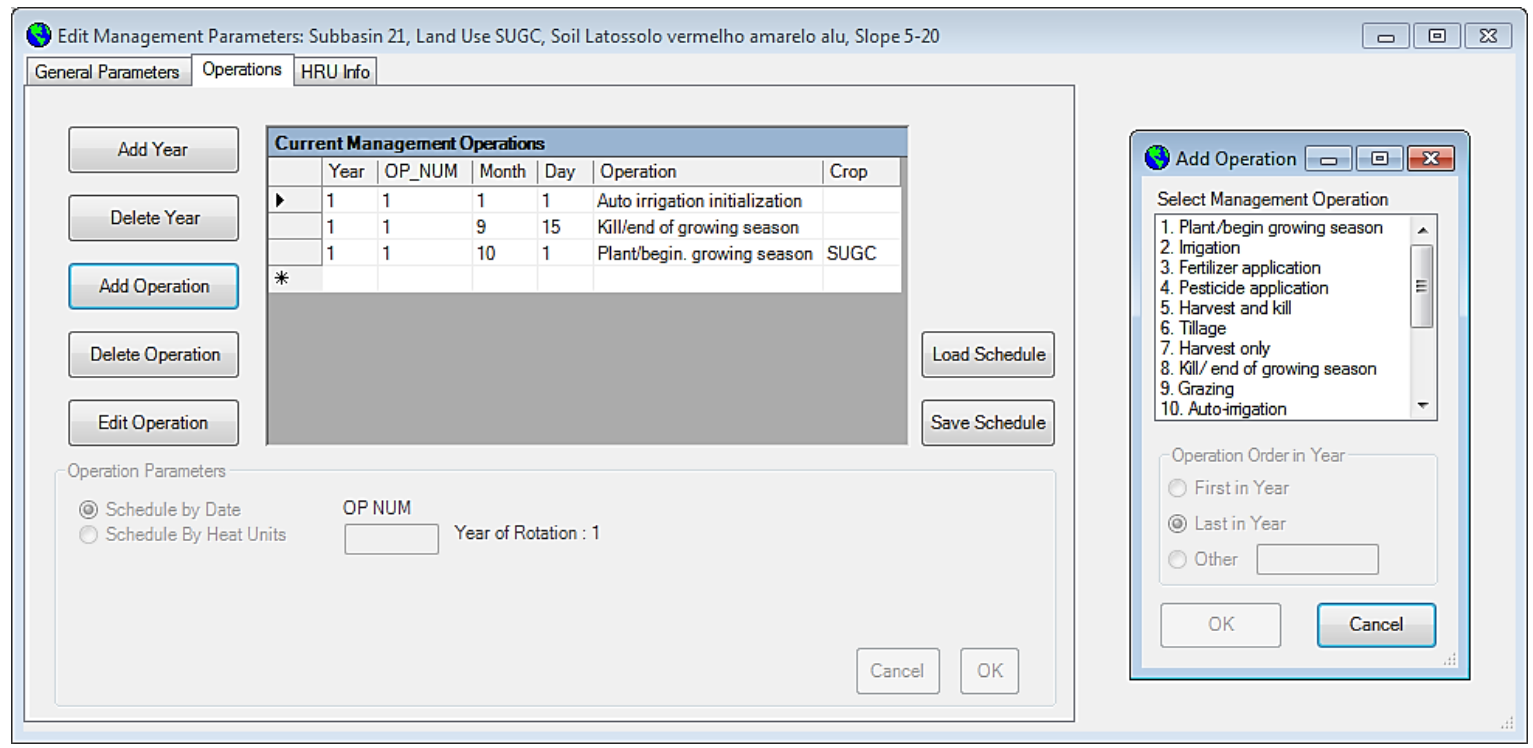

Figura 12 - Edição do cronograma de operações agrícolas para HRUs com cana-de-açúcar.

Para as HRUs com eucalipto esquematizou-se um ciclo de cultura com duração aproximada de seis anos, com plantio no início da estação chuvosa. Desse modo, foi estipulado o plantio em $1^{\circ}$ de outubro (Plant/begin growing season) com 8000 unidades de calor para atingir a maturação e colheita em 31 de agosto do sexto ano subsequente ao ano de plantio (Harvest and kill).

\subsubsection{Alteração de parâmetros do banco de dados de crescimento das plantas}

Conforme salientado anteriormente, o crescimento das plantas no SWAT é modelado através da simulação do desenvolvimento da área foliar e da conversão da luz interceptada em biomassa vegetal. Os parâmetros do banco de dados de crescimento das plantas utilizados para quantificar o desenvolvimento da área foliar são: BLAI, FRGRW1, LAIMX1, FRGRW2, LAIMX2 e DLAI, conforme pode ser observado na Figura 13.

O parâmetro BLAI representa o índice de área foliar máximo que determinada cultura pode atingir, podendo variar entre 0,5 e $10 \mathrm{~m}^{2} . \mathrm{m}^{-2}$. FRGRW1, LAIMX1, FRGRW2 e LAIMX2 são parâmetros responsáveis pela forma da curva do índice de área foliar, permitindo o ajuste da mesma em dois pontos distintos: no início do ciclo de crescimento e pouco antes de atingir o índice de área foliar máximo. Tais parâmetros foram previamente 
apresentados na seção 4.2.2 (FRGRW1 $=f r_{P H U, 1}$, LAIMX1 $=f r_{L A I, l}$, FRGRW2 $=f r_{P H U, 2}$ e LAIMX2 $\left.=f r_{L A I, 2}\right)$. O parâmetro DLAI representa a fração do ciclo de crescimento na qual o índice de área foliar começa a declinar, podendo variar de 0 a 1 . A Figura 13 ilustra graficamente a relação destes parâmetros com a curva de desenvolvimento do índice de área foliar no SWAT.

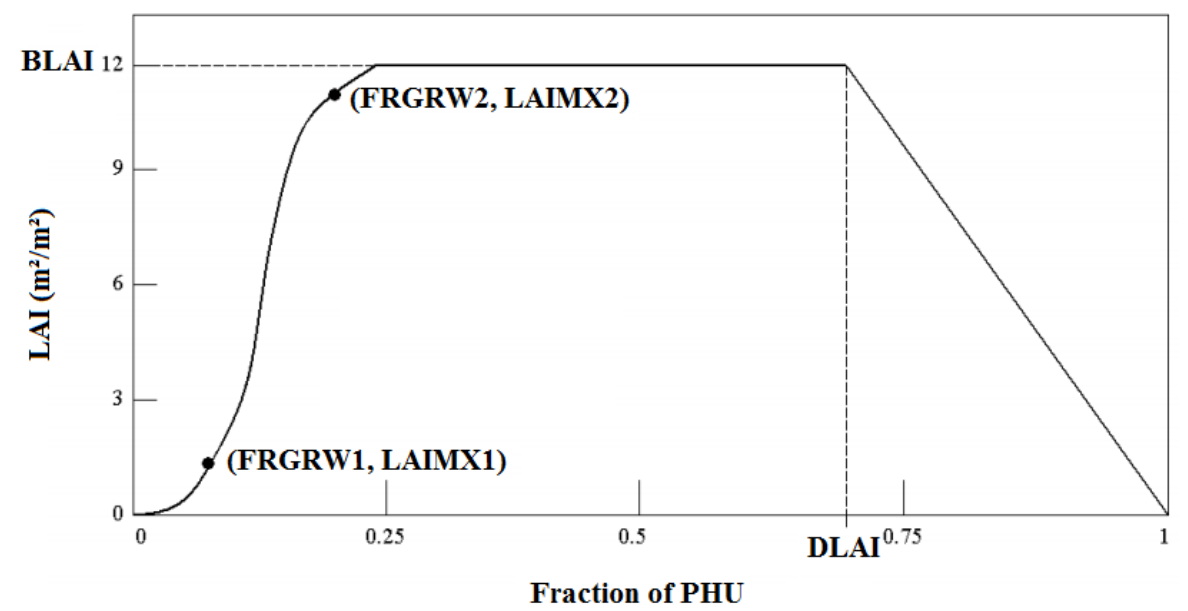

Figura 13 - Parâmetros relacionados à curva de desenvolvimento do índice de área foliar no SWAT (ARNOLD et al., 2012a).

Tais parâmetros possuem valores predeterminados no banco de dados do modelo, compilados a partir de estudos realizados nos Estados Unidos (ver ARNOLD et al., 2012a). Visando reproduzir o ciclo de desenvolvimento das culturas nas bacias de estudo, alguns destes parâmetros foram substituídos por valores provenientes de estudos nacionais. A alteração destes valores foi realizada através da interface ArcSWAT, conforme ilustrado na Figura 14.

Para a classe de uso da terra mata, foi alterado o valor do IAF máximo permitido durante a simulação (parâmetro BLAI), sendo inserido o valor $6 \mathrm{~m}^{2} \cdot \mathrm{m}^{-2}$ (ALMEIDA; SOARES, 2003). Para a cana-de-açúcar, adotou-se um IAF máximo de 4 (BLAI = $4 \mathrm{~m}^{2} \cdot \mathrm{m}^{-2}$ ) (OLIVEIRA et al., 2007). Os parâmetros de forma FRGRW1, LAIMX1, FRGRW2 e LAIMX2 foram ajustados manualmente de modo a representar um período inicial de desenvolvimento lento após o plantio de aproximadamente 2 meses, seguido de uma fase de crescimento rápido e de outra de crescimento lento, com o IAF atingindo o valor máximo cerca de 9 meses após o plantio. 


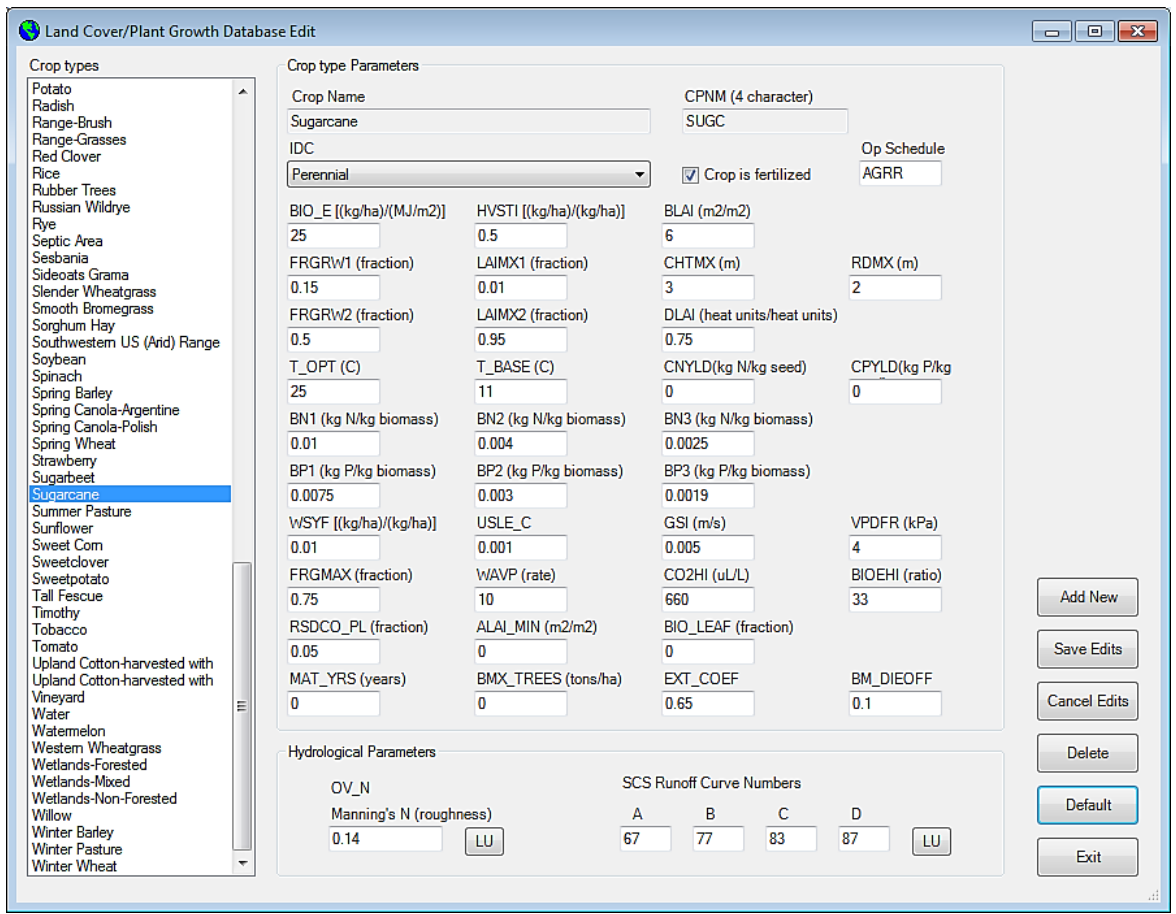

Figura 14 - Janela de edição dos parâmetros do banco de dados de crescimento das plantas.

Para as áreas de eucalipto foi inserido BLAI $=4 \mathrm{~m}^{2} \cdot \mathrm{m}^{-2}$ e os parâmetros de forma ajustados de modo a atingir o IAF máximo cerca de quatro anos após o plantio (ALMEIDA; SOARES, 2003). Para a agricultura genérica alterou-se a fração do ciclo de crescimento na qual há declínio do IAF, de modo a garantir que a colheita seja realizada antes da redução do IAF ocasionada pela senescência (DLAI $=0,8)$. A Tabela 10 sintetiza as alterações realizadas nos parâmetros, apresentando também os valores originais do modelo (default).

Tabela 10 - Alteração dos parâmetros de crescimento das plantas. Entre parênteses encontram-se os valores originais, enquanto os valores abaixo indicam o novo valor inserido.

\begin{tabular}{|c|c|c|c|c|c|c|}
\hline $\begin{array}{c}\text { Uso da } \\
\text { terra } \\
\end{array}$ & BLAI & FRGRW1 & LAIMX1 & FRGRW2 & LAIMX2 & DLAI \\
\hline Mata & $\begin{array}{l}(5) \\
6\end{array}$ & $0,05 *$ & $0,05 *$ & $0,4^{*}$ & $0,95 *$ & $0,99 *$ \\
\hline Pastagem & $\begin{array}{l}(4) \\
3\end{array}$ & $0,05 *$ & $0,05 *$ & $0,49 *$ & $0,95 *$ & $0,99 *$ \\
\hline $\begin{array}{l}\text { Cana-de- } \\
\text { açúcar }\end{array}$ & $\begin{array}{c}(6) \\
4\end{array}$ & $\begin{array}{c}(0,15) \\
0,03\end{array}$ & $0,01 *$ & $\begin{array}{l}(0,5) \\
0,55\end{array}$ & $\begin{array}{c}(0,95) \\
0,9\end{array}$ & $\begin{array}{c}(0,75) \\
0,92\end{array}$ \\
\hline Eucalipto & $\begin{array}{c}(2,5) \\
4\end{array}$ & $\begin{array}{l}(0,1) \\
0,16\end{array}$ & $\begin{array}{c}(0,15) \\
0,2\end{array}$ & $\begin{array}{c}(0,5) \\
0,6\end{array}$ & $\begin{array}{c}(0,75) \\
0,61\end{array}$ & $0,99^{*}$ \\
\hline $\begin{array}{l}\text { Agricultura } \\
\text { genérica }\end{array}$ & $3^{*}$ & $0,15^{*}$ & $0,05 *$ & $0,5^{*}$ & $0,95^{*}$ & $\begin{array}{c}(0,64) \\
0,8\end{array}$ \\
\hline
\end{tabular}

* Indica que o parâmetro original do modelo (default) foi mantido 


\subsection{Calibração e validação da vazão}

O processo de calibração, no contexto da modelagem ambiental, consiste na alteração dos parâmetros e constantes de um determinado modelo visando melhorar o ajuste entre os dados simulados e um conjunto de dados observados ou medidos. Tal processo, segundo Arnold et al. (1998), é realizado selecionando-se cuidadosamente os valores para os parâmetros de entrada (dentro das respectivas gamas de incerteza), visando melhorar a parametrização para um dado conjunto de condições locais, reduzindo, assim, a incerteza na predição.

Em relação à validação, constata-se na literatura certa divergência de concepções quanto ao que seria este processo, quanto ao que significa validar um modelo e quanto à sua diferenciação do processo de verificação. Segundo Rykiel Jr. (1996), a validação é a demonstração de que o modelo, dentro do seu domínio de aplicabilidade, possui um espectro satisfatório de precisão compatível com a aplicação prevista. Tal demonstração indica que o modelo é aceitável para uso dentro de determinado contexto. Caso o contexto ou as condições de aplicação sejam alteradas, o modelo deve ser revalidado; o que, por outro lado, não o invalida para o contexto em que foi originalmente validado.

Em termos operacionais, a validação envolve a comparação dos dados modelados com aqueles obtidos pela observação ou medidos no sistema real. A série de dados utilizada para validação deve ser independente do período utilizado na calibração, sem qualquer ajuste adicional dos parâmetros (ARNOLD et al., 1998).

Já o processo de verificação, no campo da modelagem ambiental, consiste no exame da técnica numérica computacional visando avaliar se esta realmente representa o modelo conceitual, garantindo que não há problemas numéricos inerentes à obtenção de uma solução (ASTM, 1984). Em outras palavras, é uma demonstração de que o formalismo da modelagem está correto (RYKIEL JR., 1996).

O SWAT permite a calibração e validação de uma grande diversidade de componentes, como elementos do ciclo hidrológico, vazão, sedimentos, parâmetros de qualidade da água e agroquímicos. Neste trabalho, realizou-se a calibração e validação do modelo para a vazão nas cinco bacias de estudo. As séries observadas para comparação com os resultados simulados foram obtidas nas bases de dados HidroWeb, da Agência Nacional de Águas (ANA) e no Banco de Dados Hidrológicos do Departamento de Águas e Energia Elétrica do Estado de São Paulo (DAEE). Na Figura 10 é possível visualizar a localização dos 
postos fluviométricos utilizados para calibração das cinco bacias. Nas bacias B4 - Rio do Pari e B5 - Alto Paranapanema foi realizada a calibração para múltiplos postos, sendo dois postos na bacia B4 (denominados P4-I e P4-II) e três postos na bacia B5 (denominados P5-I, P5-II e P5-III). O período de dados coletados em cada posto fluviométrico é apresentado na Tabela 11, sendo também indicada a repartição das séries entre os períodos de calibração e validação.

Tabela 11 - Repartição das séries históricas de vazão coletadas nos postos fluviométricos.

\begin{tabular}{ccc}
\hline Posto & Período utilizado para calibração & Período utilizado para validação \\
\hline P1 & $01 / 01 / 2005-31 / 12 / 2010(6$ anos $)$ & $01 / 01 / 2011-31 / 12 / 2014$ (4 anos $)$ \\
P2 & $01 / 01 / 1984-31 / 12 / 1997(14$ anos $)$ & $01 / 01 / 1998-31 / 12 / 2007(10$ anos $)$ \\
P3 & $01 / 01 / 1998-31 / 12 / 2004(7$ anos $)$ & $01 / 01 / 2005-31 / 12 / 2009(5$ anos $)$ \\
P4-I & $01 / 01 / 1998-31 / 12 / 2006(9$ anos $)$ & $01 / 01 / 2007-31 / 12 / 2013(7$ anos $)$ \\
P4-II & & \\
P5-I & & $01 / 01 / 2005-31 / 12 / 2012(8$ anos $)$ \\
P5-II & $01 / 01 / 1995-31 / 12 / 2004(10$ anos $)$ & \\
P5-III & & \\
\hline
\end{tabular}

O processo de calibração foi realizado de forma semiautomática utilizando-se o software SWAT Calibration and Uncertainty Procedures (SWAT-CUP), desenvolvido por Abbaspour et al. (2007), o qual possui cinco técnicas de otimização disponíveis, sendo elas SUFI-2, PSO, GLUE, ParaSol, e MCMC. O algoritmo utilizado foi o SUFI-2 (Sequential Uncertainty Fitting Version 2), o qual vale-se do método do hipercubo latino para definição dos parâmetros de testagem, sendo selecionados dentro de uma faixa de valores determinada pelo usuário (ROUHOLAHNEJAD et al., 2012). A função objetivo selecionada no procedimento, isto é, a métrica utilizada pelo algoritmo de otimização para determinar a qualidade da simulação hidrológica, foi o coeficiente de Nash-Sutcliffe, visto que é considerada a função mais adequada para estudos hidrológicos (MORIASI et al., 2007).

Para avaliar o ajuste entre os dados simulados e os dados observados nos postos fluviométricos foram utilizadas as seguintes estatísticas de precisão: Coeficiente de Eficiência de Nash-Sutcliffe (NSE), Percentual de Tendência (PBIAS) e o coeficiente de determinação $\left(\mathrm{R}^{2}\right)$.

O Coeficiente de Eficiência de Nash-Sutcliffe (NASH; SUTCLIFFE, 1970) é uma das estatísticas de precisão mais utilizadas para avaliação de modelos hidrológicos, sendo considerada a que melhor reflete o ajuste total de uma bacia hidrográfica (MORIASI et al., 
2007). Trata-se de um valor adimensional normalizado que determina a magnitude relativa da variância residual (ruído) em comparação com a variância dos dados observados, retratando quão bem os valores se ajustam a uma reta 1:1. Os valores do NSE podem variar no intervalo entre infinito negativo a 1 , ou seja, $(-\infty, 1]$, em que 1 representa um ajuste perfeito entre os dados observados e simulados. O NSE é calculado a partir da equação:

$$
N S E=1-\frac{\sum_{i=1}^{n}\left(Q_{o b s}-Q_{\text {sim }}\right)^{2}}{\sum_{i=1}^{n}\left(Q_{o b s}-Q_{o b s, m e d}\right)^{2}}
$$

Onde $Q_{o b s}$ é a vazão observada $\left(\mathrm{m}^{3} \cdot \mathrm{s}^{-1}\right), Q_{\text {sim }}$ é a vazão simulada pelo modelo $\left(\mathrm{m}^{3} \cdot \mathrm{s}^{-1}\right)$, $Q_{o b s, m e d}$ é a média das vazões observadas durante o período simulado $\left(\mathrm{m}^{3} \cdot \mathrm{s}^{-1}\right)$ e $n$ é o número de eventos considerados.

O Percentual de Tendência (PBIAS) diz respeito ao percentual de viés das vazões simuladas pelo modelo em relação às observadas, ou seja, é uma medida da tendência média das vazões simuladas serem maiores ou menores que as observadas (VAN LIEW et al., 2007). Quanto mais próximo de zero o valor de PBIAS, melhor será o desempenho do modelo em relação à realidade; valores positivos indicam um modelo com viés em direção à subestimação, enquanto valores negativos indicam um viés em direção à superestimação (GUPTA; SOROOSHIAN; YAPO, 1999). O PBIAS é calculado através da equação:

$$
P B I A S=\left[\frac{\sum_{i=1}^{n}\left(Q_{o b s}-Q_{s i m}\right) \cdot 100}{\sum_{i=1}^{n} Q_{o b s}}\right]
$$

Onde PBIAS é o desvio dos dados a serem avaliados, expresso na forma de porcentagem, $Q_{o b s}$ é a vazão observada $\left(\mathrm{m}^{3} \cdot \mathrm{s}^{-1}\right)$ e $Q_{\text {sim }}$ é a vazão simulada $\left(\mathrm{m}^{3} \cdot \mathrm{s}^{-1}\right)$.

O coeficiente de determinação $\left(\mathrm{R}^{2}\right)$ representa o nível de colinearidade entre os valores observados e simulados. $\mathrm{O}$ valor de $\mathrm{R}^{2}$ é sempre um número positivo entre 0 e 1 , sendo que, quanto maior for o $\mathrm{R}^{2}$ melhor será o poder de explicação da reta de regressão (LAPPONI, 2005). Este coeficiente é calculado pela equação: 


$$
R^{2}=\frac{\left[\sum_{i=1}^{n}\left(Q_{o b s}-Q_{o b s, \text { med }}\right)\left(Q_{\text {sim }}-Q_{\text {sim, med }}\right)\right]^{2}}{\sum_{i=1}^{n}\left(Q_{o b s}-Q_{o b s, \text { med }}\right)^{2} \sum_{i=1}^{n}\left(Q_{\text {sim }}-Q_{\text {sim }, \text { med }}\right)^{2}}
$$

Onde $Q_{o b s}$ é a vazão observada $\left(\mathrm{m}^{3} \cdot \mathrm{s}^{-1}\right), Q_{\text {sim }}$ é a vazão simulada pelo modelo $\left(\mathrm{m}^{3} \cdot \mathrm{s}^{-1}\right)$, $Q_{o b s, m e d}$ é a média das vazões observadas durante o período simulado $\left(\mathrm{m}^{3} . \mathrm{s}^{-1}\right), Q_{\text {sim,med }}$ é a média das vazões simuladas $\left(\mathrm{m}^{3} \cdot \mathrm{s}^{-1}\right)$ e $n$ é o número de eventos considerados.

Não existe um padrão formalmente estabelecido para avaliação do desempenho das estatísticas obtidas nas simulações com o SWAT. Uma das classificações mais recorrentes e frequentemente adotadas na literatura é a proposta por Moriasi et al. (2007), na qual, após avaliarem diversos métodos estatísticos para verificar o desempenho dos modelos de simulação para bacias hidrográficas, adotaram os intervalos apresentados na Tabela 12. Tal classificação foi utilizada neste trabalho para avaliar o ajuste entre os dados de vazão simulados e observados nas bacias simuladas.

Tabela 12 - Classificação do desempenho para o NSE e PBIAS segundo Moriasi et al. (2007).

\begin{tabular}{lcc}
\hline Classificação do desempenho & NSE & PBIAS (\%) \\
\hline Muito bom & $0,75<\mathrm{NSE} \leq 1,00$ & PBIAS $< \pm 10$ \\
Bom & $0,65<\mathrm{NSE} \leq 0,75$ & $\pm 10<$ PBIAS $< \pm 15$ \\
Satisfatório & $0,50<\mathrm{NSE} \leq 0,65$ & $\pm 15<$ PBIAS $< \pm 25$ \\
Insatisfatório & $\mathrm{NSE} \leq 0,50$ & PBIAS $> \pm 25$ \\
\hline
\end{tabular}

\subsection{Métodos empíricos de cálculo da evapotranspiração}

A medição direta da evapotranspiração por meio de lisímetros geralmente é trabalhosa e onerosa, requerendo muitos cuidados quanto à irrigação e à manutenção e manejo da cobertura vegetal do solo. Em vista disso, foram utilizados métodos empíricos e semiempíricos para estimar os totais evapotranspirados nas bacias de estudo, os quais baseiam-se em dados meteorológicos de fácil obtenção.

Conforme aponta Sediyama (1996), os métodos empíricos geralmente têm a exatidão de suas estimativas limitada pela dependência de poucas variáveis, gerando resultados pouco 
precisos quando aplicados a curtos períodos de tempo. Entretanto, para períodos maiores, a exemplo das escalas mensal e anual, tais métodos apresentam resultados satisfatórios. Desse modo, os valores de evapotranspiração simulados pelo SWAT para cada uma das cinco bacias foram comparados com estimativas de evapotranspiração obtidas através de métodos empíricos, visando avaliar a capacidade do modelo em simular a evapotranspiração em escala anual.

O critério para seleção dos métodos de estimativa da evapotranspiração potencial depende de uma série de fatores, como a disponibilidade de dados meteorológicos, a escala de tempo requerida e as condições climáticas para as quais o método foi desenvolvido. Foram selecionados cinco métodos para aplicação nas bacias de estudo, sendo eles: PenmanMonteith FAO-56 (ALLEN et al., 1998), Thornthwaite (THORNTHWAITE, 1948), Camargo (CAMARGO, 1971), Radiação Solar (DOORENBOS; PRUITT, 1977) e Blaney-Criddle (BLANEY; CRIDDLE, 1950).

Os dados meteorológicos necessários para aplicação destes métodos foram os mesmos utilizados nas simulações com o SWAT, os quais foram anteriormente apresentados na seção 4.3.4. Um maior detalhamento acerca de cada um dos métodos é apresentado a seguir.

\section{Método de Penman-Monteith FAO-56}

A FAO, em seu boletim de número 56 (ALLEN et al. 1998), apresenta uma atualização do método de Penman-Monteith onde a equação original é simplificada considerando-se alguns de seus parâmetros como constantes, visando descrever uma vegetação hipotética de referência. Tal cultura de referência hipotética é retratada como uma superfície gramada com altura de $0,12 \mathrm{~m}$, uma resistência de superfície fixa de $70{\mathrm{~s} . \mathrm{m}^{-1} \mathrm{e}}^{-1}$ albedo de 0,23 . A equação modificada passa a ser dada por:

$$
E_{O}=\frac{0,408 \Delta \cdot\left(H_{n e t}-G\right)+\gamma \frac{900}{T_{a v}+273} U_{2}\left(e^{o}-e\right)}{\Delta+\gamma\left(1+0,34 \cdot U_{2}\right)}
$$

Onde $E_{o}$ é a evapotranspiração de referência $\left(\mathrm{mm}^{-1} \mathrm{~d}^{-1}\right), \Delta$ é o ângulo da curva de pressão de vapor de saturação $\left(\mathrm{kPa} .{ }^{\circ} \mathrm{C}^{-1}\right), \mathrm{H}_{n e t}$ é a radiação líquida diária $\left(\mathrm{MJ} \cdot \mathrm{m}^{-2} \cdot \mathrm{d}^{-1}\right), G$ é a densidade do fluxo de calor para o solo $\left(\mathrm{MJ}_{\mathrm{m}} \mathrm{m}^{-2} \cdot \mathrm{d}^{-1}\right), \gamma$ é a constante psicrométrica $\left(\mathrm{kPa} .{ }^{\circ} \mathrm{C}^{-1}\right)$, $T_{a v}$ é a temperatura média do ar $\left({ }^{\circ} \mathrm{C}\right), U_{2}$ é a velocidade média do vento a $2 \mathrm{~m}$ acima da 
superfície do solo, $e^{o}$ é a pressão de vapor de saturação $(\mathrm{kPa})$ e $e$ é a pressão de vapor atual $(\mathrm{kPa})$. Os fatores necessários para aplicação da equação foram apresentados na seção 4.2.1.

O método Penman-Monteith FAO-56 tem apresentado níveis de precisão que o tornam mundialmente aceito, sendo considerado como metodologia padrão para obtenção dos valores diários de evapotranspiração de referência (HUNSAKER et al., 2003).

\section{Método de Thornthwaite}

Proposto por Thornthwaite (1948) tal método permite calcular a evapotranspiração em intervalo de tempo mensal, sendo requeridos apenas dados de temperatura média do ar e de duração do dia. O método foi desenvolvido tanto para regiões áridas quanto regiões úmidas e foi testado em inúmeros estudos realizados em várias partes do mundo, comprovando sua precisão e eficácia. A evapotranspiração potencial $\left(\mathrm{mm}\right.$. mês $\left.{ }^{-1}\right)$ pelo método de Thornthwaite é dada pela equação:

$$
E_{O}=F_{C} \cdot 16 \cdot\left(10 \cdot \frac{T_{m, a v}}{I}\right)^{a_{t}}
$$

Em que $I$ é um índice de eficiência de temperatura anual calculado com base na temperatura média mensal $\left(T_{m, a v}\right)$, sendo obtido através do somatório de 12 valores mensais conforme a equação:

$$
I=\sum_{i=1}^{12}\left(\frac{T_{m, a v}}{5}\right)^{1,514}
$$

O coeficiente $a_{t}$ da equação 4.53 é obtido por meio de uma função cúbica do índice $I$, sendo dado por:

$$
a_{t}=6,75 \times 10^{-7} \cdot I^{3}-7,71 \times 10^{-5} \cdot I^{2}+0,01791 \cdot I+0,492
$$

A equação de Thornthwaite considera um mês típico com 30 dias e insolação solar diária de 12 horas. Como o número de horas de luz por dia muda com a latitude e alguns 
meses possuem 28 e 31 dias, torna-se necessário aplicar um fator de correção $F c$ à fórmula. Tal fator $F c$ é dado por:

$$
F_{C}=\frac{h}{12} \cdot \frac{n}{30}
$$

Em que $h$ é a média mensal do número de horas de luz solar na latitude considerada e $n$ é a quantidade de dias do mês.

\section{Método de Camargo}

Camargo (1971), baseado em resultados obtidos pelo método de Thornthwaite, propôs uma nova metodologia, permitindo a simplificação dos cálculos com eficiência semelhante. Tal método baseia-se em dados de temperatura média do ar e radiação solar extraterrestre, sendo esta última variável calculada a partir da latitude do local ou obtida a partir de tabelas. A formulação do método de Camargo é dada por:

$$
E_{o}=K \cdot H_{0} \cdot T_{a v} \cdot N D
$$

Onde $E_{o}$ é a evapotranspiração potencial $\left(\mathrm{mm}^{\mathrm{dia}}{ }^{-1}\right), H_{0}$ é a radiação solar extraterrestre $\left(\mathrm{mm} . \mathrm{d}^{-1}\right)$, obtida por meio da equação $4.7, T_{a v}$ é a temperatura média diária $\left({ }^{\circ} \mathrm{C}\right)$, $N D$ é o número de dias do período e $K$ é o fator de ajuste que varia com a temperatura média anual do local, definido de acordo com as os intervalos definidos na Tabela 13.

Tabela 13 - Valor de K em relação à temperatura média anual (CAMARGO; CAMARGO, 2000).

\begin{tabular}{cc}
\hline Temperatura média anual $\left({ }^{\circ} \mathbf{C}\right)$ & Valor de $\mathbf{K}$ \\
\hline$<23,5$ & 0,0100 \\
23,6 a 24,5 & 0,0105 \\
24,6 a 25,5 & 0,0110 \\
25,6 a 26,5 & 0,0115 \\
26,6 a 27,5 & 0,0120 \\
$>27,5$ & 0,0130 \\
\hline
\end{tabular}




\section{Método da Radiação Solar}

Desenvolvido por Doorenbos e Pruitt (1977) para as condições de umidade da Holanda, tal método baseia-se originalmente apenas na radiação solar para o cálculo da evapotranspiração potencial. Através da introdução de um coeficiente de correção da variação do vento e umidade, sua validação foi estendida para uma extensa faixa de condições climatológicas. O método da Radiação Solar é expresso pela seguinte equação (PEREIRA; VILLA NOVA; SEDIYAMA, 1997):

$$
E_{o}=c o+c l \cdot\left(W \cdot H_{d a y}\right)
$$

Em que $E_{o}$ é a evapotranspiração potencial $\left(\mathrm{mm} \operatorname{dia}^{-1}\right), H_{\text {day }}$ é a radiação solar global $\left(\mathrm{mm}^{-1} \mathrm{~d}^{-1}\right), W$ é o fator de ponderação que representa a fração de $H_{\text {day }}$ utilizada na evapotranspiração para diferentes valores de temperatura e altitude e $c o$ e $c l$ são coeficientes de correção. Visando evitar a utilização de nomogramas, Frevert, Hill e Braaten (1983) fixaram o valor do coeficiente $c o$ em $-0,3 \mathrm{~mm} \cdot \mathrm{d}^{-1}$ e propuseram a seguinte equação para $\mathrm{cl}$ :

$$
\begin{aligned}
& c l=1,0656-0,12795 \cdot 10^{-2} \cdot R H+0,044953 \cdot U_{2}-0,2033 \cdot 10^{-3} \cdot R H \cdot U_{2}- \\
& -0,31508 \cdot 10^{-4} \cdot R H^{2}-0,11026 \cdot 10^{-2} \cdot U_{2}^{2}
\end{aligned}
$$

Em que $R H$ é a umidade relativa diária (\%) e $U_{2}$ é a velocidade média do vento medida a $2 \mathrm{~m}$ de altura $\left(\mathrm{m} \cdot \mathrm{s}^{-1}\right)$.

Por fim, o fator $W$ da equação 4.58 é obtido por:

$$
W=\frac{\Delta}{(\Delta+\gamma)}
$$

Em que $\Delta$ é a inclinação da curva de pressão de saturação e vapor e temperatura do ar $\left(\mathrm{kPa} .{ }^{\circ} \mathrm{C}^{-1}\right)$, obtida pela equação 4.16 , e $\gamma$ é a constante psicrométrica $\left(\mathrm{kPa} .{ }^{\circ} \mathrm{C}^{-1}\right)$, obtida anteriormente pela equação 4.19 . 


\section{Método de Blaney-Criddle}

O método de Blaney e Criddle (1950) foi originalmente desenvolvido para o semiárido dos Estados Unidos, sendo posteriormente adaptado para várias condições climáticas com a inserção de um fator de correção, ficando conhecido como método Blaney-Criddle FAO-24. A evapotranspiração através deste método é estimada a partir da temperatura média diária, umidade relativa, velocidade do vento e insolação diária. A equação do método de Blaney-Criddle modificado apresentada no boletim FAO-24 (DOOREMBOS; PRUITT, 1977) é dada por:

$$
E_{o}=a_{b c}+b_{b c} \cdot\left[p \cdot\left(0,46 \cdot T_{a v}+8,13\right)\right]
$$

Em que $E_{o}$ é a evapotranspiração potencial $\left(\mathrm{mm}^{\mathrm{d}} \mathrm{dia}^{-1}\right), a_{b c}$ e $b_{b c}$ são coeficientes de ajuste da equação para demais localidades, $p$ é a porcentagem diária média de luz em função da latitude e época do ano, obtido na Tabela 14 , e $T_{a v}$ é a temperatura média diária $\left({ }^{\circ} \mathrm{C}\right)$.

Os coeficientes $a_{b c}$ e $b_{b c}$ da equação 4.61 são dados por:

$$
\begin{aligned}
& a_{b c}=0,0043 \cdot R H-\frac{n}{N}-1,41 \\
& b_{b c}=0,81917-0,0040922 \cdot R H+1,0705 \cdot \frac{n}{N}+0,065694 \cdot U_{2}- \\
& -0,0059684 \cdot R H \cdot \frac{n}{N}-0,0005967 \cdot R H \cdot U_{2}
\end{aligned}
$$

Em que $R H$ é a umidade relativa (\%), $U_{2}$ é a velocidade média do vento a 2 metros de altura $\left(\mathrm{m} . \mathrm{s}^{-1}\right), n$ é o número de horas reais de insolação (h) e $N$ é o fotoperíodo (h). $\mathrm{O}$ fotoperíodo diário pode ser calculado através da declinação solar $\delta$, dada pela equação 4.5 , e pela latitude $\varphi$ da localidade (rad), conforme:

$$
N=\left(\frac{24}{\pi}\right) \arccos [-\tan (\varphi) \cdot \tan (\delta)]
$$


Tabela 14 - Fator de correção $p$ em função da latitude e época do ano (DOOREMBOS;

PRUITT, 1977).

\begin{tabular}{lcccccc}
\hline \multirow{1}{*}{\multicolumn{1}{c}{ Mês }} & \multicolumn{7}{c}{ Latitude Sul } \\
\cline { 2 - 7 } & $\mathbf{2 0}^{\circ}$ & $\mathbf{2 1}^{\circ}$ & $\mathbf{2 2}^{\circ}$ & $\mathbf{2 3}^{\circ}$ & $\mathbf{2 4}^{\circ}$ & $\mathbf{2 5}^{\circ}$ \\
\hline Janeiro & 0,300 & 0,302 & 0,304 & 0,306 & 0,308 & 0,310 \\
Fevereiro & 0,290 & 0,290 & 0,290 & 0,290 & 0,290 & 0,290 \\
Março & 0,280 & 0,280 & 0,280 & 0,280 & 0,280 & 0,280 \\
Abril & 0,260 & 0,260 & 0,260 & 0,260 & 0,260 & 0,260 \\
Maio & 0,250 & 0,250 & 0,250 & 0,250 & 0,250 & 0,250 \\
Junho & 0,250 & 0,248 & 0,246 & 0,244 & 0,242 & 0,240 \\
Julho & 0,250 & 0,248 & 0,246 & 0,244 & 0,242 & 0,240 \\
Agosto & 0,260 & 0,260 & 0,260 & 0,260 & 0,260 & 0,260 \\
Setembro & 0,270 & 0,270 & 0,270 & 0,270 & 0,270 & 0,270 \\
Outubro & 0,280 & 0,282 & 0,284 & 0,286 & 0,288 & 0,290 \\
Novembro & 0,290 & 0,292 & 0,294 & 0,296 & 0,298 & 0,300 \\
Dezembro & 0,300 & 0,302 & 0,304 & 0,306 & 0,308 & 0,310 \\
\hline
\end{tabular}

\section{Estimativa da evapotranspiração real}

Para a determinação da evapotranspiração real foi utilizado o método simplificado de ajuste da evaporação potencial por meio da incorporação do coeficiente de cultura $K_{c}$, sendo a evapotranspiração real dada pela equação:

$$
E_{a}=K_{c} \cdot E_{o}
$$

Onde $E_{a}$ é a evapotranspiração real da cultura $(\mathrm{mm}), K_{c}$ é o coeficiente de cultura (adimensional) e $E_{o}$ é a evapotranspiração potencial $(\mathrm{mm})$. O coeficiente $K_{c}$ representa a relação entre a demanda evapotranspiratória da cultura e do ambiente, sendo determinado experimentalmente e variando de acordo com o estágio fenológico da planta e com as práticas agronômicas adotadas. Desse modo, o valor de $K_{c}$ aumenta desde um valor mínimo na germinação até um valor máximo, quando a cultura atinge seu pleno desenvolvimento, e decresce a partir do início da maturação.

Neste trabalho foram utilizados para as culturas os valores de $K_{c}$ recomendados pela FAO publicados no boletim de número 56 (ALLEN et al. 1998). Para fins de simplificação de 
cálculo foi adotado um único $K_{c}$ médio para todo o ciclo de cultivo, obtido a partir da média ponderada entre a duração das etapas de desenvolvimento da planta (em dias) e seus respectivos $K_{c}$. Os valores dos $K_{c}$ médios resultantes deste procedimento são apresentados na Tabela 15.

Tabela 15 - Coeficientes de cultura utilizados na determinação da evapotranspiração real.

\begin{tabular}{lc}
\hline Cultura & $\mathbf{K}_{\mathbf{c}}$ médio \\
\hline Mata & 1,00 \\
Pastagem & 0,90 \\
Cana-de-açúcar & 1,02 \\
Eucalipto & 1,00 \\
Milho & 0,85 \\
Seringueira & 0,98 \\
Agricultura genérica & 0,85 \\
\hline
\end{tabular}

A estimativa da evapotranspiração real para as cinco bacias foi realizada conforme Barreto, Wendland e Marcuzzo (2009) a partir da equação:

$$
E_{a-b s n}=\sum_{i=1}^{n}\left(K_{c i} \cdot E_{o} \cdot A r_{i}\right)
$$

Em que $E_{a-b s n}$ é a evapotranspiração real estimada para a bacia $(\mathrm{mm}), K_{c i}$ é o coeficiente de cultura médio para a cultura $i$ em todo o período de cultivo (adimensional), $E_{o}$ é a evapotranspiração potencial e $A r_{i}$ é a área relativa da cultura $i$ em relação à área total da bacia. 


\section{RESULTADOS E DISCUSSÃO}

Nesta seção são apresentados os resultados das simulações através da comparação entre os valores obtidos na Simulação Padrão e os obtidos na Simulação Modificada, de forma a avaliar como as modificações nas rotinas de modelagem e as edições dos parâmetros referentes ao crescimento vegetal e operações de manejo alteraram as respostas do modelo.

Nesse sentido, inicialmente serão discutidos os resultados relativos à modificação do índice de área foliar (IAF) e da evapotranspiração no nível das HRUs (item 5.1), passando-se em seguida à análise dos componentes do balanço hídrico anual na bacia hidrográfica como um todo (item 5.2). Em seguida, serão analisadas as respostas das simulações de vazão nos postos fluviométricos das bacias, avaliando-se o ajuste entre os dados observados e simulados através de estatísticas de precisão (item 5.3). Na etapa final, é descrito o processo de calibração e validação da vazão para a simulação de melhor desempenho, de modo a melhorar o ajuste entre as respostas simuladas e os dados observados (item 5.4).

\subsection{Evapotranspiração e índice de área foliar nas HRUs}

A maior parte dos fenômenos e processos simulados pelo SWAT são inicialmente determinados em nível de HRU, sendo posteriormente agregados para o nível de sub-bacia e de bacia hidrográfica. Nesse sentido, é de fundamental importância que os resultados simulados pelo modelo sejam inicialmente analisados no nível de HRU, visto que esta é a unidade fundamental adotada na simulação.

Para fins de análise, foram selecionadas cinco das 167 HRUs estabelecidas na simulação para a Bacia do Ribeirão do Feijão. As HRUs selecionadas já foram anteriormente apresentadas na seção 4.4.1 (Figura 11) e representam usos da terra distintos, sendo eles: mata $\left(\mathrm{HRU} \mathrm{n}^{\circ}\right.$ 66), pastagem (HRU $\mathrm{n}^{\circ} 82$ ), plantio de eucalipto (HRU $\left.\mathrm{n}^{\circ} 106\right)$, plantio de cana-deaçúcar (HRU $\mathrm{n}^{\circ} 73$ ) e áreas de agricultura genérica (HRU $\left.\mathrm{n}^{\circ} 164\right)$. O período selecionado para análise das HRUs foi o ano de 2007, o qual apresentou uma precipitação anual de 1441 $\mathrm{mm}$.

Na Figura 15 é exibida a variação diária do índice de área foliar e da evapotranspiração potencial (ETp) e real (ETr) ao longo do ano de 2007 para a HRU de número 66 da Bacia do Ribeirão do Feijão, a qual é coberta por mata. Para fins comparativos, 
de forma a evidenciar como as alterações propostas no SWAT influenciaram os resultados simulados, são apresentados graficamente os resultados tanto para a Simulação Padrão quanto para a Simulação Modificada.
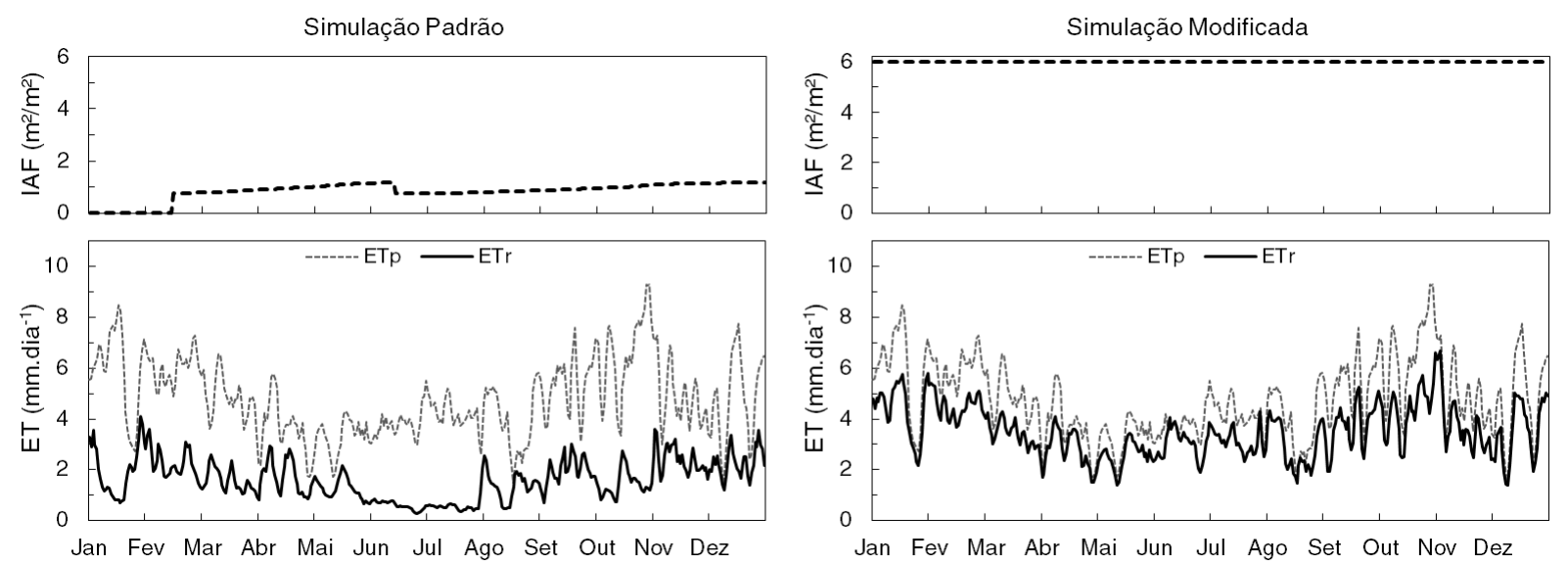

Figura 15 - Gráfico comparativo do IAF e da evapotranspiração entre a Simulação Padrão (à esquerda) e Modificada (à direita) em HRU coberta por mata.

As modificações propostas para as HRUs de mata definiram a presença de vegetação em desenvolvimento avançado no início da simulação ao invés de iniciar o ciclo de crescimento a partir da germinação, bem como ajustaram um IAF fixo de valor $6 \mathrm{~m}^{2} \cdot \mathrm{m}^{-2}$ para todo o período simulado. Apesar de diversos trabalhos apontarem que o IAF de áreas florestadas sofre certa variação sazonal conforme o regime hídrico (SANCHES et al., 2008), tal configuração adotada neste trabalho apresenta maior similaridade ao IAF tipicamente observado em ecossistemas florestais do que as configurações padrão já definidas no SWAT.

Verificou-se que ao ajustar um IAF fixo de valor $6 \mathrm{~m}^{2} \cdot \mathrm{m}^{-2}$ para as áreas de mata houve um aumento significativo da evapotranspiração real diária na HRU em todo o período, a qual aproximou-se dos valores estimados para a evapotranspiração potencial. Esta última, conforme pode ser observado na Figura 15, manteve-se inalterada em ambas as simulações, visto que expressa o potencial de evapotranspiração para as condições meteorológicas vigentes, sendo, portanto, um parâmetro fundamentalmente meteorológico.

Na Simulação Padrão verifica-se que os valores de ETr situaram-se na faixa de 0,27 a 4,10 mm.dia ${ }^{-1}$, apresentando uma média de $1,62 \mathrm{~mm} \cdot \operatorname{dia}^{-1}$ para o período. Na Simulação Modificada a ETr concentrou-se na faixa de 1,37 a $6,65 \mathrm{~mm} \cdot \mathrm{dia}^{-1}$, e a média para todo o período passou a 3,51 mm.dia ${ }^{-1}$. Em termos de totais anuais, a evapotranspiração real foi de 604 mm.ano ${ }^{-1}$ na Simulação Padrão, enquanto na Modificada aumentou para 1107 mm.ano ${ }^{-1}$. 
Este valor anual aproxima-se dos resultados experimentais obtidos por Cicco (2009) para evapotranspiração real em uma micro-bacia de Mata Atlântica situada na região metropolitana de São Paulo, onde, através do método do balanço hídrico, obteve-se uma ETr de 1006 mm.ano ${ }^{-1}$ durante o ano 2000. No mesmo trabalho, o autor também calculou para a mesma área uma ETr de 1000 mm.ano ${ }^{-1}$ através do método do balanço de cloreto.

De maneira análoga, o ajuste do IAF fixo de valor $3 \mathrm{~m}^{2} \cdot \mathrm{m}^{-2}$ para a pastagem também resultou em aumento significativo da evapotranspiração real diária, conforme observado nos resultados para a HRU de número 82 da Bacia do Ribeirão do Feijão, expostos na Figura 16.
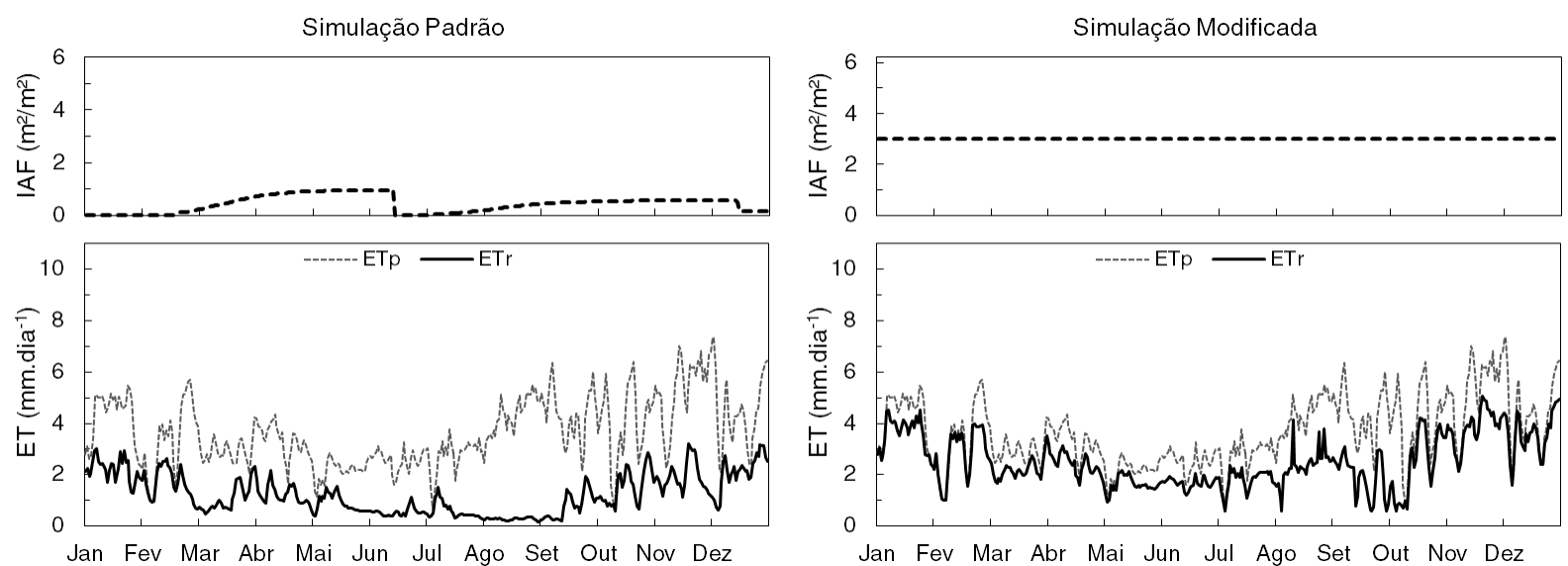

Figura 16 - Gráfico comparativo do IAF e da evapotranspiração entre a Simulação Padrão (à esquerda) e Modificada (à direita) em HRU coberta por pastagem.

A análise da Figura 16 evidencia que na Simulação Padrão os valores de ETr situaramse na faixa de 0,18 a 3,21 mm.dia ${ }^{-1}$, com média de 1,24 mm.dia ${ }^{-1}$. Já na Simulação Modificada o intervalo de valores foi de 0,59 a $5,06 \mathrm{~mm} \cdot \mathrm{dia}^{-1}$, com média de 2,53 mm.dia ${ }^{-1}$ para o período. Em termos anuais, a ETr na HRU passou de $462 \mathrm{~mm}$. ano ${ }^{-1}$ na Simulação Padrão para 807 mm.ano ${ }^{-1}$ na Simulação Modificada, com os maiores valores diários concentrando-se durante a estação chuvosa (outubro a março). Para fins de comparação, no trabalho de Oliveira et al. (2014) foi obtida uma evapotranspiração de $720 \mathrm{~mm} \cdot$ ano $^{-1}$ em área de pastagem no Bioma Cerrado através do método da covariância dos vórtices turbulentos, enquanto no trabalho de Nobrega et al. (2015) estimou-se um valor de $532 \mathrm{~mm} \cdot$ ano $^{-1}$ através do método do balanço hídrico.

Nas HRUs cobertas por reflorestamento de eucalipto foi estabelecido um ciclo de cultivo de aproximadamente seis anos, com a planta atingindo o IAF máximo entre quatro e 
cinco anos de idade. Na Figura 17 é apresentada a variação do IAF e da evapotranspiração para a HRU de número 106 da Bacia do Ribeirão do Feijão.
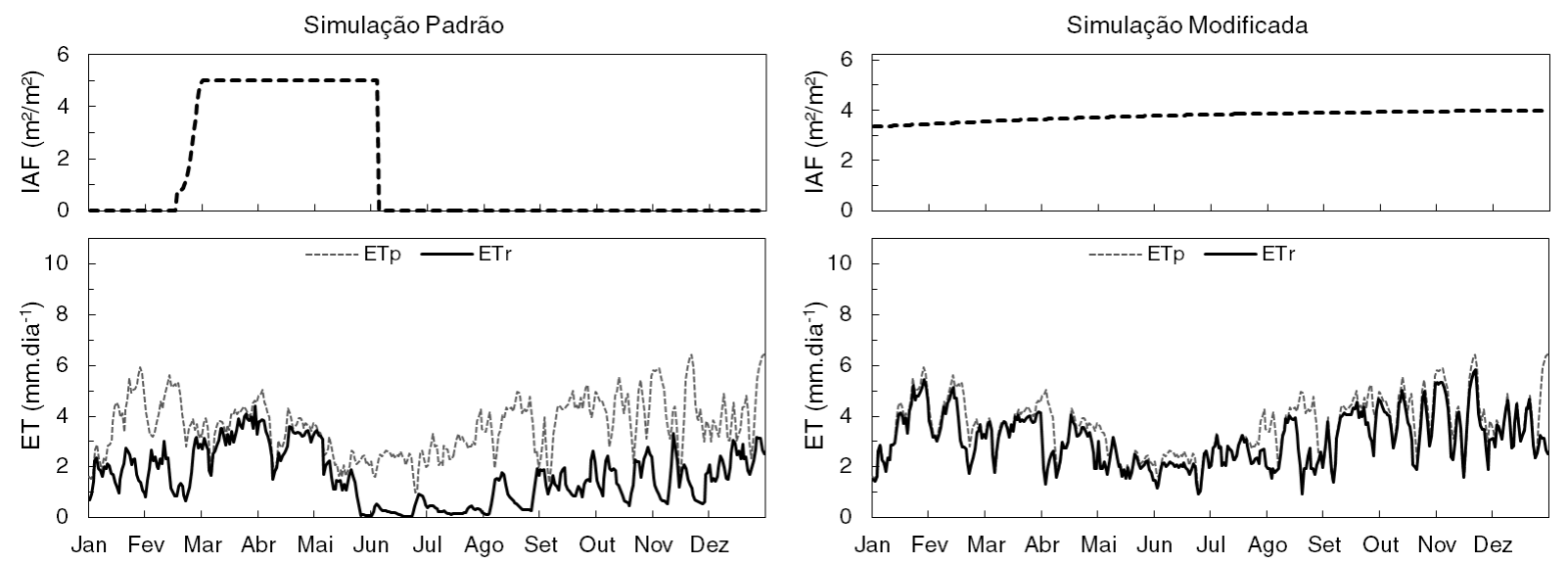

Figura 17 - Gráfico comparativo do IAF e da evapotranspiração entre a Simulação Padrão (à esquerda) e Modificada (à direita) em HRU coberta por plantio de eucalipto.

O ano analisado (2007) corresponde ao quinto ano após o plantio do eucalipto, sendo possível verificar a cultura atingindo o IAF máximo nos últimos meses da Simulação Modificada. Verifica-se que a modificação do IAF permitiu que os valores de evapotranspiração chegassem próximos aos valores máximos estimados para a evapotranspiração potencial na HRU.

$\mathrm{Na}$ análise dos valores diários de evapotranspiração verifica-se que na Simulação Padrão foram obtidos valores entre 0,06 e 4,40 mm.dia ${ }^{-1}$, sendo resumidos por uma média de 1,62 mm.dia ${ }^{-1}$ para o período. Com as modificações realizadas, os totais diários situaram-se na faixa de 0,92 a 5,82 mm.dia ${ }^{-1}$, com média de 3,09 mm.dia ${ }^{-1}$. Em termos de totais anuais, a evapotranspiração real na HRU passou de $598 \mathrm{~mm}^{\mathrm{ano}} \mathrm{o}^{-1}$ para $1050 \mathrm{~mm}$.ano ${ }^{-1}$ na Simulação Modificada. Tal valor é compatível com as estimativas experimentais obtidas por Câmara e Lima (1999) para uma área de eucalipto localizada na região de Botucatu - SP, onde foi estimada uma evapotranspiração anual de $1061 \mathrm{~mm}^{-a n o}{ }^{-1}$ através do método do balanço hídrico. Valor semelhante também foi descrito por Cabral et al. (2010) para uma área com eucalipto localizada na região de Ribeirão Preto - SP, onde foi medida uma evapotranspiração de 1124 mm. ano ${ }^{-1}$ através do método da correlação de turbilhões.

Na Figura 18 são apresentados os resultados para a HRU de número 73 do Ribeirão do Feijão, a qual possui como uso da terra o plantio de cana-de-açúcar. Para tal cultura, as 
modificações realizadas atuaram principalmente visando à alteração da sazonalidade do IAF ao longo do ano, de modo a refletir os ciclos de plantio realizados na bacia.
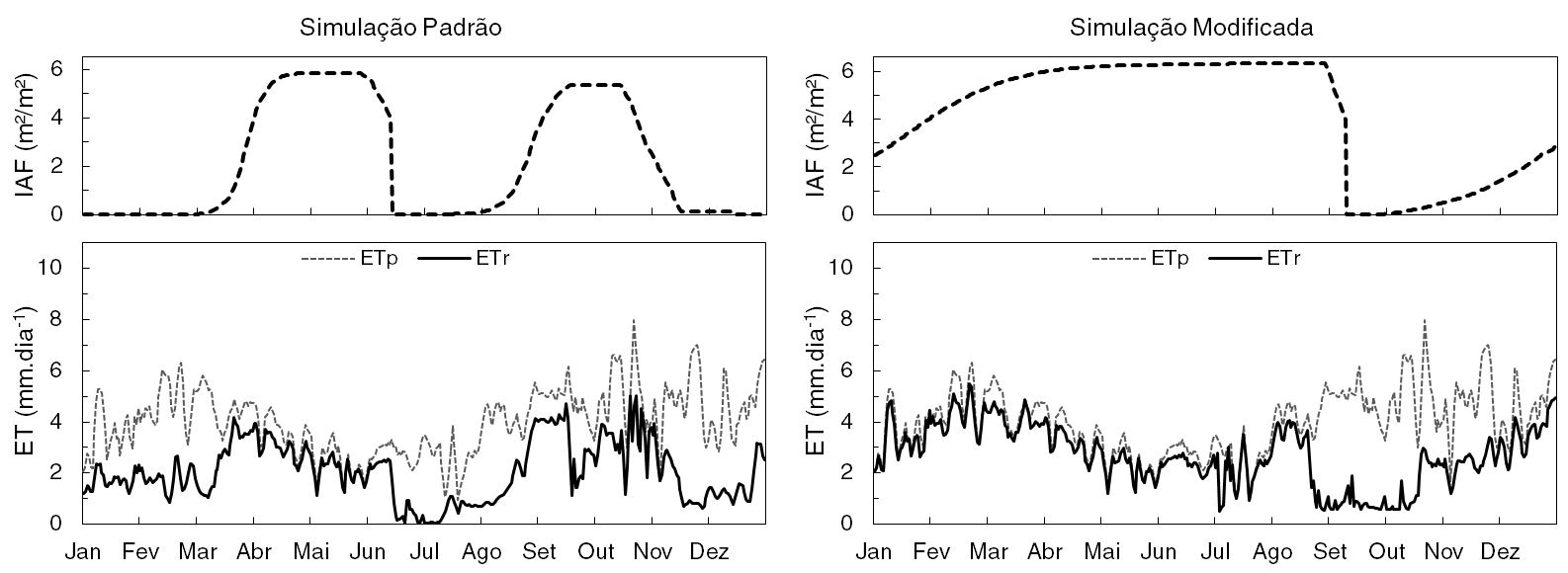

Figura 18 - Gráfico comparativo do IAF e da evapotranspiração entre a Simulação Padrão (à esquerda) e Modificada (à direita) em HRU coberta por cana-de-açúcar.

Na Simulação Padrão verifica-se a ocorrência do plantio no final de fevereiro e colheita no meio de novembro, com um período de redução do IAF em junho e julho devido à dormência. Em tal situação, nota-se a ocorrência de altos valores de evapotranspiração apenas nos meses nos quais o IAF é elevado. Já na Simulação Modificada o plantio foi configurado para ocorrer em outubro, com o IAF atingindo o valor máximo após cerca de oito meses e colheita após aproximadamente um ano. Nesta configuração, o período entre a colheita e o novo ciclo de desenvolvimento (setembro - outubro) apresentou baixa evapotranspiração devido à ausência de área foliar na planta, situação na qual há o predomínio apenas da componente evaporação do solo. Com o crescimento da planta e consequente aumento do IAF, a componente transpiração passa a ser significativa, elevando os valores de evapotranspiração nos meses seguintes.

Na Simulação Padrão para a HRU com cana-de-açúcar os valores diários de evapotranspiração real compreenderam o intervalo de 0,04 a 5,03 mm.dia ${ }^{-1}$, com o valor médio de 2,06 mm.dia ${ }^{-1}$ para o período. Na Simulação Modificada o intervalo de valores passou a ser entre 0,52 e $5,48 \mathrm{~mm} \cdot \mathrm{dia}^{-1}$, com média de 2,69 mm.dia ${ }^{-1}$. A evapotranspiração anual foi de $748 \mathrm{~mm}$ na Simulação Padrão, passando a $964 \mathrm{~mm}$.ano ${ }^{-1}$ após a implementação das alterações sugeridas neste trabalho. Tal valor aproxima-se dos $959 \mathrm{~mm}^{\text {ano }}{ }^{-1}$ obtidos no trabalho de Nassif (2015), em experimento realizado em uma área de plantio de cana-de- 
açúcar localizada em Piracicaba - SP, na qual a evapotranspiração foi medida através do método do balanço de energia - Razão de Bowen.

Finalmente, na Figura 19 são apresentados os resultados de IAF e evapotranspiração para a HRU de número 164, onde o uso da terra é definido pela classe culturas genéricas.
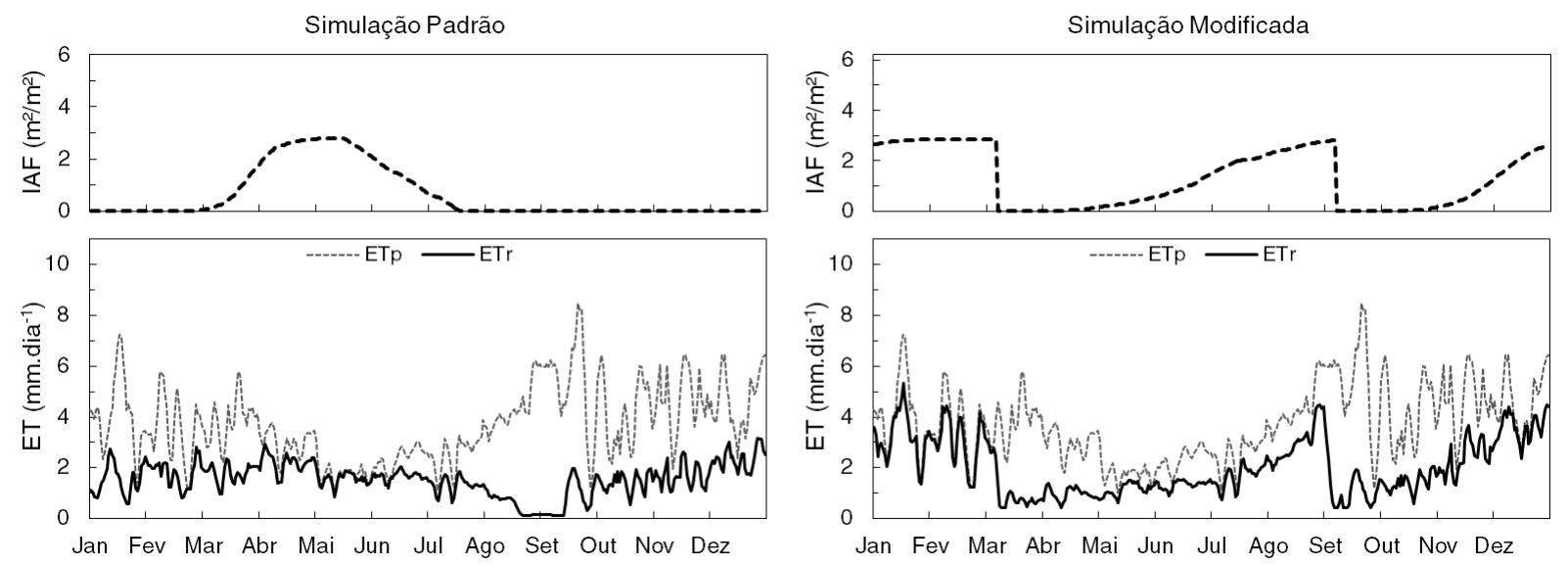

Figura 19 - Gráfico comparativo do IAF e da evapotranspiração entre a Simulação Padrão (à esquerda) e Modificada (à direita) em HRU coberta por cultura agrícola genérica.

Na configuração padrão o modelo simulou um único cultivo com plantio no final de fevereiro, o que ocasionou um IAF nulo na maior parte do ano, resultando em baixos valores de evapotranspiração. Já na Simulação Modificada, foi estabelecida a ocorrência de dois cultivos anuais, de modo a representar um sistema de sucessão de culturas de verão e de inverno, com plantios realizados em outubro e abril. Sob tal configuração, a evapotranspiração apresentou maiores valores nos períodos de IAF elevado e menores valores nos períodos entre cultivos (março - abril e setembro - outubro), nos quais há predomínio da evaporação do solo em detrimento da transpiração.

Em termos de totais diários, a ETr apresentou valores entre 0,10 e 3,17 mm.dia ${ }^{-1}$, com média de 1,55 mm.dia ${ }^{-1}$, conforme pode ser observado na Figura 19. Na Simulação Modificada a faixa de valores obtidos variou entre 0,42 a 5,34 mm.dia ${ }^{-1}$, com média de 2,01 mm.dia ${ }^{-1}$ para o ano em questão. Já em termos de totais anuais, a evapotranspiração passou de 577 mm.ano ${ }^{-1}$ na Simulação Padrão para 786 mm.ano ${ }^{-1}$ na Simulação Modificada.

Os resultados observados através da análise temporal das HRUs individuais permitem evidenciar a forte associação entre os valores de evapotranspiração real e o índice de área foliar. Conforme descrito por Neitsch et al. (2011), o SWAT calcula a evapotranspiração real através de três componentes independentes, sendo eles: a transpiração da planta, a evaporação 
da precipitação interceptada pelo dossel e a evaporação da água no solo. A quantidade de água perdida por transpiração é calculada como uma função linear do IAF, enquanto a evaporação das águas interceptadas no dossel é diretamente proporcional à sua capacidade de armazenamento, a qual por sua vez é função do volume foliar. Desse modo, a simulação inadequada do IAF para os usos da terra analisados resultou em subestimativa da evapotranspiração nas HRUs, visto que, nesta situação, o único processo contabilizado corretamente em seu cálculo foi a evaporação da água no solo.

Nesse sentido, as modificações propostas resultaram no ajuste do IAF para os usos da terra nas bacias, tanto em termos de magnitude quanto em sazonalidade, ocasionando o aumento dos processos de transpiração e evaporação da água do dossel das plantas e, consequentemente, levando a uma estimativa mais realista da evapotranspiração. Visando investigar como cada uma destas alterações influenciaram os resultados obtidos, é apresentado na Figura 20 um exercício de simulação no qual cada uma das alterações são testadas individualmente. $\mathrm{O}$ procedimento para tal análise consistiu na desativação, uma a uma, das modificações propostas nos itens 4.4.1, 4.4.2 e 4.4.3, retornando às configurações padrão do modelo, porém mantendo-se as demais alterações. Os testes foram realizados a partir da HRU de número 73 da bacia do Ribeirão do Feijão, discutida anteriormente na Figura 18, cujo uso compreende plantio de cana-de-açúcar.

A curva do IAF apresentada na Figura 20 (a) foi obtida a partir da edição dos cronogramas de manejo e da modificação dos parâmetros do banco de dados de crescimento das plantas, sendo desativada a modificação realizada nas rotinas de dormência do código fonte do modelo (item 4.4.1). Verifica-se que ao realizar a simulação sem a devida modificação no código fonte ocorre a indução de dormência no mês de junho, com o decaimento do IAF e redução da evapotranspiração real na HRU, sendo iniciado um novo ciclo de cultivo a partir do mês de agosto. Conforme já salientado anteriormente, a separação de ciclos de cultivo com base na dormência vegetal é fortemente associada a regiões temperadas, sendo muitas vezes inadequada para muitas espécies das regiões tropicais. Portanto, constata-se que somente alterações nas configurações editáveis do modelo (isto é, alterações nos cronogramas de manejo e nos parâmetros de crescimento vegetal) não foram suficientes para obter uma simulação adequada do desenvolvimento da cultura. 

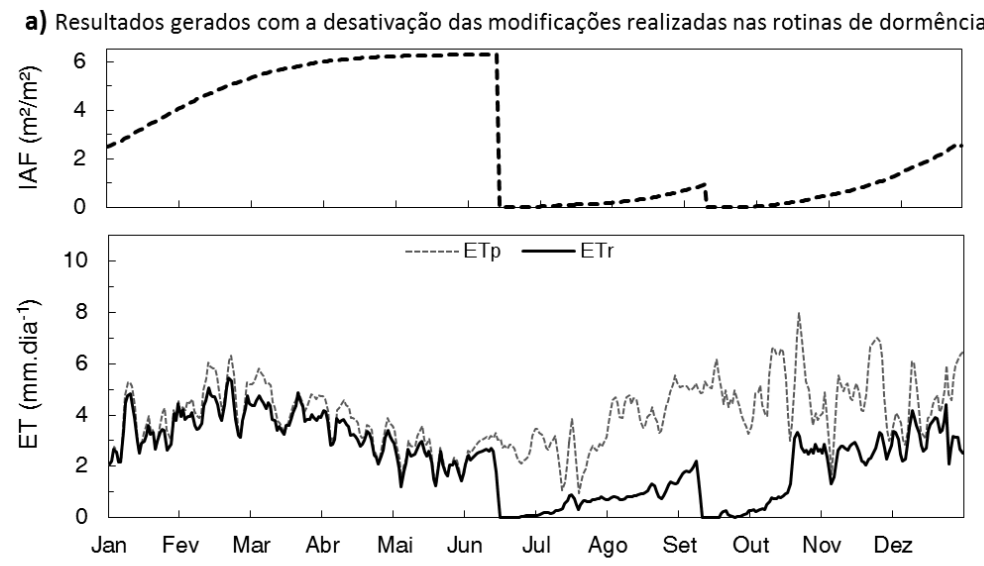

b) Resultados gerados mantendo-se os cronogramas de manejo originais do modelo
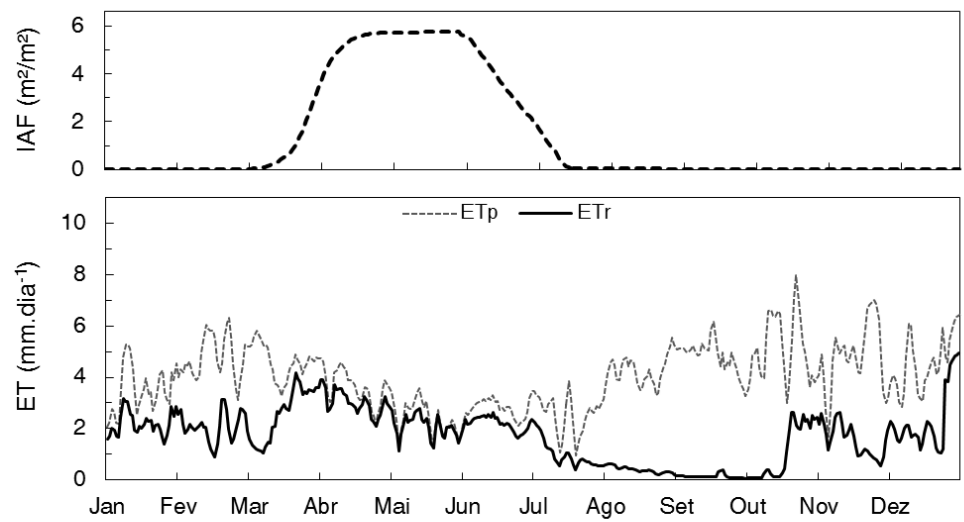

c) Resultados gerados mantendo-se os parâmetros de crescimento vegetal originais do modelo

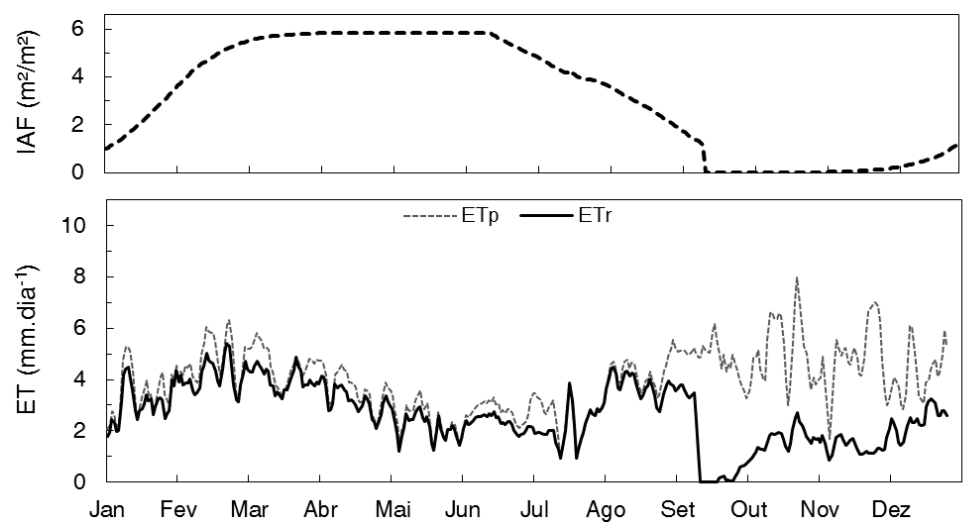

Figura 20 - Resposta do índice de área foliar (IAF) e da evapotranspiração (ET) na HRU com cana-de-açúcar: (a) sem a alteração da rotina de dormência vegetal; (b) sem a alteração dos cronogramas de manejo; e (c) sem a alteração dos parâmetros de crescimento vegetal.

Os resultados apresentados na Figura 20 (b) foram gerados a partir de uma simulação na qual as alterações nas rotinas de dormência e as modificações nos parâmetros de crescimento vegetal foram mantidas, sendo desativados os cronogramas de manejo estabelecidos na seção 4.4.2. O cronograma padrão do modelo baseado em unidades de calor mostrou-se inadequado para simulação do ciclo de cultivo da cana-de-açúcar, visto que 
resultou em IAF nulo na maior parte do ano, bem como gerou valores diários de $\mathrm{ETr}$ inferiores aos observados anteriormente na Figura 18.

Já na Figura 20 (c) é retratada uma simulação onde mantiveram-se as alterações nas rotinas de dormência e nos cronogramas de manejo, porém foram desativadas as alterações realizadas nos parâmetros do banco de dados de crescimento das plantas, descritas na seção 4.4.3. Sob esta configuração, verifica-se que a forma da curva do IAF sofreu modificações significativas mesmo mantendo-se o cronograma de manejo estipulado, com a planta atingindo o IAF máximo rapidamente e entrando no período de senescência prematuramente, ocasionando em uma redução gradativa do IAF durante boa parte do ciclo vegetativo. Tal constatação sugere fortemente a necessidade de revisão e adaptação dos parâmetros do banco de dados de crescimento vegetal conforme as peculiaridades da região na qual será realizada a simulação.

\subsection{Análise dos componentes do balanço hídrico}

Independentemente do tipo de estudo realizado com o SWAT, uma representação adequada dos componentes do balanço hídrico é fundamental para obtenção de resultados satisfatórios na modelagem. Nesse sentido, são apresentadas nesta seção as estimativas dos componentes do balanço hídrico para as bacias de estudo frente às modificações realizadas no modelo, buscando-se comparar tais resultados com estudos experimentais realizados em bacias semelhantes.

Na Figura 21 são apresentadas as estimativas anuais para os principais componentes do balanço hídrico nas cinco bacias simuladas, tanto para a Simulação Padrão quanto para a Simulação Modificada. Também são exibidas nos gráficos as variações percentuais entre os valores obtidos nas duas simulações para cada um dos componentes simulados. Tais estimativas correspondem à média anual referente ao período simulado em cada bacia, excluindo-se o período de aquecimento do modelo, conforme apresentado anteriormente na Tabela 9.

A análise dos componentes hidrológicos permite inferir que a precipitação anual nas bacias variou na faixa de $1293 \mathrm{~mm}$ (Bacia B3) a $1444 \mathrm{~mm}$ (Bacia B5). Os totais precipitados mantiveram-se iguais nas duas simulações realizadas, visto que não houve modificação dos dados meteorológicos de entrada entre as mesmas. 

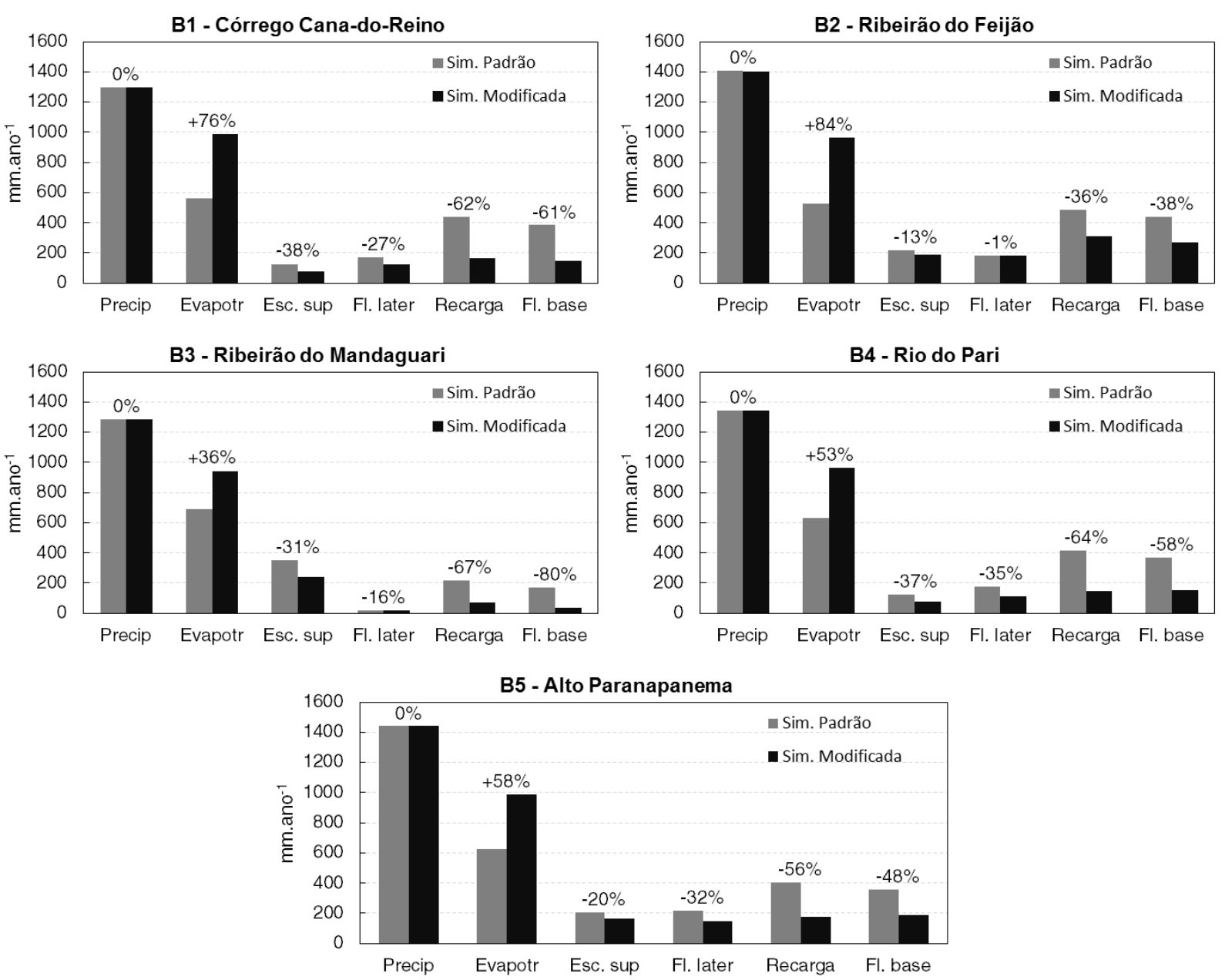

Figura 21 - Comparação entre os principais componentes do balanço hídrico anual nas Simulações Padrão e Modificada (precipitação, evapotranspiração real, escoamento superficial, fluxo lateral, recarga para o aquífero raso e fluxo de base).

A evapotranspiração real apresentou valores na faixa entre 523 e $692 \mathrm{~mm}$ na Simulação Padrão, enquanto na Simulação Modificada os totais anuais situaram-se entre 940 e $985 \mathrm{~mm}$. Em todas as cinco bacias foram observados aumentos significativos entre as simulações: na bacia B1 - Córrego Cana-do-Reino a evapotranspiração passou de $558 \mathrm{~mm}$ na Simulação Padrão para 987 mm na Simulação Modificada, o que corresponde a um aumento de 76\%. Na bacia B2 - Ribeirão do Feijão a alteração foi de $523 \mathrm{~mm}$ para $964 \mathrm{~mm}$, um aumento de $84 \%$, o maior dentre todas as bacias. Na bacia B3 - Ribeirão do Mandaguari, a evapotranspiração passou de 692 a $940 \mathrm{~mm}$, que corresponde a um aumento de 36\%, sendo a menor variação observada. Na bacia B4 - Rio do Pari, variou de $630 \mathrm{~mm}$ para $966 \mathrm{~mm}$, totalizando aumento de 53\%. Por fim, na bacia B5 - Alto Paranapanema, a evapotranspiração passou de 623 a $985 \mathrm{~mm}$, representando uma variação de 58\%. Em termos percentuais 
médios, ou seja, considerando-se a variação das cinco bacias, a evapotranspiração apresentou um aumento de $61 \%$ nas simulações realizadas.

Ao analisar-se a relação evapotranspiração/precipitação, ou seja, a porcentagem do total precipitado que foi convertido em evapotranspiração em cada bacia, verifica-se que na Simulação Padrão os percentuais para as bacias B1, B2, B3, B4 e B5 foram de 43\%, 37\%, $53 \%, 46 \%$ e $43 \%$, respectivamente. Na Simulação Modificada a porcentagem de precipitação convertida em evapotranspiração passou a 76\%,68\%,73\%,71\% e 68\%, respectivamente, valores que se aproximam das relações obtidas em estudos de campo.

Verifica-se que os totais anuais de evapotranspiração obtidos através da Simulação Modificada são coerentes com os totais anuais determinados por métodos empíricos e semiempíricos, estimados com base em dados meteorológicos. Na Figura 22 são apresentadas as estimativas de evapotranspiração real obtidas pelos métodos de Penman-Monteith FAO-56, Thornthwaite, Camargo, Radiação Solar e Blaney-Criddle para cada uma das cinco bacias analisadas.

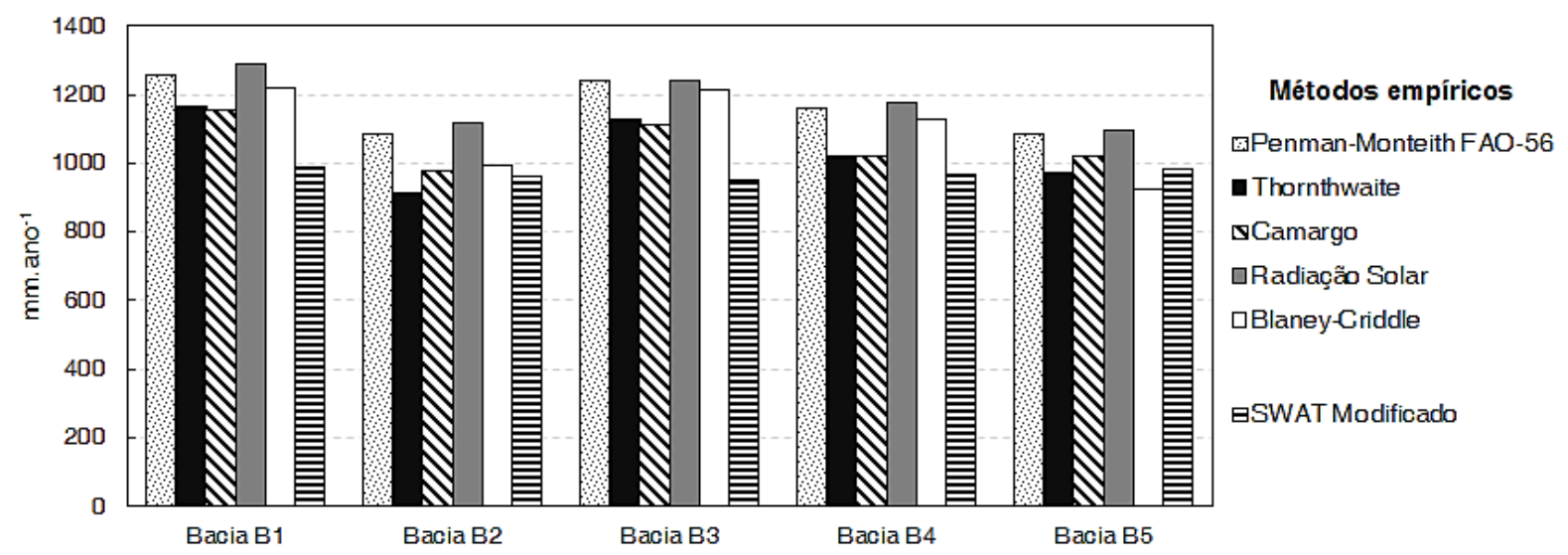

Figura 22 - Estimativa da evapotranspiração real anual para as cinco bacias obtidas através de métodos empíricos.

Na bacia B1 - Córrego Cana-do-Reino foram obtidas as maiores estimativas de evapotranspiração anual dentre as bacias, variando de $1155 \mathrm{~mm}$ pelo Método de Camargo até $1287 \mathrm{~mm}$ através do Método da Radiação Solar. A faixa de valores obtida empiricamente é levemente superior ao valor observado na Simulação Modificada do SWAT, que foi de 987 mm. Já na bacia B2 - Ribeirão do Feijão foram obtidos os menores valores empíricos dentre as cinco bacias, os quais situaram-se na faixa de $914 \mathrm{~mm}$, através do Método de 
Thornthwaite, até 1118 mm, pelo Método da Radiação Solar. Tal faixa de valores compreende o valor estimado na simulação com o SWAT, que foi de $964 \mathrm{~mm}$.

Para a bacia B3 - Ribeirão do Mandaguari, o menor valor foi obtido com o Método de Camargo, sendo este de $1114 \mathrm{~mm}$, enquanto o maior valor foi observado com o Método de Penman-Monteith FAO-56, sendo de $1241 \mathrm{~mm}$. O valor simulado pelo SWAT para tal bacia foi de $940 \mathrm{~mm}$ anuais, inferior a todos os valores estimados pelos métodos empíricos. $\mathrm{Na}$ bacia B4 - Rio do Pari foi obtido o mínimo de $1021 \mathrm{~mm}$ com o Método de Thornthwaite e máximo de $1176 \mathrm{~mm}$ pelo Método da Radiação Solar, todos superiores ao valor de $966 \mathrm{~mm}$ simulado pelo SWAT modificado. Por fim, na bacia B5 - Alto Paranapanema, os métodos empíricos apontaram valores entre $922 \mathrm{~mm}$, pelo Método de Blaney-Criddle, e $1097 \mathrm{~mm}$, pelo Método da Radiação Solar. A simulação com o SWAT estimou o valor de 985 mm, o qual encontra-se dentro da faixa de valores estimada empiricamente.

Desse modo, verifica-se que nas bacias B2 e B5 os valores de transpiração simulados pela versão modificada do SWAT situaram-se dentro da faixa de valores estimados pelos métodos empíricos para as respectivas áreas. Já as bacias B1, B3 e B4 apresentaram valores simulados um pouco inferiores à faixa de valores estimados empiricamente, porém ainda assim coerentes com o esperado para as bacias, principalmente quando comparados aos valores obtidos na simulação com as configurações padrão do modelo.

Visando analisar a variação sazonal das estimativas de evapotranspiração geradas pelo SWAT, a Figura 23 apresenta a evapotranspiração mensal média obtida durante o período simulado para a bacia B2 - Ribeirão do Feijão, sendo exibidos tanto os valores estimados pelo modelo quanto os totais calculados através dos métodos empíricos.

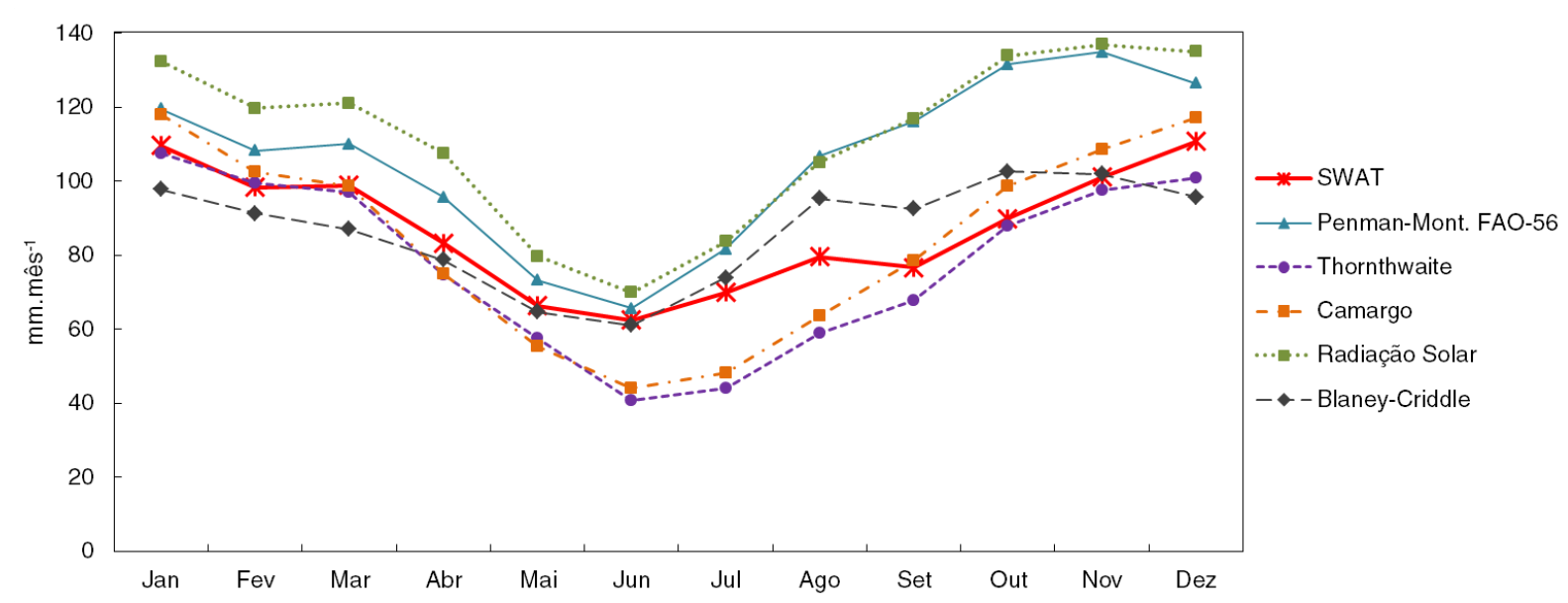

Figura 23 - Variação sazonal dos valores de evapotranspiração simulados pelo SWAT e estimados empiricamente para a Bacia do Ribeirão do Feijão. 
Verifica-se que a variação sazonal da evapotranspiração ao longo do ano também foi simulada de forma verossímil pelo SWAT quando comparada aos valores mensais obtidos através dos métodos empíricos. Os maiores valores foram observados durante a estação chuvosa (outubro a março), enquanto na estação seca (abril a setembro) foram obtidos os menores valores de evapotranspiração mensal. Tanto nos métodos empíricos como no SWAT, o mês de menor evapotranspiração foi junho, o qual apresentou valores entre 40 e 70 mm.mês ${ }^{-1}$. Já os meses de maior estimativa foram dezembro e janeiro, apresentando totais no intervalo entre 97 e 135 mm. mês ${ }^{-1}$. Tal similaridade entre a sazonalidade dos dados simulados e estimados através de métodos empíricos é devida, em grande parte, aos ajustes realizados nas operações de manejo das culturas, os quais visaram retratar os ciclos de cultura ocorrentes nas bacias.

A análise da Figura 23 permite ainda inferir que os métodos de Penman-Monteith FAO-56 e da Radiação Solar apresentaram os maiores valores mensais, enquanto o Método de Thornthwaite retratou as menores estimativas para a Bacia do Ribeirão do Feijão. Cunha (2003) realizou medições de evapotranspiração a partir de lisímetros instalados na região de São Carlos - SP, município no qual se insere boa parte da referida bacia, constatando que as estimativas obtidas através do Método de Thornthwaite são as que mais se aproximam da evapotranspiração obtida em campo. Através da Figura 23 é possível observar que a evapotranspiração mensal simulada pelo SWAT de fato apresentou boa correspondência com os valores obtidos pelo Método de Thornthwaite, principalmente na estação chuvosa. Já nos meses mais secos (de maio a setembro), os valores simulados foram superiores ao estimados pelo Método de Thornthwaite.

Em relação aos demais componentes do balanço hídrico apresentados na Figura 21, verificou-se que em todas as bacias analisadas houve uma redução dos processos relacionados à água no solo, bem como na contribuição dos escoamentos para o canal. Em termos percentuais médios, o escoamento superficial apresentou uma redução média de $28 \%$ nas cinco bacias, o escoamento por fluxo lateral uma redução de $22 \%$, a recarga do aquífero raso uma redução de $58 \%$ e, por fim, o fluxo de base uma redução de $57 \%$.

Tal comportamento observado em relação aos demais componentes do balanço hídrico é esperado, visto que as modificações no ciclo de desenvolvimento vegetal alteraram a dinâmica hidrológica das bacias simuladas. Uma maior parcela da precipitação passou a ser retida no dossel das plantas e posteriormente evaporada, reduzindo o volume de água que chega ao solo e escoa/infiltra. A modificação do crescimento vegetal, além de alterar a 
quantidade de água perdida por transpiração, aumentou também a demanda por parte das plantas, contribuindo para a redução da água armazenada no perfil de solo. Tais fatores ocasionaram não somente a redução da recarga do aquífero, como também a contribuição dos fluxos lateral e de base para o canal.

Os resultados obtidos na Simulação Modificada para a Bacia do Ribeirão do Feijão podem ser comparados com o estudo conduzido por Barreto (2006) na Bacia do Ribeirão da Onça, onde foram estimados experimentalmente diversos aspectos referentes à hidrologia e hidrogeologia da área no ano de 2005. Tal comparação é possível devido à pequena distância entre as bacias, visto que ambos os cursos d'água são afluentes formadores do Rio JacaréGuaçú, além de apresentarem morfometria, uso da terra e regime climático semelhantes. Além disso, o período simulado para a Bacia do Ribeirão do Feijão (1980 a 2007) engloba o período analisado no Ribeirão da Onça (ano de 2005), permitindo a comparação do mesmo intervalo de tempo, conforme apresentado na Figura 24.

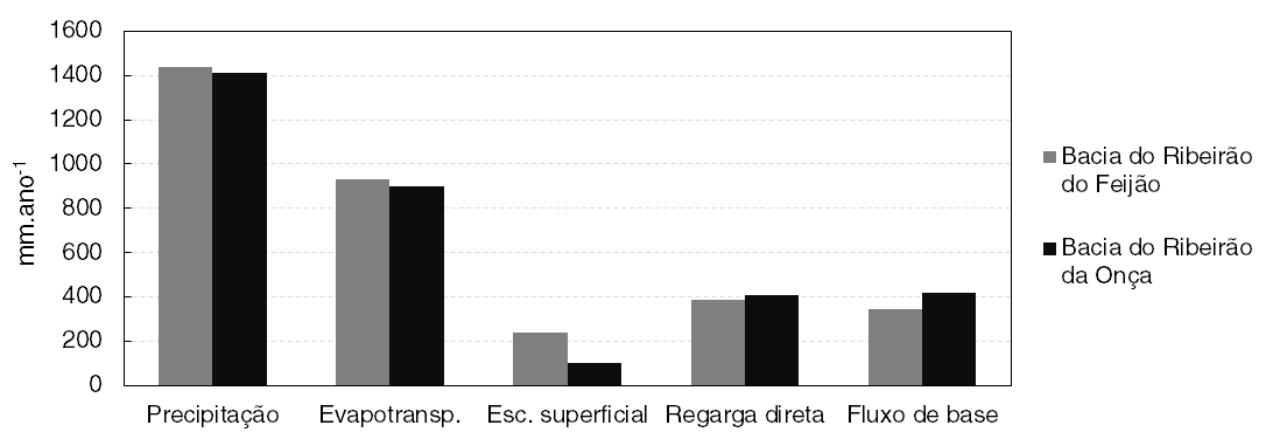

Figura 24 - Comparação entre as estimativas experimentais obtidas para o Ribeirão da Onça e os resultados simulados pelo SWAT para o Ribeirão do Feijão no ano de 2005.

Verifica-se que a precipitação anual calculada para as bacias foi bastante próxima, sendo de 1439 mm na Bacia do Ribeirão do Feijão e 1410 mm na Bacia do Ribeirão da Onça. A evapotranspiração obtida através do método do balanço hídrico por Barreto (2006) foi estimada em 900 mm anuais no Ribeirão da onça, o que corresponde a cerca de $64 \%$ da precipitação anual que cai sobre a bacia. $\mathrm{O}$ valor da evapotranspiração simulada pelo SWAT no Ribeirão do Feijão foi de $933 \mathrm{~mm}$ no mesmo ano, perfazendo aproximadamente $65 \%$ da precipitação anual, percentual muito próximo ao obtido experimentalmente.

O escoamento superficial foi o componente de maior discrepância entre os estudos, sendo estimado o valor de $239 \mathrm{~mm}$ através da simulação com o SWAT, o que corresponde a cerca de $17 \%$ da precipitação anual . No estudo de Barreto (2006) a estimativa do escoamento 
superficial direto se deu através de um modelo chuva-vazão calibrado para a bacia, sendo obtido o valor de $102 \mathrm{~mm}$ anuais, o que corresponde a aproximadamente $7 \%$ do total precipitado.

A recarga direta foi estimada por Barreto (2006) através da análise da variação do freático e pela identificação e extrapolação das curvas de recessão do nível do aquífero, sendo obtido o valor de $407 \mathrm{~mm}$ anuais. O valor estimado pelo SWAT na Bacia do Ribeirão do Feijão apresentou proximidade, sendo de $389 \mathrm{~mm}$. Por fim, o fluxo de base simulado na bacia do Ribeirão do Feijão foi de $345 \mathrm{~mm}$, enquanto o valor obtido experimentalmente no Ribeirão da Onça pela correlação com o nível do aquífero foi de $419 \mathrm{~mm}$.

\subsection{Simulação de vazão nas bacias}

Nesta seção são apresentados os resultados da simulação de vazão para os postos fluviométricos das cinco bacias analisadas no estudo, tanto para a Simulação Padrão quanto para a Simulação Modificada. As estatísticas de precisão aqui exibidas referem-se a todo o período simulado, ainda sem distinção entre os intervalos de calibração e validação. Tal análise visa, neste primeiro momento, comparar como as alterações propostas neste trabalho influenciaram a simulação da vazão. Deste modo, são apresentados na Tabela 16 o Coeficiente de Eficiência de Nash-Sutcliffe (NSE) e o Percentual de Tendência (PBIAS) para a Simulação Padrão.

Tabela 16 - Estatísticas referentes às simulações de vazão nos postos fluviométricos das bacias obtidos na Simulação Padrão

\begin{tabular}{cccccc}
\hline \multirow{2}{*}{ Posto } & \multicolumn{2}{c}{ NSE } & & \multicolumn{2}{c}{ PBIAS (\%) } \\
\cline { 2 - 3 } \cline { 5 - 6 } & Mensal & Diário & & Mensal & Diário \\
\hline P1 & $-6,2$ & $-10,6$ & & $-144,2$ & $-141,3$ \\
P2 & $-20,9$ & $-26,5$ & & $-70,6$ & -69 \\
P3 & $-2,9$ & $-3,4$ & & $-105,6$ & -104 \\
P4-I & $-10,5$ & $-16,6$ & & -86 & $-84,6$ \\
P4-II & $-7,3$ & $-10,4$ & & $-52,3$ & $-50,9$ \\
P5-I & $-2,5$ & $-6,4$ & & -92 & -91 \\
P5-II & 0,03 & $-1,5$ & & $-41,5$ & $-40,8$ \\
P5-III & $-0,9$ & $-5,4$ & & $-47,1$ & $-46,4$ \\
\hline
\end{tabular}


Através da Tabela 16 verifica-se que o posto fluviométrico que apresentou melhores resultados foi o posto P5-II, situado na Bacia do Alto Paranapanema (B5), o qual apresentou valores de NSE de 0,03 na simulação mensal e -1,5 na simulação diária. Por outro lado, a pior simulação foi verificada no posto P2, situado na Bacia do Ribeirão do Feijão, onde obteve-se NSE mensal de -20,9 e diário de -26,5. Para todos os postos, a simulação mensal apresentou melhores resultados do que a simulação diária, o que é esperado visto a maior dificuldade de predição em escalas de tempo menores.

A análise dos valores de PBIAS releva que em todas as simulações, sem exceção, os valores simulados pelo SWAT foram superestimados em relação aos valores observados nos postos fluviométricos. As maiores superestimavas ocorreram no posto P1, na Bacia do Córrego Cana-do-Reino, onde a série de vazões simuladas foi 144,2\% maior na simulação mensal e 141,3\% maior na simulação diária. O posto de menor superestimativa foi o P5-II, no Alto Paranapanema, onde observou-se que a série simulada superestimou os dados observados em 41,5\% na simulação mensal e em 40,8\% na simulação diária.

A análise dos valores de NSE na Simulação Modificada, apresentados na Tabela 17, permite inferir que em todos os postos fluviométricos o ajuste entre dados observados e simulados foi melhor do que na Simulação Padrão, fato constatado pelos maiores valores de NSE obtidos tanto em passo mensal quanto diário.

Tabela 17 - Estatísticas referentes às simulações de vazão nos postos pluviométricos das bacias obtidos na Simulação Modificada

\begin{tabular}{cccccc}
\hline \multirow{2}{*}{ Posto } & \multicolumn{2}{c}{ NSE } & & \multicolumn{2}{c}{ PBIAS (\%) } \\
\cline { 2 - 3 } \cline { 5 - 6 } & Mensal & Diário & & Mensal & Diário \\
\hline P1 & $-0,95$ & $-1,6$ & & $-23,8$ & $-22,3$ \\
P2 & $-5,82$ & $-9,6$ & & -30 & $-28,8$ \\
P3 & 0,18 & 0,09 & & $-7,2$ & $-6,49$ \\
P4-I & $-2,7$ & $-3,3$ & & 13,7 & 14,5 \\
P4-II & $-1,2$ & $-2,9$ & & 24,1 & 24,8 \\
P5-I & 0,23 & $-1,2$ & & $-16,9$ & $-16,2$ \\
P5-II & 0,64 & 0,15 & & 13,9 & 14,4 \\
P5-III & 0,32 & $-0,76$ & & 3,2 & 3,7 \\
\hline
\end{tabular}

Os valores de NSE mensais, que antes se encontravam na faixa de $-20,9$ a 0,03 , passaram ao intervalo de $-5,82$ a 0,64 após as modificações realizadas no modelo. Já o NSE diário passou da faixa de $-26,5$ a $-1,5$ para o intervalo de $-9,6$ a 0,15 . A bacia de pior desempenho continuou sendo a Bacia do Ribeirão do Feijão, responsável pelos menores 
valores dentre todas as cinco bacias, enquanto a simulação de melhor desempenho foi novamente obtida no posto P5-II do Alto Paranapanema.

Quanto aos valores de PBIAS da Simulação Modificada, verifica-se que todos os postos fluviométricos apresentaram aumento absoluto do percentual de tendência. Tal fato evidencia uma redução das superestimavas de vazão observadas anteriormente, indicando uma diminuição dos valores de vazão simulados. O posto fluviométrico de pior desempenho segundo tal critério passou a ser o do Ribeirão do Feijão (P2), onde obteve-se superestimativa de $30 \%$ na vazão mensal e de $28,8 \%$ na vazão diária. Já o posto de menor viés observado foi o P5-III, da Bacia do Alto Paranapanema, na qual os valores simulados passaram a apresentar uma leve subestimativa de 3,2\% na simulação mensal e 3,7\% na simulação diária.

A comparação entre as estatísticas obtidas nas Simulações Padrão e Modificada corrobora com a análise dos componentes do balanço hídrico apresentada anteriormente. $\mathrm{Na}$ simulação com as configurações originais do modelo, os valores elevados das componentes de escoamento superficial, fluxo lateral e fluxo de base levaram a uma superestimativa da vazão simulada pelo modelo. Tal comportamento é fortemente perceptível na estimativa dos picos de vazão, sendo reportado por um grande número de trabalhos na literatura (ANDRADE; MELLO; BESKOW, 2013; CASTRO, 2013; CARVALHO, 2014; VEIGA, 2014; ARROIO JUNIOR; MAUAD, 2015; VILLELA, 2015; BRIGHENTI; BONUMÁ; CHAFFE, 2016).

Com as alterações propostas na Simulação Modificada, o aumento da evapotranspiração levou a uma diminuição significativa do escoamento superficial, do fluxo lateral e do fluxo de base, o que, por sua vez, ocasionou a redução da vazão, reduzindo a discrepância entre valores simulados e observados. Uma análise mais detalhada do comportamento da vazão frente às alterações pode ser inferida a partir da análise da Figura 25, onde, novamente utilizando a Bacia do Ribeirão do Feijão como exemplo, são apresentados trechos dos hidrogramas mensal e diário gerados. Os trechos selecionados para análise compreendem a década de 1990 para a simulação mensal e o ano de 1995 para a simulação diária, escolhidos devido ao fato de conterem os maiores picos de vazão observados na série fluviométrica total.

A análise da Figura 25 (a) evidencia que os picos de vazão simulados correspondem aos picos observados, embora apresentem grande superestimativa. A maior vazão mensal média observada foi de $10,3 \mathrm{~m}^{3} \cdot \mathrm{s}^{-1}$ em fevereiro de 2005, valor que foi estimado em 30,7 $\mathrm{m}^{3} \cdot \mathrm{s}^{-1}$ na Simulação Padrão, passando a $14,5 \mathrm{~m}^{3} \cdot \mathrm{s}^{-1}$ na Simulação Modificada. Outro mês de destaque foi janeiro de 1999, no qual a vazão observada foi de $8,6 \mathrm{~m}^{3} . \mathrm{s}^{-1}$; enquanto na Simulação Padrão foi de $27,8 \mathrm{~m}^{3} \cdot \mathrm{s}^{-1}$ e na Modificada passou a $13,2 \mathrm{~m}^{3} \cdot \mathrm{s}^{-1}$. Desse modo, 
verifica-se que os maiores picos mensais foram superestimados cerca de $200 \%$ na Simulação Padrão, enquanto na Simulação Modificada a superestimativa em relação aos dados observados ficou em torno de 50\%. Já em relação aos meses mais secos, verifica-se que ambas as simulações apresentaram subestimativa de vazões, porém os valores da segunda simulação foram levemente superiores aos da primeira, aproximando-se mais dos valores observados.
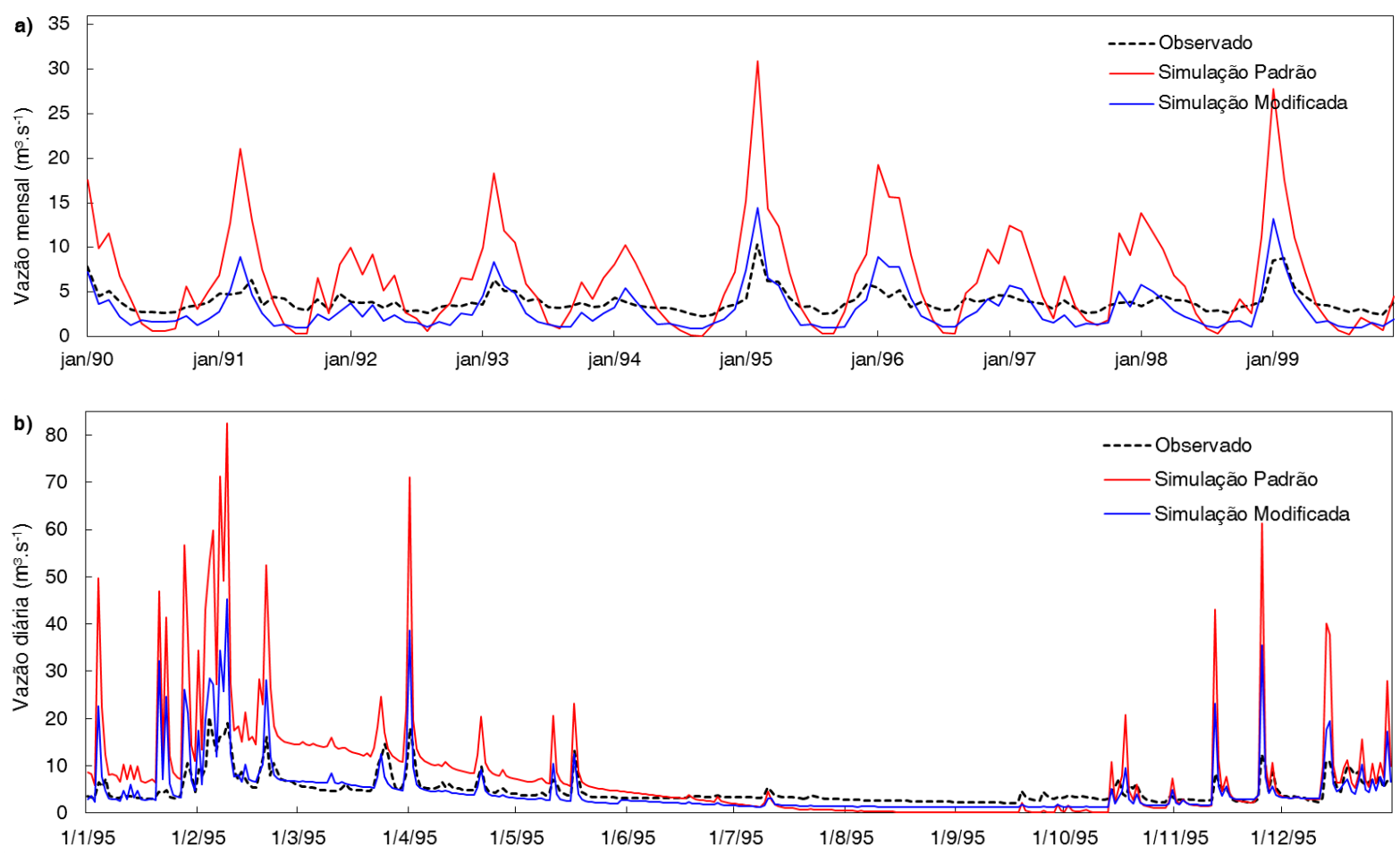

Figura 25 - Vazões observadas e simuladas no posto fluviométrico do Ribeirão do Feijão. (a)

Vazão mensal durante a década de 1990. (b) Vazão diária durante o ano de 1995.

Em relação à série diária apresentada na Figura 25 (b), podem ser inferidas as mesmas constatações realizadas para a série mensal, onde verifica-se superestimativa de vazão nos meses chuvosos, sendo esta mais acentuada nos valores extremos. O maior pico medido no posto fluviométrico ocorreu em $9 / 2 / 95$, sendo de $20,3 \mathrm{~m}^{3} \cdot \mathrm{s}^{-1}$. Na Simulação Padrão tal pico foi estimado com o valor de $82,47 \mathrm{~m}^{3} \cdot \mathrm{s}^{-1}$, uma superestimativa de mais de $300 \%$, enquanto na Simulação Modificada o novo valor foi de $45,3 \mathrm{~m}^{3} \cdot \mathrm{s}^{-1}$, valor ainda superestimado em $125 \%$. Outro pico de vazão significativo ocorreu em 1/4/95, no qual a vazão observada foi de 17,9 $\mathrm{m}^{3} \cdot \mathrm{s}^{-1}$, a determinada na Simulação Padrão foi de $71,2 \mathrm{~m}^{3} \cdot \mathrm{s}^{-1}$ (superestimativa de $297 \%$ ) e a obtida na Simulação Modificada foi de $38,7 \mathrm{~m}^{3} \cdot \mathrm{s}^{-1}$ (superestimativa de $116 \%$ ). Em 
contrapartida, os meses da estação seca (junho a outubro) apresentaram subestimativa das vazões simuladas em comparação à observada, fato também constatado na simulação mensal.

Os resultados apresentados nesta seção tiveram como objetivo avaliar a melhoria da simulação de vazão frente às mudanças propostas no processo de modelagem através da comparação entre as simulações. Conforme observado, as alterações realizadas permitiram obter uma representação mais realista do balanço hídrico nas bacias, o que se traduziu em uma sensível melhoria dos indicadores estatísticos da simulação. Entretanto, os resultados obtidos ainda não permitem classificar a simulação como satisfatória, visto que o procedimento de calibração é fundamental para melhor parametrizar o modelo em relação às condições locais, reduzindo assim as incertezas relativas à predição.

\subsection{Calibração e validação da vazão}

A calibração das simulações para a vazão foi realizada de forma automatizada através do software SWAT-CUP, valendo-se do algoritmo SUFI-2 (Sequential Uncertainty Fitting Version 2). O procedimento foi executado a partir do banco de dados da Simulação Modificada, visto que esta apresentou melhor aderência em relação aos dados observados quando comparada à Simulação Padrão.

Apesar de as modificações realizadas terem diminuído a diferença entre os picos de vazão simulados e observados, estes ainda encontravam-se superestimados em relação aos valores reais, enquanto nos períodos sem chuva a vazão simulada era subestimada. Nesse sentido, o procedimento de calibração visou principalmente à atenuação dos valores extremos através do ajuste do escoamento superficial, bem como o aumento da vazão nos períodos secos através do ajuste dos processos relacionados à água subterrânea.

A seleção das variáveis utilizadas na calibração da vazão foi inicialmente realizada com base em parâmetros reportados com frequência pela literatura, tanto nacional como internacional (ARNOLD et al., 2012b). Os parâmetros inicialmente selecionados são apresentados na Tabela 18, onde é exibida uma breve descrição do processo hidrológico no qual o parâmetro atua, os limites máximos e mínimos fixados para alteração do parâmetro durante a calibração e os valores ajustados na melhor simulação para cada uma das bacias hidrográficas, tanto em passo mensal quanto diário. 
Tabela 18 - Informações gerais sobre o procedimento de calibração das simulações: parâmetros modificados, descrição dos parâmetros, limites máximos e mínimos fixados para alteração e valores ajustados na melhor simulação.

\begin{tabular}{|c|c|c|c|c|c|c|c|c|c|c|c|c|c|}
\hline \multirow{2}{*}{$\begin{array}{l}\text { Parâmetro } \\
\text { modificado }\end{array}$} & \multirow{2}{*}{ Descrição do parâmetro } & \multirow{2}{*}{$\begin{array}{l}\text { Limite } \\
\text { mín. }\end{array}$} & \multirow{2}{*}{$\begin{array}{l}\text { Limite } \\
\text { máx. }\end{array}$} & \multicolumn{5}{|c|}{ Valores ajustados (Simulação mensal) } & \multicolumn{5}{|c|}{ Valores ajustados (Simulação diária) } \\
\hline & & & & B1 & B2 & B3 & B4 & B5 & B1 & B2 & B3 & B4 & B5 \\
\hline ALPHA_BF.gw & Fator alfa de recessão do fluxo de base (dias) & $\mathbf{0}$ & 0,5 & 0,42 & 0,38 & 0,23 & 0,49 & 0,47 & 0,48 & 0,21 & 0,43 & 0,26 & 0,45 \\
\hline GWQMN.gw & $\begin{array}{l}\text { Profundidade limite de água no aquífero raso para } \\
\text { ocorrer fluxo de retorno (mm) }\end{array}$ & $\mathbf{0}$ & 100 & 1,46 & 25,4 & 1,83 & 54,4 & 5,17 & 4,34 & 0,25 & 3,57 & 2,24 & 4,31 \\
\hline GW_DELAY.gw & Intervalo de recarga do aquífero raso (dias) & $\mathbf{0}$ & 100 & 49 & 60 & 45 & 99 & 70 & 68 & 49 & 40 & 81 & 68 \\
\hline GW_REVAP.gw & $\begin{array}{l}\text { Coeficiente de re-evaporação da água do aquífero } \\
\text { raso para a zona insaturada }\end{array}$ & $\mathbf{0 , 0 2}$ & 0,2 & 0,07 & 0,14 & 0,19 & 0,02 & 0,12 & 0,09 & 0,13 & 0,2 & 0,12 & 0,15 \\
\hline REVAPMN.gw & $\begin{array}{l}\text { Profundidade de água limite no aquífero raso para } \\
\text { que ocorra "revap" para a zona insaturada (mm) }\end{array}$ & $\mathbf{0}$ & 100 & - & - & - & 56,25 & - & - & - & - & - & - \\
\hline SOL_BD.sol* & Densidade do solo $\left(\mathrm{g} . \mathrm{cm}^{-3}\right)$ & $-25 \%$ & $+25 \%$ & $-22,2 \%$ & $-24,8 \%$ & $18,4 \%$ & $15,3 \%$ & $-2,3 \%$ & $-23,4 \%$ & $-24,3 \%$ & $23,5 \%$ & $-18,1 \%$ & $-3,4 \%$ \\
\hline SOL_K.sol ${ }^{*}$ & Condutividade hidráulica saturada $\left(\mathrm{mm} \cdot \mathrm{h}^{-1}\right)$ & $-50 \%$ & $+\mathbf{5 0 \%}$ & $37,5 \%$ & $-36,9 \%$ & $46,4 \%$ & $-8,4 \%$ & $2,9 \%$ & $47,2 \%$ & $3,7 \%$ & $8,3 \%$ & $14,1 \%$ & $23,5 \%$ \\
\hline SOL_AWC.sol ${ }^{*}$ & Capacidade de água disponível no solo (mm) & $-50 \%$ & $+\mathbf{5 0 \%}$ & $32,1 \%$ & $43 \%$ & $-0,2 \%$ & $-29,7 \%$ & $17,2 \%$ & $21,9 \%$ & $49,4 \%$ & $-10,2 \%$ & $-38,7 \%$ & $15,8 \%$ \\
\hline $\mathrm{CN} 2 . \mathrm{mgt}^{*}$ & $\begin{array}{l}\text { Valor da curva número para a condição de } \\
\text { umidade II }\end{array}$ & $-20 \%$ & $+20 \%$ & $-13,2 \%$ & $-17,4 \%$ & $-14,4 \%$ & $-2,3 \%$ & $-19,1 \%$ & $-18,9 \%$ & $-19,8 \%$ & $-14,3 \%$ & $-19,4 \%$ & $-12 \%$ \\
\hline ALPHA_BNK.rte & $\begin{array}{l}\text { Fator alpha do fluxo de base para o } \\
\text { armazenamento marginal (dias) }\end{array}$ & $\mathbf{0}$ & 0,5 & 0,08 & 0,47 & 0,46 & 0,49 & 0,47 & 0,09 & 0,44 & 0,45 & 0,32 & 0,48 \\
\hline CH_N2.rte & Coeficiente de Manning para o canal principal & $\mathbf{0}$ & $\mathbf{0 , 3}$ & 0,2 & 0,29 & 0,14 & 0,1 & 0,2 & 0,04 & 0,29 & 0,04 & 0,16 & 0,07 \\
\hline CH_K2.rte & $\begin{array}{l}\text { Condutividade hidráulica do canal principal } \\
\left(\mathrm{mm} \cdot \mathrm{h}^{-1}\right)\end{array}$ & 5 & 130 & 4,84 & 84,7 & 61,1 & 84 & 36,9 & 33,7 & 5,85 & 66,8 & 48,04 & 100 \\
\hline ESCO.hru & Fator de compensação de evaporação do solo & 0,7 & 1 & 0,96 & 0,74 & 0,81 & 0,93 & 0,97 & 0,96 & 0,74 & 0,93 & 0,98 & 0,99 \\
\hline LAT_TTIME.hru & Tempo para o fluxo lateral atingir o canal (dias) & $\mathbf{0}$ & 180 & - & - & - & 113,41 & 15,84 & - & 11,58 & - & 177,6 & 3,2 \\
\hline SLSUBBSN.hru ${ }^{*}$ & Comprimento do declive médio (m) & $-25 \%$ & $+25 \%$ & - & $-24,4 \%$ & - & $23,4 \%$ & $-11,3 \%$ & $-4,2 \%$ & $19,5 \%$ & - & $-20 \%$ & $3,4 \%$ \\
\hline CANMX.hru & $\begin{array}{l}\text { Armazenamento máximo de água no dossel } \\
\text { vegetativo }(\mathrm{mm})\end{array}$ & $\mathbf{0}$ & 10 & - & - & - & - & - & - & 6,54 & - & - & - \\
\hline SURLAG.bsn & Coeficiente de retardo do escoamento superficial & 0,05 & 24 & - & - & - & 12,6 & 19,6 & 1,2 & 6,14 & - & 14,6 & 23,5 \\
\hline
\end{tabular}

* Indica que o ajuste do parâmetro realizado por meio de multiplicação dos valores originais, de modo a realizar a alteração proporcionalmente.

(-) Indica que o parâmetro não foi incluído na calibração da referida simulação. 
Os parâmetros selecionados para as calibrações compreendem em sua maioria variáveis relacionadas à água subterrânea (ALPHA_BF, GWQMN, GW_DELAY, GW_REVAP e REVAPMN), parâmetros relacionados às propriedades físico-hídricas do perfil de solo (SOL_BD, SOL_K, SOL_AWC) e parâmetros relacionados à movimentação e distribuição da água e demais componentes pelos canais da bacia (ALPHA_BNK, CH_N2 e CH_K2).

Os parâmetros SOL_BD, SOL_K, SOL_AWC e CN2 representam propriedades intrínsecas a cada tipo de solo/uso da terra, apresentando, portanto, diferentes valores nas HRUs das bacias. Por este motivo, tais parâmetros foram modificados através do método de multiplicação de valores, sendo alterados de forma distribuída, embora sempre na mesma proporção para todas as HRUs. Já os demais parâmetros, por serem únicos e não variarem espacialmente nas bacias, foram modificados por meio da substituição direta de valores.

Os campos "limite mínimo" e "limite máximo" da Tabela 18 referem-se ao nível de liberdade que se atribuiu à variação de cada parâmetro. Estes limites são importantes para se evitar distorções na modelagem, bem como a geração de resultados não compatíveis com a realidade (CARVALHO, 2014). Conforme ressaltam Van Liew, Arnold e Bosch (2005), a seleção destes limites para variação dos parâmetros deve ser realizada com cautela, de modo a assegurar que os valores finais calibrados sejam realmente representativos das condições das bacias hidrográficas. Desse modo, tal processo é fortemente dependente da familiaridade do usuário com os parâmetros do modelo e do conhecimento hidrológico sobre as bacias.

O parâmetro ALPHA_BF, em síntese, reflete a resposta das águas subterrâneas às mudanças no fluxo de recarga. Varia de 0,1 a 0,3 em áreas com resposta lenta à descarga e de 0,9 a 1,0 em áreas de resposta rápida (SMEDEMA; RYCROFT, 1983). O intervalo de variação do parâmetro GWQMN foi configurado entre 0 e 100, de forma a permitir a alimentação constante do rio através do fluxo de água subterrânea. Já o parâmetro GW_DELAY, referente à defasagem de tempo em dias entre o momento em que a água sai do perfil do solo e entra no aquífero superficial, foi limitado entre 0 e 100. Segundo Richards et al. (2010), tal parâmetro pode ser estimado experimentalmente através da observação da flutuação do nível da água subterrânea frente aos eventos de precipitação.

O parâmetro GW_REVAP representa a transferência da água do aquífero raso para a zona insaturada logo acima, podendo ocorrer devido à evaporação da franja capilar nos períodos de estiagem ou pela retirada por plantas com raízes profundas. Valores próximos de zero indicam movimento de água restringido, enquanto valores próximos de 1 indicam taxa de transferência próxima às taxas de evapotranspiração potencial. O intervalo estipulado para tal 
parâmetro foi de ente 0,02 e 0,20 (NEITSCH et al., 2011). Já o parâmetro REVAPMN, que controla a profundidade de água limite no aquífero raso para que ocorra a evaporação, foi inserido apenas em bacias onde foi necessário um melhor ajuste dos processos subterrâneos, sendo permitida a variação entre 0 e 100 .

Para os parâmetros SOL_BD, SOL_K, SOL_AWC, referentes à densidade, condutividade hidráulica e capacidade de água disponível do solo, foi permitida uma variação de $\pm 25 \%$, $\pm 50 \%$ e $\pm 50 \%$ do valor original, intervalo adotado por diversos trabalhos na literatura (FARAMARZI et al., 2008; ANDRADE; MELLO; BESKOW, 2013; SAYYAD et al., 2015). É importante ressaltar que, pelo fato de tais parâmetros apresentarem diferentes valores conforme o tipo e a camada do perfil de solo, a modificação foi realizada de maneira proporcional para todas as unidades, através de variação percentual. De modo semelhante, para o parâmetro CN2, Van Liew, Arnold e Bosch (2005) consideram como plausível um intervalo de variação de $\pm 10 \%$, enquanto o valor sugerido pelo SWAT-CUP é de $\pm 20 \%$, sendo este último adotado neste trabalho.

O fluxo lateral é simulado com uma curva de recessão similar à curva usada para a água subterrânea, sendo caracterizado pelo parâmetro ALPHA_BNK. Desse modo, foi utilizado o mesmo intervalo de variação do parâmetro ALPHA_BF. O parâmetro CH_K2, referente à condutividade hidráulica do canal, governa o movimento da água a partir do leito do rio para o subsolo, sendo adotado o intervalo padrão de 5 a 130 (CONFESOR; WHITTAKER, 2007). Já o parâmetro CH_N2, relativo ao coeficiente de Manning para o canal principal, foi mantido entre 0 e 0,3 .

O parâmetro ESCO modifica a profundidade usada para determinar a demanda evaporativa do solo, de forma a levar em consideração o efeito da capilaridade. Na medida em que os valores diminuem, o modelo é capaz de extrair mais água de níveis mais baixos. $\mathrm{O}$ intervalo adotado para tal parâmetro foi de 0,7 a 1 (NEITSCH et al., 2011). Os parâmetros LAT_TTIME, SLSUBBSN, CANMX e SURLAG foram sendo adicionados em iterações posteriores, sendo inseridos nas simulações nas quais a função-objetivo não apresentou valores satisfatórios com os parâmetros e intervalos adotados nas iterações iniciais.

São também exibidos na Tabela 18 os ajustes dos parâmetros referentes às melhores simulações obtidas para as cinco bacias calibradas, tanto em escala mensal quanto diária. Ainda que no decorrer das iterações os intervalos máximos e mínimos tenham sido alterados visando à minimização das incertezas e otimização do processo de calibração, os valores ajustados finais situaram-se dentro dos limites previamente estabelecidos para variação dos parâmetros nas bacias. 
Na Tabela 19 são apresentados os valores de NSE e PBIAS referentes à melhor simulação obtida durante o processo de calibração, sendo também exibidas as estatísticas obtidas na validação. As cores na tabela indicam a classificação do desempenho do modelo segundo Moriasi et al. (2007), na qual o valor de NSE entre 0,75 e 1,00 é considerado como "muito bom", entre 0,65 e 0,75 considerado como "bom", entre 0,50 e 0,65, "satisfatório" e inferior a 0,50 , “insatisfatório". Já para o PBIAS, valor inferior a $\pm 10 \%$ é considerado como "muito bom", valor entre $\pm 10 \%$ e $\pm 15 \%$ é considerado como "bom", entre $\pm 15 \%$ e $\pm 25 \%$, "satisfatório" e valor superior a $\pm 25 \%$, "insatisfatório". Complementarmente, são exibidos na Figura 26 os gráficos de dispersão da vazão mensal observada versus simulada que resultaram em tais estatísticas, enquanto na Figura 27 são exibidos os gráficos para as simulações diárias.

Tabela 19 - Estatísticas de precisão obtidas nos períodos de calibração e validação e classificação do desempenho segundo Moriasi et al. $(2007)^{1}$.

\begin{tabular}{|c|c|c|c|c|c|c|c|c|}
\hline & \multicolumn{4}{|c|}{ Calibração } & \multicolumn{4}{|c|}{ Validação } \\
\hline & \multicolumn{2}{|c|}{ NSE } & \multicolumn{2}{|c|}{ PBIAS } & \multicolumn{2}{|c|}{ NSE } & \multicolumn{2}{|c|}{ PBIAS } \\
\hline & Mensal & Diário & Mensal & Diário & Mensal & Diário & Mensal & Diário \\
\hline $\mathbf{P 1}$ & 0,93 & 0,62 & $-1,9$ & $-3,3$ & 0,76 & 0,51 & $-12,7$ & $-19,7$ \\
\hline $\mathbf{P 2}$ & 0,71 & 0,51 & $+0,4$ & $-3,4$ & 0,62 & 0,38 & $-12,0$ & $-17,6$ \\
\hline P3 & 0,90 & 0,82 & $+2,1$ & $-21,5$ & 0,84 & 0,79 & $-16,6$ & $-6,3$ \\
\hline P4-I & 0,76 & 0,56 & $-20,1$ & $+3,1$ & 0,60 & 0,48 & $-20,8$ & $-18,6$ \\
\hline P4-II & 0,72 & 0,59 & $+2,5$ & $+8,5$ & 0,53 & 0,52 & $-19,7$ & $-5,5$ \\
\hline P5-I & 0,89 & 0,82 & $-10,8$ & $-8,4$ & 0,67 & 0,59 & $-31,3$ & $-30,8$ \\
\hline P5-II & 0,92 & 0,81 & $-0,7$ & $-0,1$ & 0,88 & 0,83 & $+8,4$ & $+8,2$ \\
\hline P5-III & 0,85 & 0,74 & $+4,7$ & $-0,1$ & 0,86 & 0,70 & $-9,1$ & $+11,1$ \\
\hline
\end{tabular}

${ }^{1}$ Classificação do desempenho segundo Moriasi et al. (2007):

Muito bom;

Bom;

Satisfatório;

Insatisfatório.

Através da análise da tabela é possível observar que em todas as calibrações os valores de NSE obtidos nas simulações mensais foram superiores aos obtidos nas simulações diárias. Mensalmente, os valores de NSE variaram de 0,71 a 0,93, correspondendo, segundo a classificação de desempenho de Moriasi et al. (2007), à faixa entre "bom" e "muito bom". Já nas simulações diárias o NSE variou entre 0,51 a 0,82 , correspondendo à faixa de "satisfatório" a "muito bom". 
a) Posto P1 - Calibração (2005 - 2010)

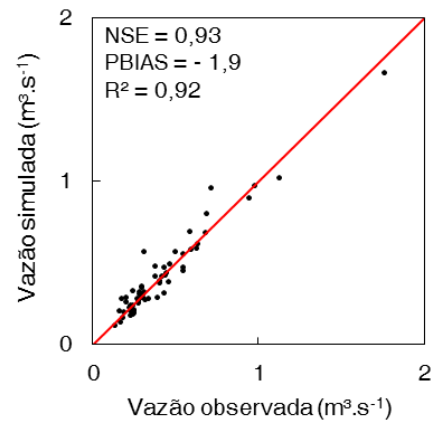

b) Posto P2 - Calibração (1984 - 1997)

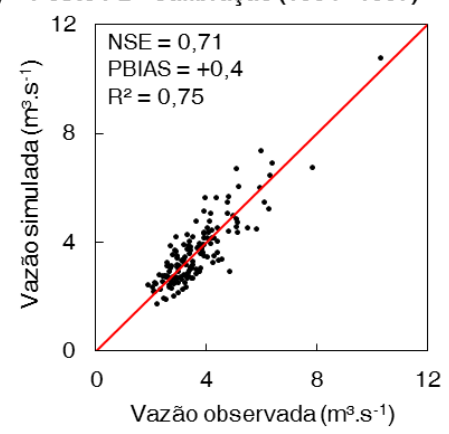

C) Posto P3 - Calibração (1998 - 2004)

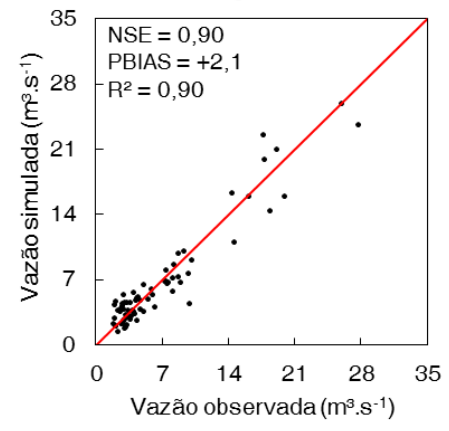

d) Posto P4-I - Calibração (1998 - 2006)

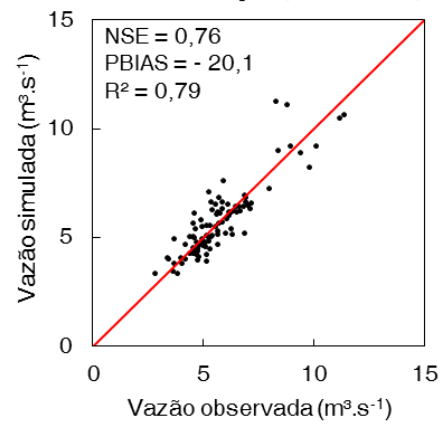

e) Posto P4-II - Calibração (1998 - 2006)

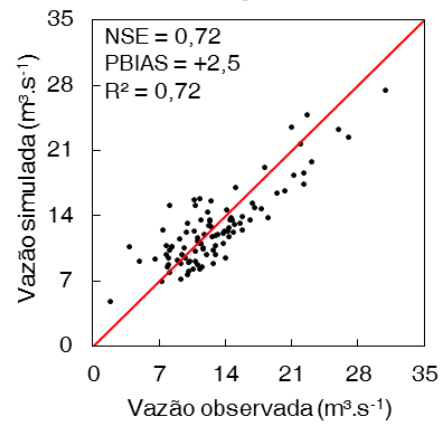

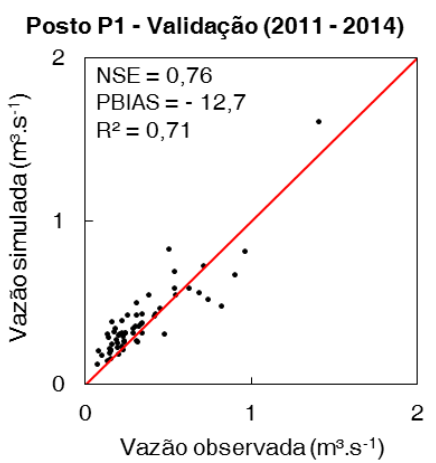

Posto P2 - Validação (1998 - 2007)

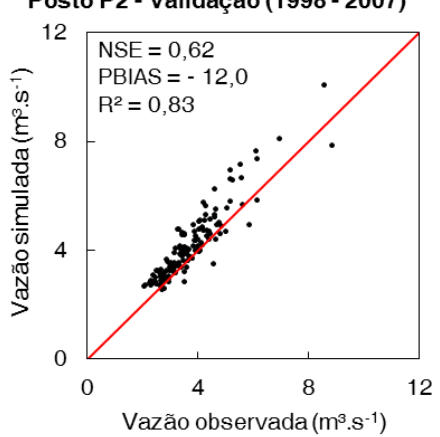

Posto P3 - Validação (2005 - 2009)

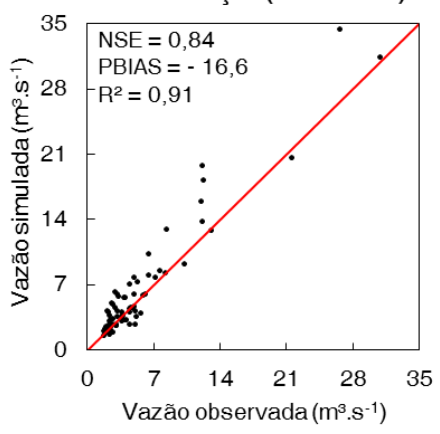

Posto P4-1 - Validação (2007 - 2013)

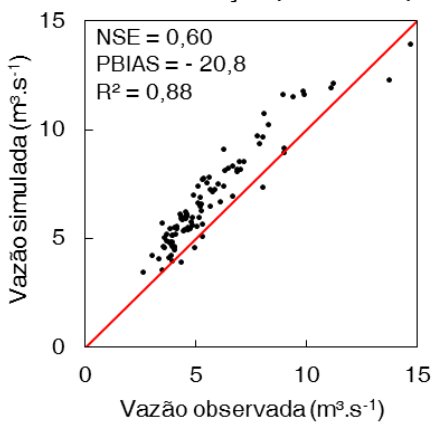

Posto P4-II - Validação (2007 - 2013)

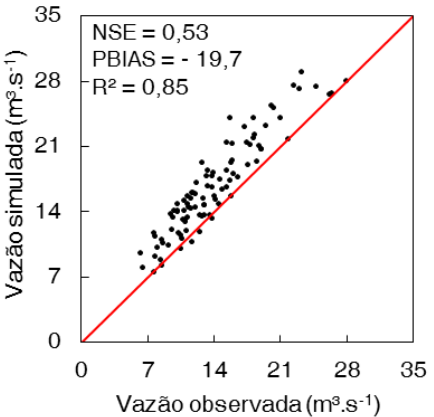



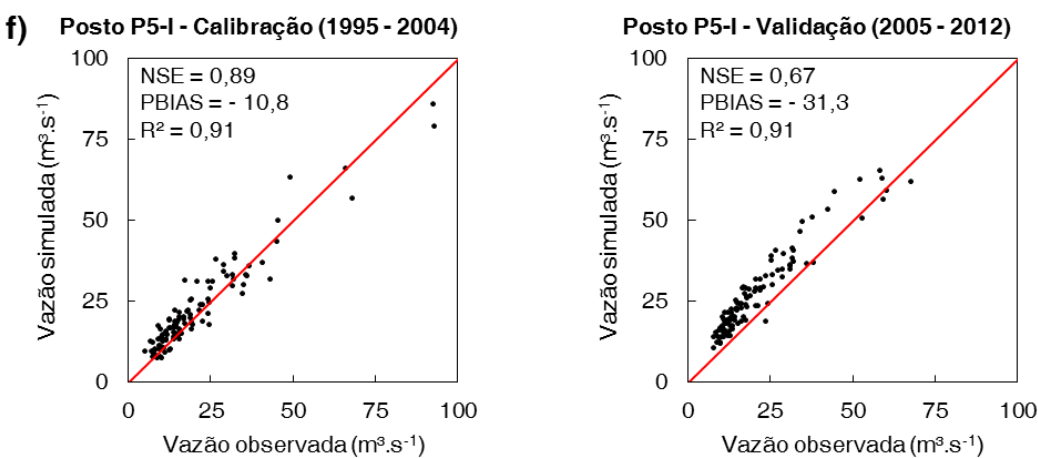

g) Posto P5-II - Calibração (1995 - 2004)

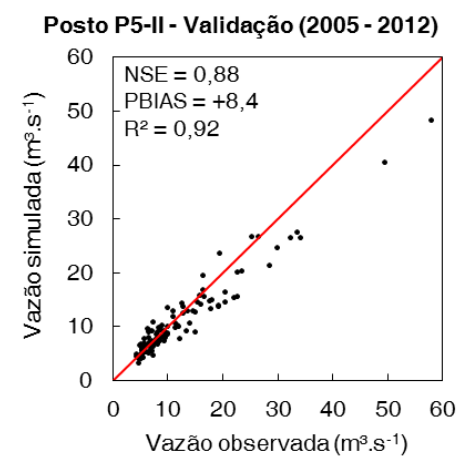

h) Posto P5-III - Calibração (1995 - 2004)

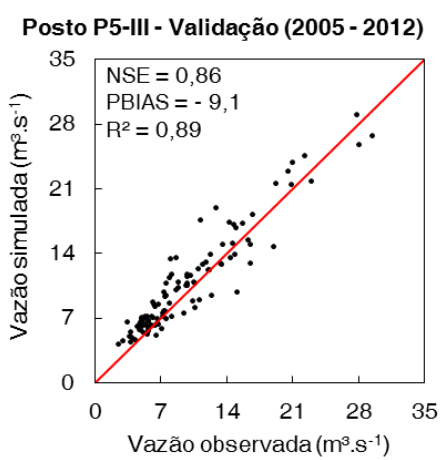

Figura 26 - Comparação entre a vazão mensal observada e simulada nos períodos de calibração e validação nos postos: (a) P1, (b) P2, (c) P3, (d) P4-I, (e) P4-II, (f) P5-I, (g) P5-II e (h) P5-III.

No período de validação verificou-se a mesma tendência de NSE mensais superiores aos diários em todos os postos fluviométricos. Os valores mensais da validação situaram-se entre 0,53 e 0,88 ("satisfatório" a "muito bom"), enquanto os valores diários situaram-se entre 0,38 e 0,83 ("insatisfatório" a "muito bom").

Ao compararem-se os valores de NSE na calibração com os obtidos na validação, nota-se que na maioria dos casos os valores da calibração foram superiores aos da validação. A análise dos gráficos de dispersão permite evidenciar que em grande parte destes casos há, no período de validação, valores extremos de vazão observada superiores aos valores do período de calibração, o que resulta em condições não previsíveis pelo modelo. Tal comportamento pode ser constatado ao observar os itens (c), (d) e (g) da Figura 26 e os itens (b), (d) e (f) da Figura 27. Em contrapartida, alguns postos apresentaram comportamento 
a) Posto P1 - Calibração (2005 - 2010)

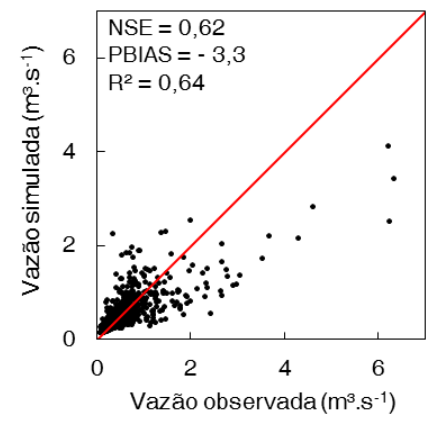

b) Posto P2 - Calibração (1984 - 1997)

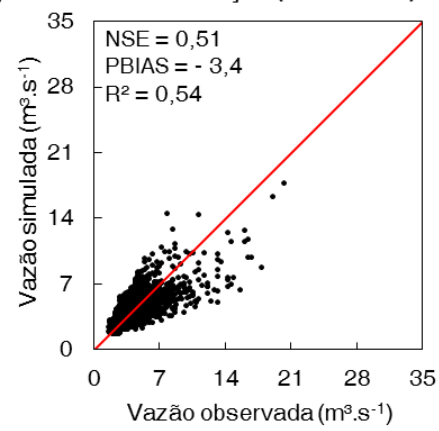

C) Posto P3 - Calibração (1998 - 2004)

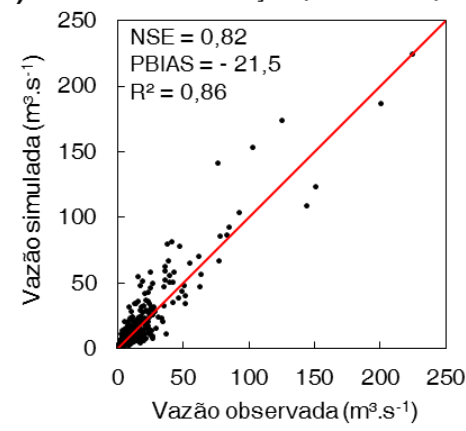

d) Posto P4-I - Calibração (1998 - 2006)

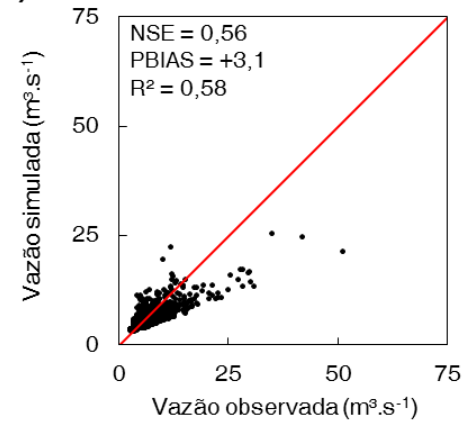

e) Posto P4-II - Calibração (1998 - 2006)

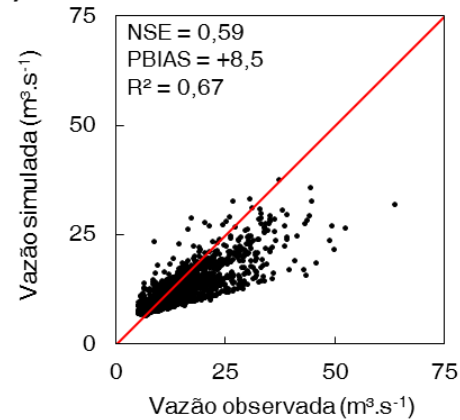

Posto P1 - Validação (2011 - 2014)

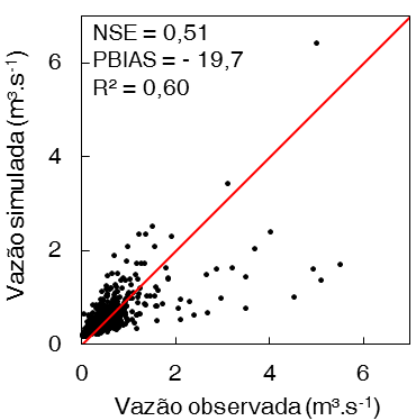

Posto P2 - Validação (1998 - 2007)

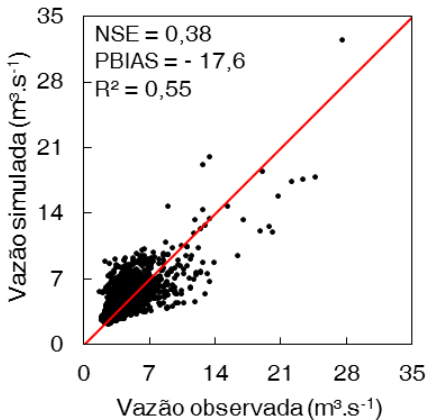

Posto P3 - Validação (2005 - 2009)

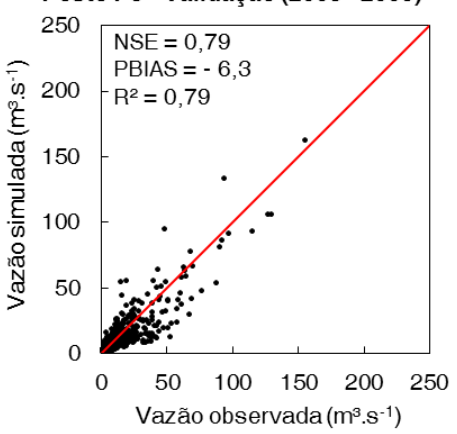

Posto P4-I - Validação (2007 - 2013)
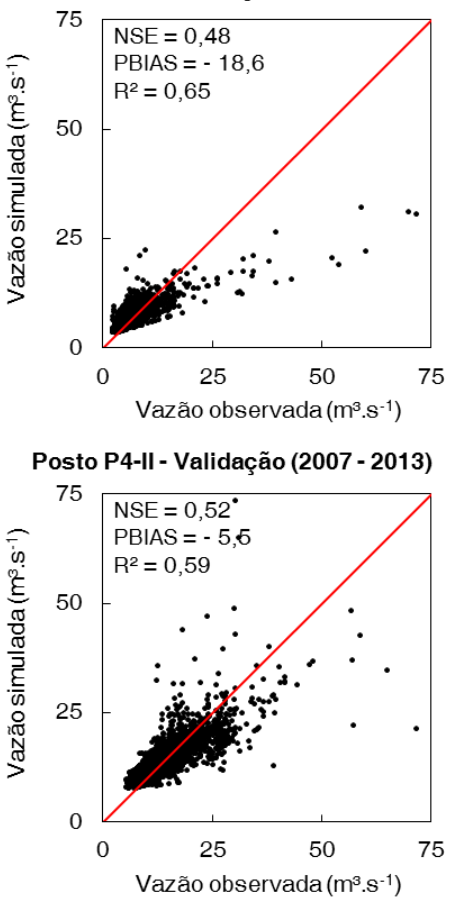

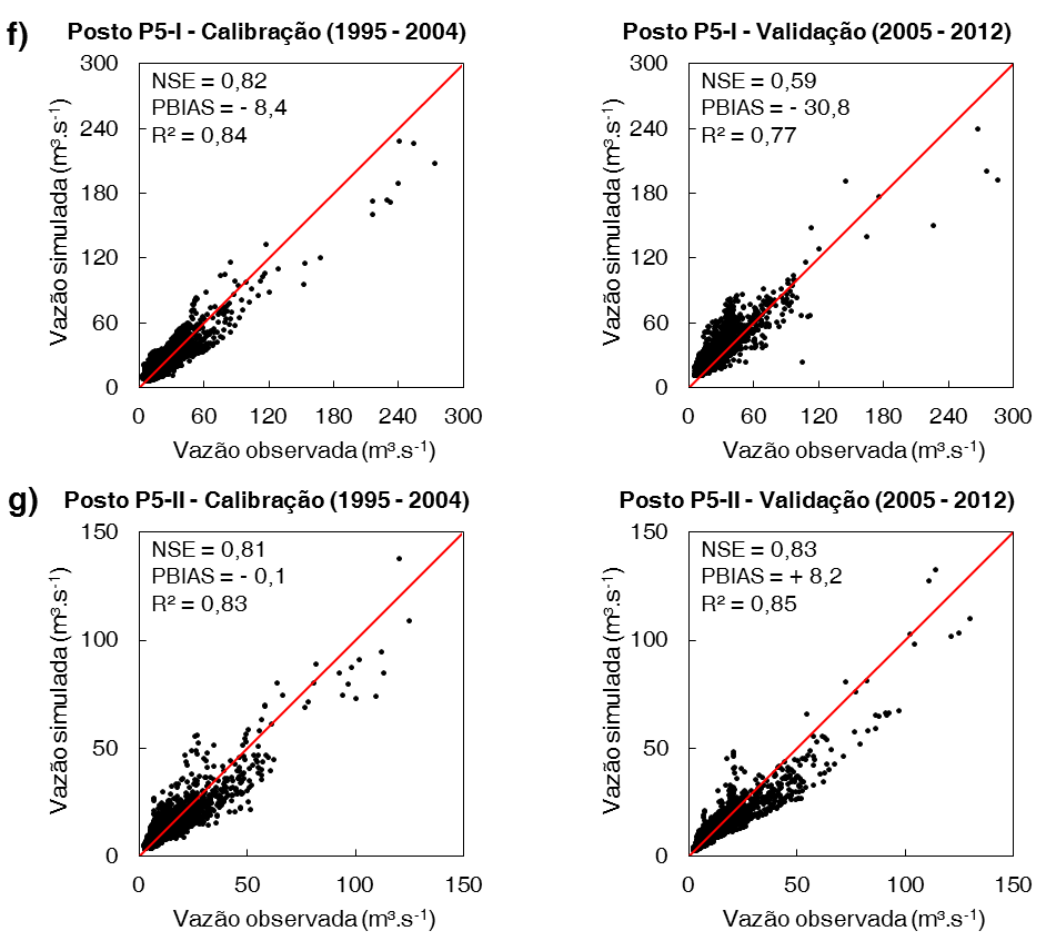

h) Posto P5-III - Calibração (1995 - 2004)

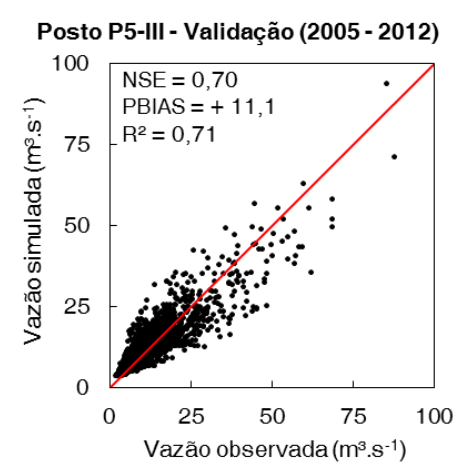

Figura 27 - Comparação entre a vazão diária observada e simulada nos períodos de calibração e validação nos postos: (a) P1, (b) P2, (c) P3, (d) P4-I, (e) P4-II, (f) P5-I, (g) P5-II e (h) P5-III.

inverso, com valores de NSE na validação superiores aos da calibração, a exemplo do posto P5-III na simulação mensal, conforme visto na Figura 26 (h), e o posto P5-II na simulação diária, conforme visto na Figura 27 (g). Nestes casos, a análise dos gráficos permite evidenciar que as vazões observadas durante o período de validação encontram-se dentro do intervalo de vazões observadas utilizadas no período de calibração.

Em relação ao PBIAS, a análise da Tabela 19 evidencia a predominância de valores negativos tanto no período de calibração quanto no período de validação, indicando a tendência de superestimativa dos valores simulados em relação aos valores observados. Tal comportamento é perceptível nos gráficos de dispersão apresentados, a exemplo da Figura 26 (b) no período de validação, onde a nuvem de pontos está predominantemente posicionada acima da reta 1:1. De maneira análoga, nos casos em que ocorre subestimativa dos valores 
simulados em relação aos observados, há o predomínio da nuvem de pontos abaixo da reta 1:1, conforme pode ser observado no período de validação da Figura 27 (g).

Verifica-se também que os valores percentuais de PBIAS do período de calibração apresentaram melhor desempenho do que o período de validação em várias bacias, sendo compatível com a tendência observada nos valores de NSE. Na calibração a faixa de PBIAS para as bacias variou entre $-20,1 \%$ a $+0,4 \%$ ("satisfatório" a "muito bom") na simulação mensal e entre $-21,5 \%$ a $-0,1 \%$ ("satisfatório" a "muito bom") na simulação diária. Já no período de validação a faixa de variação situou-se entre $-31,1 \%$ a $+8,4 \%$ ("insatisfatório" a "muito bom") na simulação mensal e entre -30,8\% a -5,5\% ("insatisfatório" a "muito bom") na simulação diária.

Outra informação relevante relacionada ao processo de calibração é a análise dos parâmetros selecionados quanto à sensibilidade, de modo a verificar quais componentes apresentaram maior influência nos resultados obtidos. Na Tabela 20 é apresentada a classificação, em formato de ranking, dos parâmetros utilizados na calibração em relação ao grau de importância no resultado obtido para cada uma das dez simulações realizadas. O ordenamento dos parâmetros na tabela foi estabelecido com base no valor-p médio de cada parâmetro nas simulações, o qual é indicativo da significância de sua sensibilidade. Quanto mais próximo de zero o valor-p de determinado parâmetro, maior a sensibilidade do mesmo no processo.

Através da análise da Tabela 20 verifica-se que o parâmetro de maior importância foi o CN2, configurando-se como o componente de maior sensibilidade em quatro das simulações (na simulação mensal das bacias B3 e B5 e na simulação diária das bacias B2 e B3). Tal parâmetro interfere diretamente na geração de escoamento superficial, estando fortemente relacionado aos valores extremos de vazão que se encontravam superestimados nas simulações não calibradas. $\mathrm{O}$ p-valor médio do $\mathrm{CN} 2$ das dez calibrações foi de 0,13 , o menor dentre todos os parâmetros, evidenciando a maior sensibilidade média dentre todos os parâmetros considerados.

O segundo parâmetro de maior relevância nas calibrações foi o SOL_K, apresentando um p-valor médio de 0,15 , seguido do parâmetro SOL_BD, com p-valor de 0,19. Tais parâmetros representam propriedades físico-hidráulicas do solo (condutividade hidráulica e densidade, respectivamente), influenciando os processos de escoamento superficial e percolação da água através do perfil. Outros parâmetros de relativa importância nas simulações foram ALPHA_BF e GW_DELAY, ambos relacionados ao movimento da água 
subterrânea, sendo que o primeiro regula o retorno da água do aquífero raso para o rio, enquanto o segundo atua na passagem da água do perfil de solo para o aquífero raso.

Tabela 20 - Ordenação dos parâmetros utilizados na calibração das cinco bacias em relação ao grau de importância.

\begin{tabular}{|c|c|c|c|c|c|c|c|c|c|c|c|}
\hline \multirow{3}{*}{ Parâmetro } & \multicolumn{10}{|c|}{ Posição dos parâmetros no ranking } & \multirow{3}{*}{$\begin{array}{l}\text { Valor-p } \\
\text { médio }\end{array}$} \\
\hline & \multicolumn{5}{|c|}{ Simulações mensais } & \multicolumn{5}{|c|}{ Simulações diárias } & \\
\hline & B1 & B2 & B3 & B4 & B5 & B1 & B2 & B3 & B4 & B5 & \\
\hline CN2.mgt & 2 & 5 & 1 & 2 & 1 & 11 & 1 & 1 & 5 & 13 & 0,13 \\
\hline SOL_K.sol & 4 & 1 & 5 & 16 & 5 & 7 & 6 & 7 & 1 & 3 & 0,15 \\
\hline SOL_BD.sol & 6 & 3 & 3 & 6 & 3 & 5 & 8 & 3 & 13 & 1 & 0,19 \\
\hline GW_DELAY.gw & 3 & 4 & 6 & 10 & 13 & 6 & 9 & 4 & 10 & 14 & 0,25 \\
\hline ALPHA_BF.gw & 1 & 9 & 11 & 11 & 8 & 9 & 11 & 10 & 4 & 6 & 0,30 \\
\hline ALPHA_BNK.rte & 8 & 10 & 9 & 8 & 6 & 3 & 13 & 8 & 11 & 7 & 0,31 \\
\hline CH_K2.rte & 11 & 11 & 7 & 12 & 11 & 2 & 7 & 6 & 12 & 11 & 0,35 \\
\hline GW_REVAP.gw & 7 & 7 & 8 & 1 & 10 & 14 & 10 & 12 & 2 & 8 & 0,38 \\
\hline SLSUBBSN.hru & - & 2 & - & 4 & 12 & 4 & 4 & - & 6 & 4 & 0,42 \\
\hline ESCO.hru & 9 & 12 & 4 & 13 & 14 & 10 & 16 & 5 & 7 & 9 & 0,44 \\
\hline GWQMN.gw & 5 & 6 & 10 & 3 & 4 & 13 & 15 & 11 & 15 & 12 & 0,48 \\
\hline SOL_AWC.sol & 12 & 13 & 2 & 17 & 7 & 12 & 3 & 9 & 3 & 15 & 0,49 \\
\hline CH_N2.rte & 10 & 8 & 12 & 15 & 15 & 1 & 14 & 2 & 14 & 5 & 0,49 \\
\hline LAT_TTIME.hru & - & - & - & 7 & 2 & - & 2 & - & 8 & 2 & 0,57 \\
\hline SURLAG.bsn & - & - & - & 14 & 9 & 8 & 12 & - & 9 & 10 & 0,65 \\
\hline CANMX.hru & - & - & - & - & - & - & 5 & - & - & - & 0,90 \\
\hline REVAPMN.gw & - & - & - & 9 & - & - & - & - & - & - & 0,92 \\
\hline
\end{tabular}

Observação: o sinal (-) indica que o parâmetro não foi incluído na calibração da referida simulação

Os parâmetros de maior sensibilidade detectados nas calibrações realizadas neste trabalho também têm sido apontados como de grande relevância por outros estudos. Andrade, Mello e Beskow (2011) realizaram simulações na Bacia do Ribeirão Jaguara, no sul de Minas Gerais, nas quais os dois parâmetros de maior sensibilidade foram CN2 e ALPHA_BF. No trabalho de Carvalho (2014), realizado na Bacia do Alto Rio Jardim, no Distrito Federal, o parâmetro CN2 foi o de maior sensibilidade, seguido pelo parâmetro SOL_K em segundo lugar e GW_DELAY em quarto. Villela (2015), em trabalho realizado na Bacia do Córrego Cana-do-Reino, em Votuporanga-SP, destacou os parâmetros CN2 e SOL_K em segundo e 
quarto lugar no ranking de sensibilidade. Na simulação realizada por Pereira (2013) na Bacia do Rio Pomba, localizada no sudeste de Minas Gerais e em parte do Rio de Janeiro, o ranking com os parâmetros de maior sensibilidade incluiu SOL_K em primeiro, ALPHA_BF em segundo e CN2 em quarto lugar. Já no trabalho de Silva (2016), em simulação realizada na Bacia do Rio Mariquitá, no nordeste do estado do Pará, o ranking de sensibilidade foi composto pelos parâmetros GW_DELAY em primeiro, ALPHA_BF em quarto e CN2 em quinto.

Ao realizar-se uma análise comparativa do desempenho na calibração e validação das bacias deste estudo, verifica-se que o melhor desempenho foi registrado no posto P5-II, na Bacia do Alto Rio Paranapanema. Em tal bacia, foram obtidos valores de NSE mensais de 0,92 e 0,88 na calibração e validação, enquanto nas simulações diárias os valores foram de 0,81 e 0,83 , respectivamente. Desse modo, segundo a classificação proposta por Moriasi et al. (2007), todas as simulações enquadram-se na categoria "muito bom". Já a simulação com os piores foi observada no posto P2, na Bacia do Ribeirão do Feijão, onde foram obtidos NSE mensais de 0,71 (“bom") e 0,62 (“satisfatório"), e NSE diários de 0,51 ("satisfatório") e 0,38 ("insatisfatório").

A título de comparação, na Tabela 21 são apresentados valores de NSE obtidos na calibração e validação da vazão em bacias hidrográficas situadas nas regiões sudeste e sul do Brasil, sendo também incluídas informações referentes aos períodos utilizados em cada uma destas etapas, bem como o passo de tempo simulado (mensal ou diário).

Tabela 21 - Valores de NSE obtidos em simulações de vazão com o SWAT em bacias das regiões sul e sudeste do Brasil.

\begin{tabular}{lcccc}
\hline \multicolumn{1}{c}{ Autor(es) } & $\begin{array}{c}\text { Nome da bacia e } \\
\text { localização }\end{array}$ & $\begin{array}{c}\text { Passo de } \\
\text { tempo }\end{array}$ & $\begin{array}{c}\text { NSE na } \\
\text { Calibração }\end{array}$ & $\begin{array}{c}\text { NSE na } \\
\text { Validação }\end{array}$ \\
\hline Villela (2015) & $\begin{array}{c}\text { Córrego Cana-do-Reino } \\
\text { (Votuporanga }- \text { SP) }\end{array}$ & Mensal & $\begin{array}{c}0,85 \\
(2004 \text { a 2010) }\end{array}$ & $\begin{array}{c}0,76 \\
(2011 \text { a 2014) }\end{array}$ \\
\hline Armas (2006) & $\begin{array}{c}\text { Rio Corumbataí } \\
\text { (Região de Piracicaba }- \text { SP) }\end{array}$ & Mensal & $\begin{array}{c}0,94 \\
(1973 \text { a 1984) })\end{array}$ & $\begin{array}{c}0,84 \\
(1985 \text { a 2003) }\end{array}$ \\
\hline $\begin{array}{l}\text { Barbarotto Junior } \\
(2014)\end{array}$ & $\begin{array}{c}\text { Rio Jundiaí } \\
\text { (Região de Jundiaí - SP) }\end{array}$ & Mensal & $\begin{array}{c}0,91 \\
(1976 \text { a 1983) }\end{array}$ & $\begin{array}{c}0,68 \\
(1984 \text { a 1994) }\end{array}$ \\
\hline $\begin{array}{l}\text { Gibertoni } \text { et al. } \\
(2009)\end{array}$ & $\begin{array}{c}\text { Rio Nhundiaquara } \\
\text { (Litoral do Paraná) }\end{array}$ & Mensal & $\begin{array}{c}0,81 \\
(1975 \text { a 1991) }\end{array}$ & $\begin{array}{c}0,74 \\
(1992 \text { a 2007) }\end{array}$ \\
\cline { 2 - 5 } & Diário & $\begin{array}{c}0,42 \\
(1975 \text { a 1991) }\end{array}$ & $\begin{array}{c}0,53 \\
(1992 \text { a 2007) }\end{array}$ \\
\hline $\begin{array}{l}\text { Andrade, Mello e } \\
\text { Beskow (2011) }\end{array}$ & $\begin{array}{c}\text { Ribeirão Jaguara } \\
\text { (Sul de Minas Gerais) }\end{array}$ & Diário & $\begin{array}{c}0,66 \\
(2006 \text { a 2008) }\end{array}$ & $\begin{array}{c}0,87 \\
(2008 \text { a 2009) }\end{array}$ \\
\hline
\end{tabular}




\begin{tabular}{lcccc}
\hline $\begin{array}{l}\text { Durães, Mello e } \\
\text { Naghettini (2011) }\end{array}$ & $\begin{array}{c}\text { Rio Paraopeba } \\
\text { (Sul de Minas Gerais) }\end{array}$ & Diário & $\begin{array}{c}0,79 \\
(1984 \text { a 1989) }\end{array}$ & $\begin{array}{c}0,79 \\
(2001 \text { a 2005) }\end{array}$ \\
\hline $\begin{array}{l}\text { Fukunaga } \text { et al. } \\
(2015)\end{array}$ & $\begin{array}{c}\text { Rio Itapemirim } \\
\text { (Sul do Espírito Santo) }\end{array}$ & Diário & $\begin{array}{c}0,75 \\
(1993 \text { a 1995) }\end{array}$ & $\begin{array}{c}0,67 \\
(1996 \text { a 2000) }\end{array}$ \\
\hline $\begin{array}{l}\text { Rodrigues } \text { et al. } \\
(2015)\end{array}$ & $\begin{array}{c}\text { Rio Pará } \\
\text { (Centro-sul de Minas Gerais) }\end{array}$ & Diário & $\begin{array}{c}0,75 \\
(1980 \text { a 1996) }\end{array}$ & $\begin{array}{c}0,79 \\
(1997 \text { a 2012) }\end{array}$ \\
\hline $\begin{array}{l}\text { Pereira } \text { et al. } \\
(2014)\end{array}$ & $\begin{array}{c}\text { Córrego do Galo } \\
\text { (Sul do Espírito Santo) }\end{array}$ & Diário & $\begin{array}{c}0,65 \\
(1995 \text { a 2000) }\end{array}$ & $\begin{array}{c}0,70 \\
(2001 \text { a 2013) }\end{array}$ \\
\hline
\end{tabular}

Apesar de algumas simulações apresentarem resultados insatisfatórios neste trabalho, considera-se que, no geral, os resultados aqui obtidos encontram-se dentro das faixas de valores usualmente descritas pela literatura brasileira, conforme pode ser observado nos valores exibidos na Tabela 21. Em determinadas bacias do estudo, a exemplo da bacia B3 Ribeirão Mandaguari e B5 - Alto Paranapanema, os resultados foram superiores a diversas das estatísticas relatadas na literatura nacional.

De modo geral, considera-se que os bons resultados obtidos neste trabalho são atribuídos aos esforços no aperfeiçoamento da modelagem na etapa pré-calibração, na qual realizou-se o ajuste dos componentes hidrológicos, em especial da evapotranspiração, de forma a obter valores compatíveis com os valores tipicamente esperados para as bacias analisadas. Dessa maneira, a realização do procedimento de calibração a partir de uma simulação onde as distorções hidrológicas estivessem previamente minimizadas possibilitou que fossem atingidos bons resultados sem a necessidade de alteração excessiva dos parâmetros originais do modelo, evidenciando uma parametrização ainda coerente com as características das bacias. 


\section{CONCLUSÕES E RECOMENDAÇÕES}

Visando aprimorar a simulação hidrológica do modelo SWAT em bacias de regiões tropicais, foram propostas neste trabalho alterações nas rotinas de simulação e ajustes de determinados parâmetros e configurações do modelo. As modificações realizadas compreenderam três linhas de procedimento principais: 1) a alteração do código fonte do SWAT de forma a desativar o mecanismo de dormência das plantas, o qual é originalmente acionado através de um limiar de duração do fotoperíodo; 2) ajustes nos cronogramas das operações de manejo das culturas e 3) modificação de parâmetros do banco de dados de crescimento vegetal, os quais, apesar de já apresentarem valores pré-estabelecidos, podem ser editados conforme a necessidade do usuário. De modo a avaliar a influência destas modificações nas respostas do modelo, foram realizadas simulações em cinco bacias hidrográficas situadas no estado de São Paulo, com áreas variando entre 42 e 5959 km².

As modificações propostas resultaram na alteração das curvas de desenvolvimento do índice de área foliar (IAF) dos usos da terra das bacias, antes estimadas de forma inadequada pelo modelo tanto em termos de magnitude quanto de sazonalidade. Tal ajuste permitiu que processos como a intercepção de água pelo dossel das plantas e a transpiração vegetal passassem a ser simulados de forma coerente, os quais por sua vez alteraram a evapotranspiração e outros componentes do balanço hídrico.

Em todas as bacias analisadas no estudo, as estimativas anuais dos componentes do balanço hídrico obtidas após as modificações do modelo passaram a apresentar valores mais próximos do que seria usualmente esperado nestes locais, principalmente quando comparadas aos valores obtidos com as configurações originais do modelo. A evapotranspiração foi o componente hidrológico mais impactado com as modificações propostas, apresentando um aumento médio de $61 \%$ nas simulações. Os novos valores mostraram grande aderência com estimativas anuais de evapotranspiração obtidas através de métodos empíricos, bem como foram próximos aos resultados obtidos experimentalmente em outros trabalhos.

Ao comparar-se as vazões simuladas pela versão modificada do SWAT com as vazões obtidas pela versão padrão do modelo, mesmo sem calibração, verificou-se uma melhoria significativa do ajuste em relação aos dados observados. A alteração do índice de área foliar e da evapotranspiração nas bacias ocasionou uma redução das parcelas de escoamento 
superficial e do fluxo subterrâneo, contribuindo na redução dos valores extremos de vazão, antes superestimados em até $300 \%$ em alguns postos fluviométricos.

$\mathrm{Na}$ última etapa do trabalho, as simulações obtidas a partir do SWAT modificado foram submetidas ao procedimento de calibração e validação em relação à vazão. Na maioria das bacias obteve-se estatísticas de precisão que permitiram classificar o desempenho do modelo como "bom" e "muito bom", sendo também verificadas estatísticas satisfatórias no período de validação. Ademais, a calibração a partir de um modelo no qual as distorções dos processos hidrológicos da bacia estivessem previamente minimizadas permitiu que o ajuste entre dados observados e simulados fosse alcançado sem alteração excessiva dos parâmetros, resultando em valores calibrados representativos das condições da bacia.

Conforme salientado, nas cinco bacias utilizadas como estudos de caso neste trabalho - mesmo com uma diferença significativa de extensão entre as mesmas - os procedimentos mostraram-se adequados para obtenção de uma configuração melhor representativa do balanço hidrológico, o que resultou em simulações de vazão de bom desempenho. Tal fato é um forte indicador que os procedimentos aqui propostos podem ser aplicados a outras áreas, bem como estendidos para outras condições.

As modificações no SWAT propostas no presente estudo tiveram como objetivo a obtenção de uma modelagem hidrológica mais consistente e melhor representativa da realidade, sendo ao final avaliada em relação à simulação de vazão. Entretanto, são ainda necessários estudos adicionais visando investigar como os outros componentes simulados pelo modelo - a exemplo da produção de sedimentos, agroquímicos e qualidade da água comportam-se em relação às modificações aqui propostas, visto que estes são fortemente influenciados por processos como a geração de escoamento superficial.

O presente trabalho evidenciou também a necessidade de revisão de determinadas rotinas de simulação do modelo visando uma melhor representação de processos relacionados ao ciclo hidrológico das bacias estudadas. De modo análogo, considera-se de fundamental importância que tal procedimento seja estendido aos outros módulos de simulação do SWAT, com o intuito de verificar se as rotinas relacionadas aos outros componentes simulados são de fato aplicáveis às condições locais. Conforme apontado anteriormente, são exemplos de processos que ainda requerem adaptações a simulação do crescimento de florestas e áreas de vegetação nativa e o estabelecimento de cronogramas de operações de manejo adequados para as demais culturas perenes e de estação fria.

Além das imprecisões relacionadas às rotinas de simulação inadequadas para representação de determinados processos físicos nas bacias, parâmetros não representativos da 
realidade também geram grandes incertezas na modelagem. Nesse sentido, são necessários esforços voltados à obtenção e compilação de parâmetros adequados à aplicação do SWAT em bacias brasileiras, de forma a disponibilizar um banco de dados nacional ou mesmo regional para tais aplicações. Trabalhos nesse sentido já vêm sendo realizados, a exemplo de Lima et al. (2013), que objetiva a geração de valores de referência para aplicações do SWAT no Bioma Cerrado. Além disso, também é evidente a necessidade de se estabelecer critérios gerais para a parametrização correta na etapa de calibração de simulações realizadas em bacias brasileiras, de modo a obter resultados fisicamente justificáveis e representativos da realidade. 


\section{REFERÊNCIAS}

ABBASPOUR, K. C. et al. Modelling hydrology and water quality in the pre-alpine/alpine Thur watershed using SWAT. Journal of Hydrology, v. 333, p. 413-430, 2007.

ABOUKHALED, A.; ALFARO, A.; SMITH, M. Lysimeters. Rome: FAO, 1982. 68 p.

ADEOGUN, G. A. et al. Validation of SWAT Model for Prediction of Water Yield and Water Balance: Case Study of Upstream Catchment of Jebba Dam in Nigeria. International Journal of Mathematical, Computational, Physical, Electrical and Computer Engineering, v. 8, n. 2, p. 264-270, 2014.

AGÊNCIA NACIONAL DE ÁGUAS - ANA. Evolução da rede hidrometeorológica nacional. Brasília: ANA, 2007. 15 p.

Conjuntura dos recursos hídricos no Brasil: 2013. Brasília: ANA, 2013. 432 p.

ALLEN, R. G. et al. Crop evapotranspiration: Guidelines for computing crop water requirements. FAO Irrigation and Drainage Paper $N^{\circ}$ 56. Rome: FAO, 1998. 300 p.

ALLEN, R. G.; SMITH, M.; PERRIER, A. An update for the definition of reference evapotranspiration. ICID BULLETIN, v. 43, n. 2, p. 1-34, 1994.

ALMEIDA, A. C.; SOARES, J. V. Comparação entre uso de água em plantações de Eucalyptus grandis e floresta ombrófila densa (Mata Atlântica) na costa leste do Brasil. Rev. Árvore, Viçosa, v. 27, n. 2, p. 159-170, 2003.

ALMEIDA, F. F. M. Fundamentos Geológicos do Relevo Paulista. São Paulo: Instituto de Geografia, Universidade de São Paulo, 1964. 99 p.

ALVES SOBRINHO, T.; FERREIRA, P. A.; PRUSKI, F. F. Desenvolvimento de um infiltrômetro de aspersão portátil. Rev. Bras. Eng. Agríc. Ambient., Campina Grande, v. 6, n. 2, p. 337-344, 2002.

AMERICAN SOCIETY FOR TESTING MATERIALS - ASTM. Standard Practice for Evaluating Environmental Fate Models of Chemicals. Philadelphia: ASTM, 1984.

ANDRADE, M. A.; MELLO, C. R.; BESKOW, S. Simulação hidrológica em uma bacia hidrográfica representativa dos Latossolos na região Alto Rio Grande, MG. Rev. Bras. Eng. Agríc. Ambient., Campina Grande, v. 17, n. 1, p. 69-76, 2013.

ARMAS, E. D. Biogeodinâmica de herbicidas utilizados em cana-de-açúcar Saccharum spp na sub-bacia do rio Corumbataí. 2006. 186 p. Tese (Doutorado em Ecologia de Agroecossistemas) - Escola Superior de Agricultura Luiz de Queiroz, Universidade de São Paulo, Piracicaba, 2006. 
ARNOLD, J. G. et al. SWAT Input/Output Documentation Version 2012. College Station: Texas Water Resources Institute, 2012a.

ARNOLD, J. G. et al. SWAT: Model use, calibration, and validation. Transactions of the ASABE, v. 55, n. 4, p. 1491-1508, 2012 b.

ARNOLD, J. G. et al. Large Area Hydrologic Modeling and Assessment - Part I: Model Development. J. American Water Resour. Assoc, v. 34, n. 1, p. 73-89, 1998.

ARNOLD, J. G. et al. Water resources of the Texas gulf basin. Water Sci. Tech, v. 39, n. 3, p. 121-133, 1999.

ARROIO JUNIOR, P. P. Avaliação da produção e transporte de sedimentos na bacia hidrográfica do Rio Itaqueri, municípios de Itirapina e Brotas - SP. 2013. 112 p. Dissertação (Mestrado em Ciências da Engenharia Ambiental) - Escola de Engenharia de São Carlos, Universidade de São Paulo, São Carlos, 2013.

ARROIO JUNIOR, P. P.; MAUAD, F. F. Simulação dos Impactos das Mudanças Climáticas na Vazão da Bacia do Ribeirão do Feijão - SP. Revista Brasileira de Recursos Hídricos, v. 20, n. 3, p. 741-751, 2015.

ATKINSON, T. C. Techniques for measuring subsurface flow on hillslopes. In: KIRKBY, M. J. (Ed.). Hillslope hydrology. Chichester: John Wilwy, 1978. p. 73-120.

BARBAROTTO JUNIOR, J. L. Análise da disponibilidade hídrica da bacia do rio Jundiaí por meio de simulações hidrológicas de cenários prováveis. 2014. 188 p. Dissertação (Mestrado em Engnharia Civil) - Faculdade de Engenharia Civil, Arquitetura e Urbanismo, Universidade Estadual de Campinas, Campinas, 2014.

BARBIERI, V.; VILLA NOVA, N. A. Climatologia e a cana-de-açúcar. In: (Ed.). Climatologia. Araras: PLANALSUCAR - Coordenadoria Regional Sul - COSUL, 1977.

BARRETO, C. E. A. G. Balanço hídrico em zona de afloramento do sistema aquífero guarani a partir de monitoramento hidrogeológico em bacia representativa. 2006. 173 p. Dissertação (Mestrado em Hidráulica e Saneamento) - Escola de Engenharia de São Carlos, Universidade de São Paulo, São Carlos, 2006.

BARRETO, C. E. A. G.; WENDLAND, E.; MARCUZZO, F. F. N. Estimativa da evapotranspiração a partir de variação de nível estático de aquífero. Eng. Agríc., Jaboticabal, v. 29, n. 1, p. 52-61, 2009.

BARROS, C. A. P. et al. Estimativa da infiltração de água no solo na escala de bacia hidrográfica. Rev. Bras. Ciênc. Solo, Viçosa, v. 38, n. 2, p. 557-564, 2014.

BEASLEY, D. B.; HUGGINS, L. F.; MONKE, E. J. ANSWERS: a model for watershed planning. Transactions of the ASAE, v. 23, n. 4, p. 938-944, 1980.

BEGOU, J. C. et al. Multi-Site Validation of the SWAT Model on the Bani Catchment: Model Performance and Predictive Uncertainty. Water, v. 8, n. 178, 2016. 
BERnARDO, S.; SOARES, A. A.; MANTOVANI, E. C. Manual de irrigação. 8 ed. Viçosa: UFV, 2006. 625 p.

BERTONI, J. C.; TUCCI, C. E. M. Precipitação. In: TUCCI, C. E. M. (Ed.). Hidrologia: Ciência e Aplicação. 4 ed. Porto Alegre: ABRH, 2009. cap. 5, p. 177-231.

BEVEN, K. J.; KIRKBY, M. J. A Physically Based Variable Contributing Area Model of Basin Hydrology. Hydrological Sciences Bulletin, v. 24, n. 1, p. 43-69, 1979.

BIAN, L. et al. An integrated interface system to couple the SWAT model and ARC/INFO. In: CONFERENCE/WORKSHOP ON INTEGRATING GIS AND ENVIRONMENTAL MODELING, 3, 1996, Santa Fé. Proceedings... Santa Fe, 1996. p. 21-25.

BIESBROUCK, B. et al. AVSWAT 2000. Leuven: Catholic University of Leuven, Laboratory for Soil and Water Management (LSWM), 2002.

BINGNER, R. L.; THEURER, F. D. AnnAGNPS Technical Processes. Version 3.2. Oxford: USDA-ARS/USDA-NRCS, 2005. 84 p.

BLANEY, H. F.; CRIDDLE, W. D. Determining water requirements in irrigated areas from climatological data. Technical Publication No. 96. Washington: Soil Conservation Service, 1950.

BONUMÁ, N. B. Modelagem do Escoamento, da Produção de Sedimentos e da Transferência de Fósforo em Bacia Rural no Sul do Brasil. 2011. 136 p. Tese (Doutorado em Ciência do Solo) - Universidade Federal de Santa Maria, Santa Maria, 2011.

BONUMÁ, N. B. et al. Estimativa do balanço hídrico de uma bacia hidrográfica com o modelo SWAT. In: SIMPÓSIO BRASILEIRO DE RECURSOS HÍDRICOS, XX, 2013, Bento Gonçalves. Anais... Bento Gonçalves: ABRH, 2013.

BORAH, D. K.; BERA, M. Watershed-scale hydrologic and nonpoint-source pollution models: Review of mathematical bases. Transactions of the ASAE, v. 46, n. 6, p. 15531566, 2003.

BOURAOUI, F. et al. Application of the SWAT model on the Medjerda River basin (Tunisia). Phys. Chem. Earth, v. 30, n. 8 - 10, p. 497-507, 2005.

BRANDÃO, V. S.; PRUSKI, F. F.; SILVA, D. D. Infiltração da água no Solo. 2 ed. Viçosa: Editora UFV, 2003. 98 p.

BREDA, A. Avaliação de melhorias para um sistema de previsão hidrológica horária. 2008. Dissertação (Mestrado em Engenharia de Recursos Hídricos e Ambiental) - Setor de Tecnologia, Universidade Federal do Paraná, Curitiba, 2008.

BRESSIANI, D. A. et al. Review of Soil and Water Assessment Tool (SWAT) applications in Brazil: Challenges and prospects. Int J Agric \& Biol Eng, v. 8, n. 3, p. 9 - 35, 2015. 
BRIGHENTI, T. M.; BONUMÁ, N. B.; CHAFFE, P. L. B. Calibração hierárquica do modelo SWAT em uma bacia hidrográfica Catarinense. Revista Brasileira de Recursos Hídricos, v. 21, n. 1, p. 53-64, 2016.

BRITO, F. B. et al. Sustentabilidade Hídrica da Sub-Bacia do Rio Sangradouro, Sergipe. Revista Brasileira de Geografia Física, v. 7, n. 1, p. 155-164, 2014.

BRUNT, D. Physical and dynamical meteorology. 2 ed. Cambridge: University Press, 1952.

BRUTSAERT, W. Comments on surface roughness parameters and the height of dense vegetation. Journal of the Meteorological Society of Japan, v. 53, p. 96-97, 1975.

CABRAL, O. M. R. et al. The energy and water balance of a Eucalyptus plantation in southeast Brazil. Journal of Hydrology, v. 388, n. 3, p. 208-216, 2010.

CAIADO, M. A. C. Modeling fate and transport of nitrogen and phosphorus in crop fields under tropical conditions. 2005. 197 p. Tese (Doutorado em Biological Systems Engineering) - Faculty of the Virginia Polytechnic Institute and State University, Blacksburg, 2005.

CÂMARA, C. D.; LIMA, W. P. Corte raso de uma plantação de Eucalyptus saligna de 50 anos: impactos sobre o balanço hídrico e a qualidade da água em uma microbacia experimental. Scientia Forestalis, v. 56, p. 41-58, 1999.

CAMArgo, A. P. Balanço hídrico no estado de São Paulo. Boletim n. 116. 3 ed. Campinas: IAC, 1971. 24 p.

CAMARGO, A. P.; CAMARGO, M. B. P. Uma revisão analítica da evapotranspiração potencial. Bragantia, Campinas, v. 59, n. 2, p. 125-137, 2000.

CAMBOIM, S. et al. Mapeamento sistemático: A base para as infraestruturas nacionais de dados espaciais. In: SIMPÓSIO BRASILEIRO DE CIÊNCIAS GEODÉSICAS E TECNOLOGIAS DA GEOINFORMAÇÃO, II, 2008, Recife. Anais ... Recife: UFPE, 2008.

CARVALHO, F. H. Uso do modelo SWAT na estimativa da vazão e da produção de sedimentos em bacia agrícola do Cerrado brasileiro. 2014. 154 p. Dissertação (Mestrado em Agronomia) - Faculdade de Agronomia e Medicina Veterinária, Universidade de Brasília, Brasília, 2014.

CARVALHO, L. G. et al. Evapotranspiração de referência: uma abordagem atual de diferentes métodos de estimativa. Pesq. Agropec. Trop., Goiânia, v. 41, n. 3, p. 456-465, 2011.

CAStAny, G. Traité Pratique Des Eaux Souterraines. Paris: Editora Dunod, 1967. 661 p.

CASTRO, K. B. Avaliação do modelo SWAT na simulação da vazão em bacia agrícola do Cerrado intensamente monitorada. 2013. 141 p. Dissertação (Mestrado em Geociências) - Universidade de Brasília, Brasília, 2013. 
CECÍLIO, R. A. et al. Modelagem da infiltração de água no solo sob condições de estratificação utilizando-se a equação de Green-Ampt. Rev. Bras. Eng. Agríc. Ambient., v. 7, n. 3, p. 415-422, 2003.

CERUCCI, M.; CONRAD, J. M. The use of binary optimization and hydrologic models to form riparian buffers. J. American Water Resour. Assoc, v. 39, n. 5, p. 1167-1180, 2003.

CHAPLOT, V. Impact of DEM mesh size and soil map scale on SWAT runoff, sediment, and NO3-N loads predictions. Journal of Hydrology, v. 312, p. 207-222, 2005.

Impact of spatial input data resolution on hydrological and erosion modeling: Recommendations from a global assessment. Physics and Chemistry of the Earth, v. 67-69, p. 23-35, 2014.

CHOW, V. T.; MAIDMENT, D. R.; MAYS, L. W. Applied hydrology. New York: McGraw-Hill, Inc., 1988.

CICCO, V. Determinação da evapotranspiração pelos métodos dos balanços hídrico e de cloreto e a quantificação da interceptação das chuvas na Mata Atlântica: São Paulo, SP e Cunha, SP. 2009. 138 p. Tese (Doutorado em Geografia Física) - Faculdade de Filosofia, Letras e Ciências Humanas, Universidade de São Paulo, São Paulo, 2009.

COELHO, R. D.; MIRANDA, J. H.; DUARTE, S. N. Infiltração da água no solo: parte I infiltrômetro de anéis versus infiltrômetro de aspersores. Rev. Bras. Eng. Agríc. Ambient., Campina Grande, v. 4, n. 2, p. 137-141, 2000.

COLLISCHONN, W.; TASSI, R. Introduzindo hidrologia. Porto Alegre: IPH UFRGS, 2008. 149 p.

COMITÊ DA BACIA HIDROGRÁFICA DO ALTO PARANAPANEMA - CBH-ALPA. Relatório de Situação dos Recursos Hídricos das Bacias Hidrográficas do Estado de São Paulo. Bacia Hidrográfica do Alto Paranapanema - UGRHI 14. Ano base 2012. Piraju: CBHALPA, 2013. 25 p.

CONFESOR JR, R. B.; WHITTAKER, G. W. Automatic Calibration of Hydrologic Models With Multi-Objective Evolutionary Algorithm and Pareto Optimization. J. American Water Resour. Assoc, v. 43, n. 4, p. 981-989, 2007.

CORREIA, F. W. S. et al. Balanço de umidade na Amazônia e sua sensibilidade às mudanças na cobertura vegetal. Cienc. Cult., São Paulo, v. 59, n. 3, 2007.

COSTA, F. M. Análise por métodos hidrológicos e hidroquímicos de fatores condicionantes do potencial hídrico de bacias hidrográficas - Estudo de casos no Quadrilátero Ferrífero - MG. 2005. 147 p. Dissertação (Mestrado em em Ciências Naturais) - Universidade Federal de Ouro Preto, Ouro Preto, 2005.

CRUZ, F. A. Instalação e calibração de lisímetro de pesagem e determinação da evapotranspiração de referência para a região de Seropédica - RJ. 2005. 79 p. Dissertação (Mestrado em Fitotecnia) - Universidade Federal Rural do Rio de Janeiro, Seropédica, 2005. 
CUNHA, A. T. Estimativa experimental da taxa de recarga na zona de afloramento do Aquífero Guarani, para a região de São Paulo - SP. 2003. 117 p. Dissertação (Mestrado em Hidráulica e Saneamento) - Escola de Engenharia de São Carlos, Universidade de São Paulo, São Carlos, 2003.

DANIEL, E. B. et al. Watershed Modeling and its Applications: A State-of-the-Art Review. The Open Hydrology Journal, v. 5, p. 26-50, 2011.

DE VRIES, J. J.; SIMMERS, I. Groundwater recharge: an overview of processes and challenges. Hydrogeology Journal, v. 10, p. 5-17, 2002.

DHAMI, S. R.; PANDEY, A. Comparative review of recently developed hydrologic models. J. Indian Water Resour. Soc., v. 33, n. 3, p. 34-42, 2013.

DOMENICO, P. A.; SCHWARTZ, F. W. Physical and Chemical Hydrogeology. Singapore: John Wiley \& Sons, 1990.

DOORENBOS, J.; PRUITT, W. O. Guidelines for predicting crop water requirements. FAO Irrigation and Drainage Paper $N^{\circ} 24.2$ ed. Rome: FAO, 1977.

DUFFIE, J. A.; BECKMAN, W. A. Solar engineering of thermal processes. New York: Wiley, 1980.

DURAES, M. F.; MELLO, C. R.; NAGHETTINI, M. Applicability of the swat model for hydrologic simulation in Paraopeba River basin, MG. CERNE, Lavras, v. 17, n. 4, p. 481488, 2011.

EMÍDIO, Z. P. O. Impacto do balanço hídrico em diferentes tipos de solo: comparação entre dados de radar-pluviômetro e análise de tendência da chuva média em área agrícola. 2008. 147 p. Tese (Doutorado em Geociências) - Instituto de Geociências e Ciências Exatas, Universidade Estadual Paulista, Rio Claro, 2008.

EMPRESA BRASILEIRA DE PESQUISA AGROPECUÁRIA - EMBRAPA; SECRETARIA DA AGRICULTURA E ABASTECIMENTO (SÃO PAULO); INSTITUTO AGRONÔMICO DE CAMPINAS - IAC. Levantamento pedológico semi-detalhado do Estado de São Paulo. Quadrícula de São Carlos, Folha SF 23-Y-A-I. Campinas: IAC, 1981. Escala 1:100.000.

EMPRESA BRASILEIRA DE PESQUISA AGROPECUÁRIA - EMBRAPA. Serviço Nacional de Levantamento e Conservação de Solos. In: REUNIÃO TÉCNICA DE LEVANTAMENTO DE SOLOS, 10, 1979, Rio de Janeiro. Súmula.... Rio de Janeiro, 1979. p. 83.

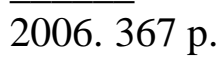

Sistema Brasileiro de Classificação de Solos. 2 ed. Rio de Janeiro: Embrapa Solos,

FAN, F. M.; COLLISCHONN, W. Integração do Modelo MGB-IPH com Sistema de Informação Geográfica. Revista Brasileira de Recursos Hídricos, v. 19, n. 1, p. 243-254, 2014. 
FARAMARZI, M. et al. Modelling blue and green water resources availability in Iran. Hydrological Processes, v. 23, n. 2, p. 486-501, 2008.

FETTER, C. W. Applied Hydrogeology. 2 ed. Oshkosh: Merrill Publishing Company, University of Wisconsin, 1988. $592 \mathrm{p}$.

FRANCHINI, M. et al. Physical interpretation and sensitivity analysis of TOPMODEL. Journal of Hydrology, Amsterdam, v. 175, p. 293-338, 1996.

FREIRE, C. C.; OMENA, S. P. F. Princípios de hidrologia ambiental. Curso de Aproveitamento em Gestão de Recursos Hídricos: modalidade à distância. 2013. 203 p.

FREVERT, D. R.; HILL, R. W.; BRAATEN, B. C. Estimation of FAO evapotranspiration coefficients. Journal of Irrigation and Drainage Engineering, New York, v. 109, n. 2, p. 265-270, 1983.

FUKUNAGA, D. C. et al. Application of the SWAT hydrologic model to a tropical watershed at Brazil. CATENA, v. 125, p. 206-213, 2015.

GARBOSSA, L. H. P. et al. The use and results of the Soil and Water Assessment Tool in Brazil: A review from 1999 until 2010. In: INTERNATIONAL SWAT CONFERENCE \& WORKSHOPS, 2011, Toledo. Proceedings ... Toledo: Texas A\&M University, 2011.

GASSMAN, P. W. et al. The soil and water assessment tool: historical development, applications, and future research directions. Transactions of the ASABE, v. 50, p. 12111250, 2007.

GAYATHRI, K. D.; GANASRI, B. P.; DWARAKISH, G. S. A Review on Hydrological Models. Aquatic Procedia, v. 4, p. 1001-1007, 2015.

GHAFFARI, G. The Impact of DEM Resolution on Runoff and Sediment Modelling Results. Research Journal of Environmental Sciences, v. 5, p. 691-702, 2011.

GIBERTONI, R. F. C. et al. Modelagem da produção e transporte de sedimentos em bacias hidrográficas do litoral paranaense: o caso da bacia do Rio Nhundiaquara. In: SIMPÓSIO BRASILEIRO DE RECURSOS HÍDRICOS, XVIII, 2009, Campo Grande. Anais... Campo Grande: ABRH, 2009.

GOSAIN, A. K. et al. Return-flow assessment for irrigation command in the Palleru River basin using SWAT model. Hydrol. Process., v. 19, n. 3, p. 673-682, 2005.

GREEN, C. H. et al. Hydrologic evaluation of the Soil and Water Assessment Tool for a large tile-drained watershed in Iowa. Transactions of the ASABE, v. 49, n. 2, p. 413-422, 2006.

GREEN, W. H.; AMPT, G. Studies of soil physics.Part I. The flow ofwater and air though soils. Journal of Agronomy Science, London, v. 4, p. 1-24, 1911. 
GU, R. R.; SAHU, M. K.; JHA, M. K. Simulating the impacts of bio-fuel crop production on nonpoint source pollution in the Upper Mississippi River Basin. Ecological Engineering, v. 74, p. 223-229, 2015.

GUPTA, H. V.; SOROOSHIAN, S.; YAPO, P. O. Status of automatic calibration for hydrologic models: Comparison with multilevel expert calibration. Journal of Hydrologic Engineering, v. 4, n. 2, p. 135-143, 1999.

HARGREAVES, G. H.; HARGREAVES, G. L.; RILEY, J. P. Agricultural benefits for Senegal River Basin. Journal of Irrigation and Drainage Engineering, v. 111, n. 2, p. 113124, 1985.

HARRISON, L. P. Fundamental concepts and definitions relating to humidity. In: WEXLER, A. (Ed.). Humidity and moisture. New York: Reinhold Publishing Company, v. 3, 1963.

HILLEL, D.; KRENTOS, V. D.; STYLIANOU, Y. Procedure and test of an internal drainage method for measuring soil hydraulic characteristics in situ. Soil Science, v. 114, p. 395-400, 1972.

HIRSCH, R. M.; FISHER, G. T. Past, Present, and Future of Water Data Delivery from the U.S. Geological Survey. Journal of Contemporary Water Research \& Education, v. 153, n. 1, p. 4-15, 2014.

HOLTON, H. N. A concept for infiltration estimation in watershed Engineering. USDA ARS Bull, v. 25, p. 41-51, 1961.

HORTON, R. E. An approach toward a physical interpretation - capacity. Soil Science Society of America Proceeding, Madison, v. 5, p. 399-417, 1940.

HOWELL, T. A.; SCHNEIDER, A. D.; JENSEN, M. E. History of lysimeter desing and use for evapotranspiration. Lysimeter for evapotrans piration and enviroment measurements. New York: ASCE, 1991. 1- 19 p.

HUNSAKER, D. J. et al. Estimating cotton evapotranspiration crop coefficients with a multispectral vegetation index. Irrigation Science, v. 22, n. 2, p. 95-104, 2003.

INSTITUTO DE PESQUISAS TECNOLÓGICAS - IPT. Mapa geomorfológico do Estado de São Paulo. São Paulo: IPT, 1981. Escala 1:1.000.000.

JAYAKRISHNAN, R. et al. Advances in the application of the SWAT model for water resources management. Hydrol. Process., v. 19, p. 749-762, 2005.

JENSEN, M. E.; BURMAN, R. D.; ALLEN, R. G. Evapotranspiration and irrigation water requirements. ASCE Manuals and Reports on Engineering Practice ${ }^{\circ} 70$. New York: ASCE, 1990.

KALIN, L.; HANTUSH, M. H. Hydrologic modeling of an eastern Pennsylvania watershed with NEXRAD and rain gauge data. Journal of Hydrologic Engineering, v. 11, n. 6, p. 555$569,2006$. 
KAUFFMAN, S. P. et al. Green Water Credits - exploring its potential to enhance ecosystem services by reducing soil erosion in the Upper Tana basin, Kenya. Int. J. Biodivers. Sci. Ecosyst. Serv. Manag, p. 1-11, 2014.

KELLER FILHO, T.; ZULLO JUNIOR, J.; LIMA, P. R. S. Análise da transição entre os dias secos e chuvosos por meio da cadeia Markov de terceira ordem. Pesquisa Agropecuária Brasileira, v. 41, n. 9, p. 1341-1349, 2006.

KINZELBACH, W. A Survey of Methods for Groundwater Recharge in Arid and SemiArid Regions. Early Warning and Assessment Report Series, UNEP/DEWA/RS.02/2. Nairobe: United Nations Environment Programme, 2002.

KNISEL, W. G. CREAMS, a field scale model for chemicals, runoff and erosion from agricultural management systems. USDA Conservation Research Rept. No. 26. USDA, 1980.

KOSTIAKOV, A. N. On the dynamics of the coefficient of water-percolation in soils and on the necessity for studying in from a dynamic point of view for purposes of amelioration. International Soil Science Society, Paris, p. 17-21, 1932.

KRISTENSEN, K.; JENSEN, S. A model of estimating actual evapotranspiration from potential evapotranspiration. Nordic Hydrology, v. 6, p. 170-188, 1975.

LAPPONI, C. J. Estatística usando Excel. Rio de Janeiro: Elsevier, 2005. 393-418 p.

LELIS, T. A. et al. Análise de sensibilidade e calibração do modelo SWAT aplicado em bacia hidrográfica da região sudeste do Brasil. Rev. Bras. Ciênc. Solo, Viçosa, v. 36, n. 2, p. 623-634, 2012.

LEMON, E. R.; GLASER, A. H.; SATTERWHITE, L. E. Some aspects of the relationship of soil, plant and meteorological factors to evapotranspiration. Soil Science Society of America Proceeding, Madison, v. 21, n. 5, p. 464-468, 1957.

LEONARD, R. A.; KNISEL, W. G.; STILL, D. A. GLEAMS: Groundwater loading effects on agricultural management systems. Transactions of the ASAE, v. 30, n. 5, p. 1403-1428, 1987.

LÉVESQUE, E. et al. Evaluation of streamflow simulation by SWAT model for two small watersheds under snowmelt and rainfall. Hydrological Sciences Journal, v. 53, n. 5, p. 961976, 2008.

LIMA, J. E. F. W. Modelagem numérica do fluxo da água no solo e do escoamento de base em uma bacia experimental em área agrícola no cerrado. 2010. 312 p. Tese (Doutorado em Tecnologia Ambiental e Recursos Hídricos) - Universidade de Brasília, Brasília, 2010.

LIMA, J. E. F. W. et al. Desenvolvimento de base de dados de solos para aplicação do modelo SWAT em bacia do Bioma Cerrado. In: SIMPÓSIO BRASILEIRO DE RECURSOS HÍDRICOS, 20, 2013, Bento Gonçalves. Água, desenvolvimento econômico e socioambiental. Bento Gonçalves: Associação Brasileira de Recursos Hídricos, 2014. 
LIMA, W. P. Impacto Ambiental do Eucalipto. 2 ed. São Paulo: Editora da Universidade de São Paulo, 1996. 301 p.

Hidrologia florestal aplicada ao manejo de bacias hidrográficas. Piracicaba: Escola Superior de Agricultura "Luiz de Queiroz", 2008. 253 p.

LIN, S. et al. Effect of DEM resolution on SWAT outputs of runoff, sediment and nutrients. Hydrol. Earth Syst. Sci. Discuss., v. 7, p. 4411-4435, 2010.

LOMBARDI NETO, F. et al. Nova abordagem para cálculo de espaçamento entre terraços. In: SIMPÓSIO SOBRE TERRACEAMENTO AGRÍCOLA, 1988, Campinas. Anais... Campinas: Fundação Cargill, 1989. p. 99-124.

LUCAS, A. A. T. Impactos da irrigação sobre a qualidade da água da microbacia hidrográfica do Ribeirão dos Marins. In: MOUTINHO, P. e PINTO, R. P. (Ed.). Ambiente complexo, propostas e perspectivas socioambientais. São Paulo: Contexto, v. 1, 2009. p. 103-118.

MAMO, K. H. M.; JAIN, M. K. Runoff and Sediment Modeling Using SWAT in Gumera Catchment, Ethiopia Open Journal of Modern Hydrology, v. 3, p. 196-205, 2013.

MAREK, G. W. et al. Estimating evapotranspiration for dryland cropping systems in the semiarid texas high plains using SWAT. J. American Water Resour. Assoc, v. 52, n. 2, p. 298-314, 2016.

MARINHO FILHO, G. M. et al. Modelos hidrológicos: conceitos e aplicabilidades. Revista de Ciências Ambientais, v. 6, n. 2, p. 35-47, 2012.

MAZIERO, T. A.; WENDLAND, E. Variabilidade espacial da recarga em área urbana. Revista Brasileira de Recursos Hídricos v. 13, p. 35-46, 2008.

MEDEIROS, A. T. Estimativa da evapotranspiração de referência a partir da equação de Penman-Monteith, de medidas lisimétricas e de equações empíricas em Paraipaba, CE. 2002. 103 p. Tese (Doutorado em Agronomia) - Escola Superior de Agricultura "Luiz de Queiroz", Universidade de São Paulo, Piracicaba, 2002.

MELO, J. G. et al. Fatores condicionantes na recarga do aquifero Açu na borda sudoeste na Bacia Potiguar, RN. Águas Subterrâneas, v. 19, p. 105-122, 2005.

MELO NETO, J. O. Análise de sensibilidade escalar do modelo hidrológico SWAT. 2012. 149 p. Dissertação (Mestrado em Recursos Hídricos) - Universidade Federal de Lavras, Lavras, 2013.

MONTEITH, J. L. Evaporation and environment. In: SYMPOSIUM OF THE SOCIETY FOR EXPERIMENTAL BIOLOGY, XIX, 1965, Swansea. The State and Movement of Water in Living Organisms. New York: Cambridge University Press, 1965. p. 205-234. 
MORIASI, D. N. et al. Model Evaluation Guidelines for Systematic Quantification of Accuracy in Watershed Simulations. Transactions of the ASABE, v. 50, n. 3, p. 885-900 2007.

MORO, M. A utilização da interface SWAT-SIG no estudo da produção de sedimentos e do volume de escoamento superficial com simulação de cenários alternativos. 2005. 100 p. Dissertação (Mestrado em Agronomia) - Escola Superior de Agricultura Luiz de Queiroz, Universidade de São Paulo, Piracicaba, 2005.

MOUNIER F et al. Radar-guided control and interpolation of rain gauge precipitation data over France. EURO4M Publications, 2012. 49 p.

MURRAY, F. W. On the computation of saturation vapor pressure. Journal of Applied Meteorology, v. 6, p. 203-204, 1967.

NASH, J. E.; SUTCLIFF, J. River flow forecasting through conceptual models. Journal of Hydrology, v. 10, n. 3, p. 282-290, 1970.

NASSIF, D. S. P. Evapotranspiração, transpiração e trocas gasosas em canavial irrigado. 2014. 123 p. Tese (Doutorado em Ciências) - Escola Superior de Agricultura Luiz de Queiroz, Universidade de São Paulo, Piracicaba, 2015.

NEITSCH, S. L. et al. Soil and Water Assessment Tool. Theoretical Documentation Version 2009. College Station: Texas Water Resources Institute, 2011. 618 p.

NETTO, G. J. S. Desempenho de modelos de infiltração na sub-bacia do Ribeirão Marcela - Região do Alto Rio Grande - MG. 2011. 75 p. Dissertação (Mestrado em Engenharia Agrícola) - Universidade Federal de Lavras, Lavras, 2011.

NOBREGA, R. L. B. et al. Identifying hydrological responses of micro-catchments under contrasting land use in the Brazilian Cerrado. Hydrol. Earth Syst. Sci. Discuss., v. 12, p. 9915-9975, 2015.

OLIVEIRA, J. B. et al. Mapa pedológico do Estado de São Paulo: legenda expandida. Campinas: Instituto Agronômico/EMBRAPA Solos, 1999.

OLIVEIRA, J. B.; PRADO, H. Levantamento pedológico semidetalhado do Estado de São Paulo. Quadrícula de São Carlos. Memorial descritivo. Campinas: IAC, 1984. 110 p.

OLIVEIRA, M. C. T. Processos erosivos e preservação de áreas de risco de erosão por voçorocas. In: GUERRA, A. J. T.;SILVA, A. S., et al (Ed.). Erosão e Conservação dos Solos. Rio de Janeiro: Bertrand Brasil, 1999. p. 57-99.

OLIVEIRA, P. T. S. et al. Trends in water balance components across the Brazilian Cerrado. Water Resources Research, v. 50, p. 7100-7114, 2014.

OLIVEIRA, R. A. et al. Área foliar em três cultivares de cana-de-açúcar e sua correlação com a produção de biomassa. Pesquisa Agropecuária Tropical, v. 37, n. 2, p. 71-76, 2007. 
OVERTON, D. E. Mathematical refinement of an infiltration equation for watershed engineering. Agricultural Research Service USDA, 1965. 11 p.

OVERTON, D. E. Muskingum flood routing of upland streamflow. Journal of Hydrology, v. 4, p. 185-200, 1966.

PAIVA, E. M. C. D. Métodos de estimativa da produção de sedimentos em pequenas bacias hidrográficas. In: PAIVA, J. B. D. e PAIVA, E. M. C. D. (Ed.). Hidrologia aplicada à gestão de pequenas bacias hidrográficas. Porto Alegre: ABRH, 2003. p. 628.

PARAJULI, P. B.; MANKIN, K. R.; BARNES, P. L. Applicability of targeting vegetative filter strips to abate fecal bacteria and sediment yield using SWAT. Agricultural Water Management, v. 95, p. 1189-1200, 2008.

PENMAN, H. L. Natural evaporation from open water, bare soil, and grass. Proceedings of the Royal Society, London, v. 193, n. 1, p. 120-146, 1948.

PERAZZOLI, M.; PINHEIRO, A.; KAUFMANN, V. Assessing the impact of climate change scenarios on water resources in southern Brazil. Hydrological Sciences Journal, v. 58, n. 1, p. 77-87, 2013.

PEREIRA, A. R.; VILLA NOVA, N. A.; SEDIYAMA, R. Evapotranspiração. Piracicaba: FEALQ/ESALQ/USP, 1997. 70 p.

PEREIRA, D. R. Simulação hidrológica na bacia hidrográfica do rio Pomba usando o modelo SWAT. 2013. 126 p. Tese (Doutorado em Engenharia Agrícola) - Universidade Federal de Viçosa, Viçosa, 2013.

PEREIRA, D. R. et al. Impacts of deforestation on water balance components of a watershed on the Brazilian East Coast. Rev. Bras. Ciênc. Solo, v. 38, p. 1350-1358, 2014.

PERRIN DE BRICHAMBAUT, C. Estimation des resources energetiques solaires en France. Paris: Editions Européennes Thermique et Industrie, 1975.

PerrotTA, M. M. et al. Mapa Geológico do Estado de São Paulo. São Paulo: CPRM, 2005. Escala 1:750.000.

PHILIP, J. R. The theory of Infiltration: 5. The Influence of the Initial Moisture Content. Soil Science, v. 4, n. 84, p. 329-339, 1957.

PLATE, E. J. Aerodynamic characteristics of atmospheric boundary layers. Oak Ridge: U.S. Atomic Energy Comm., 1971. 190 p.

PORTO, F. A.; BRANCO, S. M.; LUCA, S. J. Caracterização da qualidade da água. In: PORTO, R. L. (Ed.). Hidrologia ambiental. São Paulo: EDUSP, 1991. p. 27-65.

PRADO, H.; JORGE, J. A.; MENK, J. R. F. Levantamento pedológico detalhado e caracterização fisico-hídrica dos solos da Estação Experimental de Agronomia de Votuporanga (SP). Boletim Científico, 42. Campinas: IAC, 1999. 24 p. 
PRIESTLEY, C. H. B.; TAYLOR, R. J. On the assessment of surface heat flux and evaporation using large-scale parameters. Mon. Weather. Rev., v. 100, p. 81-92, 1972.

PRUITT, W. O.; ANGUS, D. E. Large weighing lysimeter for measuring evapotranspiration. Transactions of the ASAE, v. 3, n. 2, p. 13- 15, 1960.

PRUSKI, F. F.; BRANDÃO, V. S.; SILVA, D. D. Escoamento superficial. Viçosa: UFV, 2003. 88 p.

RENNÓ, C. D.; SOARES, J. V. Modelos hidrológicos para gestão Ambiental. São José dos Campos: Instituto Nacional de Pesquisas Espaciais, 2000.

RICHARDS, L. A. Capillary conduction of liquids through porous materials. Physics and Chemistry of the Earth, v. 1, p. 318-333, 1931.

RICHARDS, P. L. et al. The Oak Orchard Soil Water Assessment Tool - A decision support system for watershed management. Part 1. Calibration and validation. Brockport: State University of New York, 2010. 34 p.

RIGHETTO, A. M. Hidrologia e recursos hídricos. São Carlos: EESC/USP, 1998. 840 p.

RITCHIE, J. T. Model for predicting evaporation from a row crop with incomplete cover. Water Resources Research, v. 8, p. 1204-1213, 1972.

ROCHA, E. O. et al. The Contribution of Conservation Practices in Reducing Runoff, Soil Loss, and Transport of Nutrients at theWatershed Level. Water Resources Management, v. 26, n. 13, p. 3831-3852, 2012.

RODRIGUES, E. L. et al. Impact of changes in land use in the flow of the Pará River Basin, MG. Rev. Bras. Eng. Agríc. Ambient., v. 19, n. 1, p. 70-76, 2015.

ROLIM, G. S. et al. Classificação climática de Köppen e de Thornthwaite e sua aplicabilidade na determinação de zonas agroclimáticas para o Estado de São Paulo. Bragantia, v. 66, p. 711-720, 2007.

ROO, A. P. J.; HAZEIHOFF, L.; BURROUGH, P. A. Soil erosion modelling using 'ANSWERS' and Geographical Information Systems. Earth Surface Processes and Landforms, v. 14, p. 517-532, 1989.

ROUHOLAHNEJAD, E. et al. A parallelization framework for calibration of hydrological models. Environ. Model. Software, v. 31, p. 28-36, 2012.

RYKIEL JR, E. J. Testing ecological models: the meaning of validation. Ecological Modelling, v. 90, p. 229-244, 1996.

SALEMI, L. Balanço de água e de nitrogênio em uma microbacia coberta por pastagem no litoral norte do Estado de São Paulo. 2009. 86 p. Dissertação (Mestrado em Ecologia Aplicada) - Escola Superior de Agricultura Luiz de Queiroz, Piracicaba, 2009. 
SANCHES, L. et al. Índice de área foliar em floresta de transição amazonia cerrado em diferentes médotos de estimativa. Ciência e Natura, v. 30, n. 1, p. 57-69, 2008.

SANT'ANNA NETO, J. L. Decálogo da climatologia do sudeste brasileiro. Revista Brasileira de Climatologia, Rio de Janeiro, v. 1, p. 43-60, 2005.

SANTHI, C. et al. A modeling approach to evaluate the impacts of water quality management plans implemented in a watershed in Texas. Environ. Model. Software, v. 21, n. 8, p. 1141-1157, 2006.

SANTOS, I. et al. Hidrometria aplicada. Curitiba: Instituto de Tecnologia para o Desenvolvimento, 2001. $172 \mathrm{p}$.

SANTOS, J. T. S. Aplicação do modelo hidrológico SWAT para a sub-bacia do Rio Arapepó (Salinópolis/PA) 2014. 84 p. Dissertação (Mestrado em Ciências Florestais) Universidade Federal Rural da Amazônia, Belém, 2014.

SANTOS, M. L.; SANTOS, H. G. The state of the art of brazilian soil mapping and prospects for digital soil mapping. Developments in Soil Science, v. 31, 2007.

SAXTON, K. E.; RAWLS, W. J. Soil water characteristic estimates by texture and organic matter for hydrologic solutions. Soil Science Society of America Journal, Madison, v. 70, p. 1569-1578, 2006.

SCHERRER, S. et al. Formation of runoff at the hillslope scale during intense precipitation. Hydrol. Earth Syst. Sci., v. 11, p. 907-922, 2007.

SCHLADOW, S. G.; CLARK, J. F. Use of tracers to quantify subsurface flow through a mining pit. Ecol Appl., v. 18, n. 8, p. 55-71, 2008.

SEDIYAMA, G. C. Estimativa da evapotranspiração: histórico, evolução e análise crítica. Revista Brasileira de Agrometeorologia, Santa Maria, v. 4, n. 1, p. 1-12, 1996.

SENTELHAS, P. C. Estimativa diária da evapotranspiração de referência com dados de estação meteorológica convencional e automática. 1998. 97 p. Tese (Doutorado em Agronomia) - Escola Superior de Agricultura "Luiz de Queiroz", Universidade de São Paulo, Piracicaba, 1998.

SHARPLEY, A. N.; WILLIAMS, J. R. EPIC - Erosion productivity impact calculator. 1. Model documentation. Washington: USDA, Agricultural Research Service, 1990. 145 p.

SILVA, A. K. L. Impacto da expansão da palma de óleo sobre o escoamento superficial e produção de sedimentos nas sub-bacias hidrográficas não monitoradas dos rios Bujaru e Mariquita no nordeste do estado do Pará, Amazônia Oriental. 2016. 287 p. Tese (Doutorado em Ciências da Engenharia Ambiental) - Escola de Engenharia de São Carlos, Universidade de São Paulo, São Carlos, 2016.

SILVA, J. M. O serviço ambiental hidrológico das áreas de proteção permanente: um estudo de caso com modelagem numérica em pequena e mesoescala na bacia do Rio 
Piracicaba. 2013. 99 p. Tese (Doutorado em Ciências Atmosféricas) - Universidade de São Paulo, São Paulo, 2013.

SILVA, R. V.; KOBIYAMA, M. TOPMODEL: teoria integrada e revisão. Ra'e Ga, Curitiba, n. 14, p. 97-110, 2007.

SILVEIRA, A. L. L. Ciclo hidrológico e a bacia hidrográfica. In: TUCCI, C. E. M. (Ed.). Hidrologia: Ciência e Aplicação. 4 ed. Porto Alegre: ABRH, 2009. cap. 2, p. 35-40.

SINGH, V. P.; FIORENTINO, M. Geographical Information Systems in Hydrology. London: Kluwer Academic Publishers, 1996. 445 p.

SINGH, V. P.; WOOLHISER, D. A. Mathematical Modeling of Watershed Hydrology. Journal of Hydrological Engineering, v. 7, n. 4, p. 270-292, 2002.

SLOAN, P. G. et al. Modeling surface and subsurface stormflow on steeply-sloping forested watersheds. Report 142. Lexington: Water Resources Inst, 1983.

SMEDEMA, L. K.; RYCROFT, D. W. Land drainage: planning and design of agricultural drainage systems. New York: Cornell University Press, 1983.

SOUSA, A. M. L. Estimativa dos fluxos de calor a partir de imagens orbitais e aplicação na modelagem hidrológica. 2010. 128 p. Tese (Doutorado em Recursos Hídricos e Saneamento Ambiental) - Universidade Federal do Rio Grande do Sul, Porto Alegre, 2010.

SOUSA, A. M. L. et al. Evapotranspiration from Remote Sensing to Improve the Swat Model in Eastern Amazonia. Revista Floresta e Ambiente, v. 22, n. 4, p. 456-464, 2015.

STOCKLE, C. O. et al. A method for estimating the direct and climatic effects of rising atmospheric carbon dioxide on growth and yield of crops: Part 1 - Modification of the EPIC model for climate change analysis. Agricultural Systems, v. 38, p. 225-238, 1992.

STRAUCH, M. et al. The impact of Best Management Practices on simulated streamflow and sediment load in a Central Brazilian catchment. Journal of Environmental Management, v. 127 (Suppl), p. 24-36, 2013.

STRAUCH, M.; VOLK, M. SWAT plant growth modification for improved modeling of perennial vegetation in the tropics. Ecological Modelling, v. 269, p. 98-112, 2013.

STRICKER, H.; BRUTSAERT, W. Actual evapotranspiration over summer period in the 'Hupsel Catchment.'. Journal of Hydrology, v. 39, p. 139-157, 1978.

TETENS, O. Uber einige meteorologische Begriffe. Z. Geophys., v. 6, p. 297-309, 1930.

THORNTHWAITE, C. W. An approach towards a rational classification of climate. Geographycal Review, London, v. 38, n. 1, p. 55-94, 1948.

TIM, U. S. Emerging technologies for hydrologic and water quality modeling research. Transactions of the ASAE, v. 39, n. 20, p. 465-476, 1996. 
TODINI, E. The ARNO rainfall - runoff model. Journal of Hydrology, v. 175, n. 293-338, 1996.

TRIPATHI, M. P.; RAGHUWANSHI, N. S.; RAO, G. P. Effect of watershed subdivision on simulation of water balance components. Hydrol. Process., v. 20, n. 5, p. 1137-1156, 2006.

TROVATI, L. R.; ANTÔNIO, M. A. A influência da variabilidade e a incerteza na medida da chuva por radar e pluviômetro na água disponível no solo. In: SIMPÓSIO BRASILEIRO DE SENSORIAMENTO REMOTO, 13, 2007, Florianópolis. Anais ... Florianópolis: INPE, 2007. p. 5035-5042.

TSOU, M. S.; WHITTEMOREZ, D. O. User Interface for Ground-water Modeling: ArcView Extension. Journal of Hydrologic Engineering, v. 6, n. 3, p. 251-257, 2001.

TUCCI, C. E. M. Modelos Hidrológicos. Porto Alegre: Editora da Universidade Federal do Rio Grande do Sul - ABRH, 2005. 669 p.

. Hidrologia: Ciência e Aplicação. 4 ed. Porto Alegre: ABRH, 2009. 655 p.

TUCCI, C. E. M.; COLLISCHONN, W. Simulação Hidrológica de grandes Bacias. Revista Brasileira de Recursos Hídricos, v. 6, n. 1, p. 95-118, 2001.

U.S. DEPARTMENT OF COMMERCE - USDC. NATIONAL OCEANIC AND ATMOSPHERIC ADMINISTRATION - NOAA. Precipitation-Frequency Atlas of the United States. Vols. 1 - 9. Silver Spring: NOAA, 2013.

UNITED STATES DEPARTMENT OF AGRICULTURE - USDA. Urban hydrology for small watersheds. Department of Agriculture, Natural Resources Conservation Service, Engineering Division, Technical Release 55. Washington: USDA, 1986.

UNITED STATES DEPARTMENT OF AGRICULTURE - USDA; SOIL CONSERVATION SERVICE - SCS. National Engineering Handbook. Section

4 Hydrology, Chapters 4-10. 1972.

VAN DIJK, A. I. J. M.; BRUIJNZEEL, L. A. Modelling rainfall interception by vegetation of variable density using an updated analytical model. Part 1. Model description. Journal of Hydrology, v. 247, p. 230-238, 2001.

VAN GRIENSVEN, A.; MAHARJAN, S.; ALEMAYEHU, T. Improved simulation of evapotranspiration for land use and climate change impact analysis at catchment scale. In: INTERNATIONAL CONGRESS ON ENVIRONMENTAL MODELLING AND SOFTWARE, 7, 2014, San Diego. Proceedings... San Diego: iEMSs, 2014.

VAN GRIENSVEN, A. et al. Critical review of SWAT applications in the upper Nile basin countries. Hydrol. Earth Syst. Sci., v. 16, p. 3371-3381, 2012.

VAN LIEW, M. W.; ARNOLD, J. G.; BOSCH, D. D. Problems and potential of autocalibrating a hydrologic model. Transactions of the ASABE, v. 48, n. 3, p. 1025-1040, 2005 . 
VAN LIEW, M. W.; FENG, S.; PATHAK, T. B. Climate change impacts on streamflow, water quality, and best management practices for the Shell and Logan Creek watersheds in Nebraska. Intl. J. Agric. and Biol. Eng, v. 5, n. 1, p. 13-34, 2012.

VAN LIEW, M. W. et al. Suitability of SWAT for the conservation effects assessment project: A comparison on USDA-ARS experimental watersheds. Journal of Hydrologic Engineering, v. 12, n. 2, p. 173-189, 2007.

VAN LOON, A.; DROOGERS, P. Soil and Water Assessment Tool, Kitui - Kenya. WatManSup Report No 3. Wageningen: FutureWater, 2007. 67 p.

VAZQUEZ-AMABILE, G. G.; ENGEL, B. A.; FLANAGAN, D. C. Modeling and risk analysis of nonpoint-source pollution caused by atrazine using SWAT. Transactions of the ASABE, v. 49, n. 3, p. 667-678, 2006.

VEIGA, A. M. Calibração do modelo hidrossedimentológico SWAT na bacia hidrográfica do córrego Samambaia, Goiânia - GO. 2014. 131 p. Dissertação (Mestrado em Engenharia do Meio Ambiente) - Universidade Federal de Goiás, Goiânia, 2014.

VILLELA, J. M. Avaliação da influência da expansão da cana-de-açúcar no regime hidrossedimentológico na microbacia do córrego Cana do Reino, Votuporanga - SP. 2015. 132 p. Dissertação (Mestrado em Ciências da Engenharia Ambiental) - Escola de Engenharia de São Carlos, Universidade de São Paulo, São Carlos, 2015.

WAGNER, P. D. et al. Hydrological Modeling with SWAT in a Monsoon-Driven Environment: Experience from the Western Ghats, India. Transactions of the ASABE, v. 54, n. 5, p. 1783-1790, 2011.

WAHNFRIED, I.; HIRATA, R. Comparação dos métodos de estimativa de recarga de aquíferos em uma planície aluvionar na bacia hidrográfica do Alto Tietê (São Paulo). Revista Brasileira de Recursos Hídricos, Porto Alegre, v. 10, n. 1, p. 15-25, 2005.

WANG, X.; MELESSE, A. M. Effects of STATSGO and SSURGO as inputs on SWAT model's snowmelt simulation. J. American Water Resour. Assoc, v. 42, n. 5, p. 1217-1236, 2006.

WELLEN, C. et al. Quantifying the uncertainty of nonpoint source attribution in distributed water quality models: A Bayesian assessment of SWAT's sediment export predictions. Journal of Hydrology, v. 519, p. 3353-3368, 2014.

WILLIAMS, J. R. Flood routing with variable travel time or variable storage coefficients. Transactions of the ASAE, v. 12, n. 1, p. 100-103, 1969.

WILliAMS, J. R. The EPIC model. In: SINGH, V. P. (Ed.). Computer models of watershed hydrology. Littleton: Water Resources Publications, 1995. p. 909-1000.

WILLIAMS, J. R.; JONES, C. A.; DYKE, P. T. A modeling approach to determining the relationship between erosion and soil productivity. Transactions of the ASAE, v. 27, n. 1, p. 129-144, 1984. 
WILLIAMS, J. R.; NICKS, A. D.; ARNOLD, J. G. Simulator for water resources in rural basins. Journal of Hydraulic Engineering v. 111, n. 6, p. 970-986, 1985.

WINCHELL, M. et al. ArcSWAT Interface for SWAT 2012: User's guide. Temple: Texas A\&M AgriLife Research/USDA Agricultural Research Service, 2013. 464 p.

WORLD METEOROLOGICAL ORGANIZATION - WMO. Guide to Meteorological Instruments and Methods of Observation. No. 8. Geneva: Chairperson, Publications Board, 2008. $681 \mathrm{p}$.

WU, Y.; CHEN, J. Modeling of soil erosion and sediment transport in the East River Basin in southern China. Sci. Total Environ., v. 441, p. 159-168, 2012.

YAPO, P.; GUPTA, H. V.; SOROOSHIA, S. Calibration of conceptual rainfall-runoff models: Sensitivity to calibration data. Journal of Hydrology, v. 181, p. 23-48, 1996.

YOUNG, R. A. et al. AGNPS A nonpoint-source pollution model for evaluating agricultural watersheds. Journal of Soil \& Water Conservation, v. 44, n. 2, p. 168-173, 1989.

YUAN, Y. et al. AnnAGNPS Model Application for Nitrogen Loading Assessment for the Future Midwest Landscape Study. Water, v. 2, n. 1, 2010.

ZENG, R.; CAI, X. Analyzing streamflow changes: irrigation-enhanced interaction between aquifer and streamflow in the Republican River basin. Hydrol. Earth Syst. Sci., v. 18, p. 493-502, 2014. 


\section{ANEXO I - Modificação das rotinas de dormência no código fonte do SWAT}

subroutine dormant

! 
use parm

rea1 : : resnew

integer : : $j$

! ! by zhang

real :: BLG1, BLG2, BLG3, CLG, sf

real :: sol_min_n, resnew_n, resnew_ne

real : LMF, LSF, LSLF, LSNF, LMNF

orgc_f $=0$.

$B L G 1=0$.

$\mathrm{BLG2}=0$.

$B L G 3=0$.

$C L G=0$.

sf $=0$.

sol_min_n $=0$.

resnew $=0$.

resnew_n $=0$.

resnew_ne $=0$.

$\mathrm{LMF}=\overline{0}$.

LSF $=0$.

LSLF $=0$.

LSNF $=0$

LMNF $=0$.

! ! by zhang

$\begin{aligned} j & =0 \\ j & =i \mathrm{hru}\end{aligned}$

1! check for beginning of dormant season

if $($ idc $(i d p l t(j))==1$. or . idc $(i d p l t(j))==4)$ return

$\&^{\text {if }}($ idorm $(j)==0$. and. $\operatorname{day} 1(j)-\operatorname{dormhr}(j)<\operatorname{day} 1 \mathrm{mn}(\operatorname{hru} u \operatorname{sub}(j))$ )

select case (idc(idplt (j)))

!! make sure all operations are scheduled during growing season of warm season annual case $(1,4)$

dorm_flag = 1

cal1 operatn

end select

if (imgt $==1$ ) then

write $(143,1000)$ subnum $(j), \operatorname{hruno}(j), i y r, i \_m o, i i d a$,

hru_km(j),

cpnm(idplt $(j))$, "START-DORM", phubase $(j), \operatorname{phuacc}(j)$,

sol_sw( $j)$, bio_ms $(j)$, sol_rsd $(1, j)$, sol_sumno3 $(j)$,

sol sumsolp $(j)$

end if

!! check if end of dormant period

\&

if $\left(i \operatorname{dor} m(j)==1\right.$. and. $\operatorname{day} 1(j)-\operatorname{dormhr}(j)>=\operatorname{day} 1 \mathrm{mn}\left(\operatorname{hru}{ }_{-} \operatorname{sub}(j)\right)$ )

select case $(i d c(i d p l t(j)))$

!! end of perennial dormant period

case $(3,6,7)$

idorm $(j)=0$

!! end of cool season annual dormant period

case $(2,5)$

idorm $(j)=0$

phuacc $(j)=0$

end select

if (imgt $==1$ ) then

write $(143,1000)$ subnum(j), $\operatorname{hruno}(j), i y r, i \_m o, i j d a$,

hru_km(j)

cpnm(idplt(j)), "END-DORM", phubase(j), phuacc(j),

sol_sw $(j)$, bio_ms $(j)$, sol_rsd $(1, j)$, sol_sumno3 $(j)$,

sol_sumsolp ( $j$ ) end if

end if

1000 format (a5,1x,a4,3i6,1x, e10.5,1x,2a15,7f10.2)

return

end 